\title{
Portulacaceae through Caryophyllaceae of New York State
}

RICIIARD S. MITCIIELL

New York State Museum

Contributions to a Flora of New York State XI

Richard S. Mitchell, Editor

1993

BULLETIN NO. 486

N E W YORK STATE M U S E U M

The University of the State of New York

THE STATE EDUCATION DEPARTMENT

Albany, New York 12230 


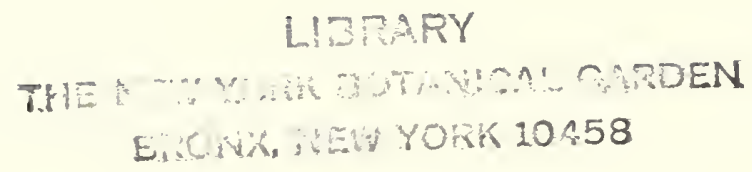




\section{Portulacaceae through Caryophyllaceae of New York State}

RICIIARD S. MITCIIELL

New York State Museum

Contributions to a Flora of New York State XI

Richard S. Mitchell, Editor

1993

BULLETIN NO. 486

N E W YORK S TA T E M U S E U M

The University of the State of New York

THE STATE EDUCATION DEPARTMENT

Albany, New York 12230 


\section{THE UNIVERSITY OF THE STATE OF NEW YORK}

\section{Regents of The University}

R. Carlos Carballada, Chancellor, B.S.

Rochester

Jorge L. BATISTA, Vice Chancellor, B.A., J.D.

Bronx

Willard A. Genrich, Chancellor Emeritus, LL.B.

Buffalo

EMLYN I. GRIFFITH, A.B., J.D.

Rome

Laura Bradley Chodos, B.A., M.A.

Rexford

Louise P. Matteoni, B.A., M.A., Ph.D.

Bayside

J. EDWARD MEYER, B.A., LL.B.

Armonk

FLOYD S. LiNTON, A.B., M.A., M.P.A.

Miller Place

Mimi LeVIN Lieber, B.A., M.A. New York

Shirley C. Brown, B.A., M.A., Ph.D. Albany

NORMA GLUCK, B.A., M.S.W. New York

Adelaide L. SANFord, B.A., M.A., P.D. Hollis

Walter CoOper, B.A., Ph.D. Rochester

CARL T. HAYDEN, A.B., J.D. Elmira

Diane O'Nelll MCGivern, B.S.N., M.A., Ph.D. Staten Island

SAUl B. COHEN, B.A., M.A., Ph.D New Rochelle

James C. DAwson, A.A., B.A., M.S., Ph.D. Peru

President of The University and Commissioner of Education

THOMAS SOBOL

Executive Deputy Commissioner of Education

THOMAS E. SHELDON

Deputy Commissioner for Cultural Education

Carole F. Huxley

Assistant Commissioner for the State Museum

LOUIS D. LEVINE

Chair, Biological Survey

Clifford A. Siegfried

State Botanist

RiCHARD S. MiTCHELL

The State Education Department does not discriminate on the basis of age, color, religion, creed, disability, marital status, veteran status, national origin, race, gender or sexual orientation in the educational programs and activities which it operates. Portions of this publication can be made available in a variety of formats, including braille, large print or audio tape, upon request. Inquiries concerning this policy of equal opportunity and affirmative action should be referred to the Department's Affirmative Action Officer, NYS Education Department, 89 Washington Avenue, Albany, NY 12234. 


\section{PREFACE}

OUR GOAL in producing this series is to present a useful and authoritative account of the plants of New York State. These contributions are intended to reflect the knowledge and taxonomic opinions of specialists who prepare the manuscripts while following a generalized format for consistency. Inclusion of ecological, distributional, medical and economic information on each species is also one of our major aims. Habitat references, flowering times, pertinent synonymy, etc., often apply specifically to New York plants rather than to the entire species. Illustration of all species should facilitate identification of specimens for those who are not formally trained in botany. Descriptions are original, ordered and as complete as possible to provide sequential cross-referencing.

Distribution maps accompany species of seed plants, ferns, mosses, lichens and some groups of fungi. These are plotted by counties to avoid pinpointing endangered habitats, while offering an accurate visual picture of past collecting. Maps are based on the master file at the New York State Museum, Albany, and supplemented by available data (specimens examined by the authors) from herbaria housing significant New York collections. Data or literature citations for any map may be obtained, on approval, from the Museum. We hope that these bulletins will serve individuals with interest in the flora, as well as to provide information for State and Federal agencies, conservation organizations, industry and the scientific community. With these works go our hopes for preservation and wise use of a precious and lifegiving resource--our State's plant life.

\section{The New York State Flora Committee}

The steering council of the New York State Flora Committee met for the first time on January 19, 1976, and established as its goals the promotion of study of the State's plant resources and the publication of this series of museum bulletins. These contributions will be continually updated after publication for possible incorporation into larger volumes at a later date.

Members of the council at the time of this publication are:

Richard S. Mitchell, Chairman, State Botanist, N. Y. State Museum, Albany (Vascular Plants)

Charles J. Sheviak, Curator of Botany, N. Y. State Museum, Albany (Vascular Plants)

Norton G. Miller, Chief Scientist, N. Y. State Museum, Albany (Bryophytes)

Clark T. Rogerson, The New York Botanical Garden, Bronx (Fungi)

George J. Schumacher, Biology Dept. SUNY, Binghamton (Algae)

Gordon C. Tucker, N. Y. State Muscum, Albany (Vascular Plants) 


\section{CONTENTS}

Preface $\ldots \ldots \ldots \ldots \ldots \ldots \ldots \ldots \ldots \ldots \ldots \ldots \ldots \ldots \ldots \ldots \ldots \ldots \ldots \ldots$ iii

The New York State Flora Committee $\ldots \ldots \ldots \ldots \ldots \ldots \ldots \ldots \ldots \ldots \ldots \ldots \ldots \ldots$ iii

Acknowledgments $\ldots \ldots \ldots \ldots \ldots \ldots \ldots \ldots \ldots \ldots \ldots \ldots \ldots \ldots \ldots \ldots \ldots \ldots \ldots \ldots$

Important Note $\ldots \ldots \ldots \ldots \ldots \ldots \ldots \ldots \ldots \ldots \ldots \ldots \ldots \ldots \ldots \ldots \ldots \ldots \ldots$

Legend $\ldots \ldots \ldots \ldots \ldots \ldots \ldots \ldots \ldots \ldots \ldots \ldots \ldots \ldots \ldots \ldots \ldots \ldots \ldots \ldots \ldots \ldots \ldots \ldots \ldots$

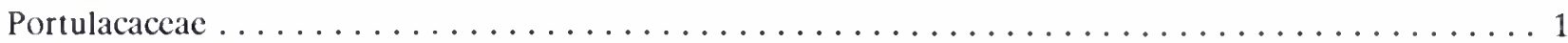

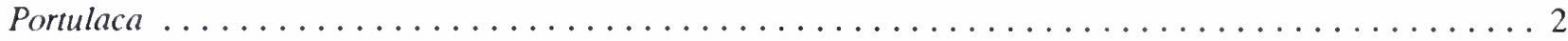

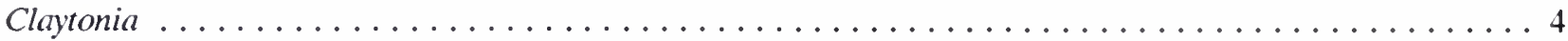

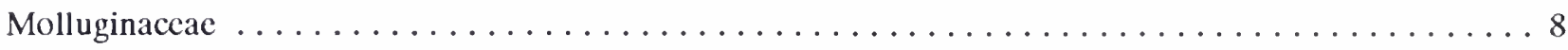

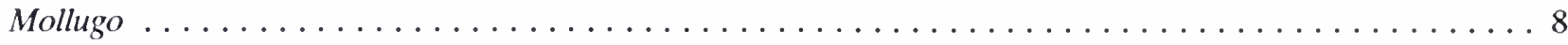

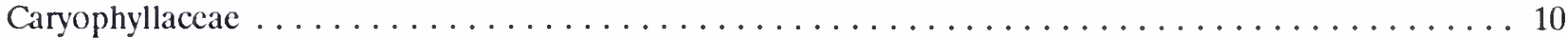

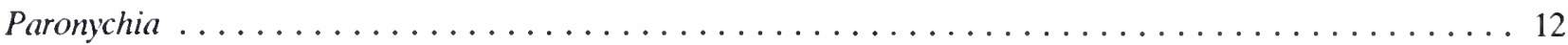

Herniaria . . . . . . . . . . . . . . . . . . . . . . . . . . . 15

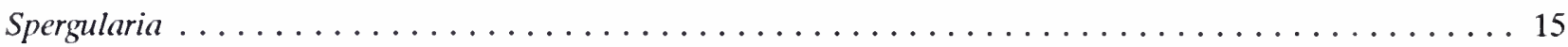

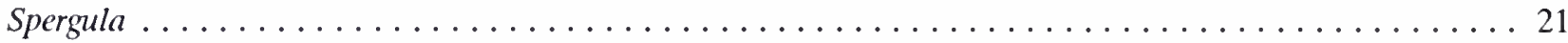

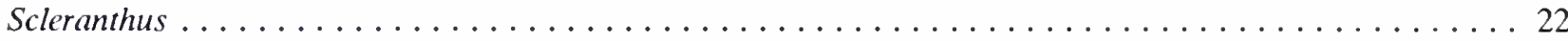

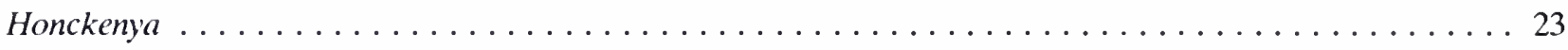

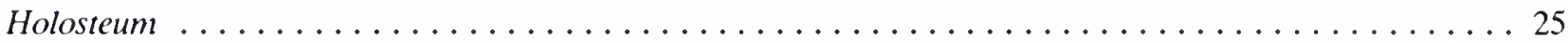

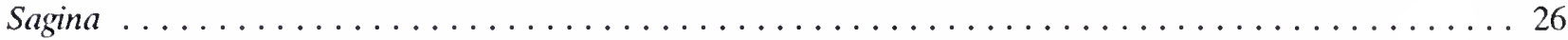

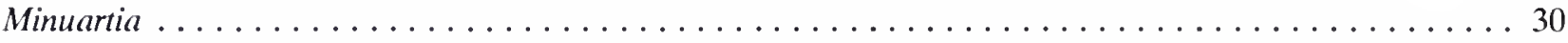

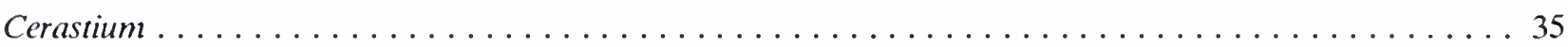

Moehringia . ...................................... 43

Arenaria . . . .................................... 45

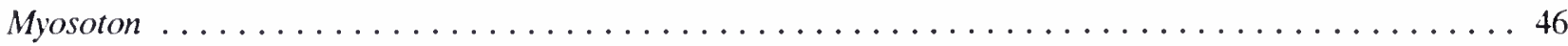

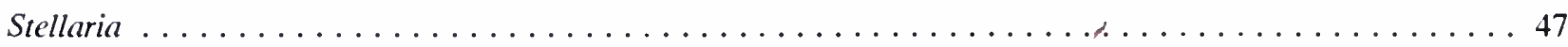

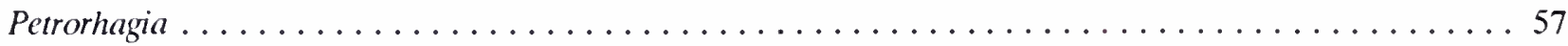

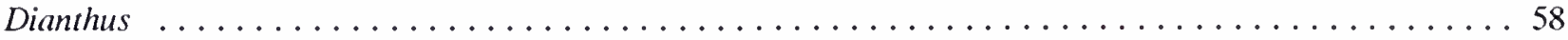

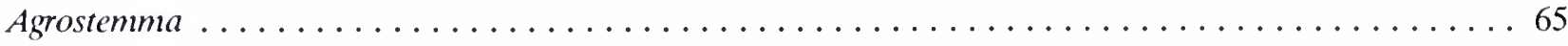

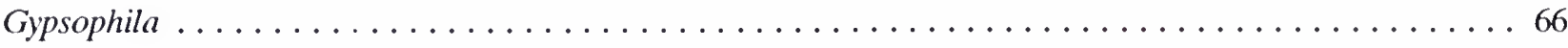

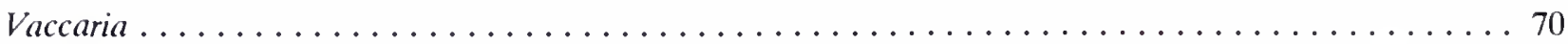

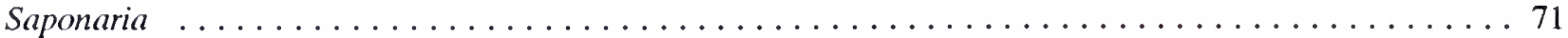

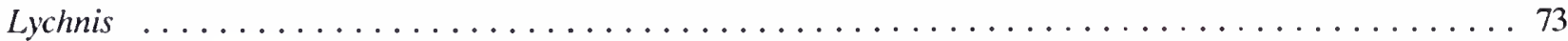

Silene .......................................... 77

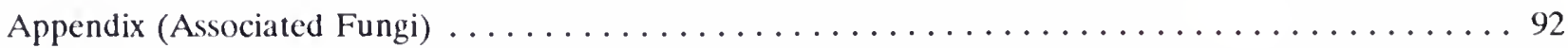

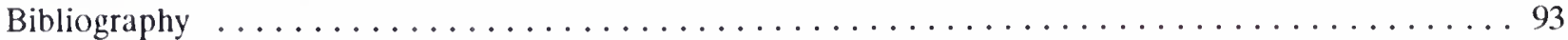

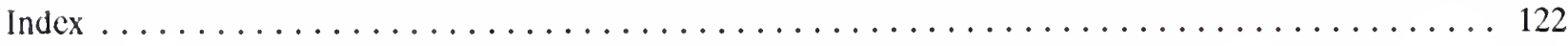




\section{ACKNOWLEDGMENTS}

The illustrations in this treatment are by Bobbi Angell, whose botanical knowledge and extensive use of fresh plant materials for the illustrations have added immensely to the value of the work. My special thanks go to Richard K. Rabeler who generously shared his bibliographic and botanical knowledge of the Caryophyllaceae, contributing significantly to the quality of this volume. He also added distribution records from specimens observed at the Hoysradt Herharium, Hartwick College, NY ( $\mathrm{HHH})$, and the University of Michigan $(\mathrm{MlCH})$. I would like to express my appreciation to the staffs and curators of the following institutions for helpful cooperation and hospitality when I visited their collections: The New York Botanical Garden (NY), Cornell University (CU, BH), Syracuse University (SYRF), Harvard University (GH, NEBC), and The Buffalo Museum of Science (BUF). Thanks to the staff of the Brooklyn Botanic Garden (BKL) for a loan of their Caryophyllaceae from New York State. Data from the above collections were entered into computers for later use in the GIS system and to update the master map-files of plant distribution at the New York State Museum (NYS). The classification system employed here is that of Arthur Cronquist (1981).

\section{IMPORTANT NOTE}

All economic uses, folklore, medical and pharmaceutical notes, uses as foodstuffs, etc., are compiled from the literature and do not represent an endorsement by the authors or the New York State Museum. Some of the uses may, indeed, be dangerous if incorrectly employed. Some are not effective and are presented for historical interest only. 


\section{FOR ALL MAPS IN THE PUBLICATION}

THE FOLI.OWING SYMBOLS APPLY

Solid dot---specimen seen by author: data on file at the State Herbarium (NYS)

Circle---field or herbarium observation not seen by author, with location data and observer's name or literature citation on file (NYS) 


\section{Portulacaceae (Purslane Family)}

The Portulacaceac: a family of almost cosmopolitan distribution with about 20 genera and over 450 species. By far, the largest numbers of species belong to four genera: Talinum (ca. 50), well represented in western North America, with a few species in the midwestern and southeastern states; Anacampseros of Africa, with about 60 species; Portulaca, with over 100 species, some of which have horticultural significance; and Calandrinia, the largest genus, with 150 species or more. Diversity within the family is greatest in western North America and southern South America. In New York State, two native Claytonia species occur, and two portulacas are found as naturalized garden escapes.

\section{FAMILY DESCRIPTION}

Annual or perennial herbs or suffrutescent shrubs; stems sometimes succulent. Perennial species proliferate by stolons, rhizomes, bulblets or corms. Leaves are opposite, alternate, crowded at the bases of flowers (or clusters) or in basal rosettes, almost always simple and entire and often somewhat fleshy. Stipules are dry or setiform (absent in Claytonia). Flowers are bisexual (rarely unisexual), borne in racemes, cymes, panicles or loose heads, usually regular, the perianth of two series; tepals are free or slightly connate at base, the inner series often called petals, though they are interpreted morphologically as tepals subtended by involucral bracts. The petals (inner tepals) are 2-6 (-20), deciduous or persistent, white or variously colored; sepals (outer tepals or bracteoles) are $2(-9)$, green or suffused with color. The stamens are borne opposite the petals, equal in number (or 2-4 times the number, by splitting). The anthers dehisce by longitudinal slits; filaments are free or basally adnate to a short tube, often associated with nectaries or a nectary ring. The gynoecium is free or slightly adnate to the perianth, a compound ovary with 2-3 (-9) carpels and free styles (or a single lobed style). The developing ovary becomes unilocular with free central placentation, ripening into a circumscissile capsule or loculicidal capsule with lateral (or apical) valves, or it is rarely an indehiscent nut. Ovules are 2 to many (rarely 1), bitegmic and variously disposed but often basal; seeds are frequently lenticular, shiny or tubercled, bearing a large embryo peripherally, curved around a copious, starchy perisperm.

\section{KEY TO GENERA}

1. Capsule dehiscing by a lid; flowers closely subtended by leaves, whether borne singly or in small clusters; annuals with weak root systems $\ldots \ldots \ldots \ldots \ldots \ldots \ldots \ldots \ldots \ldots \ldots \ldots \ldots \ldots \ldots$

1. Capsule dehiscing by vertical valves; flowers borne in slender, naked racemes or cymes (occasionally a single flower on a peduncle); perennials with corms or runners $\ldots \ldots \ldots \ldots \ldots \ldots \ldots \ldots \ldots$ (2)

2. Cauline leaves almost always borne in a single pair; stems arising from a deep corm, 1-many, ascending or prostrate at ground level, but not laterally branched upward or spreading by stolons . 2. Claytonia

2. Cauline leaves commonly more than 2; stems branching upward, proliferating by slender stolons at their

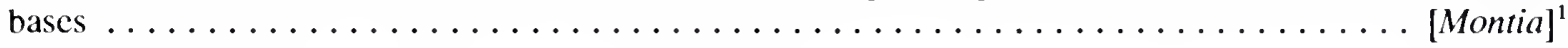

\footnotetext{
${ }^{1}$ Montia chamissoi (Esch. ex Ledeb. in Spreng.) Dur. \& Jacks. is reported from two sites in Pennsylvania, where it occurs on the banks of the Delaware River, only yards from the New York State border. Suitable habitats have not been found in searches on the New York side, but the plants may eventually be discovered there. Montia chamissoi is primarily a western species, distributed from Alaska to California, Iowa and Minnesota. Pennsylvania populations are likely relics of eastward postglacial migrations, though their native status has been questioned. Two other species of Montia have been reported as introduced in the eastern United States; however, the pattern of distribution of $M$. chamissoi is reminiscent of those of other western taxa, like Adoxa moschatellina L. and Juncus ensifolius Wikst., disjunct from northern-central states to southeastern upstate New York.
} 


\section{PORTULACA}

Common Names: Purslane, Portulaca

Authority: Linnacus, Species Pl. I, p. 445, 1753

A genus of 100-130 species worldwide, distributed mostly in the drier regions of the subtropics and tropics as well as in Mediterranean and Austral climates. Several species are cultivated and popular in rock gardens.

Description: Plants with bisexual flowers; stigmas at the style branches, often deeply cleft; ovary 1, often partially inferior, with many campylotropous ovules borne on a basal placenta; fruit a circumscissile capsule; seeds numerous with curved embryos and a starchy perisperm; stamens 5-many; filaments slender; anthers often globose; perianth of 2 whorls; petals (tepals) free or coherent into a short tube, 5-many; sepals (bracteoles) usually 2, free, accrescent, green or suffused with color; pedicels sometimes present; peduncle present or flowers sessile; bracts often present in the inflorescence; inflorescences of various types of clusters or flowers solitary; leaves opposite, alternated or whorled, particularly subtending flowers or flower clusters, often semisucculent, broad to linear and terete; petioles well defined to lacking; stipules scarious, often minute; stems usually glabrous, dry to succulent, creeping to erect; root systems often shallow.

\section{KEY TO SPECIES}

1. Leaves mostly linear, quite succulent, broadly oval to terete in cross-section; stamens $20-40$ or more; flowers showy, ca. $2-4 \mathrm{~cm}$ broad, red, pink, yellow, orange, purple or white . . . . . . . . 1. P. grandiflora

1. Leaves obovate to spatulate, succulent but flattened; stamens 7-12; flowers ca. $1 \mathrm{~cm}$ broad, yellow .....

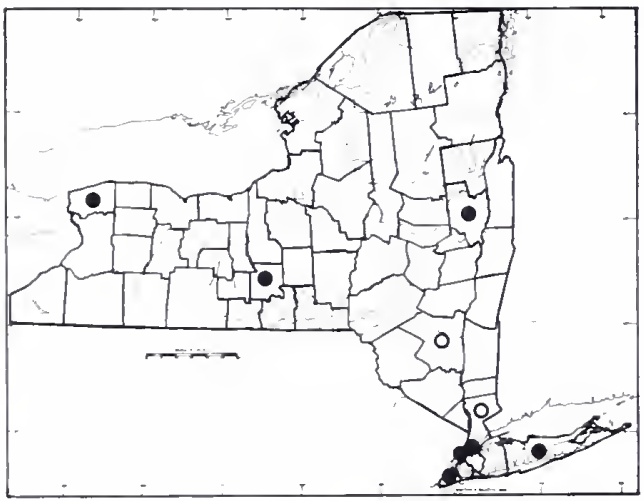

1. Portulaca grandiflora Ilook.

Common Names: Moss-rose, Rose-moss, Common or Garden Purslane, Sun- plant, Eleven-o'clock, Portulaca

Type Description: Hooker, Bot. Mag., vol. 56, pl. 2885,1829

Origin: A native of South America

Ilabitats: A garden escape on dry, gravelly or rocky soils, lake shore sands, cultivated ground and other disturbed areas

Ilabit: Annual, creeping and ascending herbs

Flowering: (May) June-September

Fruiting: June-November

General Distribution: Commonly escaping from cultivation south of our area, but rare from New Jersey northward

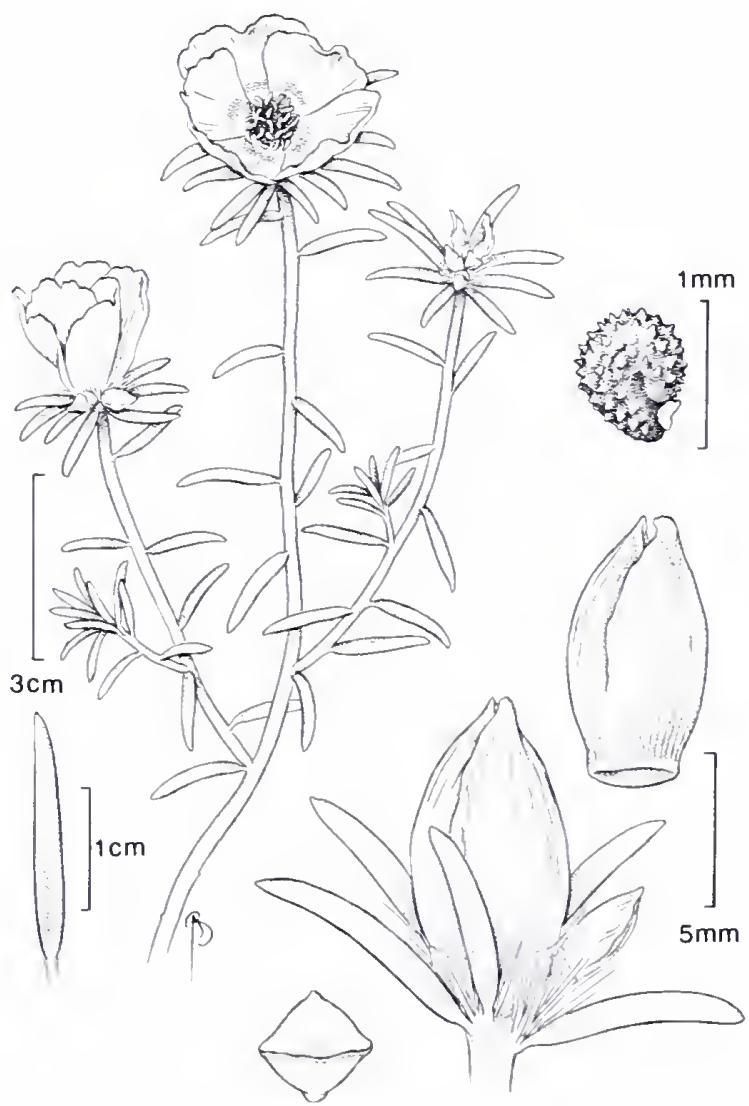


Description: Plants with bisexual flowers; stigmas 5-10, often 8, diverging lobes, spatulate or lacerate, 1.5-2.2 $\mathrm{mm}$ long, ca. $0.5 \mathrm{~mm}$ broad; style 1, tubular, $0.6-2.3 \mathrm{~cm}$ long, reddish-brown or the same color as the perianth; ovary ovate, ca. $2 \mathrm{~mm}$ long, often surrounded by a shallow, perigynous perianth cup; fruit a circumscissile capsule with a corky suture at its circumference, spheroid, 4-7 $\mathrm{mm}$ long and broad, the common style base persistent as a nipple at the apex, capsule surface glossy, greenish-tan to burnished or golden-brown; seeds many, ca. $0.7 \mathrm{~mm}$ long, $0.5 \mathrm{~mm}$ broad, comma shaped, the surfaces prominently tuberculate, dark brown with an opalescent sheen; stamens numerous, $5-7$ (9) $\mathrm{mm}$ long; anthers minute, golden or colored like the flower; filaments thread-like, arched, adnate to the petal bases dark rose to pale; perianth of two whorls (sometimes interpreted as tepals and bracteoles); petals 4-6 (multiple in most cultivars), red, rose-purple, white or yellow, often striped, $1.3-3.5(4) \mathrm{cm}$ long, $0.4-2.8 \mathrm{~cm}$ broad at tips, obovate to obspatulate or truncate-emarginate, the tips lobed, wavy or lacerate, bases cuneate, free or fused into a short cup, subtended by a dense tuft of woolly to villous hairs; sepals $4-12$, similar to the leaves but less succulent and flatter with distinct lower midribs, greenish with hyaline margins, linear with blunt tips, $4-13 \mathrm{~mm}$ long, $0.7-1.2 \mathrm{~mm}$ broad, subtended by tufted, villous hairs; flowers sessile, borne singly, usually on upwardly arching lateral branches; leaves alternate, succulent, linear-lanceolate, broadly oval to subterete in cross-section, with blunt to acute tips, 5-25 (32) $\mathrm{mm}$ long, 1-4 (6) $\mathrm{mm}$ broad, rich green with paler bases, the surfaces translucent-muricate; petioles ca. $1 \mathrm{~mm}$ long with minute, hyaline wings; stems semisucculent to coarsely fibrous near the base, creeping or suberect, with upwardly arching lateral branches $1025(31) \mathrm{cm}$ tall; root system a shallow, annual taproot with coarsely fibrous lateral roots $(2 \mathrm{n}=10,18$; artificial polyploids are known in cultivation).

Infraspecific Variation: The moss-rose is extremely variable in flower size and color, sometimes even bearing striped or multicolored flowers. Dwarf mutants are known, and these variants may also have very broad leaves. Importance: The moss-rose is widely cultivated in sunny, tropical and temperate climates; it thrives in areas with Mediterrancan dry summers and moist winters. Used as a rock garden or beachfront plant, it can provide a variety of brilliant colors to otherwise sandy or rocky, barren spots in full sun.

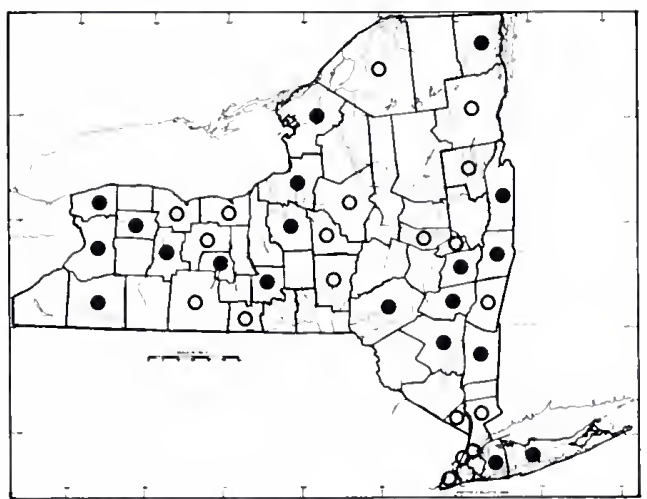

\section{Portulaca oleracea $\mathbf{L}$.}

Common Names: Garden or Kitchen Purslane

Type Description: Linnacus, Species Pl. 1, p. 445, 1753

Origin: Eurasian, its native range unknown

IIabitats: A common weed in gardens, less commonly naturalized in fields, land fills and other disturbed areas, and occasionally found in calcareous, open habitats with native flora

IIabit: Annual, sprawling, prostrate to weakly ascending, succulent herbs forming mats

Flowering: July-October

Fruiting: Aug.-November
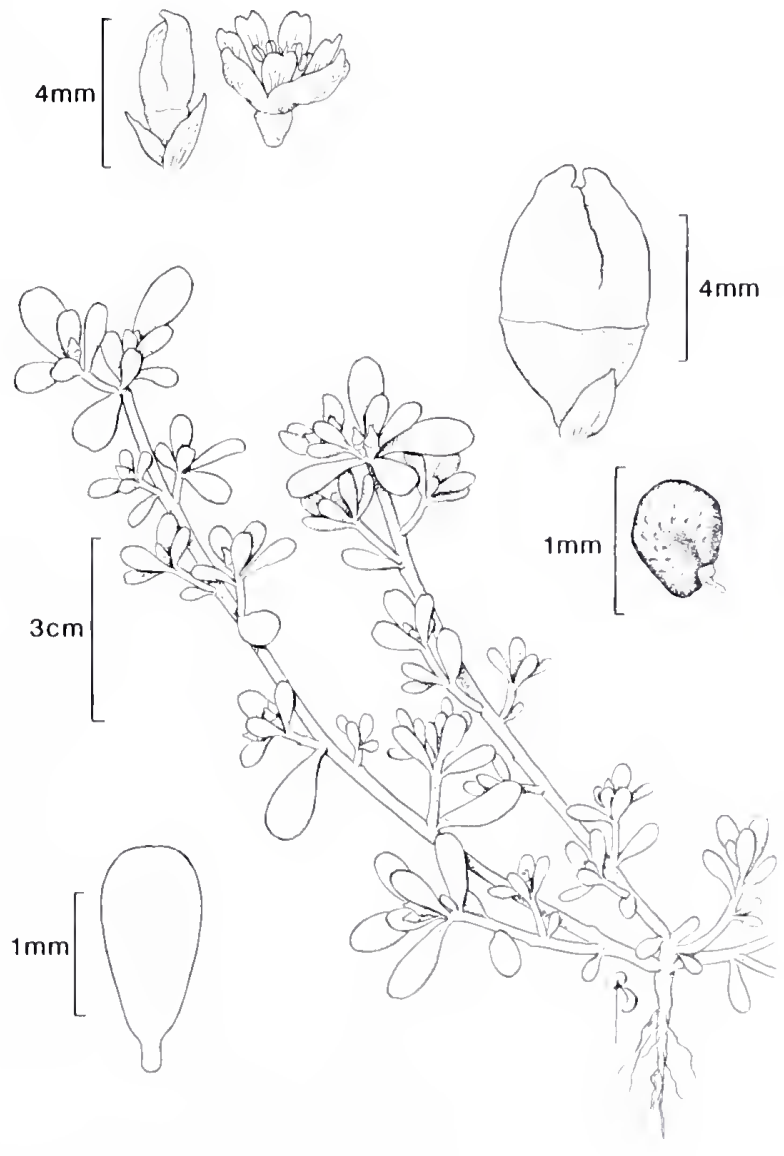
General Distribution: Naturalized and weedy across the United States, southern Canada and

elsewhere around the world, including Eurasia, where it is also native

Description: Plants with bisexual flowers, ephemeral, usually opening only on sunny mornings; stigmas as many as the style branches; style 1, deeply (3) 4-6 cleft; ovary fusiform, unilocular, minute; fruit a smooth, circumscissile capsule, $5-7 \mathrm{~mm}$ long, $3-4 \mathrm{~mm}$ broad, ovoid, acute at the tip, the valve prominent, dehiscing along the circumference just below the middle of the capsule, the base remaining, cup-like, with a prominent tuft of funiculae at its center after seed-scatter; seeds $8-12$ or more, ca. $0.7 \mathrm{~mm}$ long, 0.5 broad, dark brown, shiny with muricate to bluntly-tubercled surfaces and a small, pale caruncle; stamens 7-12; anthers golden, minute; filaments linear; perianth of two whorls, appearing epigynous from capsule suture in fruit; petals 4-5, yellowish, their limbs ovate, sometimes lobed or fimbriate at tips, $2-5 \mathrm{~mm}$ long and broad (or up to $1 \mathrm{~cm}$ in some cultivars); sepals 2, ca. $3 \mathrm{~cm}$ long and broad, greenish, persistent, enclosing the capsule lid in fruit and forming a keel-like projection beyond its tip; peduncles very short, virtually absent; inflorescences small clusters of subsessile flowers or flowers solitary; bracts subtending the flowers and clusters variable in size and shape ranging from leaf-like cordate-cuspidate bracts ca. $1 \mathrm{~mm}$ in diameter to minute, linear structures, with tufts of a few thick hairs in their axils; leaves semisucculent, alternate, subopposite or whorled at the branch tips below the flower clusters, spatulate to truncate or emarginate-tipped, cuneate toward the base, ranging from minute and bract-like up to $2-3 \mathrm{~cm}$ long, $1.5 \mathrm{~cm}$ broad, sometimes with tufts of hairs in their axils, (leaves) sessile or petioles poorly defined, up to $6 \mathrm{~mm}$ long; stipules lanceolate, 1-2 $\mathrm{mm}$ long; stems somewhat succulent, often much-branched, with many short, lateral shoots, prostrate to weakly ascending at the tips, the nodes sometimes enlarged, red, internodes short near the branch tips, up to $8 \mathrm{~cm}$ long near the plant base, greenish to red, stems spreading and mat-forming, up to $50 \mathrm{~cm}$ long; root system fibrous, shallow, adventitious at the lower nodes with damage. $(2 \mathrm{n}=28,54)$

Infraspecific Variation: The cultivar, sometimes called ssp. sativa (Haw.) Celak., is robust, more succulent than its wild-growing counterpart, and the branches are ascending to erect, sometimes reaching $50 \mathrm{~cm}$ in height. Such plants known as garden escapes in Greene County, New York. Another cultivar (var. giganthes Bailey) has double flowers up to $2.5 \mathrm{~cm}$ in diameter. Flower colors other than yellow are known in cultivation, but, so far, these have not been reported as escapes within our range.

Importance: The 'Giganthes' cultivar of this species, with flowers up to an inch broad, is grown as an ornamental, while the more erect, succulent $P$. oleracea cv. Sativa, is well known as a cultivated salad and pot herb, variously called kitchen purslane (purselane), garden purslane or pusley. It is eaten raw, boiled or fried in grease, or pickled and stored for winter use. The weedy form of the plant is occasionally eaten as a salad herb, but rarely cultivated for that purpose. Purslane is known to be mildly diuretic, and the plants have been reported to concentrate dangerous levels of oxalate crystals. They are cited as a cause of oxalic acid poisoning when eaten in large quantities by sheep and other livestock. In folk medicine and kitchen lore, the plants are reputed to cure excessive thirst, dry throat and loose teeth. Purslane has been used in Europe and Asia in external medicinal applications, such as poultices for reduction of fever, soothing inflamed eyes, and as a packing for wounds. It contains significant amounts of Vitamin C, and there are reports of its use on 16th century sailing vessels to treat and prevent scurvy. Portulaca oleracea is also a carrier of the tomato spottedwilt virus.

\section{CLAYTONIA}

\section{Common Name: Spring Beauty}

Authority: Linnaeus, Species Pl. 1, p. 204, 1753

A genus of 15-20 species with its center of greatest diversity in western North America, but with species distributed from eastern North America to South America, Asia, Australia and New Zealand. Our two closelyrelated species are spring ephemerals of little horticultural value, but they are sometimes transplanted from the wild into gardens as a curiosity.

Description: Plants with bisexual flowers; stigmas 3, on the lobes of the style; style 1, 3-lobed at apex; ovary 1, superior, becoming unilocular, with 6 ovules borne on a central placenta; fruit a capsule, dehiscing by the inrolling of the margins of its 3 valves; seeds 1-6; embryo peripheral to a starchy perisperm (true endosperm lacking); stamens 5; filaments adhering to the petal claws; anthers elongate; perianth of two whorls; petals 5, free, clawed at base, oval to elliptic, spreading; sepals 2, accrescent; pedicels slender, bracteose, often lax 
or recurved in fruit; peduncles slender to somewhat fleshy; bracts scarious or herbaceous; leaves usually one to several at the plant base, cauline leaves commonly borne as a single, opposite pair, linear to oval, rhombic or oblanceolate; petioles indistinct to well-developed; stipules absent; stems slender, 1-many, arising from a corm buried an inch or more beneath the soil surface; root system delicate to fibrous and wiry.

\section{KEY TO SPECIES}

1. Cauline leaves linear to narrowly oblanceolate, more than seven times longer than broad; petioles absent or poorly defined; capsule ovate, usually bearing 3 or more seeds; the lowermost inflorescence bract often

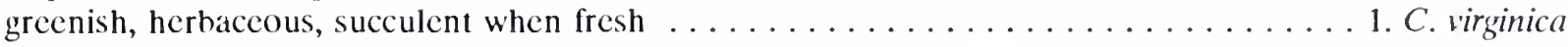

1. Cauline leaves ovate to rhombic or broadly oblanceolate, fewer than seven times longer than broad, their petioles \pm distinct; capsule cylindric-ovate, usually bearing a single seed; lowest inflorescence bract scarious

2. C. caroliniana

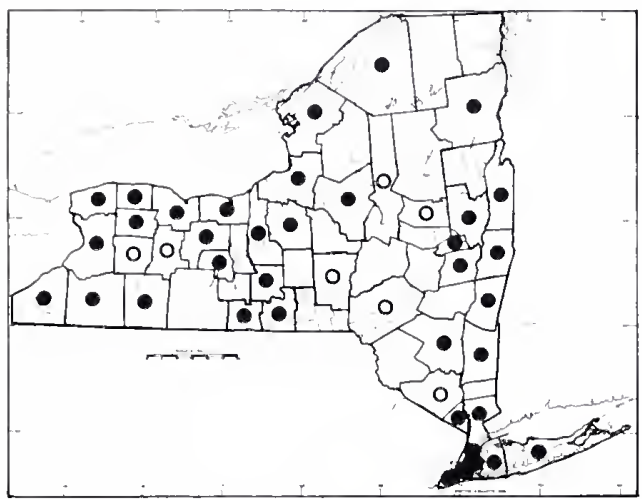

1. Claytonia virginica $\mathrm{L}$.

Common Names: Spring Beauty, Mayflower, Grassflower, Rose Elf, Good-morning-spring, Wild Potato, Fairy-spuds

Type Description: Linnacus, Species Pl. I, p. 204. 1753

Synonyms: Claytonia media (DC.) Link, not Small, C. multicaulis var. robusta Somes, C. robusta Rydb., C. simsii Sweet, C. virginica var. acutiflora DC., C. virginica var. simsii (Sweet) R. Davis

Origin: Native to eastern North America

Ilabitats: Moist woodlands thickets and stream banks often in litter, relatively sun-tolerant, persisting in fields after clearing

IIabit: Perennial, ephemeral herbs with slender, decumbent to erect, semi-succulent stems arising from a corm

Flowering: (March further south) April-May

Fruiting: May-June (carly July)

General Distribution: Southwestern Quebec and New England west to Minnesota and south to eastern Texas and Georgia

Description: Plants with bisexual flowers; stigmas 3, receptive at the tips and along the adaxial surfaces of short style branches; style 1, very slender, $4-7$ (9) mm long, with 3 recurved, stigma-bearing branches 0.8-1.4 $\mathrm{mm}$ long at the tip; ovary ovoid, ca. $1.5 \mathrm{~mm}$ long and broad; fruit a tan capsule, ovoid to broadly cylindric with 
an obtuse to acuminate tip, $3.5-5.5 \mathrm{~mm}$ long, $3.4-4.6 \mathrm{~mm}$ broad, enclosed in the persistent calyx, dehiscing by 3 vertical sutures and valves; seeds 3 (4-6), ovoid, ca. $2.5 \mathrm{~mm}$ long, $2 \mathrm{~mm}$ broad, slightly ribbed, the surface shiny, deep red-brown; stamens 5, opposite the petals; anthers $1.8-2.3 \mathrm{~mm}$ long, ca. $0.7 \mathrm{~mm}$ wide, golden to deep pink; filaments linear, pale, $2-4 \mathrm{~mm}$ long, adnate to petal claws at base; perianth of two series; petals (tepals) 5, slightly clawed at base, the linear-oblong to broadly ovate or obovate limbs spreading above the calyx, (3) 5-15 (23) mm long, 2-9 (11) $\mathrm{mm}$ broad, white or pink tinged to deep rose, the margins entire or erose at petal tips; sepals 2, accrescent, 3-15 (25) $\mathrm{mm}$ long, 3-19 mm broad, oval, cucullate, tips rounded to broadly acute (often appearing acute on pressing), glabrous, greenish, somewhat fleshy; pedicels glabrous, very slender, (0.2) 1-2 (3.2) cm long, elongating during flowering, drooping or reflexing in fruit; peduncle erect or ascending, glabrous, 2-35 (40) $\mathrm{mm}$ long, bearing a single raceme, or inflorescence branched into $2-4$ raceme axes, up to $10 \mathrm{~cm}$ long with (2) 3-12 (20) flowers per plant; bracts present at the bases of some of the lower pedicels, the lowermost lance-ovate, $2-5(10) \mathrm{mm}$ long, $0.5-3.5 \mathrm{~mm}$ broad, often remaining green and herbaceous into the fruiting period; cauline leaves borne in a single, opposite pair (rarely terminal to a short, lateral shoot) strap-like, linear to lanceolate or oblanceolate, generally 7 times longer than broad or more, (2) 5-12 (16) $\mathrm{cm}$ long, (0.1) 0.2-1.3 (2.5) cm broad, glabrous with a rimmed, entire margin (rarely a small dentation), tips acute to quite blunt; basal leaves 0-2 (4), similar to cauline leaves when present; petioles obscure, poorly differentiated, grading imperceptibly into the leaf blade; stems (1) 2-25 (40), unbranched, slender and pale beneath the soil, erect-ascending from a corm to ground level where they may become decumbent, ascending or remain erect, greenish and somewhat succulent above-ground, $2-18 \mathrm{~cm}$ long, measured from the corm to the base of the peduncle at the node of the cauline leaves; corm 1.4 (10) cm long and broad, spheroid to oval or pear-shaped, dark and scaly, richly white-starchy within; roots tough and knotted, branching profusely from the surface of the corm (chromosome numbers range from $2 n=12$ to over 190; aneuploid series are well documented within populations, and somatic numbers may vary between different tissues of the same plant). Infraspecific Variation: A number of local and regional races are known, some of which correlate with cytological differences. The sizes of plants and their parts are quite variable, the following examples being noteworthy; a large form with leaves up to $2.5 \mathrm{~cm}$ broad and $15+\mathrm{cm}$ long has been called forma robusta (Somes) Palmer. In some plants of this type from Central New York State, the inflorescence attaches below the cauline leaf-pair, which is terminal to a short-shoot up to a centimeter long. Delicate plants with grass-like, linear leaves are also frequent from New York to the Midwest. Plants with reduced perianths and petals that are sometimes shorter than the stamens, have been called forma micropetala Fern. Flower color varies within and between populations, ranging from greenish-white to pure white, the petals often reddish tinged or veined, with extreme variants ranging into deep, rose-purple (rarely orange-yellow) hues.

Importance: These plants are sometimes grown from seed or brought from the wild into gardens and yards to provide ephemeral spring wildflower beds or borders. The corms were eaten by Native Americans and European settlers in eastern North America, used as a starchy food supplement. They are still eaten by wild plant enthusiasts, and are said to have a flavor similar to chestnuts or potatoes when boiled in salt water or added to stews. They are difficult to dig, however, and large populations are necessary to provide any significant nutrition. This species has proved to be of special scientific interest cytologically, due to chromosome number instability, including age-induced abnormalities (Lewis, 1970). 


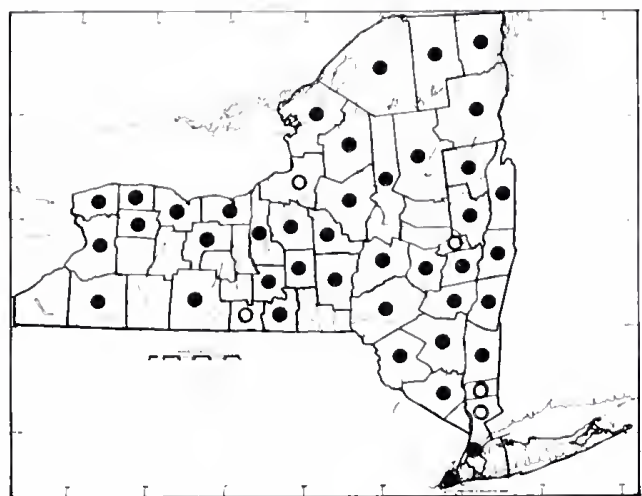

2. Claytonia caroliniana Michx.

Common Names: Spring Beauty, Carolina or White Spring Beauty, Carolina Mayflower, Wild Potato, Fairy-spuds, Tangle-gut

Type Description: Michaux, Fl. Bor. Am. vol. 1, p. 160,1803

Synonyms: $C$. latifolia Sheldon, not Suksdorf

Origin: Native to eastern North America

IJabitats: Woodland slopes clearings, mixed conifer hardwood forests, thickets and bottomlands, often in rich soils and partial shade

Ilabit: Perennial, ephemeral herbs with slender, decumbent to erect, semi-succulent stems arising from a corm

Flowering: Mid April-May (March further south)

Fruiting: May-June (early July)

General Iistrilbution: Newfoundland to Saskatchewan south to Illinois, and, in the east, down the Appalachians to North Carolina and Tennessee

Description: Plants with bisexual flowers; stigmas 3, receptive at the tips and along the adaxial surfaces of short style branches; style 1, very slender, 1.2-3.6 mm long, with 3 recurving, stigma-bearing branches 0.7-1.2 $\mathrm{mm}$ long at the tip; ovary ovoid, ca. $1.5 \mathrm{~mm}$ long; fruit a tan, ovoid-cylindric capsule with an acute to acuminate tip, $4.0-4.5 \mathrm{~mm}$ long, ca. $2.5 \mathrm{~mm}$ broad, enclosed in a persistent calyx, dehiscing by 3 vertical sutures, and narrow inrolling valves; seeds (in ours) 1-2, ovoid-lenticular, 1.8-2.2 mm long and broad, the surface very lustrous, deep reddish-brown to ebony; stamens 5, opposite the petals; anthers $1.3-1.9 \mathrm{~mm}$ long, ca. $0.4 \mathrm{~mm}$ wide, pink to golden; filaments linear, pale, mm long, adnate to petal claws at base; perianth of two series; petals (tepals) 5 , slightly clawed at base, the linear-oblong to broadly ovate or obovate limbs spreading above the calyx, (3) 5-12 mm long, 2-7 (9) mm broad, white or pink tinged, the margins entire or erose at petal tips; sepals 2, accrescent, $3-7$ (11) $\mathrm{mm}$ long, $2-6 \mathrm{~mm}$ broad, oval, the tips obtuse to acute, glabrous, greenish, somewhat fleshy; pedicels glabrous, very slender, (0.2) $1-2.3 \mathrm{~cm}$ long, elongating during flowering, drooping or reflexing in fruit; peduncle erect or ascending, glabrous, $3-35 \mathrm{~mm}$ long, bearing a single raceme, or inflorescence branched into 2-4 raceme axes, up to $8 \mathrm{~cm}$ long with (1) 3-13 (28) flowers per plant; bracts present at the bases of some pedicels, the upper ones linear, minute, scarious, the lowermost lance-ovate, 1-6 $\mathrm{mm}$ long, 0.5-3.5 mm broad, often scarious or hyaline, sometimes totally withered by the time of fruiting; cauline leaves borne in a single, opposite pair, ovate to ovate-lancelate, rhombic, broadly oblanceolate or spatulate, generally 3-5 times longer than broad, the blade $1.2-6.2 \mathrm{~cm}$ long (0.3) $0.5-2.5 \mathrm{~cm}$ broad, glabrous with a rimmed, entire margin (rarely one or more very shallow dentations), pale green, often glossy, the tip usually obtuse; basal leaves $0-5(9)$, similar to cauline leaves but often shorter with longer petioles; petioles usually well differentiated, (0.1) 0.5-2.5 (3) cm long on cauline leaves, up to $7 \mathrm{~cm}$ on basal lcaves; stems (1) 2-20 (30), unbranched, slender and pale beneath the soil, erect-ascending from a corm to ground level where 
they may become decumbent, ascending or remain erect, greenish and somewhat succulent above-ground, 3-14 $\mathrm{cm}$ long (measured from the corm to the base of the peduncle at the node of the cauline leaves); corm 1.0-2.8 $(3.5) \mathrm{cm}$ long and broad, spheroid to oval or pear-shaped, dark and scaly, richly white-starchy within; roots tough, twisted and knotted, branching profusely from the corm surface $(2 \mathrm{n}=16,24)$.

Infraspecific Variation: Plants native to northeastern North America usually bear a single seed per capsule, whereas those of other geographic regions are said in the literature to have three or more. Cauline leaves are usually petioled, but occasionally the petiole is obscure. Although sepals of this species are reported to be acute in the manuals, this is rarely the case, although the margins may be obscurely attenuate before terminating in an obtuse to blunt tip; the acute appearance is likely to be an artifact of pressing and drying specimens.

Importance: These plants may be grown from seed, and the corms are propagated easily, so they are sometimes planted in gardens for a brief show of spring color. The corms are also edible, known as a food source since pre-Columbian times. They may be boiled or added to other dishes as a supplementary starch source; they are said to have a taste similar to chestnut or potato, but their small size (mostly under 1 inch in diameter) and brief blooming period make them of minor interest as an economic food source.

\section{Molluginaceae (Carpetweed Family)}

The Molluginaceae: a family of 13 genera and 70-100 species, centered in Africa, but found in both the New World and the Asiatic tropics and subtropics. Members of the family have formerly been treated under both Aizoaceae and Caryophyllaceae.

\section{FAMILY DESCRIPTION}

Annuals or perennials with herbaceous (to woody) stems, sometimes semisucculent. The leaves are whorled (in ours), opposite, basal or alternate, simple, entire; stipules may be present or absent. The flowers are usually perfect, hypogynous, often inconspicuous, borne in panicles or cymes, terminally or in verticils at the nodes. The ovary is of 2-5 (or more) fused carpels, often incompletely multilocular toward the base, bearing numerous ovules. Stamens are 3-10, free, sometimes with a nectary ring. Sepals (4) 5, often persistent in fruit; petaloid staminodes 0-20. Petals are lacking. The fruit is a valvate capsule (loculicidal in ours) or indehiscent. The curved embryo is borne within starchy perisperm.

\section{MOLLUGO}

Common Names: Carpetweed, Indian Chickweed

Authority: Linnaeus, Species Pl. I, p. 89, 1753

A genus of $12-15$ species of the tropics and subtropics. Our common carpetweed, Mollugo verticillata L. has spread widely from its original natural range further south in the Americas, and another species, M. cerviana (L.) Sér. is a waif and rare introduction in the southern part of New York State. This species is widespread in western states, where some have suggested that it is native.

Description: Plants with bisexual flowers; stigmas 3-5; styles 3-5; ovary 1, superior, $3-5$ ioculed; ovules numerous; fruit a 3-5 valved, thin-walled, loculicidal capsule; seeds many, lacking an aril or strophiole, commashaped, often ribbed, with a curved embryo surrounded by starchy perisperm; stamens 3-10; filaments slender; anthers small, ovoid; perianth of one or two whorls; petals and staminodes absent; sepals 5, free, greenish to white, persistent in fruit; pedicels slender; inflorescences cymose, or flowers verticillate at the nodes; bracts leaf-like or absent; leaves whorled at the nodes; petioles obscure; stipules absent; stems slender, forking, creeping to erect-spreading; root system a taproot. 


\section{KEY TO SPECIES}

1. Plants with spatulate to narrowly oblanceolate cauline leaves; flowers in verticils at the nodes and in small clusters at the leafy branch tips, lacking axillary peduncles . . . . . . . . . . . . . .

1. Plants with linear cauline leaves, often with a conspicuous basal rosette of broader leaves; flowers borne in terminal and peduncled, axillary racemes (also in verticils at the nodes) . . . . . [M. cerviana, a wail]

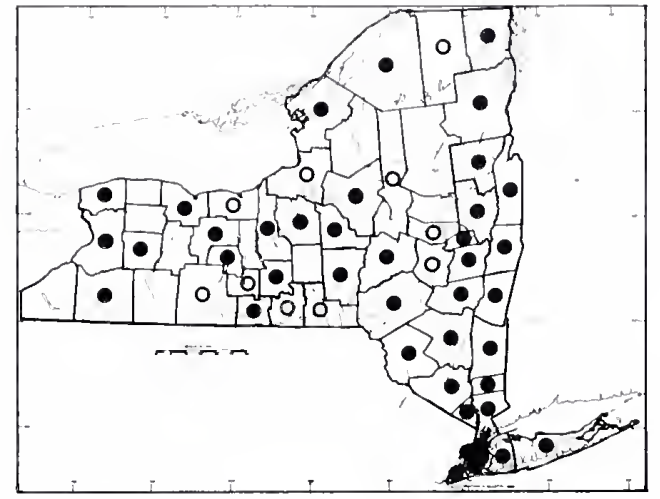

\section{Mollugo verticillata $\mathrm{L}$.}

Common Names: Carpetweed, Indian Chickweed, Devil's-grip

Type Description: Linnacus, Species Pl., p. 89, 1753

Synonym: $M$. berteriana Sér.

Origin: Native to tropical America

Ilabitats: A sun-loving weed of sandy roadways, fields, beaches, riverbanks and gardens

IIabit: Prostrate, mat-forming annuals with branch tips sometimes ascending

Flowering: Junc-November

Fruiting: June-December

General Distrilution: Wecdy throughout temperate North America from Quebec to British Columbia and southward to Central and South America, where it is partially native as well

Description: Plants with bisexual flowers; stigmas 3, pale papillate; styles 3, pale, closely associated but free, flexed outward at tips; ovary 1, superior, ovoid, 3-carpelled, ca. $0.5 \mathrm{~mm}$ long; fruit a loculicidal capsule, ovoid, $2.3-3.4 \mathrm{~cm}$ long, ca. $2 \mathrm{~mm}$ broad, glossy greenish to tan at maturity, somewhat transparent, appearing stretched by the dark, ribbed seeds when dry, the dorsal sutures evident as grooves before dehiscence; seeds many, comma-shaped, lustrous golden brown with prominent, dark brown ridges mostly on the dorsal surface, aril lacking; stamens 3 (4), hypogynous; anthers golden, ovate; filaments slender, pale, ca. $3 \mathrm{~mm}$ long, running directly up the grooves of the 3 sutures of the capsule as it develops; perianth of a single whorl; petals and petaloid staminodes absent; sepals 5, free to base, ovoid, cucullate, (1) 1.3-2.5 mm long, upper surface glossy, whitish, the lower surface greenish, often with 3 prominent, green veins and paler margins, glabrous, tips obtuse to broadly acute; peduncles slender, (1) 3-9 (16) mm long, glabrous, whorled at the nodes; inflorescence diffuse, consisting of terminal racemes, usually of 3-10 flowers, and axillary clusters of 2-5 (8) flowers borne with the leaf whorls at the nodes; bracts usually found in the terminal inflorescences only, greenish, linear, 0.3-1.6 mm long; leaves obovate to spatulate, oblanceolate (to nearly linear in some individuals), whorled, commonly $3-5$ per no'fe, 0.4-3.5 (4) $\mathrm{cm}$ long, up to $1 \mathrm{~cm}$ broad; glabrous, cntire, obtuse to acute (apiculate) 
at tips, tapering to a poorly differentiated petiole; stems very slender, glabrous, sometimes grooved, muchforked, decumbent to procumbent, up to $40 \mathrm{~cm}$ long; root system a slender, long, annual taproot $(2 \mathrm{n}=64)$. Infraspecific Variation: Leaf shape is quite variable, approaching the linear-leaved condition of $M$. cerviana in some plants. These have been called $M$. verticillata var. linearis Fenzl.

Importance: In sandy areas this can be a common weed of vegetable gardens and horticultural plantings. Carpetweed has been used as a pot herb, but its small size and stringy texture make it generally undesirable.

\section{Caryophyllaceae (Pink Family)}

The Caryophyllaceae: a family of some 80 genera and over 2,000 species worldwide, with about 60 species native or naturalized in New York State. The group has been subject to many interpretations historically, being variously subdivided into Illecebraceac, Alsinaceac, Corrigiolaceac, etc. Palynological evidence has also been offered in support of segregating the Paronychioideac as a separate family. Current morphological and chemical evidence, however, stands in favor of the recognition of a single, large family of anthocyaninproducing plants with free-central placentation and distinctive plastid ultrastructure. This concept may be revised with the advent of further studies Paronychia and related genera. Members of Caryophyllaceae are segregated from the Molluginaceac, thought to be more closely allied with the Aizoaceac. The center of diversity for the Caryophyllaceae is in the Mediterranean Region, but caryophylls have adapted to a broad variety of habitats around the world, often in sunny habitats, ranging from arctic-alpine to desert and Australmontane regions. Many species are weedy adventives within and outside their native lands, and a few are noxious crop-followers. Some caryophylls are cooked as pot-greens, especially in Eurasia, while others have been used in folk medicine. Several genera are widely cultivated for their floral beauty or usefulness as accents in flower arrangements. Some of the more popular of these in horticulture are: Dianthus (Caryophyllus), the carnations, sweet-williams and bachclor's buttons, Gypsophila, baby's-breath, Cerastium, snow-in-summer, and showy-flowered Lychnis species such as the Maltese-cross.

\section{FAMILY DESCRIPTION}

Annual, winter-annual, biennial or perennial herbs (sometimes woody; rarely shrubby) with unilacunar, often swollen, nodes. The simple, decussate, opposite or fascicled leaves (rarely alternate) are often narrow and entire, lacking petioles; leaf bases are connate, usually clasping the node and connected by a nodal line; stipules are absent in most genera, but these may be present as unfused appendages or even form a tubular sheath. Flowers are borne in a variety of mostly dichasial inflorescence configurations (occasionally singly), including panicles, spikes and cymes. The perianth is of two distinct series (or petals may be lacking/caducous), with parts in $4 \mathrm{~s}, 5 \mathrm{~s}$ or their multiples. The calyx may be chorisepalous or gamosepalous forming a tube that is accrescent and encloses the ripening fruit (inflated in some genera). In some genera there is an epicalyx of whorled bracts subtending the flower. The corolla is actinomorphic and choripetalous, although it may simulate a salverform condition when petal limbs diverge abruptly from claws tightly invested by the mouth of the calyx tube. Petals are clawed in some genera; the claw sometimes bears lateral auricles and/or petaloid to tubular appendages (coronal scales) at the apex of the claw, where it joins with the petal limb. Petal limbs may be entire, erose, dentate, emarginate, shallowly cleft, or deeply bifid, making the petal number appear double in some species. Stamens are (1-4) 5 or (8) 10, in one or two series (or lacking in female flowers of dioecious species), the filaments free or adnate to either petals, an androgynophore or a nectary disk. The dorsifixed anthers open by longitudinal slits. Flowers are usually bisexual, but certain species are characteristically dioecious. The gynoecium is of a single, superior ovary (perigynous in Scleranthus) of (1) 2-5 carpels, sometimes partially or wholly septate, but usually with free-central placentation. The ovary may be borne on a \pm conspicuous androgynophore or sessile. Ovules are borne variously (even singly), usually numerous, campylotropus with perisperm or nuclear endosperm. The styles are often free, numbering as many as the carpels or fewer, or there may be a basal fusion. The fruit is usually a capsule that dehisces by as many valves (or twice as many valves or teeth) as the styles; it is rarely a circumscissile capsule or a utricle. The fruit may be borne on a carpophore or not. Seeds are usually small, often ornamented and borne in large numbers. 
The dicotyledonous embryo is weakly to strongly curved (almost straight in Dianthus), sometimes forming a ring around the starchy perisperm.

Note: The generic key requires both flowers and mature fruit, but most caryophylls set fruit quickly and continue to bear both flowers and capsules through a significant part of the growing season.

\section{KEY TO GENERA}

1. Stipules present, conspicuous to minute, but distinct from the sheathing leaf bases (or petioles) ... (2)

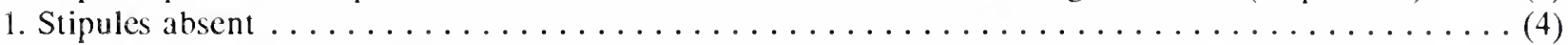

2. Fruit a dehiscent capsule with several to many seeds; styles $3-5 \ldots \ldots \ldots \ldots \ldots \ldots \ldots \ldots$. $\ldots \ldots \ldots$ (3)

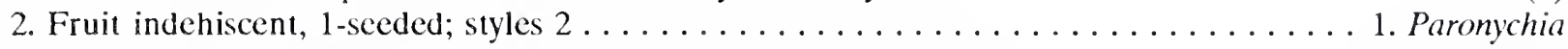

3. Styles 3 ; stipules united into a shallow, tubular sheath at the node . . . . . . . 2. Spergularia

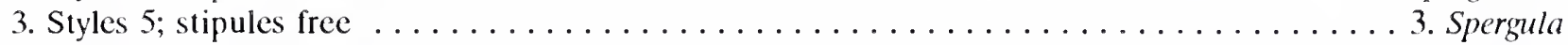

4. Fruit indehiscent, 1-seeded; calyx lobes borne on the rim of a small, leathery perigynous cup that fuses with the ovary and persists in fruit like an exocarp $\ldots \ldots \ldots \ldots \ldots \ldots \ldots \ldots$ Scleranthus

4. Fruit a dehiscent capsule with several to many seeds; calyx hypogenous, not becoming fused with the fruit

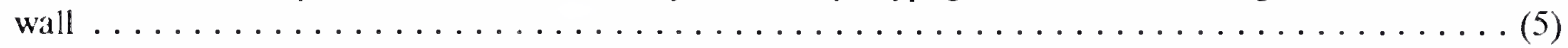

5. Stamens and petals attached to a conspicuous, lobed disk in the mouth of the flower; plants with broad, leathery, succulent leaves (sea beach habitats) $\ldots \ldots \ldots \ldots \ldots \ldots \ldots \ldots \ldots \ldots \ldots \ldots$ Honckena

5. Stamens and petals not attached to a conspicuous disk; plants without, broad, leathery, strongly succulent

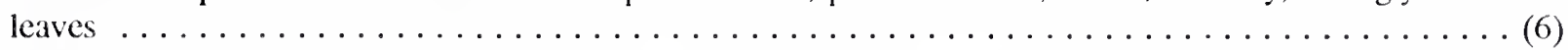

6. Sepals fused, at least near their bases, into a distinct tube or cup; petal tips expanded into limbs from narrower basal claws; capsule often borne on a stipe (carpophore) . . . . . . . . . . . (17)

6. Sepals free or minutely fused at base, but not forming a cup or tube; petals not noticeably clawed or constricted below; capsule never borne on a carpophore . . . . . . . . . . . . . . . (7)

7. Flowers (fruits) borne in a terminal umbel on a long, naked peduncle . . . . . . . . 6. Holosteum

7. Flowers (fruits) borne in cymes, panicles, corymbs, spikes or singly, but not in a long-peduncled umbel $(8)$

8. Petals absent

8. Petals present

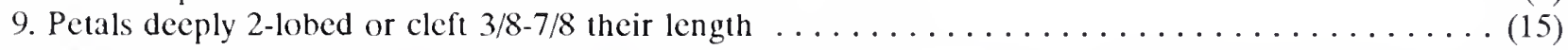

9. Petal tips rounded, emarginate or very shallowly cleft $\ldots \ldots \ldots \ldots \ldots \ldots \ldots \ldots \ldots \ldots \ldots \ldots$ (10)

10. Capsule valves shallowly to very deeply cleft into teeth; teeth more numerous than styles, often twice as many

10. Capsule valves uncleft upon dehiscence, thus, the lobes as many as the styles

11. Styles 5 (rarely 4); petals inconspicuous, barely longer than the sepals

11. Styles 3 (rarely 4); petals well-developed, significantly surpassing the sepals 7. Sagina

12. Capsule dehiscing by 10 short teeth surrounding a terminal pore

8. Minuartia

12. Capsule dehiscing by 6 valves or teeth

9. Cerastium

13. Sepals obtuse to acute, shorter than the petals; seeds often with a pale, spongy strophiole; percenial plans from from delicate rhizomes $\ldots \ldots \ldots \ldots \ldots \ldots \ldots \ldots \ldots \ldots \ldots \ldots \ldots \ldots \ldots \ldots \ldots \ldots$. Moehringia

13. Sepals acuminate, longer than the petals; seeds totally lacking spongy strophioles; annuals with slender

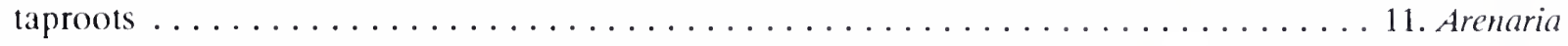

14. Capsule valves 5, blunt or round-tipped, not even shallowly cleft; (leaves needle-like) ... . 7. Sagina

14. Capsule valves 5 and shallowly bifid, or deeply cleft into 6-10 teeth; (leaves various) ....... (15)

15. Dehisced capsule with 5 valves, each shallowly bifid into 2 narrow teeth; styles $5 \ldots$. . . 12. Myosoton

15. Dehisced capsule with 6-10 subequal or irregular teeth (sutures between them may not always split); styles 3-5

16. Capsule dehiscent by an apical or subapical aperture, ringed with 10 (rarely 8 ) teeth, the fruit apex often asymmetrical; styles usually $5 \ldots \ldots \ldots \ldots \ldots \ldots \ldots \ldots \ldots \ldots \ldots \ldots \ldots \ldots \ldots$ Cerastum

16. Capsule dehiscent to about the middle or nearly to the base by 6 valve-like teeth (rarely $8-10$ ), the fruit apex not contorted; styles usually 3 (rarely $4-5$ )

13. Stellaria 
17. Calyx without basal bracts (an epicalyx); seeds plump

17. Calyx with an epicalyx of 1-3 pairs of bracts immediately subtending the tube; seeds laterally compressed

18. Calyx tube with 5 (to 15$)$ veins ( $1-3$ per lobe); commissures (veinless, scarious areas) present between

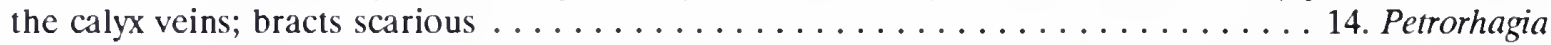

18. Calyx tube with 30 or more veins ( 5 or more per lobe), lacking commissures; bracts herbaceous ...

15. Dianthus

19. Calyx lobes $2-3 \mathrm{~cm}$ long, lanceolate, conspicuously longer than the well-developed petals

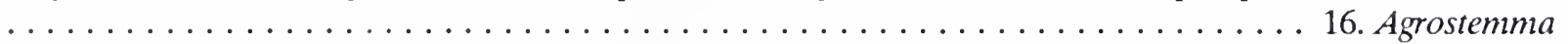

19. Calyx lobes less than $1 \mathrm{~cm}$ long, not greatly exceeding the petals . . . . . . . . . . . . . (20)

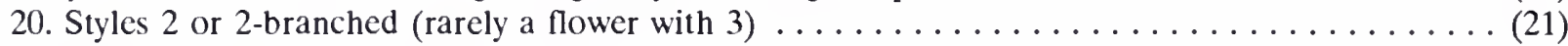

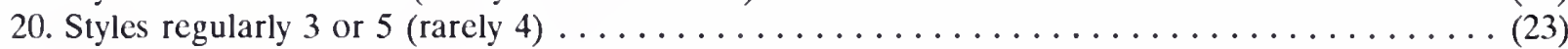

21. Flowers 4-9 (-12) $\mathrm{mm}$ long, borne in diffuse panicles; calyx tube $2-8 \mathrm{~mm}$ long, campanulate or turbinate.

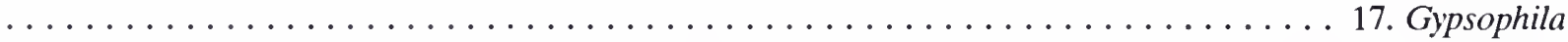

21. Flowers more than $12 \mathrm{~mm}$ long, borne in dense to open cymes; calyx tube, $12-25 \mathrm{~mm}$ long, cylindric to inflated

22. Fruiting calyx strongly inflated with 5 prominent, ribbed angles; petals lacking appendages at the corolla throat; an annual plant from a taproot ...................... Vaccaria

22. Fruiting calyx cylindric to somewhat ovoid, not strongly inflated or angled; petals fringed with append ages at the corolla throat; a rhizomatous perennial ............... . . Saponaria

23. Capsule dehiscing by 5 acute or bifid valves; styles equaling the capsule valves in number (5, rarely 4). .

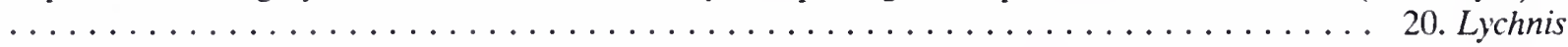

23. Capsule dehiscing by 6 ( 8 or 10$)$ teeth; styles half the number of capsule teeth $(3,4$ or 5$) \ldots 21$. Silene

\section{PARONYCHIA}

Common Names: Whitlow-wort, Silverwort

Authority: Hill, in Scott, Suppl. Chambers Cyclop. 2, 1753 (not Miller, Gard. Dict., Abr. ed., p. 4, 1754)

A genus of up to 100 or more species of mostly slender herbs, distributed widely in the warm, sandy regions of the world.

Description: Plants with bisexual flowers; stigmas 2, sessile, or bifid on a single style; ovary 1, superior or slightly adherent to the calyx tube, bearing a single fertile ovule; fruit a utricle (achene) with a tough pericarp; seed 1, embryo curved; perisperm present; stamens 2-5; perianth a single whorl, or the inner whorl much reduced; petals absent or represented by setae or minute scales; sepals 5, often cucullate and awned, united near the bases, investing all or most of the mature fruit; pedicels numerous, borne in the leaf axils; bracts scarious, often silvery, conspicuous and concealing the flowers; inflorescences dense heads to loose cymes, usually axillary; leaves elliptic to linear, opposite (rarely appearing alternate on the same stem); petioles absent; stipules present, usually conspicuous and scarious; stems capillary to wiry, often much-branched, erect or ascending (in ours); root system an annual taproot (in ours) or fibrous and perennial.

\section{KEY TO SPECIES}

1. Stems pubescent; the upper branches often densely congested or tufted; most sepals strongly 3-ribbed, bearing a distinct mucro (awn) subterminally $\ldots \ldots \ldots \ldots \ldots \ldots \ldots \ldots \ldots \ldots \ldots$ fastigiata

1. Stems glabrous; upper branches not conspicuously congested or tufted; sepals weakly ribbed, mucros lacking or vestigial and inconspicuous

2. P. canadensis 


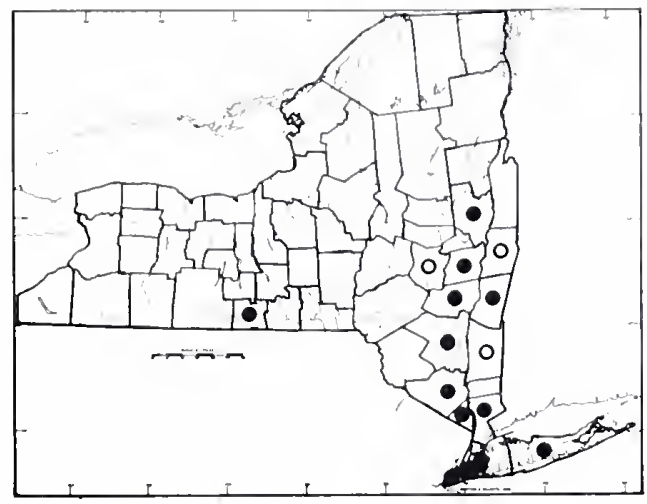

1. Paronychia fastigiata (Raf.) Fern.

Conmon Names: Forked Chickweed

Type Description: Rafinesque, Atl. Jour. 16, 1832

Synonyms: Anychia divaricata Raf., A. polygonoides Raf.

Origin: A native of eastern North America

Habitats: Dry, rocky, often shale habitats, sunny hilltops and fields, open oak woodlands, ditches, creek beds quarries and roadsides

Ilabit: Erect annual herbs, densely branching Flowering: July-September

Fruiting: July-November

General Distribution: Massachusetts to Minnesota \& lllinois south to Mexico, Texas and Georgia Description: Plants with bisexual flowers; stigmas 2, minute capping the style branches; style bifid for about half its length, persistent in fruit, ca. $0.2 \mathrm{~mm}$ long; ovary ovoid, less than $1 \mathrm{~mm}$ long; fruit an obovoid, thin-walled utricle, $0.8-1.4 \mathrm{~mm}$ long and broad, brownish, the surface minutely papillose, shattering to reveal the single seed; seed $0.7-1.0 \mathrm{~mm}$ long and broad, plump, glossy brown; stamens 5 , ca. $0.4 \mathrm{~mm}$ long; anthers globose, golden; filaments slender, free; perianth consisting of a calyx whorl and a fringe of bristles; petals absent, represented by a minute staminodial fringe, usually of 5 bristles; sepals 5 or 6 , fused only at the base of the ovary, greenish to brown, persistent in fruit, partially or wholly enclosing the fruit, usually prominently 3 -ribbed, $0.9-1.6 \mathrm{~mm}$ long, ca. $0.5 \mathrm{~mm}$ broad, cucullate, the adaxial surface sometimes puberulent, almost always with a distinct subterminal awn or hyaline mucro; pedicels absent or present, up to $0.3 \mathrm{~mm}$ long; peduncles up to $2 \mathrm{~mm}$ long, bracteate, sometimes with short, curved hairs; inflorescence diffuse, a sparsely tufted to massive fastigiate aggregate of flower clusters borne almost entirely in the crowded upper branch and leaf axils; bracts of the inflorescence hyaline, lanceolate with caudate tips, 0.3-1.8 mm long, subtending and sometimes exceeding the sepals in length; leaves opposite, narrowly elliptic to lance-obovate, much reduced and crowded on upper branches, well-developed on the main stem axis, up to $2.3 \mathrm{~cm} l o n g, 0.6 \mathrm{~mm}$ broad, but usually much smaller, margins entire or with a few minute teeth and mucros at or near the acute to obtuse tips, bases tapering to a poorly defined petiole; stipules present, borne opposite the leaves, hyaline $2-3$ (4) $\mathrm{mm}$ long, ca. $1 \mathrm{~mm}$ broad; stems much-branched above the main axis, erect-ascending with (a few) up to hundreds of spreading, branched and tufted axes, $3-35 \mathrm{~cm}$ tall, the crown of the herb sometimes very dense, shallowly convex or flat-topped; root system a slender to thick, tough, annual taproot $(2 \mathrm{n}=32,36)$.

Infraspecific Variation: A number of intergrading varieties have been named, but their recognition is not recommended here. Some populations ranging from Pennsylvania southward in the Appalachians have a somewhat prostrate growth habit and short cauline leaves [var. pumila (Wood) Fern.]. Other taxa have been based on bract length and length of the mucro of the sepal, both of which show a great deal of variation between and within populations. 


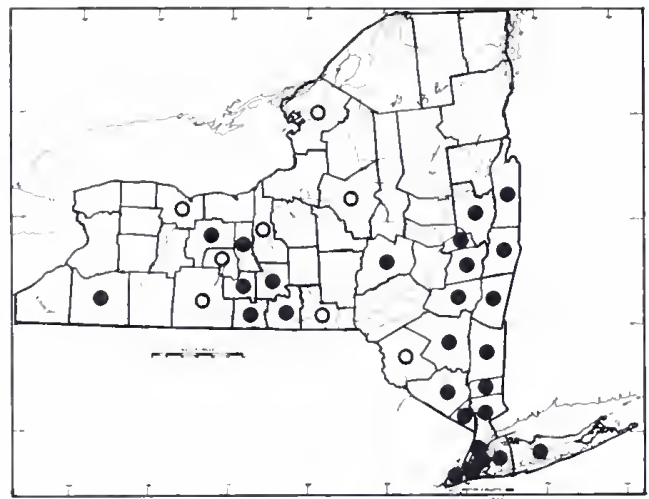

\section{Paronychia canadensis (I..) Wood}

Common Names: Forked Chickweed, Whitlowwort, Nailwort

Type Description: Linnaeus, Species Pl. I, p. 90, 1753

Synonyms: Achyranthes dichotoma L., Anychia canadensis (L.) BSP., A. dichotoma Michx., not (L.), P. dichotoma (Michx.) A. Nels, Queria canadensis $\mathrm{L}$.

Origin: A native of eastern North America

Ilabitats: Oak woodlands, clearings and rocky slopes, cliffs, shores, and other disturbed, gravelly places

IIabit: Erect, much-branched annuals

Flowering: (June) July-October

Fruiting: July-November

General Distribution: New Hampshire to Minnesota and Kansas, south to Arkansas

Description: Plants with bisexual flowers; stigmas 2, minute capping the style branches; style bifid for ca. 2/3 its length, or occasionally 2 separate styles, persistent in fruit, ca. $0.2 \mathrm{~mm}$ long; ovary ovoid, less than $1 \mathrm{~mm}$ long; fruit a spheroid, thin-walled utricle, 0.8-1.1 $\mathrm{mm}$ long and broad, glistening red-brown, the surface minutely papillose, glandular, shattering to reveal a single seed; seed 0.7-0.9 mm long and broad, plump, glossy brown; stamens 2-5, ca. $0.4 \mathrm{~mm}$ long; anthers globose, golden; filaments free; perianth 1-2 whorls with true petals lacking; petals absent or represented by a minute staminodial fringe of 3-5 flattened bristles; sepals 5 (6), fused into a shallow cup at base, greenish to brown or hyaline-margined, persistent in fruit, partially enclosing, but usually not exceeding the fruit, flat to prominently cucullate (never strongly 3-veined), 0.5-0.9 $\mathrm{mm}$ long, ca. $0.3 \mathrm{~mm}$ broad, the adaxial surface glabrous, glandular-punctate, sometimes with a subterminal bulge, but lacking a distinct mucro; pedicels present or absent, up to $2 \mathrm{~mm}$ long; peduncles 3-8 (12) $\mathrm{mm}$ long, usually glabrous; inflorescence diffuse, the small flower clusters borne mostly in the upper branch and leaf axils; bracts of the inflorescence hyaline, lanceolate with acute to caudate tips, 0.3-0.6 mm long, subtending the sepals; leaves opposite (occasionally alternate or one leaf of the pair reduced), glandular, particularly beneath, lance-elliptic to obovate, much reduced in size on upper branches, well-developed on the main stem axis, up to $1.8 \mathrm{~cm}$ long, $0.8 \mathrm{~mm}$ broad, but usually less than $1 \mathrm{~cm}$ long, margins entire, tips acute to obtuse, sometimes with a mucro, bases tapering to a poorly defined petioles $1-2$ (4) mm long; stipules present, often opposite the leaves (or several stipule-like organs borne at a node) hyaline 1-2 mm long, ca. $0.4 \mathrm{~mm}$ broad; stems slender, much-branched above, forking and spreading toward the tips, with up to hundreds of branching axes, the crown of the herb shallowly convex or flat-topped, the main axis erect-ascending, $2-30(40) \mathrm{cm}$ tall, tough, with minute, vertical, corky striations; root system a straight to gnarled, woody, annual taproot. 
Note: Ephemeral occurrences of two species of the closely related genus, Herniaria, have been recorded in the vicinity of New York City: H. cinerea DC. was collected once near a Yonkers wool mill, and $H$. glabra L. was found once in the Bronx. Herniaria, a genus of up to 50 species native to the Mediterrancan Region, is doubtfully taxonomically distinct from Paronychia. The minute flowers may be consistently 4-merous or both 4- and 5-merous on the same plant, depending upon the species. Plants of both species reported from New York State have bunchy, procumbent growth habits.

\section{SPERGULARIA}

Common Names: Sand-spurrey, Spurry

Authority: J. \& C. Pres1, Fl. Cech. 94, 1819

A genus of about 50 species, distributed around the world in maritime and inland, saline areas, mostly in Mediterranean, boreal and temperate climates.

Description: Plants with bisexual flowers; stigmas and styles 3 (rarely 4-5); ovary 1, superior; ovules numerous on a free central placenta; fruit a capsule with 3 (-5) valves; seeds many, sculptured or papillate, winged or unwinged; embryo curved, but not forming a complete ring; stamens (1) 2-10; filaments frec; anthers globose; perianth of 2 distinct whorls; petals 5, entire; sepals 5, divided to near the base, persistent in fruit, partially to wholly enclosing the capsule; pedicels and peduncles slender and wiry to short and succulent; inflorescence loosely cymose, the flowers borne in the upper leaf and stem axils; bracts often leaf-like; leaves linear, opposite or fascicled on short-shoots, sometimes succulent; petioles obscure or absent; stipules present, scarious, united at their bases into a shallow sheath; stems wiry to semi-succulent, often much-branched, erect or widely spreading from a central annual stem axis or short, perennial caudex; roots ranging from annual taproots to woody, perennial stocks.

\section{KEY TO SPECIES}

1. Most leaves with strongly mucronate or aristate tips; very short shoots with tufted leaves borne at many nodes; stipules lanceolate (to narrowly triangular); seeds $0.4-0.6 \mathrm{~mm}$ long, never winged, the surfaces

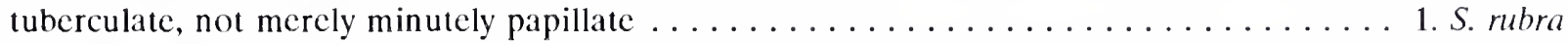

1. Most leaves short-mucronate or blunt-tipped, not strongly tufted at the nodes; stipules triangular to deltoid or broadly obtuse; seeds winged or unwinged, (0.6) 0.7-1.4 mm broad, the surfaces not tuberculate (sometimes with stalked or minute papillac) . . . . . . . . . . . . . . . (2)

2. Stamens 8-10 (rarely 6); capsules mostly 6-8 mm long at maturity; (plants occurring mostly inland near

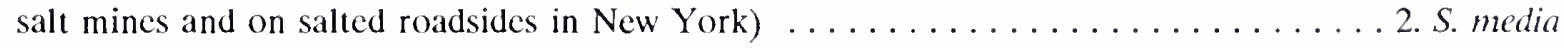

2. Stamens 2-5; capsules mostly 3-5 mm long; (plants found mostly in coastal salt marshes in New York,

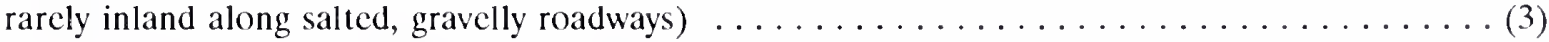

3. Sheaths of the middle and upper nodes miter-like, the basal cup bearing pair of triangular, stipular lobes that are acute to acuminate (the tips sometimes lacerate, toothed or bifid); seeds mostly $0.6-0.8 \mathrm{~mm}$ long $\ldots \ldots \ldots \ldots \ldots \ldots \ldots \ldots \ldots \ldots \ldots \ldots \ldots \ldots \ldots \ldots \ldots \ldots \ldots \ldots \ldots \ldots$ 3. Salina

3. Sheaths of the middle and upper nodes cup-like, shallowly tubular, the stipular lobes short, broadly deltoid to rounded with obtuse to truncate tips (sometimes lacerate or apiculate); seeds mostly $1.0-1.2 \mathrm{~m} ı \mathrm{~m}$ long 


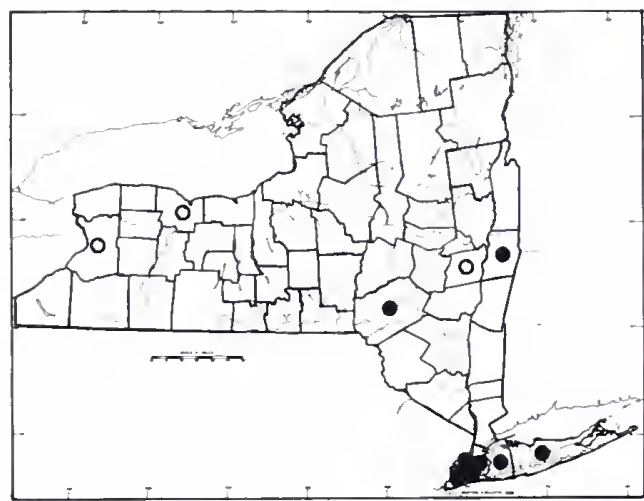

1. Spergularia rubra (L.) J. \& C. PresI

Common Names: Common or Purple Sand-spurry, Sandwort

Type Description: Linnaeus, Species PI. I, p. 423, 1753

Synonyms: Alsine rubra (L.) Crantz, Arenaria rubra L., Buda rubra (L.) Dumort., Lepigonum rubrum (L.) Fries., S. campestris (L.) Aschers., Tissa rubra (L.) Britt.

Origin: A native of Europe

Iabitats: Dry, sandy fields, sunny waste places and cultivated ground as an introduced weed

Habit: Wiry, spreading or decumbent annuals or short-lived perennial herbs

Flowering: May-September

Fruiting: May-November

General Distribution: Newfoundland to British Columbia, south to New Jersey, with reports as far south as Virginia and Alabama (weedy in South America and in its native Europe)

Description: Plants with bisexual flowers; stigmas 3; styles 3, free, minute, linear, not persisting in fruit; ovary 1, superior ovoid to pyriform, ca. $1 \mathrm{~mm}$ long; fruit a 3-valved, smooth, tan capsule, ovoid, 3.1-4.8 mm long, 2.9-4.1 mm broad, about equaling the persistent calyx; seeds many, dark brown, unwinged, 0.4-0.6 mm long, comma-shaped with a dorsal ridge, the surfaces prominently tuberculate with knob-tipped protrusions; stamens 6-10; anthers golden, globose, minute; filaments pale, broader at base, ca. $1 \mathrm{~mm}$ long; perianth of two distinct whorls of 5; petals 2.2-3.4 mm long, ca. $1 \mathrm{~mm}$ broad, cucullate, pale to bright pink, persistent in fruit; sepals ovate to lanceolate, cucullate, $2.6-4.7 \mathrm{~mm}$ long, $1.2-3.0 \mathrm{~mm}$ broad, green with hyaline margins, densely glandular on the abaxial surfaces, persistent and partially enclosing the fruit; pedicels filiform, densely glandular, 2-10 (13) mm long; inflorescence diffuse, a leafy cyme with most flowers borne singly at the upper nodes; bracts linear, green, mucronate, glandular mostly 1-4 mm long; leaves 3-17 (30) mm long, linear and needle-like, not succulent, glabrous or with a few glandular hairs, paired at the nodes and commonly fascicled on axillary short-shoots giving the plants a somewhat tufted appearance; petioles not evident; stipules lustrous, whitish to silvery, scarious, linear to broadly lanceolate, sometimes lacerate or with two or more aristate tips, varying considerably in size up to $5 \mathrm{~mm}$ long and $2 \mathrm{~mm}$ broad at base; stems wiry, puberulent below, increasingly covered with glandular hairs upward, often much-branched, erect, ascending or decumbent, 5-20 (40) $\mathrm{cm}$ long, from a short caudex when perennial; root system a strong, sometimes woody, annual taproot or short-lived, perennial root with wiry lateral branches $(2 \mathrm{n}=18,36,54)$.

Infraspecific Variation: The plants vary mostly in stature, branching density and robustness, all of which seem to be strongly influenced by longevity of the individual. 


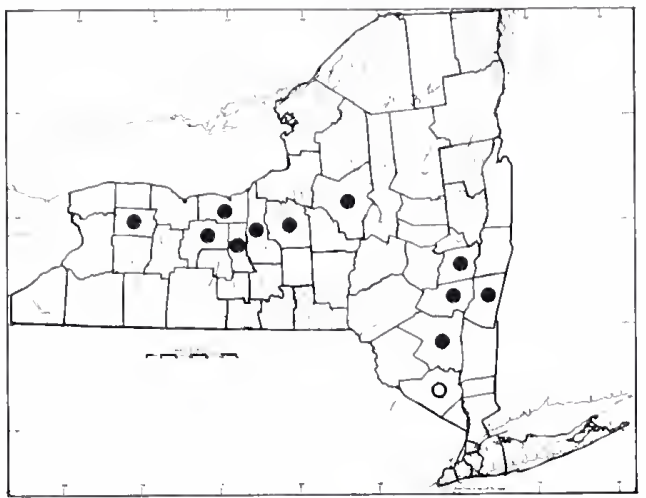

2. Spergularia media (L.) C. Presl ex Griselb. Common Names: Sand-spurry

Type Description: Linnaeus, Species Pl. ed. 2, p. 606,1762

Synonyms: Alsine marginata (DC. ex Lam. \& DC.) Reichenb., A. media (L.) Druce, Arenaria marginata DC. ex Lam. \& DC., A. maritima Steud., A. media L., Buda media (L.) Dumort., Lepigonum medium (L.) Fries., S. alata Wieg., S. marginata (DC. ex Lam. \& DC.) Kittel

Origin: Native to coastal Europe

Habitats: Saline, inland sites, fields and waste places, formerly only around salt mines, but now spreading along some roadsides where highways are heavily salted in winter

IIabit: Coarse, erect, spreading (rarely decumbent) biennial or perennial herbs

Flowering: June-September

Fruiting: Late June-November

General Distribution: A sporadic, European adventive of saline places: upstate New York, Pennsylvania, Ohio,

Michigan, Illinois, Indiana, California and Oregon; also naturalized in Chile, Argentina and Uruguay

Description: Plants with bisexual flowers; stigmas 3; styles 3, minute, linear, free; ovary 1, superior, ovoidcylindric, ca. $1.5 \mathrm{~mm}$ long; fruit a 3-valved, smooth, tan capsule, semi-transparent, elliptic, 5.8-9.2 mm long, $3-5 \mathrm{~mm}$ broad, exserted from the calyx; seeds many, brown, lusterless, 0.6-0.8 $\mathrm{mm}$ long (excluding wing), comma-shaped with a poorly defined dorsal ridge, usually alate, the wing $0.2-0.3 \mathrm{~mm}$ broad, completely encircling the seed, hyaline, pleated, with an entire to shallowly fimbriate margin; stamens (6) 8-10; anthers globose, golden; filaments pale, expanded toward the base, ca. $1 \mathrm{~mm}$ long; perianth of two distinct, free whorls of 5; petals white or pink with whitish margins and bases, narrowly lanceolate to lance-ovate, $2.2-4.5 \mathrm{~mm} l o n g$, 0.4-0.8 mm broad, with cucullate tips, persistent in fruit; sepals $3-7(8) \mathrm{mm}$ long $1-4 \mathrm{~mm}$ broad, narrowly to broadly ovate with acute to bluntly cucullate tips, green or pink-tinged with hyaline margins, densely hirsuteglandular on the abaxial surface or sometimes glabrous, persistent, partially enclosing the exserted fruit; pedicels 2-22 mm long, slender, with glandular hairs or glabrous; inflorescence diffuse, leafy, cyme-like, the flowers borne mostly in the upper leaf axils; bracts like the leaves but shorter and often sparsely to densely glandular pubescent; leaves $1-4(5) \mathrm{cm}$ long, linear, needle-like, the tips blunt to acute or weakly mucronate, glabrous (or with very few glandular hairs); petioles absent; stipules broadly to narrowly triangular, hyaline, glaucous, 2,3-6.2 mm long, tips acute to acuminate (rarely obtuse), sometimes toothed or bifid; stems 3-30 (40) $\mathrm{cm}$ tall, often spreading, sparsely to profusely branched from a short, tough caudex, the nodes somewhat swollen, internodes glabrous to densely glandular-pubescent in the upper nodes of the inflorescence; root system a tough, annual or perennial taproot with fibrous lateral branches $(2 \mathrm{n}=36)$. 
Infraspecific Variation: Unwinged seeds are occasionally found in the same capsule with winged ones. The upper stems, pedicels and sepals are usually glandular-pubescent, but glabrous plants occur in both Europe and North America, and these tend to be diminutive in stature. Although this species is thought to be a European introduction, our plants do not conform completely with the species description in Flora Europaea (Monnier \& Ratter In: Tutin et al., 1964). Therefore, only those plants growing in northeastern North America are treated in the preceding description. Characteristics listed here for the American plants are largely in agreement with the treatment of Rossbach (1940). Ours have petals much like those of $S$. salina ("S. marina"), shorter than the sepals and sometimes pinkish rather than white. The stipules are mostly acute or acuminate, and, while the European treatment (ibid.) specifically states: "not acuminate," this does not hold true consistently, even for their native plants. The predominantly winged seeds, larger capsule size and greater stamen number of $S$. media are useful characters in distinguishing it from $S$. salina in North America, if not elsewhere; further comparison of the taxa worldwide would almost certainly be enlightening.

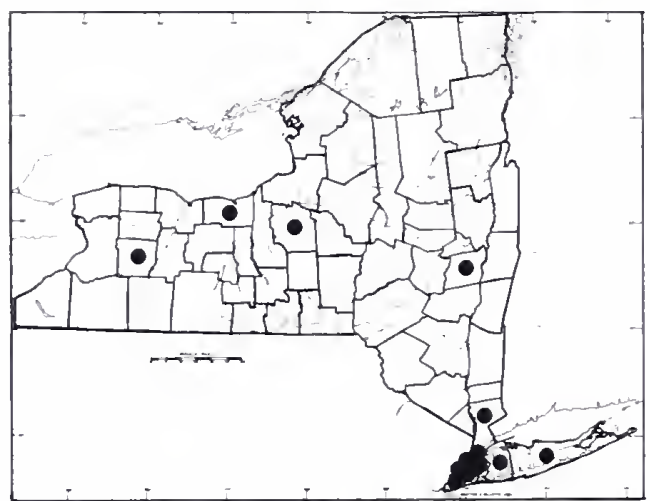

3. Spergularia salina J. \& C. Presl

Common Names: Saltmarsh Sand-spurry

Type Description: J. \& C. Presl, Fl. Cech., p. 95, 1819

Synonyms: Alsine maritima Pall., Arenaria rubra $\beta$ marina L., A. marina Allioni, Buda marina (L.) Dumort., Lepigonum caninum Leffler, L. marinum (L.) Kindb., Spergula salina (J. \& C. Presl) Dietr., Spergularia canina (Leffler) Leffler, S. leiosperma (Kindb.) F. Schmidt, S. marina (L.) Griseb., S. tenue Greene, Tissa marina (L.) Britt.

Note: This species appears in most North American literature as $S$. marina (L.) Griseb., a name based on a transfer of the infraspecific taxon, $\beta$ marina L. 1 have chosen to recognize the first-published epithet at the species level.

Origin: Native to coastal Europe

Irabitats: Saline, mostly coastal habitats often along shores, beach margins, and in salt marshes, with a dwarf race that rarely spreads inland along gravelly, salted roadways.

Ilabit: Spreading annual herbs with taproots

Flowering: Late May-October

Fruiting: June-November

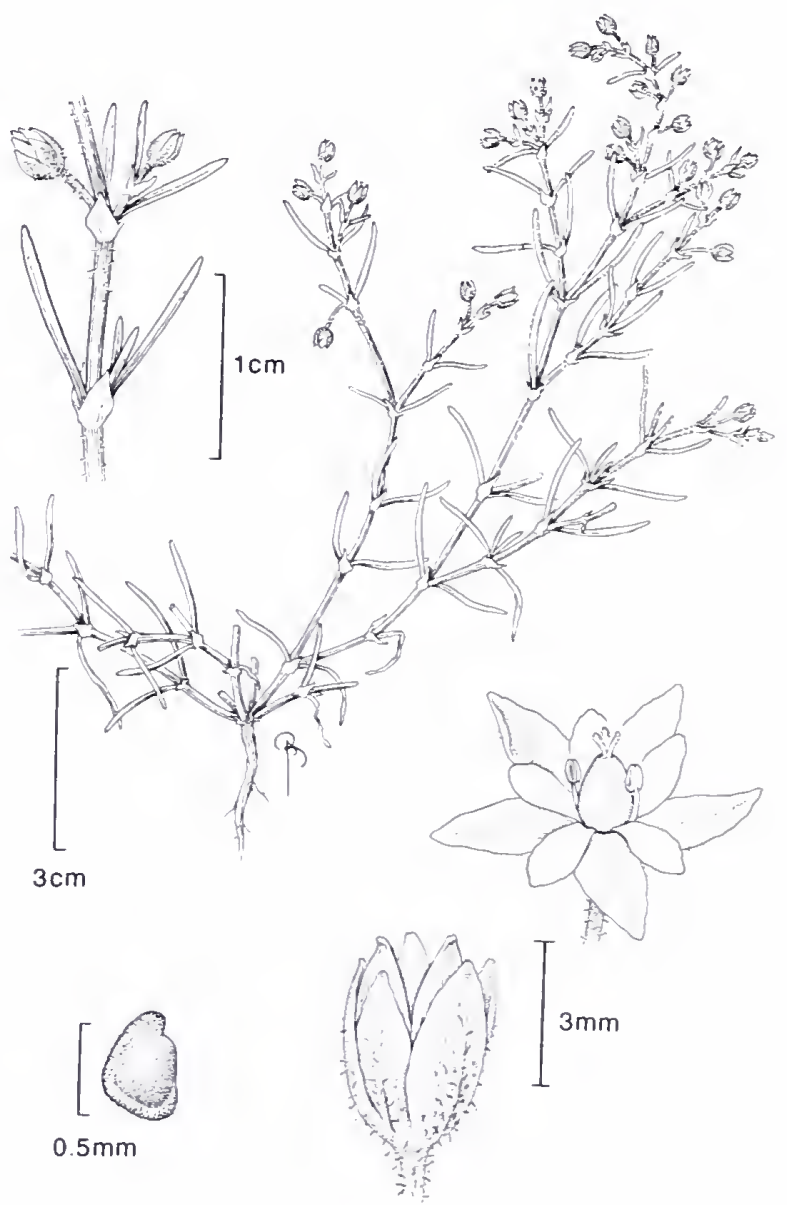


General Distribution: Introduced throughout much of North America in saline coastal areas, widely scattered inland in waste and alkaline places, Quebec to British Columbia south to Mexico and the Caribbean Islands (also Brazil and Uruguay)

Description: Plants with bisexual flowers; stigmas 3; styles 3, minute, linear, free; ovary 1, superior, cylindricovoid, ca. $1 \mathrm{~mm}$ long; fruit a 3-valved, smooth, pale tan capsule, elliptic to ovoid, (2) 3-5 (6.4) mm long, 1.8-4.2 $\mathrm{mm}$ broad, exserted from the calyx $1-2 \mathrm{~mm}$; seeds many, medium to dark reddish-brown, smooth or with stalked papillae, most often along the dorsal ridge, 0.6-0.8 mm long (excluding wing), comma-shaped, usually not alate, the wings (when present) $0.1-0.2 \mathrm{~mm}$ broad, hyaline, pleated, with an entire to shallowly fimbriate margin, friable (sometimes reduced to a partial wing or a few rib-like fragments); stamens (1) 2-3 (-5); anthers globose, golden; filaments pale, expanded toward the base, ca. $0.8 \mathrm{~mm}$ long; perianth of two distinct, free whorls of 5; petals totally pink or with whitish margins and bases, narrowly lanceolate to lance-ovate, (1) 1.43.8 (4.1) $\mathrm{mm}$ long, 0.2-0.8 (1.1) $\mathrm{mm}$ broad, with blunt to acute tips, persistent in fruit; sepals 1.8-3.8 (4.2) $\mathrm{mm}$ long, 1-3 mm broad, narrowly to broadly ovate with acute to blunt-cucullate tips, green or pink-tinged with hyaline margins, densely hirsute-glandular on the abaxial surfaces, or sometimes glabrous, persistent, partially enclosing the exserted fruit; pedicels 1-23 mm long, slender, covered with glandular hairs (rarely glabrous); inflorescence diffuse, leafy, cyme-like, the flowers borne mostly in the upper leaf axils; bracts like the leaves but shorter and often sparsely to densely glandular pubescent; leaves (0.3) 1-3 (4) cm long, linear, needle-like, the tips blunt to acute or very weakly mucronate, glandular-pubescent or glabrous; petioles absent; stipules triangular to broadly deltoid, hyaline, whitish, 2,3-6.2 $\mathrm{mm}$ long, tips acute to acuminate (rarcly obtuse), sometimes toothed or bifid; stems 1-25 (34) cm tall, often spreading, sparsely to profusely branched, the nodes somewhat swollen, internodes glabrous to densely glandular-pubescent in the upper nodes of the inflorescence; root system an annual taproot $(2 \mathrm{n}=36)$.

Infraspecific Variation: The seeds of $S$. salina may be wholly or partially winged or wingless, with smooth or papillate surfaces. In Europe unwinged seeds have been attributed partially to adaptation of populations to disturbed habitats (Sterk, 1969d), but wing variations may vary greatly between the seeds produced within a single capsule. Spergularia tenue Greene is based on California plants distinguished morphologically by their much-branched inflorescences with very small sepals, petals and capsules. They are said to occur with populations of more typical plants of the species, but to flower and fruit earlier. Rossbach (1940) treated this group as $S$. marina var. tenue (Greene) Rossbach. Diminutive plants recently found in New York State are possibly referable to this taxon, as discussed under the following heading.

Taxonomic Note: Spergularia tangerina P. Monnier, described from the Iberian Peninsula of Spain in 1964, was based on very similar characteristics to those of $S$. tenue Greene. If these taxa are determined to be equivalent, Greene's name, $S$. tenue, based on American plants, would, ironically, take precedence. Biosystematic studies by Monnier (1975b) indicated that "S. tangerina" is possibly ancestral to widespread $S$. salina. Thus, certain North American populations of $S$. salina may be exhibiting atavism under strong selective pressure. Plants recently found on salty roadsides in New York State and elsewhere in the northeast have similar (even smaller) flower parts than $S$. tangerina, along with very slender stems, but they lack profusely-branched inflorescences. Rare New York specimens of these tiny annuals have flowers with 2-3 stamens, petals 0.9-1.3 mm long, sepals 1.9-3.5 $\mathrm{mm}$ long, and a mature capsule $2.0-3.4 \mathrm{~mm}$ long, equaling or barely exceeding the calyx. The seeds are pale brown, unwinged and $0.5-0.8 \mathrm{~mm}$ long, with scattered, stalked papillac. Such plants do not match descriptions of any European taxa yet seen in the literature. In the light of studies on reduction series within S. salina as a whole (Sterk, 1968-1972), these variants are probably best treated as members of a diminutive race or phenotypic modification series within a single polymorphic species. Their gravelly roadside habitats are sustained by severe and continued disturbance, including summer grading and winter salting, with nutrients undoubtedly in poor supply. 


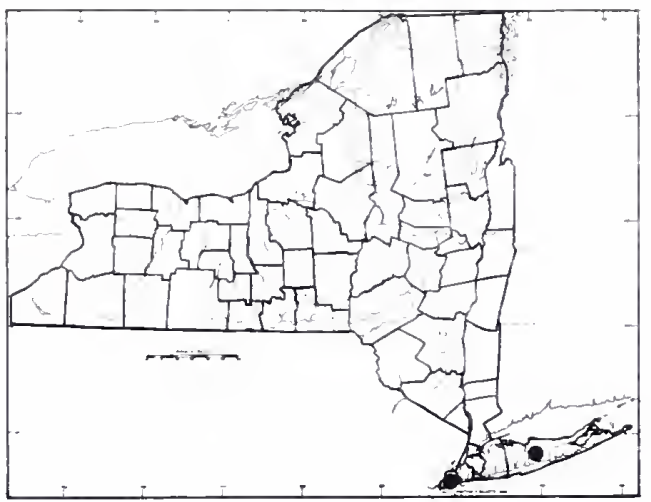

4. Spergularia canadensis (Pers.) D. Don

Common Name: Northern Sand-spurry, Bed Sandwort

Type Description: Persoon, Syn. vol. 1, p. 504, 1805 Synonyms: Alsine canadensis (Pers.) House: Arenaria canadensis Pers., Buda borealis S. Wats., Spergula canadensis (Pers.) Dietr., Tissa canadensis (Pers.) Britton

Origin: A native of coastal North America

Habitats: Cold, windy coastlines in saline, often acidic, muck or sand

IIabit: Decumbent, fleshy, annual herbs with slender taproots

Flowering: June-October

Fruiting: June-November

General Distribution: Mostly boreal and arctic coastlines in northeastern and northwestern North America: Newfoundland south to Connecticut (formerly New York), coastal Alaska and British Columbia south to California

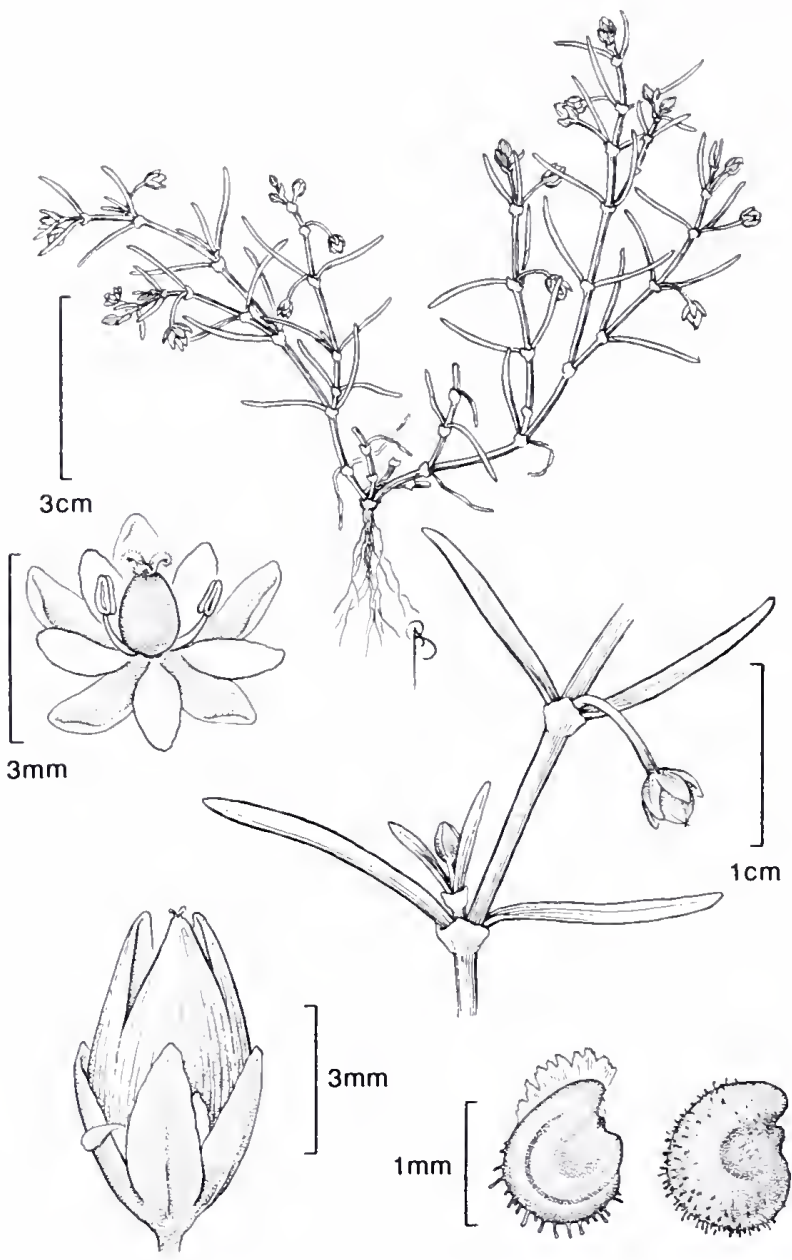

Rarity Status: Probably extirpated from the two known sites in New York State. Ranked by the New York Natural Heritage Program as G5 (globally secure), SX (State extirpated), with no current protection under State law. One site was known on Long Island and one on Staten Island (1880s).

Description: Plants with bisexual flowers; stigmas 3; styles 3, minute, linear, free; ovary 1, superior, ovoidcylindric, ca. $1.5 \mathrm{~mm}$ long; fruit a 3-valved, smooth, pale tan capsule, elliptic to ovoid, 3.3-5.4 mm long, 1.8-3.8 $\mathrm{mm}$ broad, exserted from the calyx up to $2.6 \mathrm{~mm}$; seeds many, medium to dark brown, smooth, slightly crested or with stalked papillae that are most abundant along the plump, dorsal ridge, (0.8) 1.0-1.3 (1.4) $\mathrm{mm}$ long (excluding wing), comma-shaped, unwinged or with wings $0.1-0.3 \mathrm{~mm}$ broad, hyaline, pleated, with an entire to shallowly toothed or wavy margin, friable (sometimes reduced to a partial wing or a few rib-like fragments); stamens 2-5; anthers globose, golden; filaments pale, expanded toward the base, ca. $0.7 \mathrm{~mm}$ long; perianth of two distinct, free whorls of 5; petals white or pink, narrowly lanceolate to lance-ovate, (0.8) 1.4-2.6 mm long, 0.2-0.8 (1.1) mm broad, with blunt to acute tips, persistent in fruit; sepals $1.8-3.2 \mathrm{~mm}$ long, 1-2 mm broad, narrowly to broadly ovate with acute to blunt, cucullate tips, green or pink-tinged with hyaline margins, glabrous, persistent, only partially enclosing the strongly exserted fruit; pedicels $4-16 \mathrm{~mm}$ long, often reflexed in fruit, glabrous (rarely sparsely glandular); inflorescence diffuse to dense, leafy, cyme-like, the flowers borne mostly in upper leaf axils; bracts like the leaves but shorter; leaves $0.6-4.7 \mathrm{~cm}$ long, linear, fleshy, glabrous, the tips blunt; petioles absent; stipules broadly deltoid to obtusely rounded or almost completely fused, comprising only the cup of the sheath, hyaline, less than $1 \mathrm{~mm}$ long, tips very obtusely pointed or rounded, (sometimes apiculate, bifid or with tiny teeth); stems decumbent, $2-35 \mathrm{~cm}$ long, sparsely to profusely branched, the nodes somewhat swollen, internodes glabrous; root system an annual taproot $(2 n=36)$. 
Infraspecilic Variation: Varicty occidentalis Rossbach, ranges from California to British Columbia; it differs from the typical variety in having a more ascending habit, larger stipules, a less exserted capsule and some glandular pubescence.

\section{SPERGULA}

Common Name: Spurrey

Authority: Linnacus, Species Pl., p. 440, 1753

A genus of about 5 species, native to the Old World. Spergula arvensis L. is an aggressive weed of cultivated fields that has become a common naturalized weed in New York State and around the world. Two other spurreys, $S$. pentandra L. and $S$. morrisonii Bor., are naturalized in eastern North America as far north as southern New Jersey.

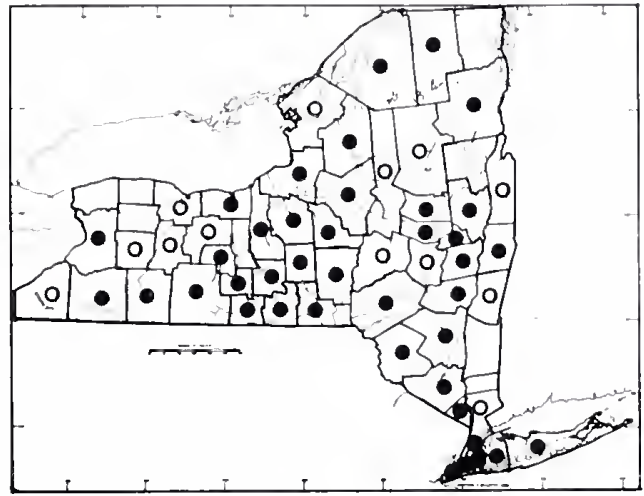

1. Spergula arvensis $\mathrm{L}$.

Common Names: Corn-spurry or Spurrey, Povertyweed, Pine-cheat, Cow-quake, Pick-purse, Yarr

Type Description: Linnacus, Species Pl. I, p. 440, 1753

Synonyms: S. ariensis var. sativa (Bönn.) Mert. \& Koch, not Reichenb., $S$. linicola Boreau, $S$. maxima Weihe, S. sativa Bönn., S. vulgaris Bönn.

Origin: A native of Europe

Ilabitats: Sandy and gravelly soils, especially as a weed of cultivated ground, waste places, roadsides and railroad tracks

Ilabit: Slender, ascending annuals from taproots

Flowering: June-September

Fruiting: June-November

General Distribution: Native to Europe, a weed in North America from Newfoundland to Alaska, south to California, Louisiana and Florida

Description: Plants with bisexual flowers; stigmas 5, papillate; styles 5, minute, free to near the base, persistent until dehiscence; ovary ovoid, ca. $1 \mathrm{~mm}$ long; fruit a 5 -valved capsule, $3.8-5.4 \mathrm{~mm}$ long, $3.5-4.4 \mathrm{~mm}$ broad, spheroid to elliptic or ovoid, only slightly exserted from the perianth, glossy tan, the valves opposite the sepals; seeds several to many, frequently polyembryonic, $0.9-1.6 \mathrm{~mm}$ broad, ca. $0.7 \mathrm{~mm}$ broad, lenticular, with a very narrow, circumferential, pale tan wing, seed surface dull, rough, dark brown to ebony, often with scattered, pale, glandular papillac; stamens 5-10; anthers minute, golden; filaments pale, 1-2 mm long; perianth of 2 distinct whorls; petals 5, free, white, narrowly to broadly ovate, $1.5-3.6(5) \mathrm{mm}$ long, 1-3 mm broad, with acute to obtuse tips, persistent; sepals 5, free, ovoid, 2.6-4.6 (5.2) $\mathrm{mm}$ long, $2-3 \mathrm{~mm}$ broad, with acute to obtuse tips, 
green with narrow hyaline margins, sparsely to copiously glandular-pubescent on the adaxial surfaces, persistent, almost completely enclosing the capsule at maturity; pedicels slender, mostly $1.0-2.5 \mathrm{~cm}$ long, glandular pubescent to glabrescent, often reflexed in fruit; peduncles much like the pedicels; inflorescence a diffuse, often dichotomously branched, panicle, terminal, or with a few small axillary branches, totaling up to $1 / 2$ the plants height; bracts scarious, lance-ovate to cordate with acute tips, ca. $1 \mathrm{~mm}$ long; leaves whorled, appearing fascicled or tufted on the short shoots at the nodes, linear, the lower ones grooved near the base, $1-5$ (6) $\mathrm{cm}$ long, $0.5-1.3 \mathrm{~mm}$ broad, sometimes viscid-glandular, usually glabrous, dull to bright green; petioles absent; stipules ovate-cordate to triangular-acute, $1-2 \mathrm{~mm}$ long, hyaline; stems simple to much-branched, erectascending, slender, grooved, glabrescent to moderately glandular-pubescent, $5-45(70) \mathrm{cm}$ tall; root system a slender to relatively stout, annual taproot with bunchy lateral branches [ $2 \mathrm{n}=18$ (36)].

Infraspecific Variation: Plants sometimes segregated as S. arvensis var. sativa (Bönn.) Reichenb. are descended from escaped cultivars. They are dull green and viscid and lack glandular papillae on the seeds. Characters once considered to be of taxonomic significance, such as stem pubescence and seed coat papillae have been shown to vary clinally (New, 1958).

Importance: These plants get the name corn-spurry from their aggressive, weedy invasion of grain fields, in this case referring to wheat, the "corn" of pre-Columbian Europe. Although the plants contain bitter and poisonous saponins, they have been grown successfully for centuries as fodder for farm animals. An 18th century report claims that spurry was eaten by humans in times of famine in northern Europe, dried, ground and baked into wheat bread in small quantities as an adulterant.

Note: Spergula morrisonii Boreau was reported once as a waif in the vicinity of Rochester early in the 20th century.

\section{SCLERANTHUS}

Common Names: Knawel, German Knotgrass

Authority: Linnacus, Species Pl. I, p. 406, 1753

A genus of 3-12 species, depending on the degree of taxonomic splitting employed when treating the $S$. perennis and $S$. annuus complexes. The plants are native to Eurasia and are commonly weedy in temperate climates around the world.

\section{Scleranthus annuus L.}

Common Names: Knawel, German Knotgrass, Parsley-piert, Gravel Chickweed,

Type Description: Linnaeus, Species Pl. I, p. 406, 1753

Origin: A native of Europe

Synonyms: $S$. annuus ssp. ruscinonensis (Gillot \& Coste) P. Sell, S. uncinatus Schur

Ilabitats: Open areas, gravelly roadsides, paths, railways, and also more natural areas such as limy forest clearings and sand plains

Habit: Spreading, with tufted, much-forked stems; annuals from taproots

Flowering: (March) May-October

Fruiting: May-December

General Distribution: Northern Newfoundland to Minnesota, south to Indiana and along the Coastal Plain to Florida

Flowering: (March) May-October

Fruiting: May-December

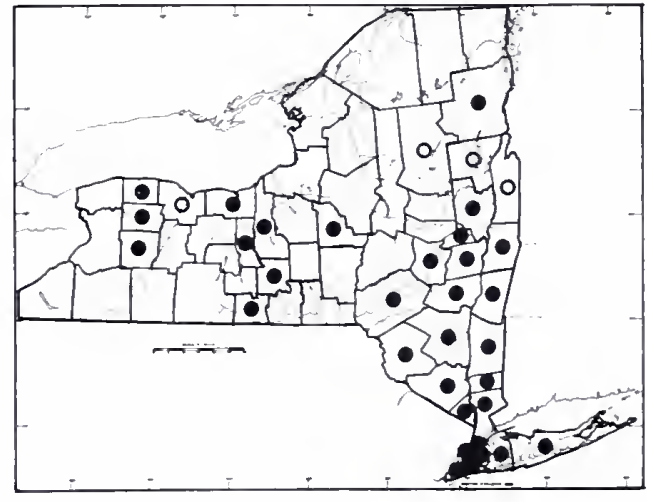


General Distribution: Northern Newfoundland to Minnesota, south to Indiana and along the Coastal Plain to Florida

Description: Plants with bisexual flowers; stigmas 2, terminal, papillose; styles 2, filiform, 0.7-0.9 mm long, hyaline; ovary 1 , bearing a single ovule on a basal placenta (rarely 2 ), the ovary partially inferior, fused to a hypanthium; fruit $1.2-1.7 \mathrm{~mm}$ long, ca. $1.3 \mathrm{~mm}$ broad, a utricle (nut), remaining within the persistent hypanthium, bearing 1 (rarely 2) seeds; seed 1 (very rarely 2 ), spheroid to lenticular, beaked, tan, ca. $0.8 \mathrm{~mm}$ long; stamens $4-10$, minute, adnate to a ring-like septum at the junction of the fruit and hypanthium; anthers globose, golden; filaments linear, straight or inwardly curved; perianth a perigynous cup, fused to the gynoecium for $2 / 3$ or more of its length, bearing a whorl of free perianth lobes; petals absent; sepals (perianth lobes) 5 , perigynous, $1.0-2.3$ (3) $\mathrm{mm}$ long, 0.3-0.9 $\mathrm{mm}$ broad at base, lanceolate with acute often abruptly cucullate tips, green with very narrow (ca. $0.1 \mathrm{~mm}$ ) scarious margins, mostly glabrous, but with a few septate hairs at the hypanthial base; pedicels very short, often less than $1 \mathrm{~mm}$, ensheathed in the base of a floral bract, or flowers sessile; peduncies up to $1.5 \mathrm{~cm}$ long, pilose, with septate hairs that are somewhat retrorse and borne mostly along one side of the peduncle; inflorescence diffuse throughout the plant, with axillary and terminal clusters of 2-4 flowers; inflorescence bracts much like the leaves, often exceding the flowers, even in the short-bracted, terminal clusters; leaves opposite, linear, 3-8 (13) $\mathrm{mm}$ long, groovy, green, acute to obtuse tipped, the margins gradually broader, scarious and ciliate toward the base where they are flared and connate, clasping the nodes; petioles and stipules absent; stems terete, glabrescent to densely retrorse-pilose, branched from near the base, ascending, 2-12 (26) $\mathrm{cm}$ long; root system an annual (biennial) taproot with matted lateral roots $(2 \mathrm{n}=22,44)$.

Infraspecific Variation: Our plants are do not conform well with any described European subspecies. They have very small fruits like ssp. ruscinonensis (Gillot \& Coste) P. Sell, but the sepals are usually spreading and only occasionally connivent, as in the typical subspecies. In many flowers of some individuals, the boat-like (cucullate) apices of the sepal tips are curved abruptly inward and hook-like, the only character used to distinguish $S$. uncinatus Schur in Europe. In North America, the plants seem to comprise a single, slightly polymorphic species lacking in consistent characters useful in segregating taxa, even at the infraspecific level. Importance: A weed of grain fields, particularly wheat, oats and barley; probably introduced a number of times through European seed sources.

\section{HONCKENYA ${ }^{1}$}

Common Name: Seabeach Sandwort

Authority: Ehrhart, Neues Mag. Acrzte 5, p. 193, 1783

${ }^{1}$ Note: The common use of a spelling variation, Honkenya, in the literature was based on Ehrh., Beitr. vol. 2 (1788), incorrectly assumed to be the earliest citation for the generic name.

A single, polymorphic species, historically included in Arenaria. Honckenya is a conspicuous, succulent, seaside plant, mostly of boreal and arctic shores, with a range that encircles the Northern Hemisphere. 


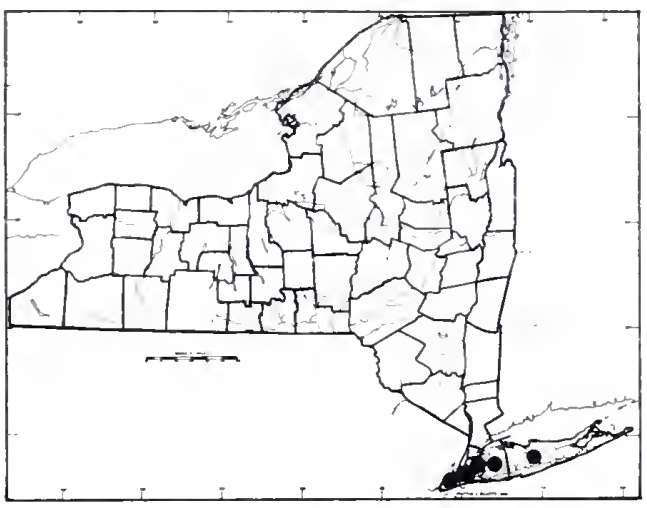

1. Honckenya peploides (L.) Ehrh. ssp. robusta (Fern.) Iultén

Common Names: Seabeach Sandwort, Sea Chickweed, Sea Purslane, Beach-parsley

Type Description: Linnaeus, Species Pl., p. 423, 1753

Synonyms: Ammodenia peploides (L.) Rupr., $A$. maritima (Raf.) Bickn., $A$. peploides var. maritima (Raf.) Stone, Arenaria peploides L., $A$. peploides var. robusta Fern., (Honkenya)

Origin: A native of arctic seashores; ssp. robusta is eastern North American

Ilabitats: Maritime sands: dunes, beaches, saltmarshes, inlets and pond shores

IIabit: Procumbent to decumbent, perennial, matforming herbs

Flowering: May-September

Fruiting: June-October

General Distribution: The species range is arcticcircumboreal; ssp. robusta occurs from Belle Isle, Newfoundland, southward along the Atlantic Coast to Maryland and Virginia

Description: Plants with flowers that appear perfect, but are often functionally unisexual; stigmas $3(-6)$; styles $3(-6)$, distinct, columnar, succulent, ca. $1 \mathrm{~mm}$ long, sometimes persisting in fruit; ovary 1, pyriform, glabrous, 3-4 mm long and equally broad at base, 3-5 bilobed, fused carpels; fruit a tough, leathery, brownish capsule, $5-9 \mathrm{~mm}$ long, (5) 5-10 (12) $\mathrm{mm}$ broad, subglobose to ovoid, unilocular, dehiscing by 3-5 valves; seeds usually 8 or fewer, $4.5 \mathrm{~mm}$ long, ca. $3.5 \mathrm{~mm}$ broad, pyriform or obovate to comma-shaped, often somewhat compressed and distorted, moderately glossy, reddish-brown with minutely muricate surfaces; stamens usually 10 (8-11), 3-4 mm long; anthers golden (brown if non-functional), ovate, ca. $1 \mathrm{~mm}$ broad; filaments fleshy, greenish, thicker toward the base, ca. $3 \mathrm{~mm}$ long, arching upward, with golden nectaries at their bases, where they are inserted on a fleshy disk; perianth of 2 distinct whorls; petals 5 (6), free, spatulate, 3.9-6.2 (7.2) mm long, 2.83.6 (4.5) $\mathrm{mm}$ broad above the claw, creamy to yellowish, somewhat translucent; sepals 5, free, tough, semisucculent 2.9-5.2 (6) $\mathrm{mm}$ long, ca. $3-5 \mathrm{~mm}$ broad, ovate to broadly lanceolate and incurved, with obtuse (to acute), strongly cucullate tips, glabrous, lustrous green with hyaline margins; peduncles stout, 1-3 mm long; flowers borne singly (rarely a pair), mostly in the axils of the upper leaves and branches; leaves opposite, decussate, sessile, succulent, glabrous and glossy, lustrous pale green to jade, (0.4) 0.6-3.5 (4.5) cm long, 0.3-2.7 $(3.5) \mathrm{cm}$ broad, entire, ovate or elliptic or oblong (to broadly lanceolate) with mucronate to apiculate tips, the bases clasping the node, often confluent with those of the leaf opposite; petioles and stipules absent; nodes slightly swollen, with 2 hair-line grooves extending down the internodes from the junctures of the opposite leaf bases; stems succulent, mat-forming, creeping, procumbent to suberect at tips, $10-20(-50) \mathrm{cm}$ tall, with 
lateral branches near the apex, 4-8 $\mathrm{mm}$ broad, yellow-green to creamy, pink at the plant base and brownish when buried under sand or soil, the subterranean, much-branched rhizomes and drift-buried stems ascending at their tips, tough, mostly $2-6 \mathrm{~mm}$ broad with scale-like leaves and adventitious roots at the nodes; root system fibrous $(2 \mathrm{n}=48,66,68,70)$.

Infraspecific Variation: Typical H. peploides ssp. peploides (of arctic-circumboreal distribution) bears its flowers in more or less distinct cymes, whereas ssp. robusta of our range has primarily solitary flowers. Plants of more northerly regions also have relatively flaccid stems, 1-2 mm thick, while the more southern subspecies has turgid, fleshy stems 2-6 mm thick. Another taxon, ssp. major (Hook.) Hultén, occurs north of our range, and is distinguished from the typical subspecies by its smooth seeds and larger, transluscent capsules.

Importance: Honckenya is sometimes planted in sandy gardens and propagated or encouraged along seashores, where it provides a mat-forming ground cover. The leaves and young stems are eaten raw and used in salads, to which they are said to lend a flavor similar to cabbage. In Eurasia the greens are fermented in various ways, used in pickling and made into sour sauces and relishes. In Iceland they are steeped in whey before fermentation; the resulting liquor is strained off for use as a drink or an oily salad dressing.

\section{HOLOSTEUM}

Common Names: Jagged Chickweed

Authority: Linnacus, Species Pl, I, p. 88, 1753

A genus of fewer than 5 species, native to Eurasia.

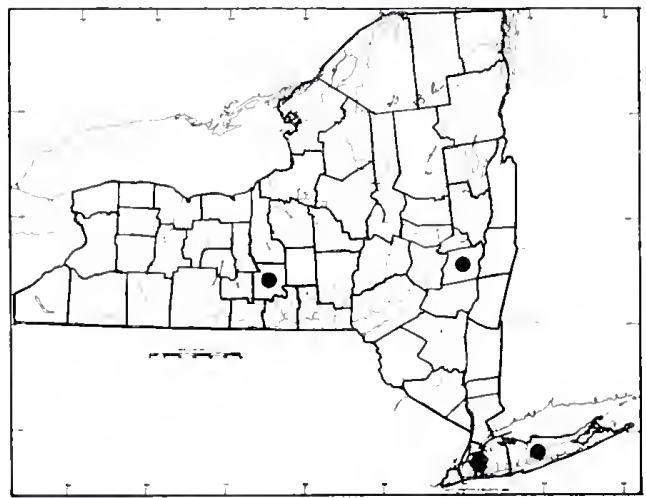

\section{Holosteum umbellatum L.}

Common Names: Jagged Chickweed

Type Description: Linnacus, Species Pl., I., p. 88, 1753

Synonyms: $H$. glutinosum (Bicb.) Fischer \& Meyer, H. umbellatum ssp. glutinosum (Bieb.) Nyman

Origin: Native to Eurasia

Habitats: Sandy soils, escaped on beaches and roadsides, in lawns, fields, waste places

Ilabit: Erect, annual (winter annual) herbs

Flowering: (March) April-May (June)

Fruiting: April-August

General Distribution: A Eurasian adventive in North America, it occurs at scattered locations, mostly along the Coastal Plain from Massachusetts to Georgia, inland to lllinois, Nebraska and Oklahoma, and British Columbia to Oregon; it is probably not as rare in New York State as the distribution map would indicate
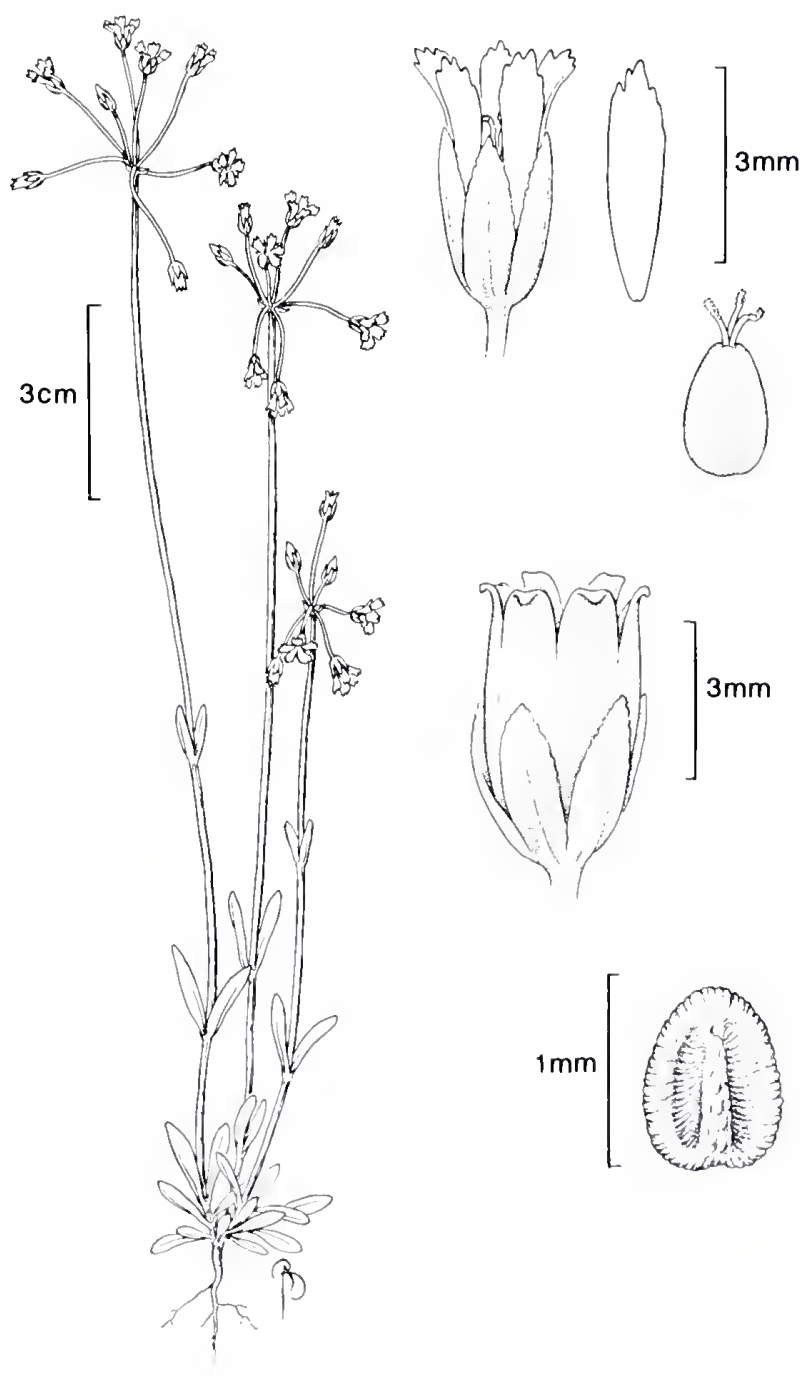
Description: Plants with bisexual flowers; stigmas 3 (4), terminal, minutely papillose, styles 3 (4), linear, 0.4$0.9 \mathrm{~mm}$ long; ovary 1, superior, ovate-elliptic, ca. $1 \mathrm{~mm}$ long; fruit a glossy, tan, striate, thin-walled capsule, 3.6-6.4 mm long, 2.8-3.3 mm broad, cylindric-ovoid strongly exserted from the perianth, especially after dehiscence, the 6 valves with tips reflexed outward; seeds many, tan to reddish-brown, asymmetrical, roughly reniform, 0.4-0.8 mm long and broad, grooved, surfaces both tuberculate and minutely papillose; stamens 3-5 (rarely 8-10); anthers reniform, golden; filaments linear, ca. $1 \mathrm{~mm}$ long; perianth of 2 free whorls; petals 1.6$4.7 \mathrm{~mm}$ long, $1-3 \mathrm{~mm}$ broad, lance-elliptic, white or pale pink, tapering to ragged or cut (entire) tips; sepals 1.4-3.6 mm long, elliptic-ovate, green with hyaline margins and obtuse (to acute) tips, entire, glabrous, persistent and enclosing the lower half of the capsule; pedicels 0.8-2.3 (3) cm long, slender, glabrous, reflexed in fruit; peduncle (1) 3-9 (15) cm long, solitary, terminal, glabrous to densely glandular pubescent and viscid below; inflorescence a simple u mbel of (2) 3-12 (15+) flowers; bracts hyaline, clasping, obtuse, less than $1 \mathrm{~mm}$ long; cauline leaves paired, connate at base, clasping the nodes, 3-20 mm long, 2-8 $\mathrm{mm}$ broad, ovate-elliptic, acute, entire, the margins sometimes ciliate; basal leaves $5-28 \mathrm{~mm}$ long, $2-9$ (13) $\mathrm{mm}$ broad, elliptic-obovate to linear-spatulate, the surfaces glabrous, somewhat glaucous, bases slightly clasping or narrowed to a poorly delineated petiolar zone; stipules absent; stems slender, terete, sometimes grooved, glabrous (below) to glandular-viscid above or throughout, simple to much-branched near the base, erect or ascending, up to 20 (35) $\mathrm{cm}$ long; root system a slender, annual taproot with delicate lateral branching $(2 \mathrm{n}=20)$.

Infraspecific Variation: In Europe, ssp. glutinosum is recognized on the basis of greater overall viscidity and 8-10 stamens rather than 3-5, as in typical plants.

\section{SAGINA}

Common Names: Pearlwort

Authority: Linnaeus, Species Pl. I, p. 128, 1753

A genus of about 15 species distributed mostly in cool-temperate and boreal regions of the Northern Hemisphere. They often inhabit sunny, sandy or rocky sites, and sometimes become weedy, even within their native ranges, following human disturbance.

Description: Plants with bisexual flowers (rarely gynodioecious); stigmas 4-5, papillate along the inner surface of the styles; styles 4-5, alternating with the sepals, recurved at anthesis; ovary 1, 4-5 carpelled, often globose; ovules many (to 130+), campylotropous, on a free central placenta; fruit a 4-5 valved capsule, dehiscing near the apex or splitting to base; seeds many, less than $1 \mathrm{~mm}$ long, globose to triangular, tuberculate, papillate or smooth, sometimes ridged; stamens 4-10, borne in 1-2 whorls of 4 or 5, or the inner whorl missing in some species, the outer whorl with nectaries at the base; anthers minute, ovoid; filaments slender, incurving with age; perianth of two whorls; petals (1) 4-5 (or absent), free, uncleft, often short-clawed and reduced, earlydeciduous or concealed by the calyx in self-pollinating species; sepals 4-5, free, green or with hyaline or colored margins, sometimes forming a splash-cup that aids in seed dispersal during rain; pedicels slender to somewhat thickened; bracts of the inflorescence leafy; cauline leaves opposite, linear or subulate, connate, sheathing at base; basal leaves of perennial species in rosettes; petioles absent; stipules absent; stems decumbent, procumbent or ascending, filiform to thickened and tough at base in perennials; root systems annual taproots or tufted, fibrous, perennial roots, sometimes root-sprouting.

\section{KEY TO SPECIES}

1. Flower parts primarily in 5's (rarely 4's on the same plant); annuals with erect-ascending (or decumbent) often capillary stems and slender taproots, not strongly tufted or spreading by offshoots

1. Perianth parts in 4's (rarely 5 's on the same plant); matted, wiry perennials, spreading by offshoots . .

$\ldots \ldots \ldots \ldots \ldots \ldots \ldots \ldots \ldots \ldots \ldots \ldots \ldots \ldots \ldots \ldots \ldots \ldots \ldots \ldots \ldots \ldots \ldots \ldots \ldots$ 1. S. procumbens

2. Seeds pale brown, triangular with a dorsal groove; capsules longer than broad; pedicels usually

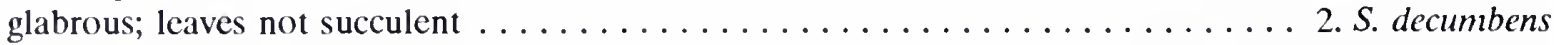

2. Seeds dark brown to almost black, plump, lacking a dorsal groove; capsules globose; pedicels glandular pubescent; leaves succulent .......................... 3. S. japonica 


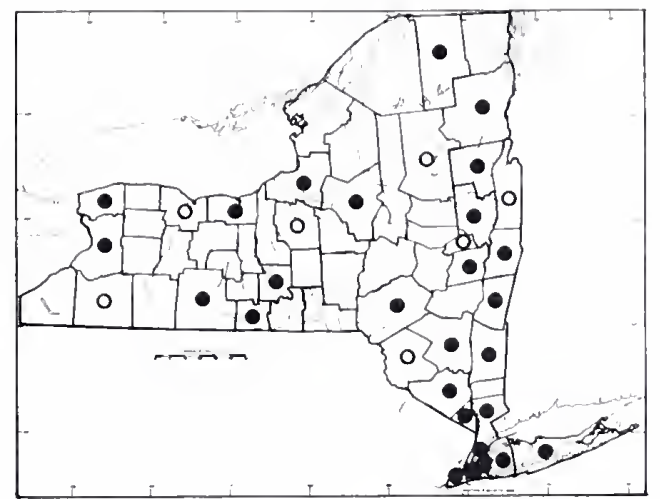

1. Sagina procumbens $\mathrm{L}$.

Common Names: Pearlwort, Perennial or Spreading Pearlwort

Type Description: Linnacus, Species Pl. I, p. 128, 1753

Synonyms: Alsine procumbens (L.) Crantz, $S$. apetala of some NY reports, not Ard., S. corsica Jord., S. muscosa Jord., S. procumbens var. muscosa Jord.

Origin: A native of Eurasia

Ilabitats: River banks, pond and lake shores, rocky, sandy and gravelly areas, gardens, pathways and waste places

ILabit: Procumbent (or ascending), tufted perennials, spreading by offshoots, frequently with well-developed rosettes of leaves

Flowering: May-September

Fruiting: May-October

General Distribution: A native of Eurasia, escaped widely in northeastern North America and the Pacific Northwest, with other scattered occurrences to the Great Lakes States, south to Mexico, Tierra del Fuego and even the Antarctic. Some floras have treated it as a native North American species, but this is very doubtful, considering its history of aggressive, weedy spread from port towns worldwide

Description: Plants with bisexual flowers; stigmas 4 (5), papillose receptive areas on the upper styles; styles 4 (5), minute, linear, persisting until dehiscence; ovary 1, superior, ovoid, ca. $1 \mathrm{~mm}$ long; fruit a 4-valved capsule, tan, 1.6-3.0 mm long, 1.2-1.7 (2.0) $\mathrm{mm}$ broad, dehiscing explosively, the valve tips extended, tonguelike, the spent, exserted capsule up to $3.3 \mathrm{~mm}$ long; seeds many, brown, minutely tuberculate, $0.2-0.4 \mathrm{~mm}$ broad, plumply triangular; stamens 4 (8), free; anthers minute, yellowish; filaments pale, slender, ca. $1.3 \mathrm{~mm}$ long, incurved at anthesis; perianth of 2 free whorls; petals 4 (rarely some flowers on the same plant with 5), ovate-elliptic, 0.7-1.5 mm long and broad, white, caducous; sepals 4 (rarely 5) greenish with hyaline margins, 1.1-2.5 mm long and broad, cucullate, with obtuse tips, persisting and divergent after capsule dehiscence, sometimes minutely glandular at base; pedicels slender, glabrous, often recurved in fruit; inflorescence reduced: flowers solitary, terminal, or 2, (with 1 at the penultimate node); bracts leaf-like, linear; cauline leaves linear, reduced upward on the stem, $2-6 \mathrm{~mm}$ long, borne in pairs with hyaline connate bases and apiculate tips; basal leaves similar to cauline ones, but larger, $6-16 \mathrm{~mm}$ long, often tufted in distinct rosettes; petioles absent; stipules absent; stems procumbent (rarely ascending) glabrous, greenish, $1-8 \mathrm{~cm}$ long, spreading by offshoots; root system fibrous, perennial, sometimes root-sprouting $(2 n=22)$.

Infraspecific Variation: Depauperate plants from severe, northern shorelines have been called var. compacta Lange, but their condition is apparently environmentally induced and clinal, with intermediate individuals bridging a transition to more typical plants nearby. 
Importance: These plants are sometimes grown as a ground cover in sandy areas, but this practice is not encouraged, due to the weedy nature of the species.

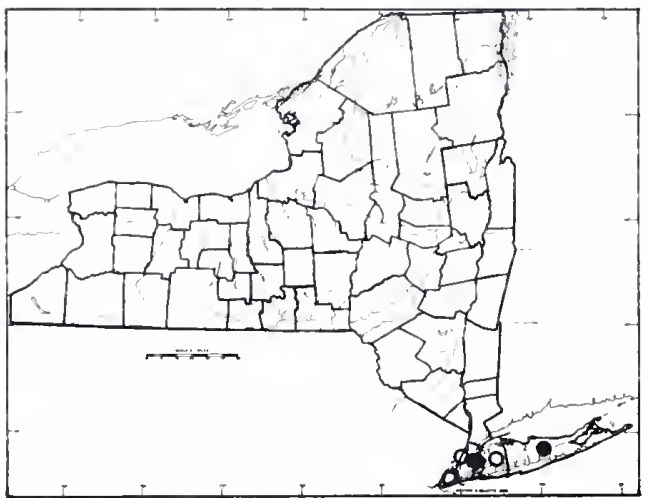

2. Sagina decumbens (Ell.) Torr. \& Gray Common Names: Pearlwort, Annual Pearlwort Type Description: Elliott, Sketch. Bot. S.C. \& Ga. I., p. 523, 1821

Synonyms: Sagina apetala of some NY reports, not Ard., S. subulata var. smithii Gray, S. decumbens var. smithii (Gray) Watson, Spergula decumbens Ell.

Origin: A native of North America

Habitats: Sandy soils in partial to full sunlight, pine-scrub, open fields and meadows; a native weed southward on roadsides, lawns, sidewalks and in waste places

Ilabit: Erect-ascending to decumbent, delicate annuals with slender taproots

Flowering: (April) May-June

Fruiting: May-September

General Distribution: Mainly distributed from New England to Kansas and southward to Texas and Florida; widely disjunct to New Brunswick, Alberta, Saskatchewan and Arizona

Rarity Status: These plants are near the northern edge of their contiguous range in New York State, where they were rediscovered on Long Island in 1991. The Natural Heritage rank is G5 (globally secure) S1 (5 extant sites or fewer), and E (endangered) under State law.

Description: Plants with bisexual flowers; stigmas (4) 5, papillose receptive areas on the upper style surfaces; styles (4) 5, minute, linear, persisting until dehiscence; ovary 1, superior, ovoid, ca. $1 \mathrm{~mm}$ long; fruit a (4-) 5valved capsule, tan, 1.5-3.1 mm long, 1.0-1.5 (2.1) mm broad, dehiscing explosively, the valve tips then exserted from the perianth, appearing tongue-like, making the spent capsule up to $3.7 \mathrm{~mm}$ long; seeds 10-many, pale tan, with a dorsal groove, weakly tuberculate to smooth, 0.2-0.7 (1.1) $\mathrm{mm}$ broad, plumply triangular; stamens 6-10, free; anthers minute; yellowish; filaments pale, slender, ca. $1.3 \mathrm{~mm}$ long, incurving at an thesis; perianth of 2 free whorls; petals 5 (rarely 4 or absent) ovate-elliptic, 1.2-2.5 mm long and broad, white; sepals 5 (rarely 4) greenish with hyaline margins, $0.8-2.2 \mathrm{~mm}$ long and broad, cucullate, with purplish, obtuse tips, persisting and appressed after capsule dehiscence, sometimes minutely glandular at base; pedicels slender, glabrous or minutely glandular; flowers borne singly, terminally or in upper leaf (bract) axils, the diffuse inflorescence vaguely cymose; bracts and leaves equivalent in the inflorescence; cauline leaves linear, 2-13 (22) $\mathrm{mm} l o n g$, borne in pairs, with hyaline connate bases and apiculate tips, greenish, sometimes purple-tinged near the base; basal leaves similar to cauline ones, early-withering, not in distinct rosettes; petioles and stipules absent; stems 
capillary, glabrous or minutely glandular, greenish to purple-tinged, erect-ascending or decumbent, 2-12 (16) $\mathrm{cm}$ long; root system a delicate, thread-like taproot $\left(2 \mathrm{n}_{\mathrm{i}}=36\right)$.

Infraspecific Variation: Pubescence is quite variable in this species, especially regarding glandular hairs whose presence or absence varies within populations and even individuals. The tuberculate seed character is also variable within populations, being obscured in some individuals. Slender plants, that are nearly apetalous, often 4-merous and set few seeds, have been called var. smithii (Gray) Watson, but Crow (1978) treats such plants as extreme manifestations of a broad range of variability and recommends that no formal taxonomic status be assigned to them. Western North American populations, designated ssp. occidentalis, are distinguished by more orbicular sepals, globose capsules and seeds that lack both reticulate ridges and tuberculate surfaces.

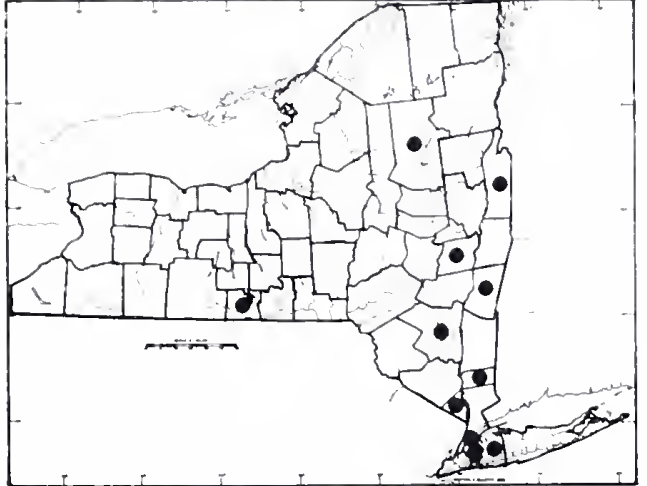

3. Sagina japonica (Sw.) Ohwi

Common Names: Pearlwort, Japanese Pearlwort

Type Description: Swartz, Gesel. Nat. Freunde (Berlin), Neue Schrift, vol. 3, p. 164, 1801

Synonyms: S. echinosperma Hayata, S. sinensis Hance, S. taquetii Lév.

Origin: A native of eastern Asia

llabitats: Sandy, gravelly places: urban streets, driveways and building foundations; shores of the estuarine Hudson River

Ilabit: An ascending (rarely decumbent), semisucculent annuals from taproots

Flowering: June-August

Fruiting: June-October

General Distribution: An Asiatic weed, overlooked on the east coast of North America until the 1990s: Massachusetts, Connecticut, New York, Ontario, British Columbia and Oregon

Description: Plants with bisexual flowers; stigmas $4-5$, minutely pubescent; styles $4-5$, ca. $0.3 \mathrm{~mm}$ long, persistent until dehiscence; ovary globose, ca.

$1 \mathrm{~mm}$ broad; fruit a globose, 5 -valved capsule $1.6-2.2 \mathrm{~mm}$ in diameter, valves dehiscing only about $1 / 4$ their lengths, apparently not explosively, walls somewhat translucent showing outlines of the dark seeds within; seeds many, 0.2-0.3 mm long, plump, dark brown to ebony, lacking a dorsal groove, the surfaces moderately to densely and prominently tuberculate; stamens 5, about equaling the perianth; anthers minute, globose, golden; filaments pale, slender, 0.9-1.4 mm long; perianth of two distinct, free whorls, both often persistent in fruit; petals white, ovate with obtuse tips, 1.1-1.6 $\mathrm{mm}$ long, 0.7-1.0 $\mathrm{mm}$ broad; sepals broadly ovate-orbicular with acute to obtuse tips, $0.9-1.8 \mathrm{~mm}$ long, $0.7-1.3 \mathrm{~mm}$ broad, green with hyaline margins, glandular pubescent on the adaxial surfaces, especially below; pedicels slender, $0.3-2.7 \mathrm{~cm}$ long, glandular pubescent over the upper half to $2 / 3$ of their length; bracts leaf-like, narrowly lanceolate; inflorescence reduced to a single terminal flower, or more often 2 flowers, one terminal and the other at the penultimate node; cauline leaves paired, 
linear, glabrous, $0.5-1.8 \mathrm{~cm}$ long, ca. $0.6 \mathrm{~mm}$ broad, somewhat succulent, the tips apiculate, bases conspicuously connate, sheathing, hyaline; basal leaves similar, persistent, sometimes congested, but not in tufted rosettes; petioles absent; stipules absent; stems capillary, ascending or procumbent, glabrous to glandular-puberulent; root system a slender or somewhat thickened, annual taproot with copious, fibrous, lateral branches $(2 \mathrm{n}=$ $42,44,46,64)$.

Infraspecific Variation: Measurements of flower parts, capsules and seeds from plants occurring in the eastern United States run somewhat smaller than those reported by Crow (1978) for plants escaping on the West Coast. In addition, most of the East Coast plants have seed walls that are not as densely or prominently tuberculate as those described from the west except for a couple of individuals. Whether these plants have been introduced more than once in Eastern North America is not clear.

Importance: A weed that has turn out to be far more common than expected in the Hudson Estuary; it was first collected in the New York State in the 1940s, but not correctly identified until 1990.

\section{MINUARTIA}

\section{Common Names: Sandwort, Arenaria}

Authority: Linnaeus, Species, Pl. I, p. 89, 1753

A genus of 100 or more species, native to Eurasia. They have often been included in the genus Arenaria in North American treatments, but their fewer, uncleft capsule valves, xeromorphic leaf structure and habit seem sufficient to warrant the recognition of a separate genus, as has been done in Europe for some time.

Description: Plants with bisexual flowers; stigmas as many as the styles, often 3; styles (2-) 3 (-5), free; ovary 1 , bearing few to many ovules; fruit a (2-) $3(-5)$ valved capsule; seeds numerous, small, indented or cleft, some tuberculate or fimbriate; embryo arched around a starchy perisperm; stamens (6-8) 10; filaments slender; anthers globose; perianth of 2 distinct, free whorls; petals 5 , not deeply cleft; sepals 5, greenish, 1-5-veined; pedicels and peduncles slender; bracts often paired, sometimes unequal; leaves linear to linear-lanceolate, setaceous or subulate, paired and connate at base; petioles obscure; stipules lacking; stems often wiry, branched throughout or only near the base; root systems annual or perennial.

\section{KEY TO SPECIES}

1. Sepals with acute or acuminate tips, strongly ribbed throughout their lengths $\ldots \ldots$. . 1. M. michauxii

1. Sepals with obtuse to rounded tips; not strongly ribbed over their entire lengths (though sometimes ribbed

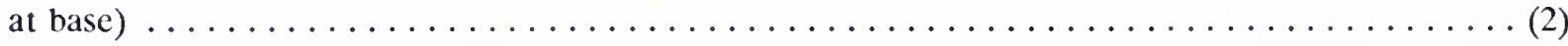

2. Leaves stiff, squarrose, broader toward the base, borne on tough, semi-woody branches from a thick caudex and rootstock; capsule strongly exserted from the calyx; petals not notched or indented at the

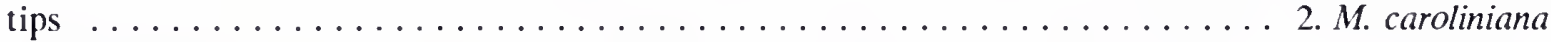

2. Leaves delicate, linear, not strongly broadened at the base, borne on delicate stems from weak to capillary taproots; capsule not strongly exserted; petals usually retuse . . . . . . . . . . . . (3)

3. Flowering stems weakly ascending, usually less than $5 \mathrm{~cm}$ tall; vegetative stem bases matted, profusely branched and densely cespitose; pedicels mostly $1.5 \mathrm{~cm}$ or less $\ldots \ldots \ldots \ldots \ldots$. . groenlandica

3. Flowering stems erect or strongly ascending, $5-20(28) \mathrm{cm}$ tall; vegetative bases ranging from single stems to weakly cespitose, but not profusely branched and matted; pedicels ranging up to $3 \mathrm{~cm}$, sometimes longer $\ldots \ldots \ldots \ldots \ldots \ldots \ldots \ldots \ldots \ldots \ldots \ldots \ldots \ldots \ldots \ldots \ldots \ldots \ldots \ldots \ldots \ldots \ldots \ldots$ 


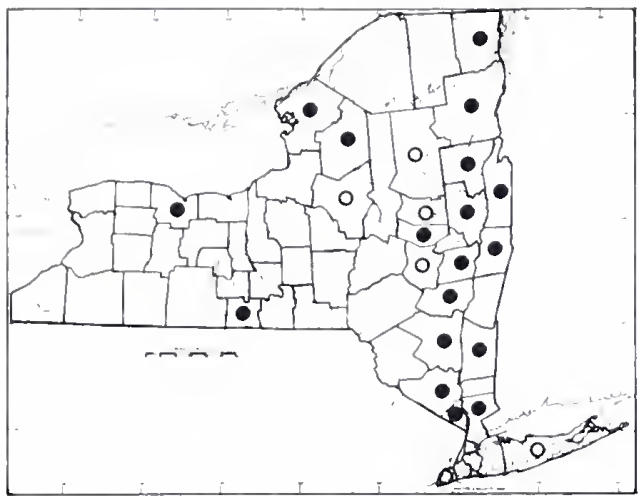

1. Minuartia michauxii (Fenzl) Farw.

Common Name: Rock Sandwort

Type Description: Fenzl, Verbr. Alsin., p. 18, 1833

Synonyms: Alsine michauxii Fenzl, Arenaria macra Nels. \& Macbr., A. michauxii (Fenzl) Hook.f., A. stricta Michx., Sabulina stricta (Michx.) Small Origin: A native of eastern North America

Habitats: Rocky and gravelly places, limestone flatrock, less frequently on sandy soils and granitic ledges

IIabit: Erect-ascending, wiry, annual or perennial herbs, sometimes matted at base, often tufted with short-shoots in the leaf axils

Flowering: May-July

Fruiting: June-September

General Distribution: New Hampshire to western

Ontario (sensu lato to the Yukon) south to

Texas and Arkansas

Description: Plants with bisexual flowers; stigmas 3; styles 3, filiform, free to base, translucent, 1.4-2.1 $\mathrm{mm}$ long; ovary 1, superior, ovoid; fruit an ovoid capsule, $4-5 \mathrm{~mm}$ long, ca. 2.5 broad, included or only slightly exserted from the persistent calyx, shiny, tan, dehiscing by 3 entire valves to below the middle; seeds many, 0.8-1.2 (1.5) mm long, somewhat compressed, reniform, the dark brown surface rugose; stamens 8-10; anthers ovoid, golden, minute; filaments slender, pale, $3-4$ (5) mm long;

perianth of 2 distinct, free whorls; petals white, ovoid to obovate with entire margins, $5-8 \mathrm{~mm}$ long, $3-5 \mathrm{~mm}$ broad; sepals $3.8-4.9 \mathrm{~mm}$ long, $2-3 \mathrm{~mm}$ broad, ovate to broadly lanceolate with acute to acuminate tips, strongly 3 (4) ribbed on the abaxial surface, the margins enire, borders somewhat membranaceous; pedicels 0.6-2.0 (3.9) $\mathrm{cm}$ long, slender, glabrous; inflorescences cymose-paniculate, both terminal and lateral in the upper axils; bracts often paired, narrowly deltoid, acuminate, with a prominent midrib and hyaline margins; leaves paired and borne in axillary tufts on short-shoots, linear-setiform, 0.5-1.5 (2.9) cm long, ca. $0.2 \mathrm{~mm}$ wide, spreading to squarrose, ribbed and grooved, glabrous and glossy green, the bases expanded to clasp the node as a shallow, hyaline cup; petioles absent; stipules absent; stems wiry, branching at the base, producing tufted short-shoots in the upper axils, glabrous, olive-green to reddish-tan, leafy with nodes crowded toward the base, flowering stems diffuse, erect and spreading, up to $30 \mathrm{~cm}$ tall; root system sometimes annual, but often persisting to become a branched, semi-woody, perennial slock $(2 \mathrm{n}=30)$.

Infraspecific Variation: A member of a variable complex, with taxa sometimes treated conspecifically under M. michauxii and sometimes split. Minuartia dawsonensis (Britt.) House, ranging north and west of our range, is segregated on the basis of shorter petals, marcescent basal shoots and a lack of tufted short-shoots on the upper stems. To the southwest, M. michauxii var. texana (Robbins.) Mattf. is recognized by its revolute, lanceolate sepals and stiff, densely-branched flowering stems. 


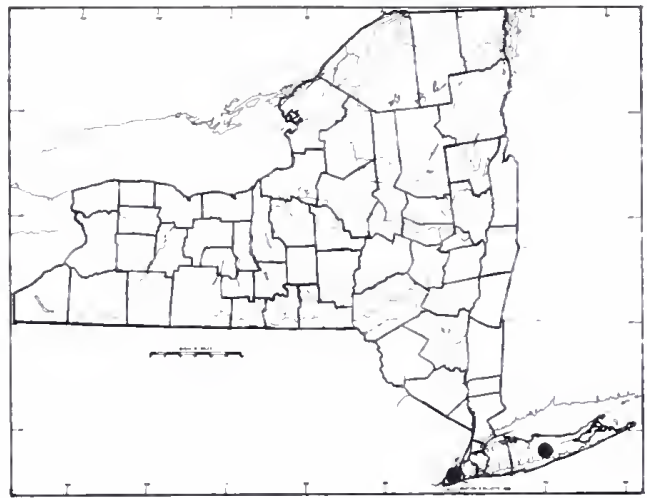

2. Minuartia caroliniana (Walt.) Mattf.

Common Names: Pine-barren Sandwort, Longroot, Squarrose Sandwort

Type Description: Walter, Fl. Car., p. 141, 1788

Synonyms: Arenaria caroliniana Walt., $A$. squarrosa

Michx., Sabulina caroliniana (Walt.) Small

Origin: A native of coastal eastern North America

Ilabitats: Sandy, open, coastal areas, beaches, dunes, thickets and oak-pine scrub

IIabit: Tufted to cespitose perennials from stout rootstocks; flowering stems strongly ascending

Flowering: (May) June-September

Fruiting: June-November

General Distribution: Formerly southern Rhode Island; currently eastern Long Island, New York, scattered along the coast to New Jersey, Virginia, the Carolinas, Georgia and North Florida

Rarity Status: This species is protected under New York State law, listed R (rare), with a New York Natural Heritage rating of G5 S3.

Description: Plants with bisexual flowers; stigmas 3-4, minutely capitate; styles 3-4, filiform, free to base, 0.8$2.8 \mathrm{~mm}$ long; ovary 1, superior, ovoid; fruit an ovoid capsule, variable in size at dehiscence, 5.2-9.8 $\mathrm{mm}$ long, 2-5 mm broad, exserted from the persistent calyx, shiny, tan, dehiscing by 3-4 entire valves to below the middle; seeds many, 0.7-1.0 mm long, somewhat compressed, surface brown, rugose (seeds often abortive in ours); stamens 6-10; anthers ovoid, golden, minute; filaments slender, reddish, 4-5 mm long; perianth of 2 distinct, free whorls; petals white, obovate with entire margins, 5-9 mm long, 4-6 mm broad; sepals 3.3-5.3 mm long, 1-3 $\mathrm{mm}$ broad, ovate with rounded tips, not strongly ribbed, the margins entire, green, the borders somewhat membranaceous; pedicels $0.5-2.4 \mathrm{~cm}$ long, glandular-hispidulous; inflorescences mostly terminal and subterminal cymes; bracts often paired, lance-acuminate with hyaline margins; leaves paired and crowded near the stem base on short vegetative shoots, linear to lance-subulate, $0.3-1.1 \mathrm{~cm}$ long, 0.3-0.9 $\mathrm{mm}$ broad, sometimes expanded to over $1 \mathrm{~mm}$ at the clasping base, squarrose, often with a prominent midrib, sometimes grooved, glabrous and glossy green; petioles absent; stipules absent; stems densely matted at base, moderately creeping, producing erect, stiff vegetative shoots, glabrous, green to brown, erect flowering stems $5-17 \mathrm{~cm}$ tall, with few nodes; root system a stout, erect, somewhat woody, perennial stock.

Importance: These plants help to stabilize sandy soils and dunes in the few places where they occur. 


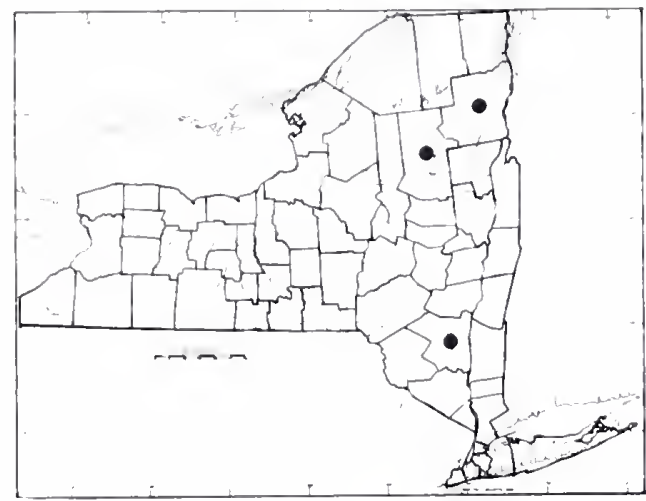

3. Minuartia groenlandica (Retz.) Ostenf.

Common Names: Mountain Sandwort, Mountain Starwort, Mountain Daisy

Type Description: Retzius, Fl. Scand. ed. 2, p. 107, 1795

Synonyms: Arenaria groenlandica (Retz.) Spreng., Sabulina groenlandica (Retz.) Small, Stellaria groenlandica Retz.

Origin: A native of arctic and boreal North America (montane Brazil)

Habitats: Rocky, gravelly, open places in montane and coastal, arctic and boreal climates: alpine summits, ledges and other acidic, exposed sites in shallow soil and full sunlight

Habit: Plants with densely-branched mat-forming stems, rosettes of needle-leaves and short, slender flowering branches; winter annuals

Flowering: (May) June-August

Fruiting: June-September

General Distribution: Greenland to Nova Scotia, northern Quebec and the Gaspe Peninsula, to Maine, Vermont and New York, with outliers south Virginia and the Carolinas; incorrectly reported from Illinois; there is also a confirmed report from montane, southeastern Brazil

Description: Plants with bisexual flowers; stigmas (2) 3, minutely capitate; styles (2) 3, free slender, hyaline, ca. $1.5 \mathrm{~mm}$ long; ovary 1, fusiform, pale green; fruit a capsule, $4.0-5.4 \mathrm{~mm}$ long, 1.6-2.3 mm broad, fusiform, 3 -valved, dehiscent to near the base, tan, smooth, a remnant of the style base persistent and slightly notched at the apex; seeds many, rich reddish-brown, minutely rugulose, 0.6-0.9 $\mathrm{mm}$ broad, comma-shaped, indented on both sides and between 2 dorsal ridges; stamens 8 (10); anthers globose, pale, minute; filaments threadlike, hyaline, 3.8-4.7 mm long, somewhat coherent at the bases; perianth of 2 series; petals 5, alternating with the sepals, 5.7-8.4 (10) $\mathrm{mm}$ long, 2.8-3.9 $\mathrm{mm}$ at broadest point, spatulate-retuse, the V-shaped notch ca. 0.5 $\mathrm{mm}$ deep, petals white, with veins that are somewhat greenish; sepals pale green with hyaline margins, 2.6-3.8 $\mathrm{mm}$ long, $1.0-1.5 \mathrm{~mm}$ broad, ovate to ovate-lanceolate with acute to obtuse tips, the bases yellow-green, scarcely connate, but fusing with the shallow cup of the expanded receptacle; pedicels $(0.4) 0.6-1.6(2.2) \mathrm{cm}$ long, wiry, glabrous, pale green, often browning in fruit; inflorescence a cyme-like panicle of laterally and terminally borne single flowers, usually numbering 4-7 per flowering stem; inflorescence bracts paired (equal in size, or one may be minute), linear, $0.4-3.5 \mathrm{~mm}$ long, subterete, flat or grooved, usually somewhat smaller than cauline leaves, usually distinguishable only by the associated axillary pedicels; cauline leaves subterete, linear, (1) 2-8 mm long, glabrous, green, browning early, sometimes with a minute, lateral shoot in the axil of one leaf of the pair; basal leaves 3-15 (23) mm long, linear to linear-oblanceolate, opposite, crowded into dense mats at the bases of flowering stems and on short, lateral vegetative shoots; petioles absent, the leaf bases flattened and clasping; fruiting stems erect, $1-8(15) \mathrm{cm}$ tall, slender, glabrous, green to red-brown, with 
2-3 vegetative internodes of $0.8-1.5 \mathrm{~cm}$ each above the basal rosette before branching to form the inflorescence; vegetative stems copious, less than $1 \mathrm{~cm}$ tall, with very short internodes, shiny, pale brown with crowded needle-like leaves; root system fibrous, densely spreading from a slender taproot $(2 n=20)$.

Infraspecific Variation: A number of similar taxa have been segregated from this species, particularly south of its contiguous range in eastern North America where they are often found in isolated, specialized habitats. The following species, M. glabra (Michx.) Mattf., is one of those taxa (sce discussion below).

Importance: This species is one of the early colonizers and soil builders on rocky ledges and alpine summits, along with mosses lichens and Potentilla tridentata Soland. ex Ait.

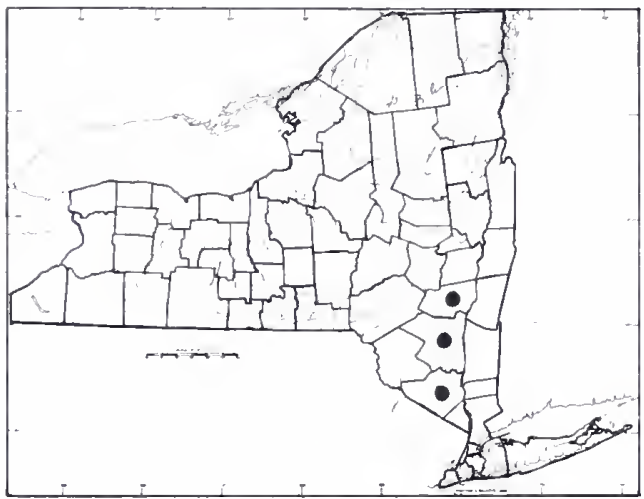

4. Minuartia glabra (Michx.) Mattf.

Common Names: Appalachian Sandwort, Mountain Sandwort, Mountain Starwort, Mountain Daisy

Type Description: Michaux, Fl. Bor. Amer. I, p. 274,1803

Synonyms: Alsinopsis glabra (Michx.) Small, Arenaria glabra Michx., A. groenlandica var. glabra (Michx.) Fern., M. groenlandica ssp. glabra (Michx.) Löve \& Löve, Sabulina glabra (Michx.) Small

Origin: A native of the Appalachian Shield of North America

IIabitats: Acid soils of ledges or in shallow, vernally moist depressions over sandstone conglomcrate, usually in full sunlight; cliffs in severe, lichen and moss-dominated habitats where there is little competition

IIabit: Winter annuals with tufted rosettes and slender, erect, flowering stems

Flowering: (May) June-September

Fruiting: July-October

General Distribution: Sporadic in montane Maine, New Hampshire, New York and northeastern Pennsylvania Rarity Status: This species is protected under New York State law considered T (threatened), with a Natural Heritage Program rank of G4G5Q S2.

Description: Plants with bisexual flowers; stigmas (2-) 3, minutely capitate; styles (2-) 3, free slender, hyaline, ca. $1.5 \mathrm{~mm}$ long; ovary 1 , fusiform, pale green, $1.2-1.8 \mathrm{~mm}$ long, $0.8-1.1 \mathrm{~mm}$ broad; fruit $4.2-5.1 \mathrm{~mm}$ long, 1.9 $2.2 \mathrm{~mm}$ broad, fusiform, 3-valved, tan, smooth, a remnant of the style base persistent and slightly notched at the apex; seeds many, rich reddish-brown, minutely rugulose, $0.6-0.8 \mathrm{~mm}$ broad, comma-shaped, indented on the sides and between the 2 dorsal ridges; stamens $8(-10)$; anthers globose, pale to bright yellow, minute; filaments thread-like, hyaline, 3.4-4.1 mm long, cohering slightly at the disc-like receptacle; perianth of 2 series; petals 5, alternating with the sepals, 5.0-6.4 (-8) $\mathrm{mm}$ long, 2.2-3.1 $\mathrm{mm}$ at broadest point, spatulateretuse, the V-shaped notch ca. $0.5 \mathrm{~mm}$ deep, petals white, with 4.6 large, often greenish veins; sepals pale 
green with hyaline margins, 2.9-3.4 mm long, ca. $1.5 \mathrm{~mm}$ broad, ovate with acute to obtuse tips, the bases yellow green, scarcely connate, but fusing with the shallow cup of the expanded receptacle; pedicels (0.4) 1.0$2.4 \mathrm{~cm}$ long, very slender and wiry, glabrous, pale green, often browning in fruit; inflorescence a cyme-like panicle of, solitary flowers, usually numbering 9-12 (16) per plant; inflorescence bracts paired (equal in size, or one may be minute), linear, 1-6 mm long, subterete, flat or grooved along the upper margin, usually somewhat smaller than cauline leaves, or only distinguishable by the associated axillary pedicels; cauline leaves subterete, linear, sessile, (1) 4-12 (15) mm long, glabrous, green, browning early, often with a minute, green, lateral shoot in the axil of one leaf of the pair; basal leaves 4-22 (26) $\mathrm{mm}$ long, opposite, crowded into dense rosettes at the bases of flowering stems and also on short, lateral vegetative shoots; petioles absent, the leaf bases flattened and slightly clasping; fruiting stems erect, 9-14 (22) cm tall, slender, glabrous, green to redbrown, with 2-3 vegetative internodes of $1-2 \mathrm{~cm}$ each above a basal rosette, branching above to form the inflorescence; vegetative stems few, mostly less than $1 \mathrm{~cm}$ tall, branching upward from a larger, arched main stem with a shiny, pale brown surface, each short shoot crowned by a dense rosette of needle-like leaves; root system fibrous, densely spreading.

Infraspecific Variation and Hybridization: Minuartia glabra is frequently listed as a variety of M. groenlandica, but it may be distinguished vegetatively by its erect to spreading, rather than mat-forming, habit. The taller flowering stems bear 8-15 flowers that are consistently smaller, on the average, than those of mat-forming $M$. groenlandica, though some overlap in size does occur. A closely related species, $M$. uniflora (Walt.) Mattf. [M. alabamensis McCormick et al.], is largely restricted to granitic outcrops in the southern Appalachians. Minuartia glabra has been reported to occur sympatrically with $M$. uniflora in areas where populations of that species are apparently obligate self-pollinators, and hybrids between the two are not known (Wyatt, 1990). Importance: This species is one of the early colonizers and soil builders in bare, rocky habitats, establishing soon after lichens and mosses gain a foothold.

\section{CERASTIUM}

\section{Common Names: Mouse-ear Chickweed}

Authority: Linnaeus, Species Pl. I, p 437, 1753

A genus of 100 species or more, distributed widely, mostly in the North Temperate Zone. There are more species in Europe (ca. 60) than in North America, and the genus is also well-represented in Asia. A number of Cerastium species, both native and introduced, are weeds of lawns, gardens and streets. The field chickweed (C. ariense L.) and two species called snow-in-summer may have showy flowers, and are cultivated in gardens, from which they sometimes escape.

Description: Plants with bisexual flowers; stigmas (3-4) 5; styles (3-4) 5; ovary 1, superior, unilocular; ovules many, borne on a free central placenta; fruit a membranous capsule, often contorted toward the apex, dehiscing by (6-8) 10 hygroscopic teeth surrounding an apical or subapical aperture; seeds numerous, usually grooved, papillate or rugulose; embryo curved; stamens 5-10, free; filaments slender; anthers globose to oval; perianth of 1 or 2 free whorls of 5; petals 5 or fewer (sometimes lacking), usually white, emarginate to bifid (rarely entire); sepals 5 (rarely 4), free, persistent; pedicels usually slender; bracts herbaceous or scarious; inflorescences often cymose (or flowers solitary in leaf axils); leaves opposite, usually entire, clasping at base, ovate to linear; petioles absent or obscure; stipules absent; stems cespitose, usually pubescent, creeping, ascending or erect; root systems annual or perennial. 


\section{KEY TO SPECIES}

1. Surfaces of the sepals, leaves and stems matted with a dense, woolly tomentum, giving the plant a gray to silvery appearance throughout; flowers often showy, up to $2.5 \mathrm{~cm}$ broad . . . . . . . . . . (2)

1. Surfaces of the sepals variously pubescent, sometimes densely so (to glabrescent), but not matted with a dense, silver wool or tomentum; plants appearing pale to dark green; flowers showy or not . . . . (3)

2. Terminal internode (subtending the inflorescence) about twice the length of the one below it, commonly 8-12 cm long; leaves broadly lanceolate to lance-elliptic, not revolute; capsule teeth flat, not revolute or spreading $\ldots \ldots \ldots \ldots \ldots \ldots \ldots \ldots \ldots \ldots \ldots \ldots \ldots \ldots \ldots \ldots \ldots \ldots$ biebersteinii $]^{1}$

2. Terminal internode not significantly longer than the one just below it, usually less than $6 \mathrm{~cm}$ long; leaves linear to narrowly lanceolate, at least slightly revolute; capsule teeth revolute, often spreading $\ldots \ldots \ldots \ldots \ldots \ldots \ldots \ldots \ldots \ldots \ldots \ldots \ldots \ldots \ldots \ldots \ldots \ldots \ldots \ldots \ldots$. tomentosum

3. Uppermost inflorescence bracts (those directly subtending the pedicels of the flowers) with scarious margins, at least toward the apex, often resembling the sepals $\ldots \ldots \ldots \ldots \ldots \ldots \ldots \ldots \ldots \ldots$ (5)

3. Uppermost inflorescence bracts herbaceous, leaf-like, the tips and margins not scarious ........ (4)

4. Cauline leaves and bracts broadly elliptic to obovate, mostly less than 4 times as long as broad; calyx with glandular-hispid pubescence, up to $1 \mathrm{~mm}$ long; inflorescences densely congested, especially when in flower, but often glomerate, even in fruit $\ldots \ldots \ldots \ldots \ldots \ldots \ldots \ldots \ldots$. glomeratum

4. Cauline leaves lanceolate, narrowly elliptic to oblanceolate; bracts lanceolate; leaves and bracts mostly 5-8 times as long as broad (or more); calyx pubescence short glandular-villous; inflorescences congested only when young, the axes elongate at maturity .................. nutans

5. Petals showy, exceeding the sepals by $1-2$ lengths; leaves mostly linear-lanceolate ...... 4. C. ariense 5. Petals not showy, shorter, equal or very slightly longer than the sepals; leaves mostly oval to ellipticlanceolate . . . . . . . . . . . . . . . . . . . . . . . . . . . (6)

6. Fruiting calyces mostly 3-4 mm long; stamens usually 5; the best developed cauline leaves rarely reaching $1 \mathrm{~cm}$ in length; annual plants with taproots ............ 5. C. semidecandrum

6. Fruiting calyces mostly 5-6 mm long; stamens usually 10 ; well developed cauline leaves often $1-2 \mathrm{~cm}$ or longer; perennials with rhizomes and basal shoots $\ldots \ldots \ldots \ldots \ldots \ldots \ldots \ldots$ fontanum

${ }^{1}$ Cerastium biebersteinii $\mathrm{DC}$. is a rare garden escape, closely related to $C$. tomentosum L., that is confused with it in both the nursery trade and northeastern floras. At NYS, there is a specimen collected from a garden on Long Island, not far from where an escaped population was found a few years later. The species is planted as a garden novelty and perennial ground-cover in sandy and rocky, open places. Its low-growing, silvery foliage adds a pleasant touch to garden borders. 


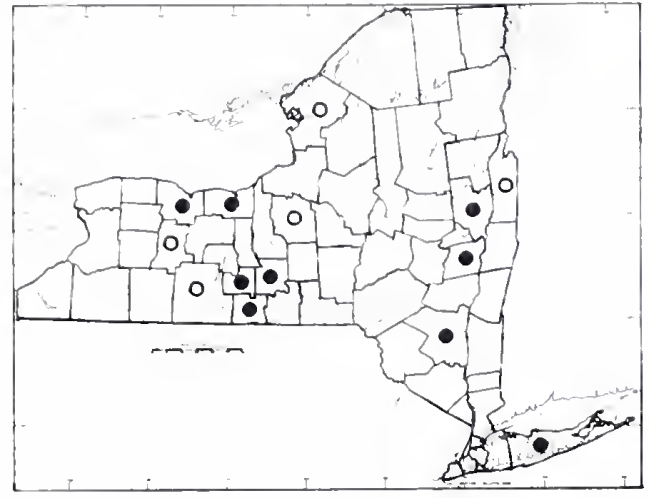

1. Cerastium tomentosum $\mathrm{L}$.

Conmon Names: Snow-in-summer

Type Description: Linnacus, Species Pl. I, p. 440, 1753

Synonym: $C$. columnae Tenore

Origin: Native to Mediterranean Europe

Ilabitats: Roadsides, sandy gullies and rocky shores as a garden escape

Ilabit: Spreading, matted, perennial herbs with ascending, flowering stem-tips

Flowering: May-July

Fruiting: July-August

General Distribution: A native of Italy; escaping cultivation in relatively frequently in Eurasia, but infrequent as a garden escape in temperate North America

Description: Plants with bisexual flowers; stigmas 5; styles 5, filamentous, $3-4 \mathrm{~mm}$ long; ovary 1 , free, ovoid; fruit a cylindric capsule, glossy, greenish-tan, $9-10 \mathrm{~mm}$ long, ca. $3 \mathrm{~mm}$ broad, not strongly contorted, dehiscing by 10 unequal, erect to spreading teeth with revolute margins; seeds few, comma-shaped, $2.3-2.7 \mathrm{~mm}$ long, 1.5-1.8 mm broad, red-brown, strongly tuberculate, the lateral tuberculae elongate; stamens 6-10, free; anthers narrow, ca. $1 \mathrm{~mm}$ long; filaments linear, $4-6 \mathrm{~mm}$ long; perianth of 2 free whorls of 5; petals white, $8-14 \mathrm{~mm}$ long, up to $7 \mathrm{~mm}$ broad, entire, notched or bilobed up to $1 / 3$ their length, the petal (lobe) tips entire or minutely erose; sepals ovate, $5-8 \mathrm{~mm}$ long $3-5 \mathrm{~mm}$ broad with obtuse tips and broad hyaline margins, the abaxial surfaces otherwise densely matted with a woolly tomentum; pedicels $4-20 \mathrm{~mm}$ long, usually densely woolly; inflorescences open, few-flowered terminal cymes; bracts paired, much like the sepals, $3-8 \mathrm{~mm}$ long, 2-4 mm broad, ovate, obtuse, with a heavy tomentum and hyaline margins; leaves linear to lanceolate or oblanceolate with acute to obtuse tips, $1-3$ (4) $\mathrm{cm}$ long, 1-4 (5) mm broad, margins strongly to weakly revolute, entire, surfaces moderately to densely woolly-tomentose; petioles and stipules absent; buds plump, woolly, up to $2 \mathrm{~mm}$ long in the lower leaf axils; stems yellow-green with a moderate to dense white to silver-gray woolly tomentum, prostrate, branching with ascending tips, up to $35 \mathrm{~cm}$ long, from tough, wiry rhizomes; terminal internode (subtending the flower) similar in length to the one below, usually less than $6 \mathrm{~cm}$ long; root system perennial, fibrous, largely adventitious $(2 \mathrm{n}=36,72,90,108)$.

Infraspecific Variation: Notching and lobing of the petals is variable.

Note: Some plants reported as $C$. tomentosum in northeastern floras are referable to $C$. biebersteinii DC. (see above), but the definitive fruit character is often unavailable for study on herbarium specimens, since they are commonly collected in the showy, early stages of flowering.

Importance: This species is grown as a rock garden plant worldwide. It escapes cultivation primarily in temperate, Mediterranean and Austral climates, very rarely in New York. 


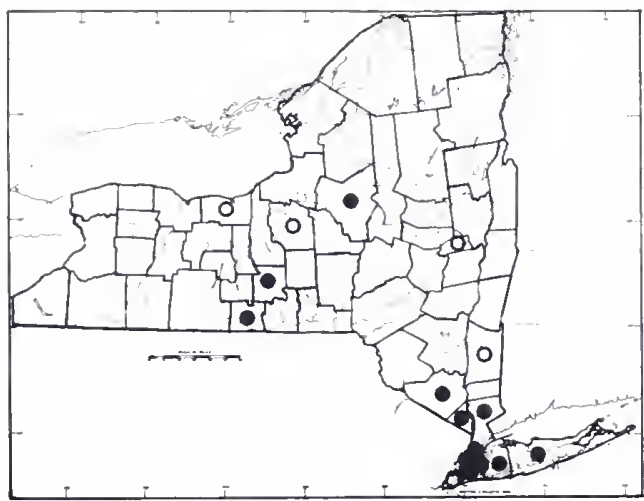

\section{Cerastium glomeratum Thuill.}

Common Names: Mouse-ear Chickweed

Type Description: Thuillier, Fl. Paris, ed. 2, p. 226, 1824

Synonyms: $C$. apetalum Dumort., $C$. glomeratum var. apetalum (Dumort.) Fenzl, C. viscosum of authors, not $\mathrm{L}$.

Origin: A native of Eurasia

Uabitats: Pastures, lawns, open woods, cultivated ground and urban clutter as a weed

IIabit: Sprawling to erect-ascending, annual herbs Flowering: (March) May-July

Fruiting: June-September

General Distribution: Southern Newfoundland, New York, Connecticut south to Florida, west to Kansas, Texas; British Columbia to California

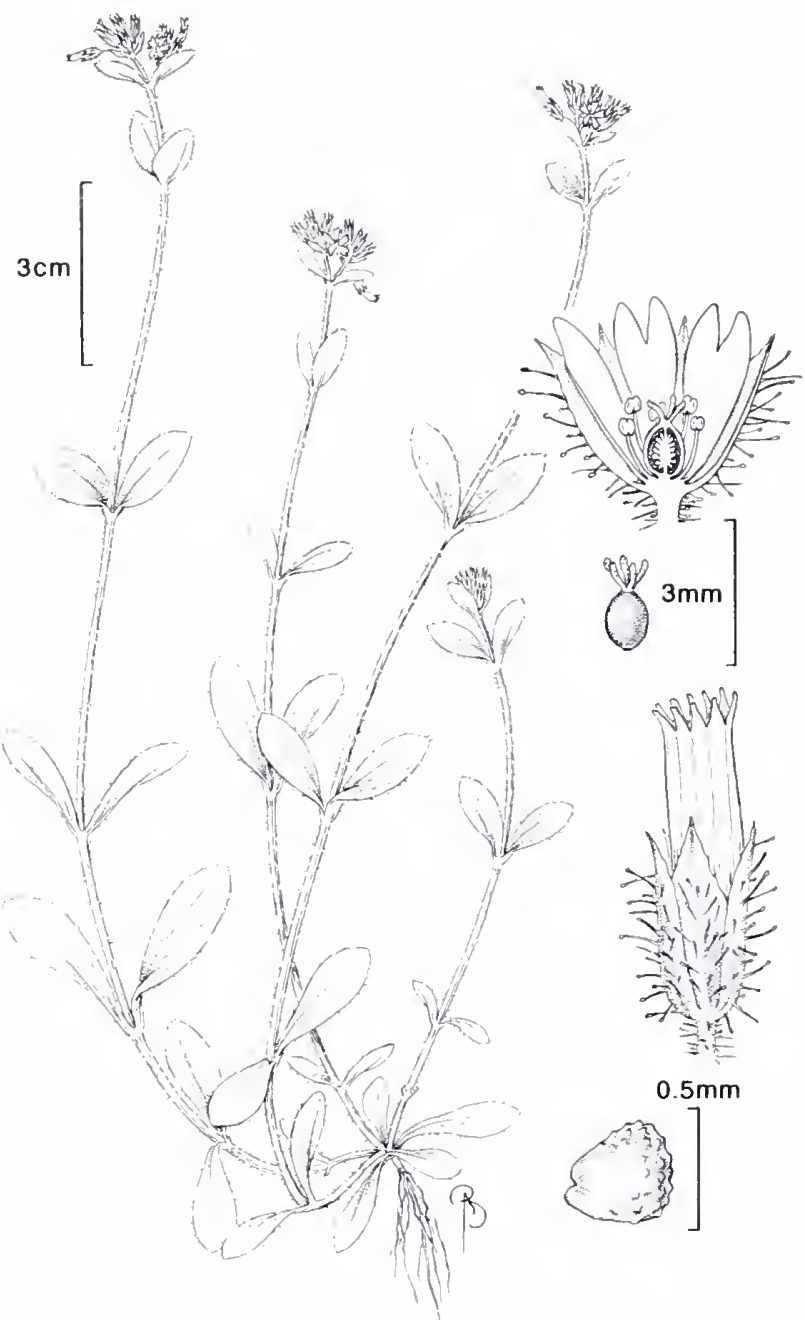

Description: Plants with bisexual flowers; stigmas 5, papillose; styles 5, linear to moderately clavate, 0.8-1.0 $\mathrm{mm}$ long; ovary 1, cylindric-ovoid, ca. $2 \mathrm{~mm}$ long; fruit a slender, cylindric capsule, golden, 4-9 (10) mm long, 1.2-1.8 $\mathrm{mm}$ broad, straight to slightly contorted, dehiscing by 7-10 irregular teeth at apex; seeds many, pale brown, sparsely papillose, 0.4-0.6 mm long, triangular (pyramidal); stamens 7-10, free; anthers minute, golden; filaments linear, 1-2 mm long; perianth of 2 free whorls of 5; petals 5 (sometimes fewer or lacking), white, bifid into two slender lobes, $3.1-5.5 \mathrm{~mm}$ long, almost equal to slightly exceeding the sepals; sepals 5 , ellipticlanceolate, $3.6-5.8 \mathrm{~mm}$ long, $0.7-1.4 \mathrm{~mm}$ broad, green below with the margins increasingly scarious toward the sharply acute to acuminate tips, adaxial surfaces glandular hispid, with hairs up to $1 \mathrm{~mm}$ long; pedicels $0.3-4.6$ (12) $\mathrm{mm}$ long, viscid; inflorescences loose, glomerate heads, or expanding into clusters of dense cymes through elongation of the peduncles by the time of fruiting; bracts herbaceous, broadly oval to ovate-lanceolate with obtuse (acute) tips, 2-12 $\mathrm{mm}$ long 1-10 $\mathrm{mm}$ broad, the lower ones paired, resembling reduced leaves, margins not scarious, even toward the tips, though the tip may be slightly paler (rarely with a pale mucro), surfaces sparsely to densely glandular-hispid; leaves ovate to elliptic, 0.4-3.2 (4) cm long, 0.3-1.5 (2) cm broad, reduced upward, the tips obtusely angled to rounded (or apiculate), the bases obtuse to attenuate, surfaces and entire margins moderately to densely hispid or sericeous; petioles absent, indistinct or up to $1.5 \mathrm{~cm}$ long with clasping bases, often hispid like the blade; stipules absent; stems lax to strongly ascending, often densely hispid, up to $60 \mathrm{~cm}$ long, sometimes (in ours) congested at base, showing a tendency to proliferate by lateral shoots; root system annual, a taproot or diffuse and finely branched $(2 n=72)$.

Infraspecific Variation: In some plants collected in North America there is a tendency to sprout at the base and produce marcescent shoots late in the season. Such variants are clearly like oiher $C$. glomeratum specimens morphologically, but with an aspect that has caused them to be mistaken for perennial $C$. fontanum Baumg. 
Occasionally inflorescences have a few elongate axes, especially in plants from the western part of the distribution range of the species, but ours consistently have glomerate inflorescences. Some populations have flowers with fewer than 5 petals, and in some places it is not uncommon to find plants in which most llowers lack petals; these were once recognized taxonomically as $C$. glomeratum var. apetalum (Dumort.) Fenzl. Importance: Noxious lawn weeds, especially in the southern states.

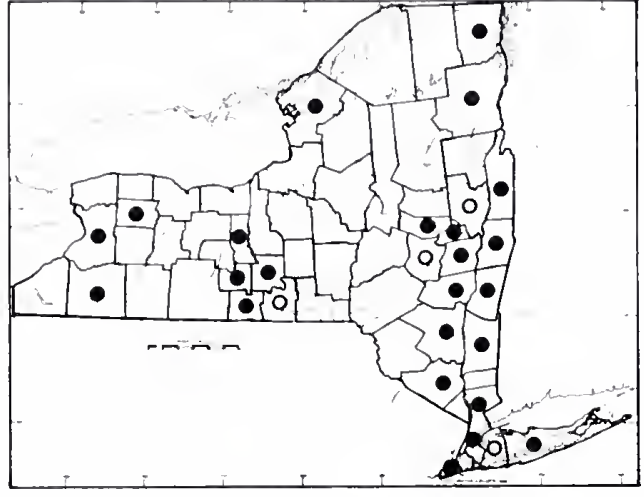

3. Cerastium nutans Raf.

Common Names: Nodding Chickweed, Powderhorn Type Description: Rafinesque, Prec. Decouvr., p. 36,1814

Synonyms: $C$. glutinosum Nutt., C.longipedunculatum Muhl. a nomen nudum, $C$. tenellum Fenzl

Origin: A widespread native of North America

Habitats: Cliffs, seeps and rocky woodlands

Iabit: Lax to ascending, sparsely-branched, annual herbs

Flowering: (March) April-July

Fruiting: May-September

General Distribution: (Nova Scotia) New Brunswick south to Georgia, Texas and Guatemala; on the West Coast: Mackenzic and British Columbia south to Arizona

Description: Plants with bisexual flowers; stigmas

5, papillose; styles 5, linear, 0.3-0.4 mm long; ovary

1, ovoid-cylindric; fruit a glossy, tan, somewhat translucent, cylindric capsule, often curved or contorted near the middle, when bearing mature seeds $8.5-12.0$ (15) $\mathrm{mm}$ long, 2.3-3.4 $\mathrm{mm}$ broad at the widest point near the base, dehiscing by 10 subequal teeth with revolute margins, seeds many, (0.5) 0.7-0.8 num long at maturity, comma-shaped, with a flat, dorsal ridge, light reddish-brown, the surfaces boldly tuberculate; stamens 6-10, free; anthers spheroid, golden, minute; filaments linear, ca. $2 \mathrm{~mm}$ long; perianth of 2 free series; petals 5 (or lacking) white, lanceolate to obovate, cleft or uncleft, $1-5(8) \mathrm{mm}$ long, often approximately equaling the sepals; sepals ovate to ovate-lanceolate, $3.5-5.7 \mathrm{~mm}$ long, $1.5-2.6 \mathrm{~mm}$ broad, green with hyaline margins, especially toward the tips, the adaxial surfaces and margins moderately to densely short glandular-villous, tips acute to bluntly cucullate, the bases rounded; pedicels $0.4-3.5(5.5) \mathrm{mm}$ long, slender, often reflexed just below the calyx in fruit; inflorescences of terminal cymes, sometimes dichotomously branched, often few-flowered or flowers in pairs, glomerate only when very young, the pedicels and peduncles elongated and recurved (hooked) in mature flower and fruit; bracts herbaccous, ovate to narrowly lanceolate, 2-14 mm long, 0.4-2.7 $\mathrm{mm}$ broad, sparsely to moderately glandular-hispid, especially on the margins; leaves $(0.4) 1-5(8.3) \mathrm{cm} l o n g$, $0.2-2.3 \mathrm{~cm}$ broad, elliptic to lanceolate or broadly oblanceolate, with acute to obtuse (sometimes apiculate) tips, and oblique bases, entire, the margins and surfaces usually covered with soft, glandular pubescence; 
petioles absent or indistinct; stipules absent; stems slender to somewhat stiff and stout, the larger ones often ridged and grooved, glandular pilose or hispid, 3-40 (60) $\mathrm{cm}$ long; root system slender, annual $(2 \mathrm{n}=34,36)$. Note: Plants with shorter, unreflexed pedicels, obtuse leaf tips and mostly small seeds (0.5-0.7 mm) occur to the south and west, where they are recognized as $C$. brachypodum (Engelm. ex Gray) Robins.

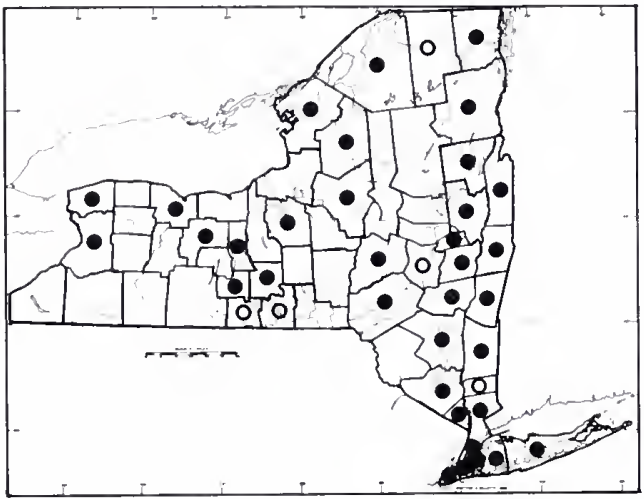

4. Cerastium arvense $\mathrm{L}$.

Common Names: Field Chickweed, Meadow Chickweed, Barren Chickweed

Type Description: Linnacus, Species P1. I., p. 438, 1753

Synonyms: $C$. arvense var. oblongifolium (Torr.) Hollick \& Britt., C. campestre Greene, $C$. oblongifolium Torr., $C$. occidentale Greene, $C$. pennsylvanicum Hornem. ex DC., C. pubescens Goldie, C. tenuifolium Pursh, C. velutinum Raf., C. villosum Muhl.

Origin: Circumboreal in range (possibly both native and introduced in New York State

Habitats: Ledges, rocky woods, meadows, fields and other disturbed ground

Ilabit: Loosely matted to tufted or cespitose, perennial herbs with lax to strongly erect branch tips

Flowering: April-August

Fruiting: May-September

General Distribution: In North America from Greenland to Alaska, south to California and Tennessee (Georgia); also native across Eurasia.

Description: Plants with bisexual flowers; stigmas 5, slightly swollen at the tips of the styles; styles 5 , free, 1.8$2.6 \mathrm{~mm}$ long; ovary 1, superior, ovoid; fruit a capsule, 6-11 mm long, 2-3 mm broad, tan, glossy, dehiscing by 8-10 terminal teeth with revolute margins; seeds (0.4) 0.6-0.9 (1.1) $\mathrm{mm}$ long, comma-shaped with 2 prominent dorsal ridges, red-brown with moderately to prominently tuberculate surfaces; stamens 8-10, free; anthers golden, oblong, ca. $0.9 \mathrm{~mm}$ long; filaments slender, $3-7 \mathrm{~mm}$ long; perianth of 2 free whorls of 5; petals white, 6-10 (16) $\mathrm{mm}$ long, $3-9 \mathrm{~mm}$ broad, the tips obtuse, entire (or fimbriate), emarginate or bilobed, cleft up to $1 / 4$ their length; sepals $4.5-8.9 \mathrm{~mm}$ long, $1-2 \mathrm{~mm}$ broad, elliptic, with acute to obtuse (notched) tips, green with scarious margins and tips, the adaxial surface glandular-pilose to moderately velutinous; pedicels 0.3-3.0 (4.2) $\mathrm{cm}$ long, glabrescent to pilose (or velutinous); inflorescences of terminal cymes with some single and paired flowers in the upper axils; bracts greenish with narrow to broad scarious margins toward the tips, 2-4 mm long, ca. $1 \mathrm{~mm}$ broad, hispid; leaves linear-acicular to elliptic-lanceolate, cauline leaves mostly 1-3 (7) cm long, 1-4 (9) $\mathrm{mm}$ broad, acute to acuminate (or blunted at tips), margins hispid, the surfaces glabrescent to hispid or pilose (rarely glandular); petioles and stipules absent; stems wiry, sparsely to densely retrorse-hispid or pilose (sometimes glandular), branched, matted and congested at the bases to lax and sprawling, the flowering branch 
tips lax to strongly ascending; short shoots commonly borne in the leaf axils, densely tufted with needle-like leaves; marcescent vegetative shoots commonly clustered at the stem bases; root system perennial, largely adventitious from wiry stolons $(2 \mathrm{n}=36,72,90,108)$.

Infraspecific Variation: This species is polymorphic, both in Eurasia and in North America, and cultivars have also been artificially bred for horticulture. Flower size, petal lobing, leaf shape, pubescence, capsule length and habit of the plant provide characters that have been historically used to delimit taxa within the complex. Further study has tended to proliferate the number of infraspecific taxa and contribute little to knowledge of the worldwide pattern of variation. Until a global study of the group is carried out, the use of polynomial designations is discouraged, except for convenience, where horticultural races are concerned.

Importance: Field Chickweed is grown as a rock garden plant around the world, and its many morphological variants occur widely as weeds as well as in their native habitats.

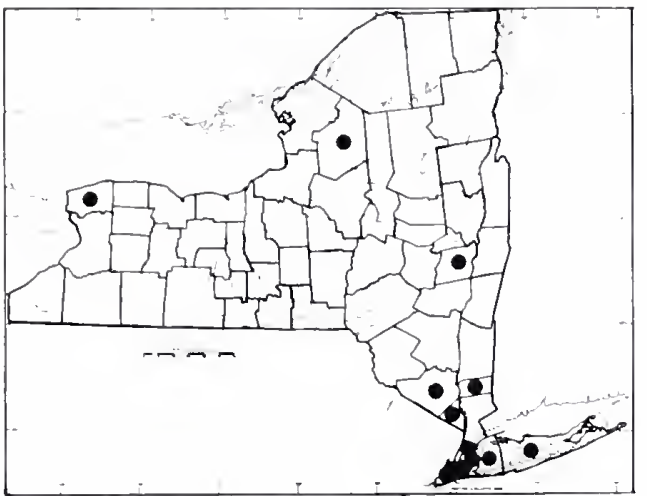

5. Cerastium semidecandrum $\mathrm{L}$.

Common Names: Small Mouse-ear Chickweed, Spring Chickweed

Type Description: Linnaeus, Species Pl. I., p. 438, 1753

Synonyms: $C$. vulgatum var. semidecandrum (L.) Gray

Origin: A native of Eurasia

IIabitats: Sandy, open places, especially on shores on the Coastal Plain and Lake Plains

IIabit: Decumbent to ascending, annual herbs, often diminutive and much branched at the base

Flowering: Late March-June

Fruiting: April-August

General Distribution: Eurasia; Massachusetts, New York and southern Ontario to the Great Lakes and Midwest, south to the Carolinas and Gulf Coast of Louisiana as an adventive

Description: Plants with bisexual flowers; stigmas 5, papillose up to $3 / 4$ the style length; styles 5, free, filamentous, ca. $0.8 \mathrm{~mm}$ long; ovary 1, superior, ovoid; fruit a greenish-tan, glossy, semi-opaque, cylindric capsule, straight or curved, $4.4-7.2 \mathrm{~mm}$ long, $1.1-1.5 \mathrm{~mm}$ broad, dehiscing by (9) 10 teeth with revolute margins; seeds many, comma-shaped, plump, 0.4-0.5 mm long, pale brown with a few prominent tubercles, or very weakly tubercled; stamens 5 (9-10), free; anthers minute, golden, filaments pale, linear, 2-3 mm long; perianth of 2 free whorls of 5 ; petals white, elliptic to lanceolate with obtuse or acute tips (or slightly notched), 2.1-3.2 $\mathrm{mm}$ long; sepals elliptic to ovate-lanceolate, $2.8-4.3 \mathrm{~mm}$ long, ca. $1 \mathrm{~mm}$ broad, green with broad, scarious margins toward the tips, sometimes tinged with purple, glandular to short-hispid on the adaxial surfaces; pedicels $1-9 \mathrm{~mm}$ long, erect or deflexed after anthesis, often densely glandular, short-hispid; inflorescences relatively dense terminal cymes, with a few flower pairs and clusters in leaf axils of robust individuals; bracts directly subtending the flowers, ovate to elliptic, $2-3 \mathrm{~mm}$ long, with scarious margins and tips (to almost entirely scarious), glandular-hispid, the lower bracts of the inflorescence more leaf-like and paired; leaves oval 
to elliptic-obovate or somewhat spatulate with obtuse tips, $2-8(13) \mathrm{mm}$ long, 2-7 $\mathrm{mm}$ broad, moderately to densely hispid to glandular; petioles and stipules absent; stems simple to much-branched from near the base, glabrescent to densely glandular-hispid, slender, ascending or decumbent, up to $25 \mathrm{~cm}$ long; root system an annual taproot with delicate lateral branches $(2 n=36)$.

Infraspecific Variation: Glabrous individuals are known in Europe, but none have been collected in our range. The stamens are usually five, but occasionally there are 9 or 10, the usual condition for plants of this genus. Taxonomic Note: Cerastium pumilum Curtis is a very similar European introduction that has been reported from Kings, Chemung and Steuben Counties. These plants have tetraploid $(2 n=72)$ chromosome numbers (or higher), and differ from $C$. semidecandrum in having more erect pedicels in fruit; the scarious bract tips and margins are less conspicuous, and the petals barely exceed the sepals.

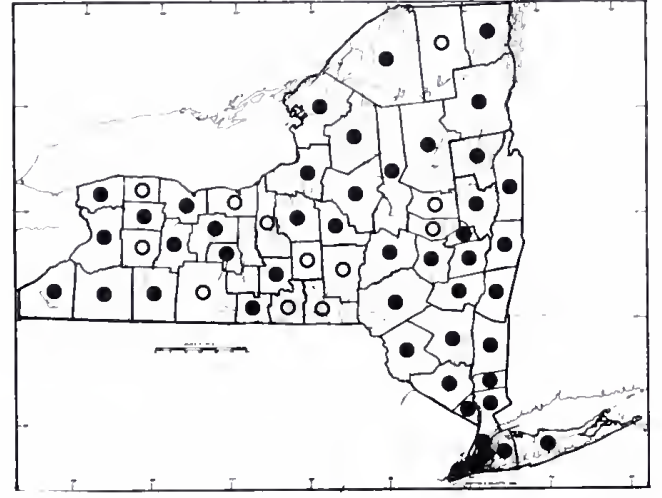

6. Cerastium fontanum Baumg. emend. Jalas ssp. vulgare (Hartm.) Greuter \& Burdet

Common Names: Mouse-ear, Common Chickweed Type Description: Baumgarten, Enum. Stirp. Trans. vol. 1, p. 425, 1816, emend. Jalas, Arch. Soc. Zool.-Bot. Fenn. Uanamo, vol. 18, p. 62, 1963

Synonyms: $C$. caespitosum Gilib., $C$. fontanum ssp. triviale of NY authors, not (Link) Jalas, $C$. holostoides Fries, $C$. glomeratum of authors, not Thuill., C. vulgatum of authors, in part.

Origin: A native of Europe

Ilabitats: Disturbed open sites: roadsides, lawns, meadows and fields to open woods and swamps

Ilabit: Spreading, matted, perennial herbs with ascending flowering shoots and short, marcescent vegetative shoots from basal rhizomes

Flowering: April-July (September-November)

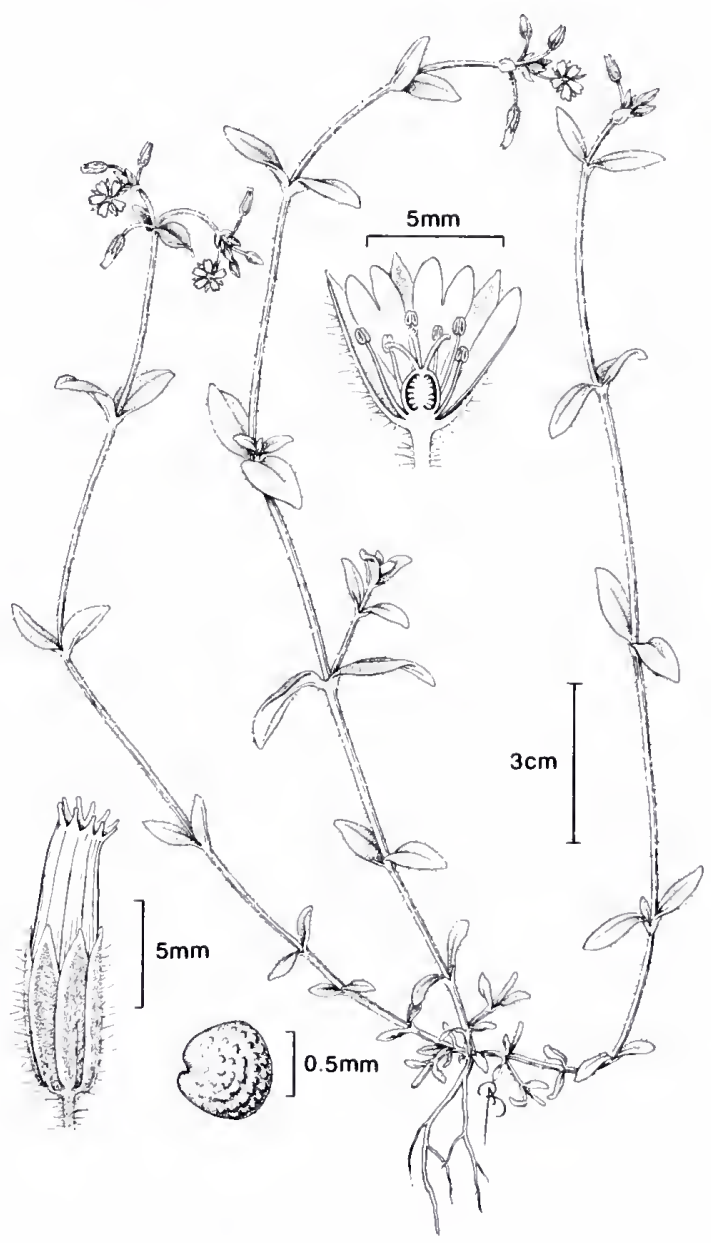

Fruiting: May-August (October-December)

General Distribution: Newfoundland to Alaska south to Mexico, Texas and Florida

Description: Plants with bisexual flowers; stigmas 5, papillose over 3/4 the style length; styles 5, free, capillary, 0.8-1.7 mm long; ovary 1, superior, ovoid; fruit a tan, glossy, somewhat translucent capsule, cylindric, usually curved, 6-10 (12) $\mathrm{mm}$ long, $1-3 \mathrm{~mm}$ broad, dehiscing by 8-10 teeth with revolute margins; seeds plump, trapezoidal to pyramidal, 0.4-0.7 (1.2) $\mathrm{mm}$ long, red-brown, with tubercles less than twice as wide as tall; stamens 5 (rarely 8-10), free; anthers golden, ovoid; filaments linear, $3-5(8) \mathrm{mm}$ long; perianth of 2 free whorls of 5 (or petals absent); petals white, $4-6 \mathrm{~mm}$ long, $1-3 \mathrm{~mm}$ broad, emarginate to bilobed, cleft up to $1 / 3$ of their length; sepals ovate-lanceolate, 5.2-8.3 (9) $\mathrm{mm}$ long, 1-3 mm broad, with acute to blunted tips, green or reddish-tinged with hyaline margins and tips, the midvein prominent at the sepal base; pedicels 1-9 (13) $\mathrm{mm}$ long, reflexed just below the calyx in fruit, densely hirsute (glandular); inflorescences glomerate at first, usually elongating to become open, terminal cymes; bracts at the inflorescence base paired, leaf-like, the floral bracts above ovate, 1-3 mm long with scarious margins toward the tips, hispidulous with ciliate margins; 
leaves lance-ovate, strap-like, elliptic, obovate or spatulate, 3 times longer than wide (or more), the tips usually obtuse (mucronate or acute), with entire margins, $2-35$ (41) mm long, 1-12 (15) mm broad, hirsute (to glandular) on both surfaces and margins; petioles and stipules absent; stems decumbent or ascending up to $70 \mathrm{~cm}$, hirsute to glandular with marcescent vegetative shoots at base and matted stolons and rhizomes; root system largely adventitious $(2 \mathrm{n}=72,144,162)$.

Infraspecific Variation: This is an extremely variable species in Europe, where it is native and widespread as a weed. In New York State, plants similar to ssp. fontanum in sepal size occur, but these often have smaller seeds. They have recently been treated as ssp. triviale (Link) Jalas., even though ssp. triviale is said to differ from its nearest relatives in Europe by having a combination of short sepals and small seeds, with prominent, symmetrical tubercles. The trend in European infraspecific classification has been to recognize plants like those found in eastern North America as ssp. vulgare (Hartman) Greuter \& Burdet. Three of four subspecies in the European flora are reported to have the same high chromosome number $(2 n=144)$, so introgression may well have occurred. Varieties of so-called $C$. vulgatum L. treated in North American manuals were based on variable pubescence and leaf shape not consistent enough to warrant recognition.

Importance: A noxious weed, very persistent in lawns and gardens, and resistant to most herbicides.

\section{MOEIRINGIA}

Common Name: Sandwort

Authority: Linnacus, Species PI. 1, p. 359, 1753

A circumboreal, but primarily Eurasian genus of 30 species, two of which occur as natives in North America.

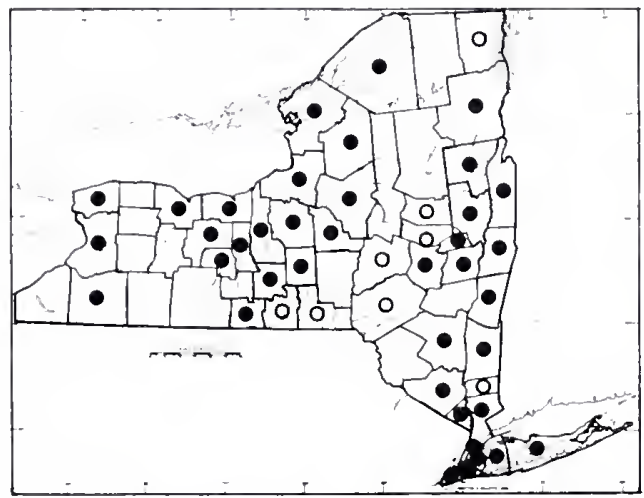

1. Moehringia lateriflora (L.) Fenzl

Common Names: Grove Sandwort, Blunt-leaf Sandwort

Type Description: Linnacus, Species Pl. I., p. 423, 1753

Synonyms: Arenaria angustifolia Regel, A. lateriflora L., Stellaria biflora Pursh

Origin: Circumboreal

Ilabitats: Woodland borders, swamps, meadows, thickets and shores, in moist, mucky or gravelly soils

Habit: Rhizomatous, perennial herbs with spreading branches

Flowering: May-August

Fruiting: June-October

General Distribution: Circumboreal in temperate areas; North America from Newfoundland to Alaska, south to New Mexico and Maryland

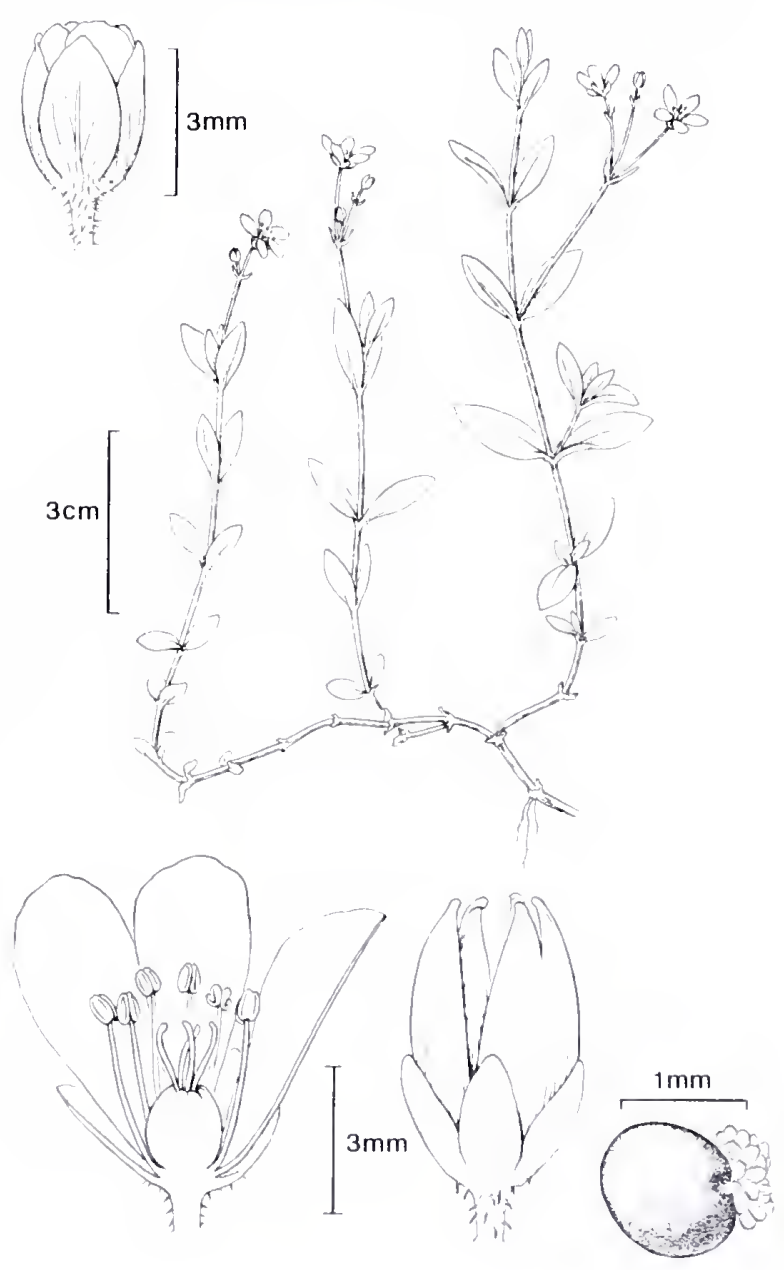


Description: Plants with bisexual flowers (plants sometimes functionally dioecious); stigmas 3-4 (5), slightly expanded at style tips; styles 3-4 (5), borne at the tips of the ovary lobes, sometimes 2 (3) styles from a single lobe, united below; ovary 1, superior, 3-5 (6) lobed above, the lobes sometimes appearing like distinct carpels (the extreme ones clavate-tipped), ovary apex elongating and expanding between the lobes during fruit development; fruit a tan, lustrous capsule, ovate-lanceolate to conic, $3-7 \mathrm{~mm}$ long, $1.4 \mathrm{~mm}$ broad, with acute, lobed tips, dehiscing to become (5) 6 toothed, often more deeply 2-cleft to near the base along opposite sutures, the teeth erect to somewhat spreading; seeds several, red-brown to almost black, coarsely rugulose, ovoid, 0.9-1.3 mm long, often with a pale, spongy strophiole at maturity; stamens (8-) 10 (11), free; anthers globose, ca. $0.2 \mathrm{~mm}$; filaments linear, $2-4 \mathrm{~mm}$ long; perianth of 2 distinct, free whorls; petals 5 , white to pinkish, ovate-obovoid, 3.4-7.0 (8.3) $\mathrm{mm}$ long, 2.0-6.7 mm broad; sepals 5, elliptic to obovate, 2.1-3.1 mm long, 0.8-1.6 mm broad, entire with obtuse to acute tips, weakly to strongly 3 -nerved the central nerve often lined with short, bristle-like hairs, surfaces pale green with hyaline margins; pedicels slender, 0.4-1.7 (2.3) $\mathrm{cm}$ long, yellow-green, with few to many minute, retrorsely hooked hairs; bracts subtending the pedicels and peduncles paired, 1-2 mm long, linear to broadly lanceolate, puberulent; peduncles like the pedicels, up to $4 \mathrm{~cm}$ long; flowers often borne in terminal pairs (or singly), sometimes overtopped by a flower from an inflorescence axil, or inflorescence a 3-4 (6-) flowered cyme; leaves paired, elliptic-ovate to narrowly oblong, (0.3) $1-3(3.7) \mathrm{cm}$ long, (0.2) $0.6-2.5 \mathrm{~cm}$ broad, entire with obtuse bases and obtuse to subacute tips, obscurely clasping at base, the surfaces glandular-punctate, puberulent to short-villous on the margins and adaxial veins; petioles lacking; stipules lacking; stems slender, greenish to pinkish-tan, glabrous to retrorsely puberulent or densely shortvillous, especially at the nodes, laterally branching, the main axis somewhat weak and sprawling, mostly 10-20 (up to 40) $\mathrm{cm}$ long; rhizome slender and often extensive, with scale-like leaves at the nodes; root system fibrous, adventitious $(2 \mathrm{n}=24,48)$.

Infraspecific Variation: This species ranges to northern Eurasia, where most other species of the genus occur as endemic relicts. Its unusual variation in floral structure suggests that it is among the more primitive members of the family, possibly having evolved as far back as the Cretaceous. In early stages of development, the ovary may be swollen, with inconspicuous terminal lobes, or the lobes may be elongate and club-like, with appearance of separate carpels when viewed from above. The whole aspect of the flower is much like that of a saxifrage prior to fruit development. The somewhat erratic development of the ovary leads to some variation in size and morphology of the mature fruits, which range from small, primarily 2-valved structures bearing only a few ripe seeds through a series of larger capsules, the best developed of which dehisce by 5-6 teeth and split to near the fruit base. Moehringia macrophylla Hooker is a closely related, widespread species in North America, differing from ours in leaf, bract, sepal and capsule shapes. Its distribution range is primarily Western Cordilleran, but it occurs sporadically in the east, and as close to New York as Vermont. 


\section{ARENARIA}

Common Names: Sandwort, Starwort

Authority: Linnacus, Species PI. I, p. 423, 1753

A genus of up to 300 species of primarily Old World plants, many of which are sun-loving and occur in sandy and rocky habitats. In this publication, Minuartia and Moehringia and Honckenya, often considered congeneric with Arenaria in earlier North American floras and manuals, are treated separately.

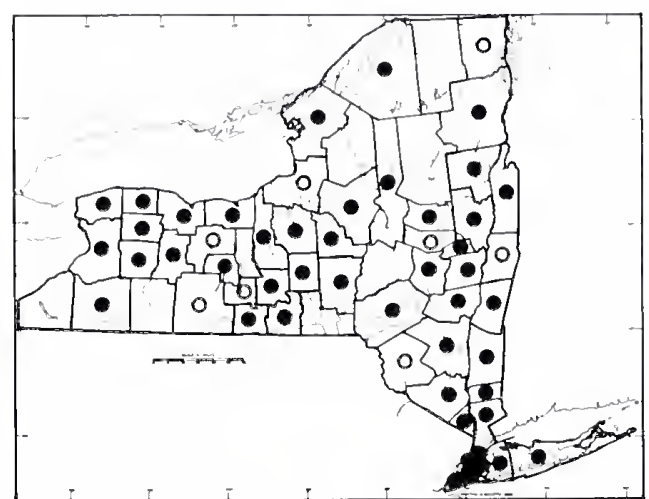

1. Arenaria serpyllifolia $\mathrm{L}$.

Common Names: Thyme-leaf Sandwort

Type Description: Linnacus, Species Pl., p. 423, 1753

Synonyms: A. leptoclados (Reich.) Guss, A. serpyllifolia ssp. leptoclados (Reich.) Nymer; $A$. serpyllifolia var. tenuior Mert. \& Koch, A. tenuior (Mert. \& Koch) Gürke

Origin: A native of Eurasia

Habitats: Dry, sunny, sandy or gravelly waste places, fields, roadsides, quarries and ledges

Ilabit: Annual herbs, often profusely branched with slender taproots

Flowering: April-September

Fruiting: May-November

General Distribution: A native of Europe and northern Asia, widespread as a weed virtually throughout the temperate world

Description: Plants with bisexual flowers; stigmas 3, papillose areas at the style tips; styles 3, filiform, spreading, ca. $0.7 \mathrm{~mm}$ long; ovary 1, superior, ovoid; fruit an olive-tan, glossy capsule, pyriform to cylindric, $3-5 \mathrm{~mm}$ long, ca. $3 \mathrm{~mm}$ broad near base, dehiscing by 6 triangular, apical teeth; seeds many, golden to dark brown, semi-glossy, rugose, reniform, 0.5-0.7 mm long; stamens 6-8 (10), free; anthers minute, golden, globose; filaments thread-like, 0.5-1.2 mm long; perianth of 2 distinct, free whorls; petals 5, obovate, 1.3-2.4 mm long, entire or minutely notched at tip, white; sepals 5, ovate at base with lance-acuminate tips, $1.8-3.6 \mathrm{~mm}$ long, 0.4-1.0 mm broad at base, glandular-hispid on the adaxial surface, the central 1/2-2/3 of the structure a green band with 1-3 (3-5) major veins, the midrib usually prominent, margins hyalin; pedicels 1-14 mm long, minutely glandular-hispid, sometimes retrorsely; bracts minute, leaf-like up to $6 \mathrm{~mm}$ long and $3 \mathrm{~mm}$ broad; peduncles like the pedicels; inflorescence a diffuse dichasium with single flowers pairs and clusters borne terminally and in the axils throughout all but the lower portions of the plant; leaves oval to ovate-lanceolate, acute to acuminate or apiculate, with obtuse, minutely clasping bases, 1-6 (8) $\mathrm{mm}$ long, 0.6-5.4 mm broad, the surfaces glandular punctate or pustulose, scabrescent (to glandular-hispid), especially along the veins and entire leaf 
margins; petioles absent; stipules absent; stems wiry, usually much-branched from near the base, sparsely to densely, retrorse-scabrescent, $3-30(36) \mathrm{cm}$, spreading; root system a slender, annual taproot $(2 \mathrm{n}=20,40)$. Infraspecific Variation: Some authors have recognized up to four subspecies of $A$. serpyllifolia, including a taxon based on slightly shorter, more cylindric capsules and a more delicate vegetative habit. These characters have been used to distinguish $A$. leptoclados from $A$. serpyllifolia L. Plants reported as $A$. serpyllifolia var. macrocarpa Lloyd (a nomen illeg.), from the Atlantic coast of Europe, also occur in New York State. These are distinctive in appearance in that the upper leaves and bracts are broad and often crowded beneath shortpedicelled flowers at the stem apices.

\section{MYOSOTON}

Common Names: Giant Chickweed, Water Mouse-ear

Authority: Moench, Meth., p. 225, 1794

A monotypic genus of the Old World, historically included in the genus Stellaria.

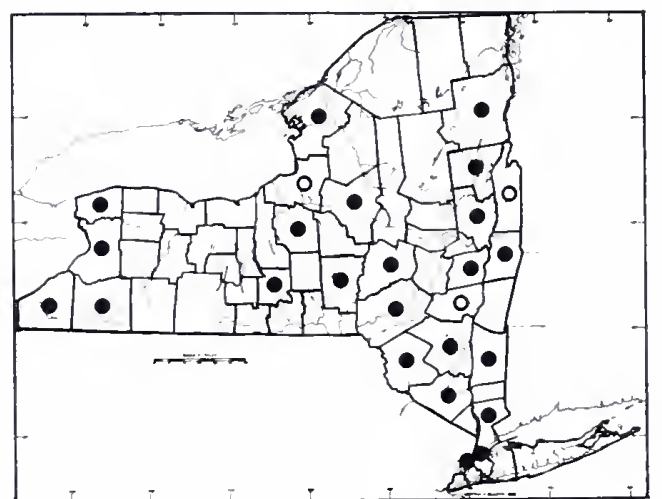

1. Myosoton aquaticum (L.) Moench

Common Names: Giant Chickweed, Water Mouseear (Chickweed)

Type Description: Linnaeus, Species P1. I., p. 439, 1753

Synonyms: Alsine aquatica (L.) Britt., Cerastium aquaticum L., (Malachia) Malachium aquaticum (L.) Fries., Stellaria aquatica (L.) Scop.

Origin: A native of northern Europe

Habitats: Stream courses and shores, wet meadows, thickets, swamp clearings and moist waste places

Habit: Sprawling to ascending, perennial herbs

Flowering: (May) June-October

Fruiting: June-November

General Distribution: A native of Europe, naturalized in North America from New England to Minnesota (also B.C.), sporadically southward to Missouri and the Carolinas (Louisiana)

Description: Plants with bisexual flowers; stigmas 5, papillose zones lateral to the styles and ca. $1 / 2$ their length; styles 5, filamentous, 1.6-2.0 mm long, free, divergent to recurved; ovary 1, superior, ovoid, ca. $2.5 \mathrm{~mm}$ long; fruit an ovoid-cylindric to pyriform capsule, $5-9$ (10) $\mathrm{mm}$ long, 3-6 mm broad, greenish to tan, smooth, dehiscing apically by 5 valves each bifid into 2 narrow teeth ca. $1 \mathrm{~mm}$ long; seeds numerous, 0.7-0.9 mm long, brown, orbicular to reniform and prominently tuberculate to papillate, especially on the dorsal surface; stamens (9) 10, free; anthers elliptical, up to $1 \mathrm{~mm}$ long; filaments linear, 2.1-3.8 mm long; perianth of 2 free 
whorls of 5 ; petals white, obovate to narrowly spatulate, $5-11 \mathrm{~mm}$ long, $2-3$ (4) $\mathrm{mm}$ broad; sepals ovate to lance-acuminate, greenish to somewhat hyaline, $4-9(10) \mathrm{mm}$ long, $2-4 \mathrm{~mm}$ broad, viscid, glandular- puberulent on the adaxial surfaces; pedicels mostly 1-2(3)cm long, slender, viscid, glandular-pilose, often recurved in fruit; inflorescences few-flowered terminal cymes, or flowers borne singly and in pairs in the uppermost axils of leaves and leaf-like bracts; leaves with a strong central vein, largely glabrous but viscid- puberulent primarily along margins and lower veins; upper cauline leaves $1-5(8) \mathrm{cm}$ long, 0.5-3.0 (4.5) $\mathrm{cm}$ broad, sessile, ovate to broadly lanceolate with acute to acuminate tips, bases obtuse to somewhat cordate, one lobe sometimes larger, inconspicuously clasping, sometimes with winged petioles up to a $\mathrm{cm}$ long; lower cauline leaves up to 9 by 4 $\mathrm{cm}$, often cordate, sometime with winged petioles; stems loosely branched, often sprawling, $5-50(80+) \mathrm{cm}$ long, somewhat ridged and angled, viscid, glandular-pilose to hispid or glabrous, especially those on lower stems in contact with water; root system perennial, adventitious at the lower nodes $(2 \mathrm{n}=20$ ?, 28$)$.

\section{STELLARIA}

Common Names: Chickweed, Stitchwort, Starwort

Authority: Linnaeus, Species Pl. 1, p. 421, 1753

A genus of $100+$ species, widespread in open habitats, especially in temperate climates, but also occurring also as weeds almost throughout the world. They are of little value to man except for the widespread species $S$. media (L.) Vill., which is sometimes used in salads and folk medicine.

Description: Plants with bisexual flowers; stigmas (2) 3 (4-6); styles (2) 3 (4-6), free; ovary 1, superior; ovules many, borne on a free, central placenta; fruit a globose to ovoid-cylindric capsule, dehiscent by (4) 6 (8-10) teeth to the middle or near the base; seeds many, plump, tuberculate or smooth; embryo curved; stamens (2-8) 10; filaments slender, free; anthers globose; perianth of 2 free whorls, or the petals may be lacking; petals (04) 5 , deeply bifid for $2 / 5$ their length or more, often white; sepals (4) 5 , greenish; pedicels slender; bracts scarious or herbaceous; inflorescences dichasial, cymose, or flowers borne singly and in pairs in axils or terminal to main stems and lateral branches; leaves paired, ovate to linear, connate-clasping at base; petioles lacking (or winged); stipules absent; stems decumbent, lax to robustly erect; root system annual or perennial.

\section{KEY TO SPECIES}

1. Flowers often $1 \mathrm{~cm}$ in diameter or more; sepals $6-8(11) \mathrm{mm}$ long $\ldots \ldots \ldots \ldots \ldots \ldots$ (2)

1. Flowers inconspicuous, usually less than $1 \mathrm{~cm}$ broad; sepals mostly less than $6 \mathrm{~mm}$ long ....... (3) 2. Leaves strap-like, lance-elliptic to linear-lanceolate with acuminate to aristate tips ... . 1. S. holostea

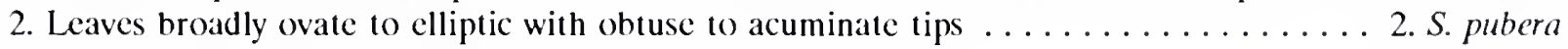

3. Mature cauline leaves $6-30$ times as long as broad, sessile . . . . . . . . . . . . . . (5)

3. Mature cauline leaves $2-4$ (5) times as long as broad, the middle and lower ones often with winged

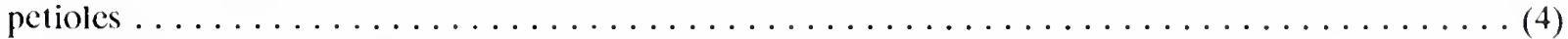

4. Inflorescence bracts membranaceous, hyaline margined; bracts and sepals lanceolate. ... 3. S. alsine

4. Inflorescence bracts herbaceous; bracts and sepals elliptic to ovate . . . . . . . . . . 4. S. media

5. Flowers borne singly in leaf axils and in few-flowered, terminal cymes; floral bracts herbaceous; petals absent or much-reduced, shorter than the sepals; mature capsules strongly exserted, up to 2-3 times the sepal

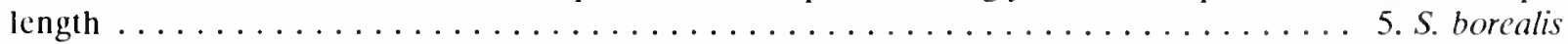

5. Flowers borne in terminal or lateral, few to many-flowered cymes; floral bracts scarious; petals shorter to much longer than the sepals (rarely absent); mature capsules usually less than twice the sepal length (6) 6. Mature capsule slightly to strongly exserted from the calyx, appearing dark, due to pigmented walls or brown seeds visible through the hyaline capsule wall; inflorescence bracts usually glabrous, entire (7) 6. Mature capsule included or barely exserted from the calyx, pale tan and opaque; most inflorescence

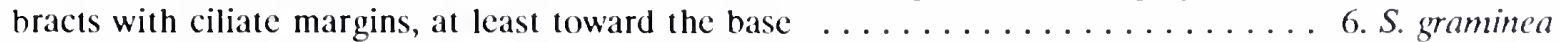

7. Leaf margins minutely papillose; mature inflorescences (and infructescences) broadly divaricately branched; dehisced capsule greenish-tan to brown, often hyaline, the dark seeds visible within ... . 7. S. longifolia

7. Leaf margins very smooth, pale, not minutely papillose; mature inflorescence (and infructescence) branches ascending; dehisced capsule dark purple-brown to almost black . . . . . . . . . 8. S. longipes 


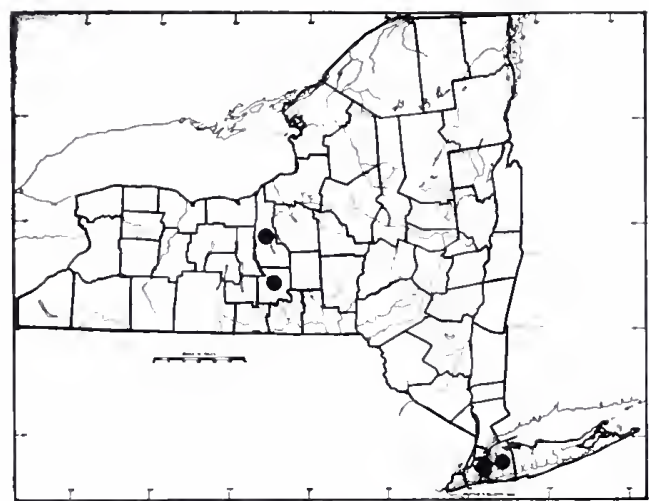

1. Stellaria holostea L.

Common Names: Greater Stitchwort, Easter-bell, Great Starwort, Snakegrass, Lady's-lint

Type Description: Linnacus, Species Pl. I, p. 422, 1753

Synonym: Alsine holostea (L.) Britt.

Origin: Native to boreal Eurasia

IIabitats: Sandy roadsides and limy woods (in New York)

Ilabit: Ascending, perennial, rhizomatous herbs

Flowering: (late April) May-June

Fruiting: June-July

General Distribution: Escaping cultivation in eastern North America, persisting from New Brunswick to West Virginia; also moderately weedy in its native Europe, the Near East and North Africa

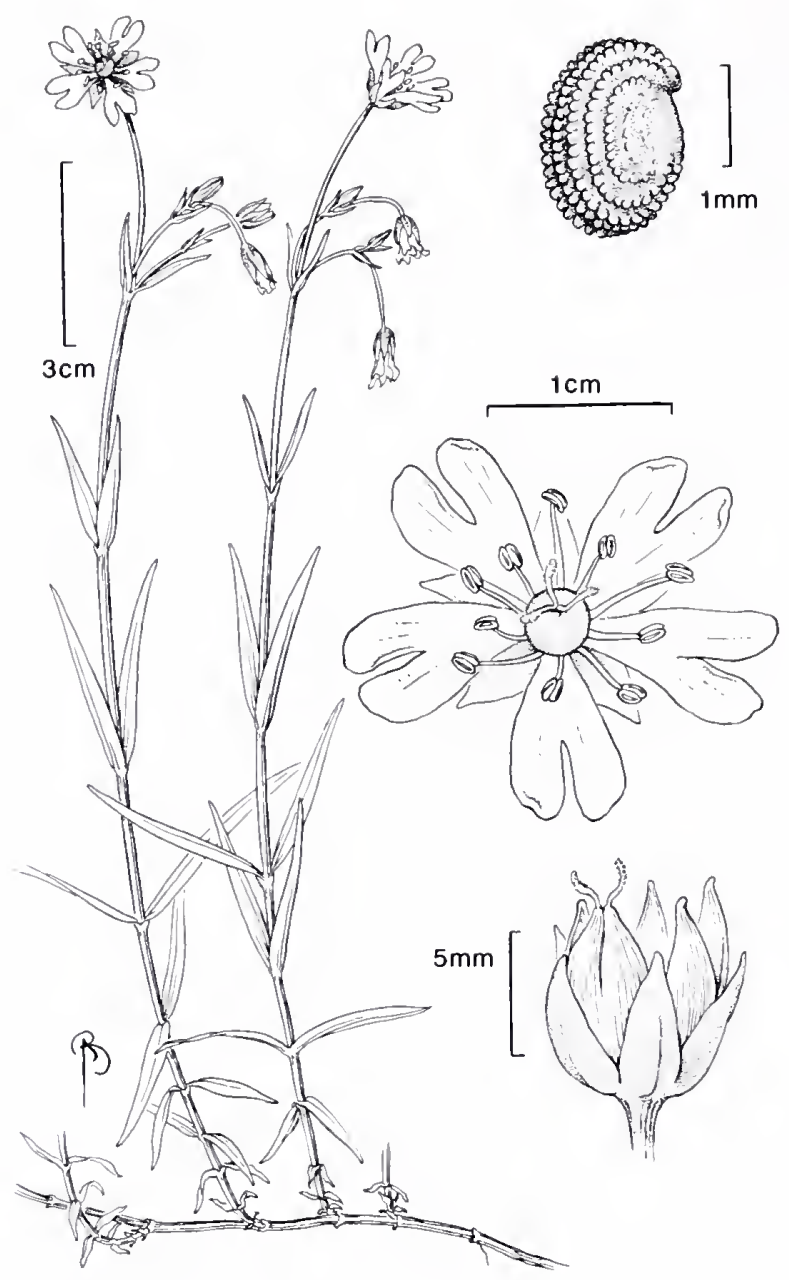

Description: Plants with bisexual flowers; stigmas 3, papillose, linear near the style tips; styles 3, linear, 2.5-3.2 $\mathrm{mm}$ long, free to base; ovary 1, superior, spheroid to oval; fruit a capsule, tan, lustrous, opening by 6 teeth, globose, ca. 5-6 mm long and broad; seeds many, brown, 1.8-2.3 mm broad, dolabriform to reniform, with 2 papillose, dorsal ridges; stamens 8-10, free; anthers golden, elliptic, 0.5-1.1 mm long; filaments 4-6 mm long, linear; perianth of 2 free whorls of 5; petals 8-12 (17) $\mathrm{mm}$ long, 3-5 (8) $\mathrm{mm}$ broad, showy, white, bifid from 2/5-3/5 their lengths into broadly rounded lobes; sepals elliptic-lanceolate with acute, acuminate (or apiculate) tips and rounded cup-like bases, 5-8 (9) mm long, glabrous, greenish with entire, hyaline margins; pedicels slender, somewhat angled, scabrescent, up to $2.8 \mathrm{~cm}$ long; inflorescences terminal and subterminal, fewflowered cymes; bracts herbaceous, $2-12 \mathrm{~mm}$ long, lanceolate, scabrous along lower margins; leaves (1) 2-5 (8) $\mathrm{cm}$ long, $2-8 \mathrm{~mm}$ broad linear to lanceolate (elliptic-lanceolate) with acuminate to aristate tips, not conspicuously clasping at the sessile bases, mostly glabrous on the surfaces, but rough-scabrous on the margins and lower midrib; petioles absent; stipules absent; stems weakly to strongly ascending, with scabrous ridges, 10-40 $(80) \mathrm{cm}$ long at the time of flowering; rhizome slender, jointed, with slightly swollen nodes, sometimes bearing minute, fusiform, pinkish buds; root system slender, largely adventitious at the rhizome nodes $(2 \mathrm{n}=26)$. Importance: This is one of the few chickweeds showy enough to be grown as a garden perennial. They are occasionally used as early-blooming rock garden plants, with flowers up to three centimeters broad. 


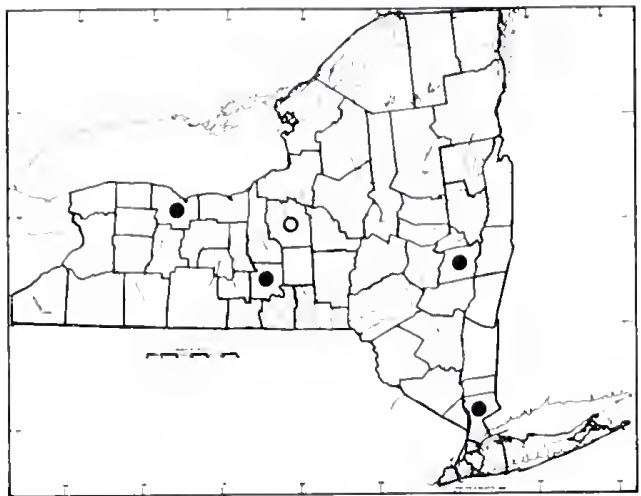

2. Stellaria pubera Michx.

Common Names: Great Chickweed, Star Chickweed

Type Description: Michaux, Fl. Bor. Am., vol. 1, p. 273, 1803

Synonyms: Alsine pubera (Michx.) Britton (see additional synonymy under varieties)

Origin: Native to Appalachian North America

IIabitats: Cool woodlands and open, disturbed places in New York, where it is a rare weed

IIabit: Ascending perennials with relatively short flowering shoots in spring, followed by taller, primarily vegetative stems

Flowering: (April) May-June

Fruiting: June-July

General Distribution: Connecticut and New York State as a rare adventive; Native: New York? (New Jersey) Pennsylvania, Illinois, south to Tennessee, Alabama, Georgia, North Florida

Deseription: Plants with bisexual flowers; stigmas 3, papillose the style tips; styles 3, linear, 2.5-3.3 mm long; ovary globose; fruit a tan, lustrous capsule, $3.2-5.5 \mathrm{~mm}$ in diameter, opening by 6 teeth that tend to recoil on dehiscence; seeds many, 1.6-1.9 mm broad, reniform, pale brown, papillose; stamens (8) 10, anthers elliptic, golden-brown, ca. $0.5 \mathrm{~mm}$; filaments slender, pale, $3-4 \mathrm{~mm}$ long; perianth of 2 free whorls of 5; petals white, cleft $1 / 2$ to $7 / 8$ their length into 2 entire lobes, $5-12 \mathrm{~mm}$ long, $2-5 \mathrm{~mm}$ broad, shorter than, or exceeding the calyx; sepals $4-11 \mathrm{~mm}$ long, $1.0-2.8 \mathrm{~mm}$ broad, ovate to elliptic lanceolate with rounded bases and bluntly acute to strongly acuminate tips, greenish with hyaline margins, lustrous, reticulate veined at base, glabrous or villous at abaxial surface near the base and on the receptacle; pedicels mostly $1-2 \mathrm{~cm}$ long, slender, angled, totally villous or with 1-2 bands of villous pubescence; inflorescences terminal or subterminal, few-flowered cymes or flowers borne singly or in pairs in the upper axils of primarily vegetative shoots; bracts scarious to green, 1-4 mm long, lanceolate, the larger ones ciliate at base; leaves ovate to narrowly elliptic-oblong, mostly 1-8 (11) $\mathrm{cm}$ long, 0.8-2.5 (3.5) $\mathrm{cm}$ broad, pustulose, glabrous except villous on margins and lower midrib, sessile or with winged petioles up to $2 \mathrm{~cm}$ long; stipules absent; stems ascending, $5-30 \mathrm{~cm}$ tall, 4 -angled with villous hairs, particularly on upper stems, flowering early, then producing more vigorous, primarily vegetative shoots up to $40 \mathrm{~cm}$, from a tough, pale rhizome; root system fibrous, primarily adventitious from the nodes of the rhizomes.

Infraspecific Variation: Two ploidy levels are known, with features that have lead some students of the group to recognize two species. Stellaria corei Shinners is the correct name at the species level for plants with conspicuously attenuate, glabrous sepals and a tendency for the leaves to be petiolate. Plants from near Rochester, New York, however, exhibit distinct petioles and shorter, acute to blunt sepals typical of $S$. pubera, while largely lacking adaxial pubescence. I choose to recognized these taxa at the varietal level. 


\section{KEY TO VARIETIES}

1. Sepals mostly 4-6 mm long, acute to obtuse, often puberulent on the adaxial surface; petioles lacking (or only the $1-3$ lowermost leaves with evident petioles) $\ldots \ldots \ldots \ldots \ldots \ldots \ldots$. . . . pabera

1. Sepals mostly 7-10 mm long, conspicuously acuminate, glabrous on the adaxial surface (sometimes pubcrulent at base); middle and lower leaves often petiolate . . . . . . . . . 2b. var. sylvatica

\section{2a. Stellaria pubera var. pubera}

Synonyms: Alsine pubera var. tennesseensis Mohr., A. tennesseensis (Mohr.) Small

Origin: Native to the Appalachians of the southeastern United States

Habitats: This diploid variety $(2 \mathrm{n}=30)$ is known in New York State from a single specimen from a wooded area near Rochester, where its origin is questionable; although it is well north of its natural range, there is a possibility that it is native in New York State (as in the Chicago area)

2b. Stellaria pubera var. sylvatica (Bég.) Weatherby

Synonyms: S. corei Shinners, S. sylvatica (Bég.) Maguire

Origin: Native to the Appalachians and midwestern U. S.

Ilabitats: This tetraploid variety $(2 n=60)$ has been found both escaped from cultivation and spreading in existing gardens in New York State

Importance: Both varicties of Stellaria pubera are occasionally cultivated, but usually south of our range. One specimen of $S$. pubera var. sylvatica was collected in an Albany County garden "spreading rapidly."

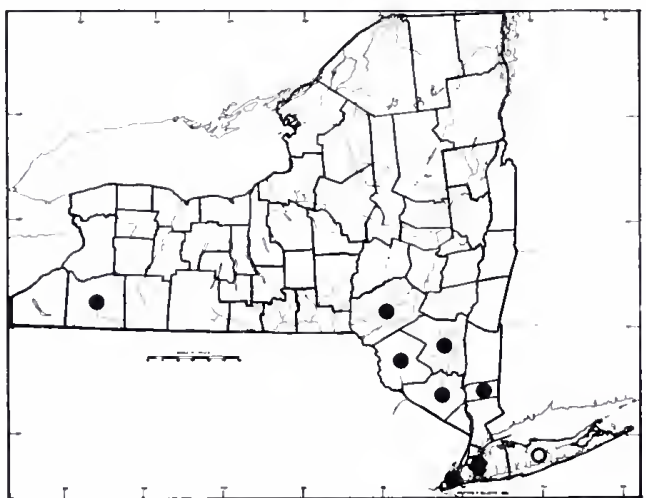

3. Stellaria alsine Grimm

Common Names: Marsh Chickweed, Bog Starwort, Stitchwort

Type Description: Grimm, Nova Acta Acad. Leop.Carol., vol. 3, app: 313, 1767

Synonyms: Alsine uliginosa (Murr.) Britt., $S$. uliginosa Murr.

Origin: A native of northern Eurasia

Irabitats: Moist ledges, springs and streambeds as a weed

Ilabit: Lax, decumbent to ascending annuals or biennials, often sprawling with ascending leaves

Flowering: May-October

Fruiting: May-December

General Distribution: Native of Northern Eurasia that occurs sporadically as a weed from Newfoundland to Maryland (Tennessee), Minnesota, British Columbia and Washington State

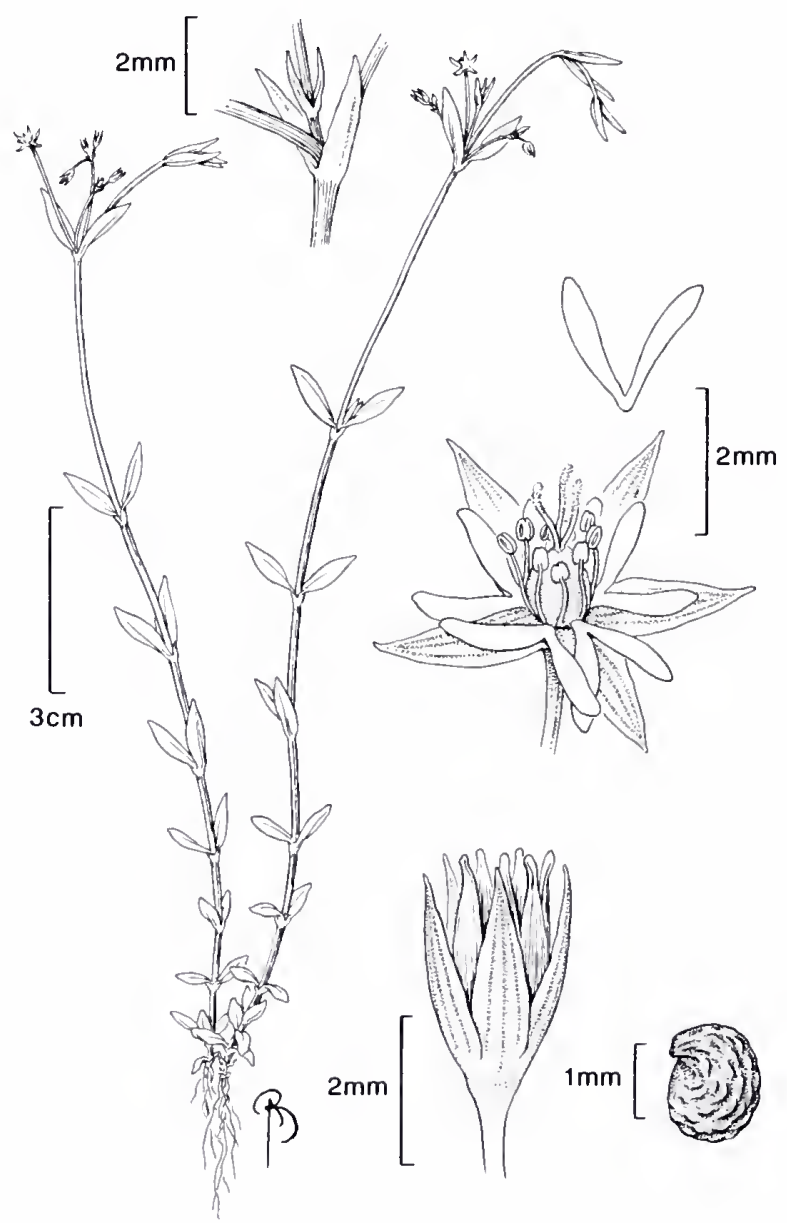


Description: Plants with bisexual flowers; stigmas 3; styles 3, linear, ca. $0.5 \mathrm{~mm}$ long; ovary 1, superior, ovoid; fruit an ovoid, greenish to tan capsule $2.0-3.5 \mathrm{~mm}$ long, dehiscing by 6 narrow tecth; seeds several to many, brown, plump, 0.5-0.8 mm, rugulose with narrow ridge-like protuberances; stamens 10, free; anthers pale, globose, minute; filaments slender, ca. $1.5 \mathrm{~cm}$ long; perianth of 1 or 2 whorls of 5 ; petals lacking or white, less than $1.5 \mathrm{~mm}$ long, sometimes falcatte or contorted; sepals $1.8-3.3 \mathrm{~mm}$ long, lanceolate, with acute to acuminate tips, entire, eciliate, pale greenish with three prominent green veins; pedicels mostly $3-5 \mathrm{~mm}$ long, slender, glabrous or with a few villous hairs; inflorescences primarily lateral, few-flowered cymes or pairs (flowers rarely solitary); bracts of the inflorescence lanceolate, $2-3$ (4) $\mathrm{mm}$ long, scarious with a minute green midrib, entire or occasionally toothed or bifid; leaves elliptic to ovate-lanceolate, mature cauline leaves 6-16 (22) mm long, 2-12 mm broad, entire, glabrous or minutely ciliate on margins; petioles absent or winged, up to $6 \mathrm{~mm}$ long, sometimes with a few villous hairs at the margins; stipules absent; stems angled, up to $40 \mathrm{~cm}$. long, lax, decumbent-sprawling to ascending; root system slender, much branched $(2 n=24,26)$.

Infraspecific Variation: These plants vary considerably in leaf size and shape, the more robust leaves of some individuals being strongly petioled.

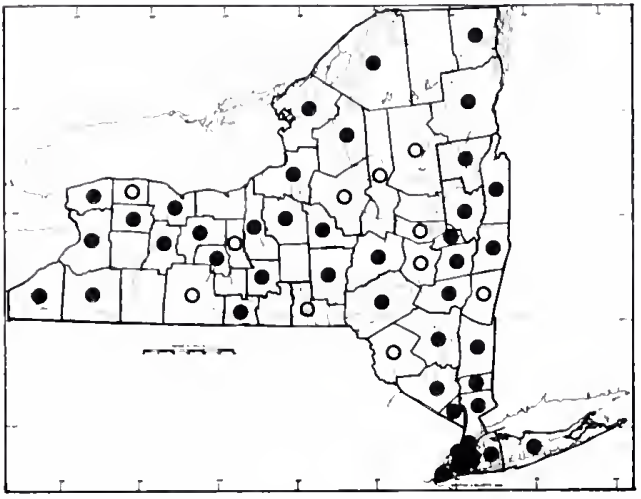

\section{Stellaria media (L.) Villars}

Common Names: Common Chickweed, Satinflower, Tongue-grass

Type Description: Linnacus, Species P1. I, p. 272, 1753

Synonyms: Alsine media L., A. pallida Dumort., in part, $S$. apetala Bernard., of some authors, not Ucria, S. media (L.) Cyrillo, of some authors, $S$. media var. glaberrima G. Beck, $S$. media var. procera Klett \& Richt., $S$. neglecta Weihe in Bluff \& Fingerhut, S. pallida (Dumort.) Jung., not Piré

Origin: A native of northern Eurasia

Ilabitats: Waste places, roadsides, cultivated ground, meadows, open woods, borders and lawns

Iabit: Matted, sprawling to ascending perennials (or annuals)

Flowering: (All year) April-December in NY

Fruiting: All year

General Distribution: A native of Eurasia and a cosmopolitan weed, especially of cultivated or otherwise disturbed ground

Description: Plants with bisexual flowers only or polygamous, with stamens lacking in some flowers; stigmas usually 3 , papillose along much of the length of the styles; styles usually 3 , pale, linear, arched outward, 0.5-0.8 $\mathrm{mm}$ long, free to base; ovary 1, superior, ovoid; fruit a somewhat translucent to greenish-tan capsule, 3.0-4.5 (5.5) $\mathrm{mm}$ long, $2-3 \mathrm{~mm}$ broad, ovate to cylindric, dehiscing by 6 narrow teeth; seeds several to many, brown, 
0.9-1.5 mm long and broad, reniform, unevenly tuberculate, often prominently on the 2 dorsal ridges, rugulose along the sides; stamens free, 2-10 (or absent in some flowers); anthers minute; filaments slender, pale, 1-2 $\mathrm{mm}$ long; perianth of 1 or 2 free whorls; petals $1-5$ (or absent), white, 1-2 (3) mm long, deeply bifid to near the base, the lobes linear to slightly broadened at tips, enclosed or barely surpassing the calyx; sepals 5, free, (1) $2-5$ (7) $\mathrm{mm}$ long, $1-3 \mathrm{~mm}$ broad, ovate with obtuse to acute tips, greenish with hyaline margins, pustulose, the adaxial surfaces and margins sparsely to densely villous; pedicels 2-20 (27) mm long, villous, at least along one side; inflorescences cymose, terminal and lateral with flowers sometime single in the upper leaf axils; bracts leafy, similar to the leaves, but some as small as $2 \mathrm{~mm}$ long; leaves with blades 3-26 (35) mm long, 1-20 (30) $\mathrm{mm}$ broad, elliptic to broadly ovate-orbicular, entire with obtuse to acute or apiculate tips and attenuate to broadly rounded bases, upper leaves smaller, sometimes pubescent when young but usually glabrous and merely villous only along the lower margins; petioles absent to strongly developed on the larger cauline leaves, up to $2.5 \mathrm{~cm}$, usually with villous margins; stipules absent; stems angled and grooved, with vertical lines of villous hairs alternating with glabrous channels or entirely villous or, less often glabrous, matted or sprawling up to $50(90) \mathrm{cm}$, weakly ascending at tips, bases weak, horizontal or vertical, often persisting over winter in association with a pale, finely fibrous root system $[2 \mathrm{n}=40,42,44(18,22)]$.

Infraspecific Variation: This is a member of a polymorphic group that has been split into several species and subspecies in its native Eurasia on the basis of stem and leaf pubescence and sizes of sepals, petals and seeds. The two diploids $(2 \mathrm{n}=22)$ from which Stellaria media was possibly derived are recognized at the species level in Europe as $S$. pallida (Dumort.) Junger and $S$. neglecta Weihe or maintained as varieties of $S$. media (Behnke, 1976; Tutin et al., 1964) This polymorphic species-complex has ploidy variants and a number of morphological combinations that do not consistently correlate with them, eg., plants escaped in Mediterranean climates (as in California) may be relatively succulent with 1-3 petals and stamens.

Importance: Common chickweed is relatively well known as a pot herb. Although reported to have little flavor, it is sometimes boiled with spinach to add bulk. The greens are also steeped with dandelion stalks to produce a somewhat bitter mixture. In folk medicine, chickweed leaves (dried or fresh) have been added to poultices and ointments used for various curative purposes, particularly in treating discomforts of the skin and eyes. Decoctions have been used internally for a number of ailments, from coughs to constipation. There is no evidence of its effectiveness as an "old wives" remedy for obesity. The fourth most widespread species in the world, $S$. media is sometimes a noxious weed of lawns and gardens with a marked resistance to conventional herbicides. It has been widely studied in terms of ecology, embryology, cytology, genetics, ultrastructure and biochemistry, and there is a large and growing list of metabolic end products for the species. 


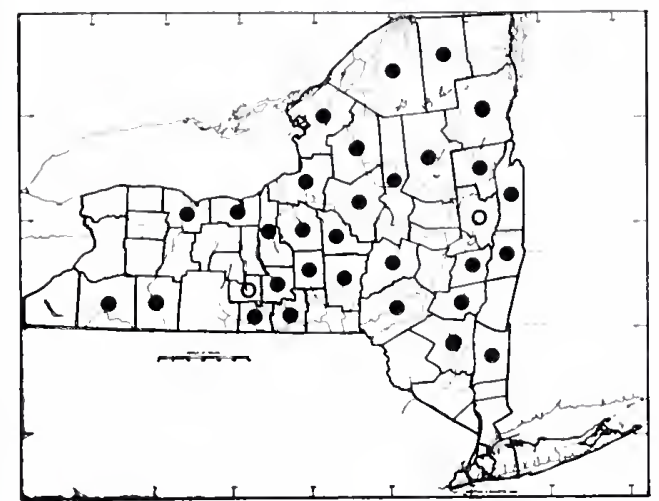

5. Stellaria borealis Bigelow

Common Names: Northern Starwort or Stitchwort Type Description: Bigelow, Fl. Bost. ed. 2, p. 182, 1824

Synonyms: Alsine borealis (Bigel.) Britt., Bigelowia montana Raf., S. calycantha of NY reports, not (Ledeb.) Bong. (including Fernald's varieties)

Origin: Circumboreal and subarctic

Habitats: Mossy alpine talus, seeps and stream beds; cold, wet forests, marshes, sphagnum bogs, fens and shores

Habit: Creeping to strongly ascending, stoloniferous, perennial herbs (sometimes cespitose in Eurasia)

Flowering: June-August

Fruiting: July-September

General Distribution: Greenland to Alaska (Eurasia) south to California, Utah, Pennsylvania and West Virginia

Description: Plants with bisexual flowers; stigmas 3 or $5(4,6)$ papillose lines extending to near the style base from the tips, (which may be bifid); styles 3 or 5 (4,6), 1.0-1.4 mm long, filamentous, occasionally with a bifid tip up to $0.5 \mathrm{~mm}$ long; ovary 1, ovate; fruit an ovate to cylindric capsule, 3.1-5.4 (6) $\mathrm{mm}$ long, 1.5-3.2 $\mathrm{mm}$ broad, dehiscing by 6 narrow teeth 1/2-2/3 its length (or sutures not all equally splitting), surface glossy greenish-tan or purplish-tinted, somewhat hyaline at maturity, appearing darker due to the seeds inside; seeds many, plump lenticular, dark brown, minutely rugulose, 0.7-0.9 mm long; stamens 6-10, free; anthers minute, yellow to reddish, globose; filaments slender, 1-2 mm long; perianth of 1 or 2 whorls; petals absent or up to 5 , bifid or only a single lobe, white to translucent, usually less than $1 \mathrm{~mm}$ long and not equaling the sepals; sepals 1.9-2.8 (4.6) $\mathrm{mm}$ long, 0.7-1.4 mm broad, lance-ovate with acute to obtuse tips, pale green with hyaline margins, usually entire; pedicels mostly $1.2 \mathrm{~cm}$ long, slender, inconspicuously angled and twisted, glabrous, borne singly in the lower leaf axils, and in pairs or small, cymose inflorescences at the branch tips; bracts leaflike, herbaceous, as small as $1 \mathrm{~mm}$ long, lanceolate to lance-ovate, intergrading with the leaf pairs or with a more abrupt transition when cymose, the margins entire and glabrous or ciliate; leaves $0.8-5.5(7) \mathrm{cm}$ long, 4-8 (11) $\mathrm{mm}$ broad, linear to lance-ovate or elliptic with acute to acuminate tips, sheathing obscurely at base, with a strong midrib, surfaces glabrous, margins glabrous, scabrescent or sparsely villous, especially near the leaf bases; petioles and stipules absent; stems lax to strongly ascending, ribbed and channeled, glabrous, from stolons and slender rhizomes; root system perennial, primarily adventitious, delicate $(2 \mathrm{n}=44,48,52)$.

Infraspecific Variation: The plants may appear heterophyllous or homophyllous, depending upon the abruptness of transition between sizes of leaves associated with terminal cymes when they are present. Leaves, and flower parts are somewhat variable in size between individuals and populations. Five described varieties, based on such characters intergrade "insensibly" (Fernald, 1950), and do not deserve recognition. 


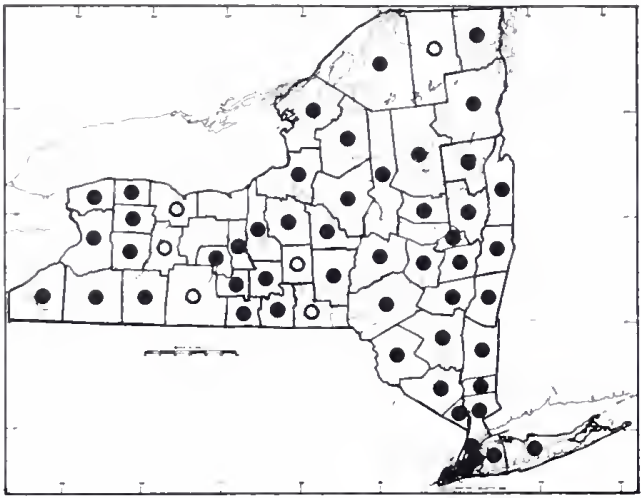

6. Stellaria graminea L.

Common Names: Common Stitchwort, Lesser Stitchwort or Starwort

Type Description: Linnaeus, Species Pl. I, p. 422, 1753

Synonym: Alsine graminea (L.) Britt., S. graminifolia Salisb., S. montana Raf.

Origin: A native of Europe

Habitats: Grassy places, lawns, roadsides, meadows, pastures and streamsides, often in moist soil in full sunlight

IIabit: Decumbent, perennial herbs with weakly trailing stems and ascending branch tips

Flowering: May-October

Fruiting: June-December

General Distribution: Newfoundland to Manitoba, south to Missouri and South Carolina; also introduced in Washington, ldaho and California, but less common there; widespread and weedy in its native Europe as well

Description: Plants with bisexual flowers; stigmas 3, each a papillose line, extending ca. $1 / 3$ the style length; styles 3,1.9-2.6 mm long, filamentous; ovary 1, ovoid; fruit an ovoid to cylindric capsule 3.6-5.3 (6) $\mathrm{mm}$ long, $1-3 \mathrm{~mm}$ broad with opaque, tan walls, dehiscing apically to ca. 1/2 its length by 6 narrow, blunt-tipped teeth, the tip usually included in the persistent perianth; seeds many, 0.7-1.0 (1.2) $\mathrm{mm}$ long, plump-lenticular, some with a pronounced dorsal ridge, rugulose to regularly furrowed, red-brown; stamens 6-10, free; anthers globose, golden; filaments slender 4-7 mm long; perianth of 2 whorls of 5 (petals rarely absent); petals 5 (or fewer, rarely absent), white, usually deeply bifid, 2-6 mm long; sepals 5, elliptic-lanceolate to almost linear, with narrowly acute to attenuate (sometimes mucronate) tips, 4.4-7.6 mm long, 1.0-2.6 mm broad, surfaces shiny greenish, 3-nerved, occasionally puberulent below with hyaline margins that are usually ciliate, at least toward the base; pedicels slender, glabrous, 0.6-3.0 (4.3) cm long, divergent, often borne at right angles to the axis of the inflorescence at maturity; inflorescences primarily terminal, lax, often much-branched, cymes with up to 60 flowers each; bracts scarious, lanceolate, mostly 2-4 mm long, nearly always ciliate-margined, at least toward the base; leaves (linear to) lance-elliptic, mostly $1-5(-7.6) \mathrm{cm}$ long, $1-7(-9) \mathrm{mm}$ broad, midrib strong, surfaces glabrous, but margins usually ciliate, at least near the clasping bases; petioles absent; stipules absent; stems angled and grooved, lax and stoloniferous or sprawling below, somewhat ascending near the tips, usually glabrous, up to $70(90) \mathrm{cm}$ long; root system weak, fibrous, perennial $(2 \mathrm{n}=26,39,52)$.

Infraspecific Variation: Plants with broader, less grass-like leaves have been called $S$. graminea var. latifolia Peterm. in Europe. Young plants are often misidentified as S. longifolia Muhl. ex Willd. or S. longipes Goldic, but the sharper, star-like sepals, strongly ciliate bracts and more furrowed seeds of $S$. graminea usually allow 
correct identification. Three ploidy levels (including sterile triploids) have been recorded in European populations.

Importance: These plants can be noxious weeds of lawns, and they are noticeably resistant to conventional herbicides.

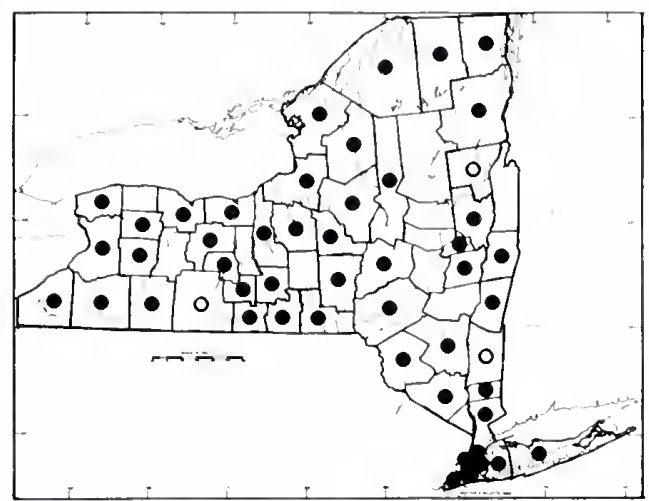

7. Stellaria longifolia Muhl. ex Willd.

Common Names: Needle-leaf Starwort

Type Description: Muhlenberg ex Willdenow, Enum. Pl. Hort. Berol., p. 479, 1809

Synonyms: Alsine longifolia (Muhl. ex Willd.) Britt., S. friesiana Ser. ex DC., S. longipes var. laeta (Richardson) S. Wats., S. tenella Raf.

Origin: Circumboreal

Ilabitats: Seepage areas and moist soils of meadows, swamps, open forests, thickets; also vernally moist talus, pavement barrens and ditches

IIabit: Lax to ascending perennials from a branching rhizome systems

Flowering: May-July

Fruiting: May-September

General Distribution: Circumboreal: in North America from Newfoundland to Alaska, south to New Mexico, Missouri and Tennessee

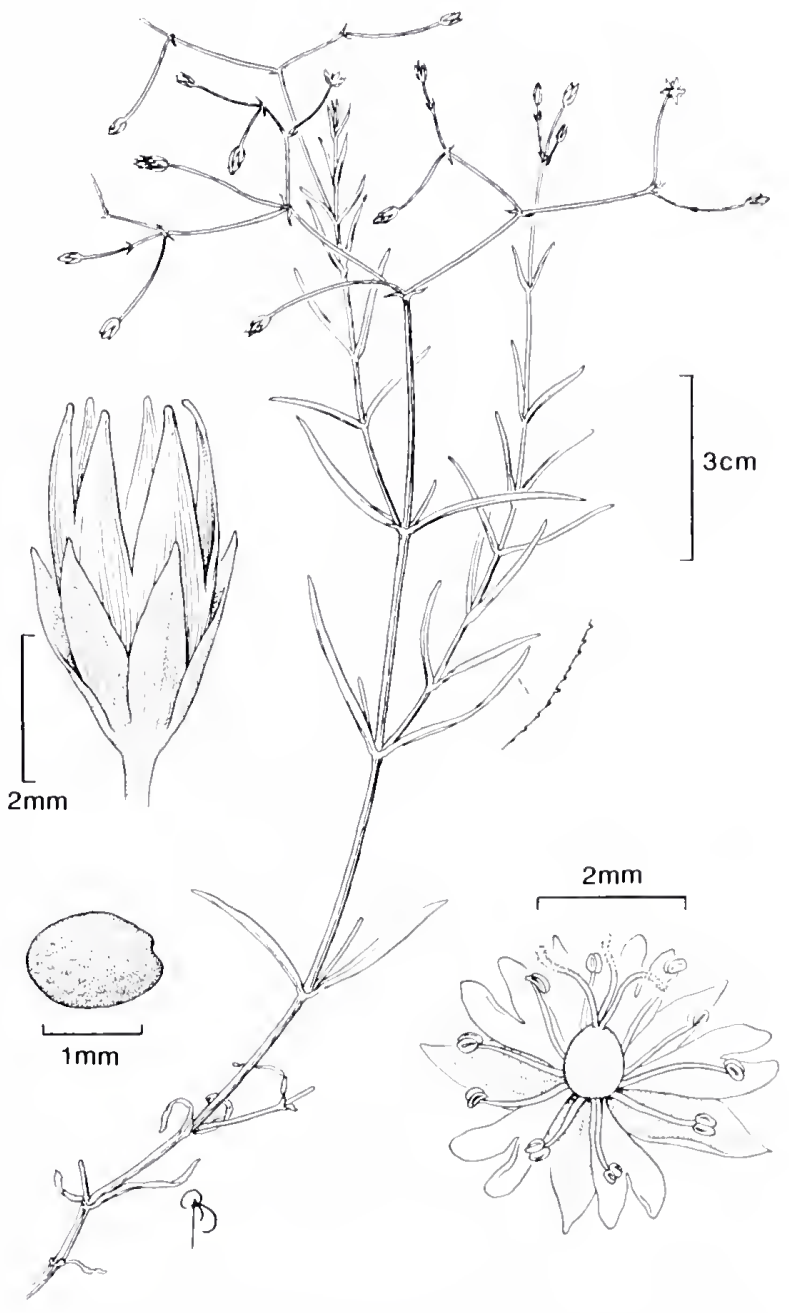

Description: Plants with bisexual flowers; stigmas 3, each a papillose line from the style tip to ca. $1 / 2$ its length; styles 3, 1-2 mm long, linear, free; ovary 1, ovoid; fruit an ovoid to narrowly cylindric capsule, 3.8-4.9 $\mathrm{mm}$ long, 1.5-2.7 mm broad, glossy greenish to tan (brown), often hyaline before dehiscence, the dark seeds visible through the fruit walls; seeds numerous, ca. $0.8 \mathrm{~mm}$ long, plump to lenticular with a dorsal ridge, redbrown, rugulose to almost smooth; stamens 6-10, free; anthers elliptic, golden, minute; filaments $2.9-4.1 \mathrm{~mm}$ long, extremely slender; perianth of 2 free whorls of 5; petals 5 (rarely fewer), bifid, white, 2.3-4.8 mm long, shorter to equaling or slightly longer than the sepals; sepals $2.6-4.2 \mathrm{~mm}$ long, elliptic, with acute to apiculate tips, not strongly veined, glabrous, glaucous green, with hyaline margins that may be ciliate, but usually are not; pedicels very slender, glabrous, elongating with age from a few $\mathrm{mm}$ (when the flower is in bud) up to 3 (4) $\mathrm{cm}$ in fruit; bracts lanceolate, usually with eciliate, entire or ragged margins, mostly 1-3 mm long, scarious, but sometimes with a greenish midrib; inflorescences lateral, appearing terminal to stems and lateral branches, cymes with their axes ascending at first, but becoming divaricately branched with age; leaves $0.7-5.0(7) \mathrm{cm}$ long, 1-7 (12) $\mathrm{mm}$ broad, stiff, ascending, linear to lanceolate (elliptic-lanceolate) with acute tips, or tips appearing acute but minutely blunted, bases clasping, midrib strong, the surfaces usually glaucous and pale green and glabrous, margins revolute, minutely papillose, glabrous or sparsely ciliate toward basc; petioles absent; stipules absent; stems glabrous, glaucous, sharply angled and grooved, lax to ascending, up to $50(80)$ $\mathrm{cm}$ long, $20 \mathrm{~cm}$ tall, from slender rhizomes; root system delicate, mostly adventitious $(2 \mathrm{n}=26)$. 
Infraspecific Variation \& Hybridization: Leaves and stems are sometimes dark green, lacking the typical pale, glaucous sheen; when this is true, however, the plants may be told from the following species by their minutely papillose leaf margins divaricate infructescences and less pigmented capsules. Sepals may be ciliate or not. Artificial triploid hybrids $(2 \mathrm{n}=39)$ have been produced through crosses with $S$. longipes (Chinnappa, 1985a), and natural hybrids (also $2 \mathrm{n}=39$ ) are reported with $S$. borealis (Morton \& Rabeler, 1984).

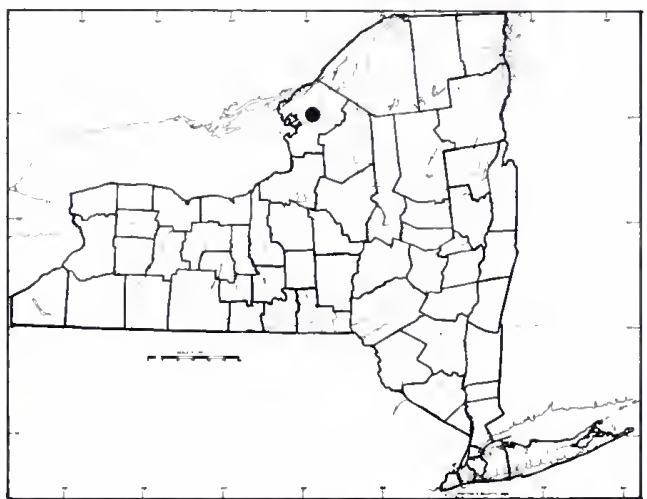

\section{Stellaria longipes Goldie}

Common Names: Starwort, Long-stalked Stitchwort Type Description: Goldie, Edinb. Phil. Jour., vol. 6, p. 327,1822

Synonyms: Alsine longipes (Goldie) Cov., S. crassifolia S. Wats., not Ehrh.

Origin: Circumboreal

Habitats: Limestone cliffs, ledges, shallow soil over flatrock and calcareous arbor-vitae swamp margins; alvar, grassy slopes and meadows in New York State (elsewhere: clearings in rocky, boreal forests and tundra)

IIabit: Sprawling perennial herbs with ascending branch tips

Flowering: May-July

Fruiting: June-August

General Distribution: Circumboreal; Greenland and Quebec to Alaska south to California, Colorado, Michigan and northwestern New York; also native in boreal Eurasia

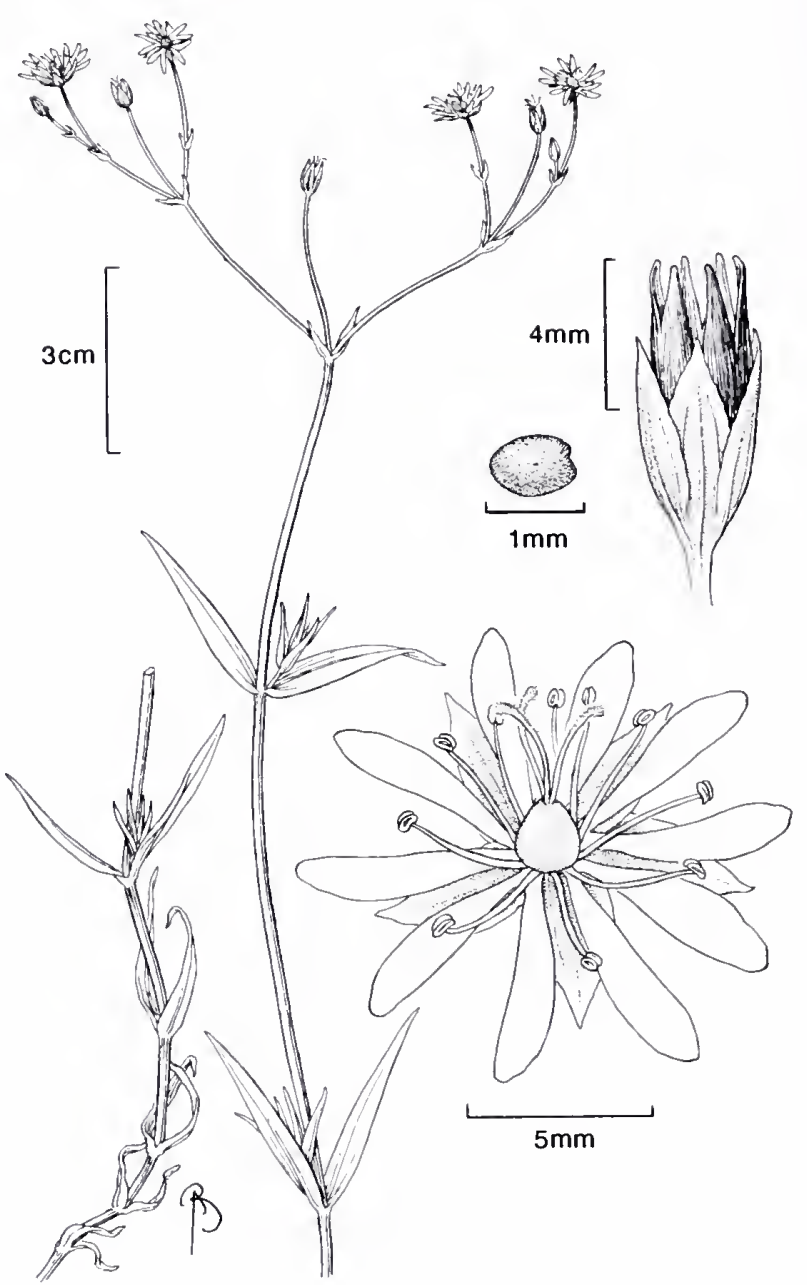

Description: Plants with bisexual flowers; stigmas 3, each a papillose line on the upper $2 / 3$ of the style; styles 3 , slender, free, 2-3 mm long; ovary 1, ovoid; fruit an ovoid to narrowly cylindric capsule, 5.1-7.6 mm long, 1-4 $\mathrm{mm}$ broad, opaque, dark purple-brown to almost black at maturity, strongly exserted, dehiscing by six slender valves, the sutures splitting about $1 / 2$ the length of the capsule (or some adhering) seeds many, 0.8-1.2 $\mathrm{mm}$ long, plump, oval, without a pronounced dorsal ridge, pale red-brown, delicately sculptured; stamens 6-10, free; anthers oval, golden, minute; filaments slender, ca. $3 \mathrm{~mm}$ long, pale; perianth of 2 free whorls of 5 ; petals 5 (rarely fewer), white, bifid, 2.3-5.8 (6.5) $\mathrm{mm}$ long, equaling or exceeding the sepals; sepals 5, 2.8-5.6 (7) $\mathrm{mm}$ long, ovate with acute tips (rarely notched), pale, glossy green with hyaline margins, glabrous, entire; pedicels very slender, ascending, even in fruit somewhat grooved and twisted, glossy, glabrous, elongating from less than a $\mathrm{mm}$ in bud up $104 \mathrm{~cm}$ in maturity; inflorescences few-flowered cymes, terminal and at the tips of upper lateral branches, the axes and pedicels ascending (not divaricate); bracts scarious, lanceolate, mostly 1-5 mm long; leaves leathery, $1-5$ (9) $\mathrm{cm}$ long, $2-12 \mathrm{~mm}$ broad, lanceolate with acute to acuminate tips, the bases clasping, bluish green to dark green with a glossy sheen and glaucousness with a purplish tinge, margins very smooth often swollen into a rim, the cells often hyaline (never papillose); petioles absent; stipules absent; stems lax at base, trailing, then ascending at tips, glabrous, glaucous, grooved and channeled, up to 25 (40) 
$\mathrm{cm}$ long, sometimes reddish toward the bases where they connect to a tough, branching rhizome system; root system fibrous, largely adventitious at nodes of the rhizomes $(2 \mathrm{n}=52,78,104)$.

Infraspecific Variation: This taxon has been subdivided into three species Europe. Plants with ciliate sepals and darker capsules have been called $S$. ciliatisepala Trautv., while short plants with more ovate-lanceolate leaves and dense vegetative shoots in the upper axils are called $S$. crassipes Hultén. New York materials sometimes show these characteristics, but they do not segregate in a way that warrants recognition of specific or even infraspecific taxa. Biosystematic studies of North American S. longipes (Chinnappa and Morton, 1991, for summary) show a highly polymorphic, phenotypically plastic species with one rare Canadian taxon [var. arenicola (Raup) Chinnappa \& Morton] deserving recognition at the infraspecific level.

Importance: Stellaria longipes is reported to be a forage species for reindeer in Greenland.

\section{PETRORHAGIA}

Common Names: Childing-pink, Saxifrage-pink

Authority: (Ser. in DC.) Link, Handb. vol. 2, p. 235, 1831

A genus of 25-30 species of herbs with native distributions primarily in the eastern Mediterranean region. Most species have been treated in 20th century manuals under Tunica or Dianthus, and there has been dispute about the appropriateness of using the generic name Kohlrauschia to represent all or part of the group. Some species are cultivated in gardens, and four have escaped and become naturalized in North America.

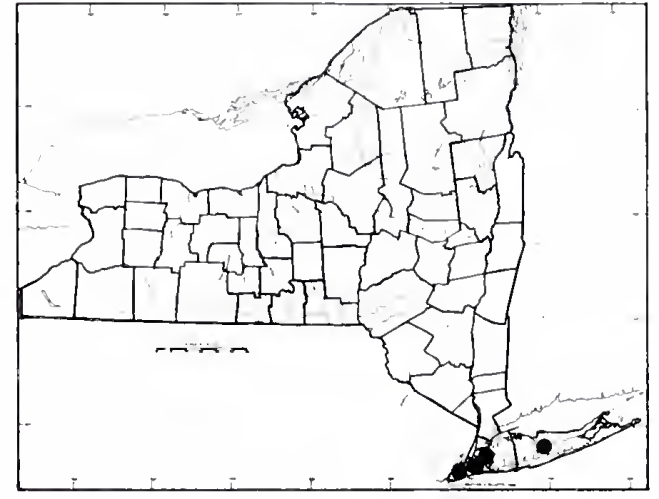

1. Petrorhagia prolifera (L.) Ball \& Heyw. Common Names: Childing Pink

Type Description: Linnacus, Species Pl. I, p. 410, 1753

Synonyms: Dianthus carolinianus, sensu Torr. \&. Gray, not Walt., D. diminutus L., D. prolifer L., Kohlrauschia prolifera (L.) Kunth, Gypsophila prolifera (L.) Arcang., P. prolifer of authors, Tunica prolifera (L.) Scop.

Origin: Native to central and southern Europe and northwestern Africa

Habitats: Dry roadsides and sandy fields

Iabit: Erect-ascending, annual herbs

Flowering: May-October

Fruiting: June-December

General IDistribution: Scattered and locally adven-tive: southern New York, western Michigan, Pennsylvania westward to Kentucky and Oklahoma (California), south to North (South)
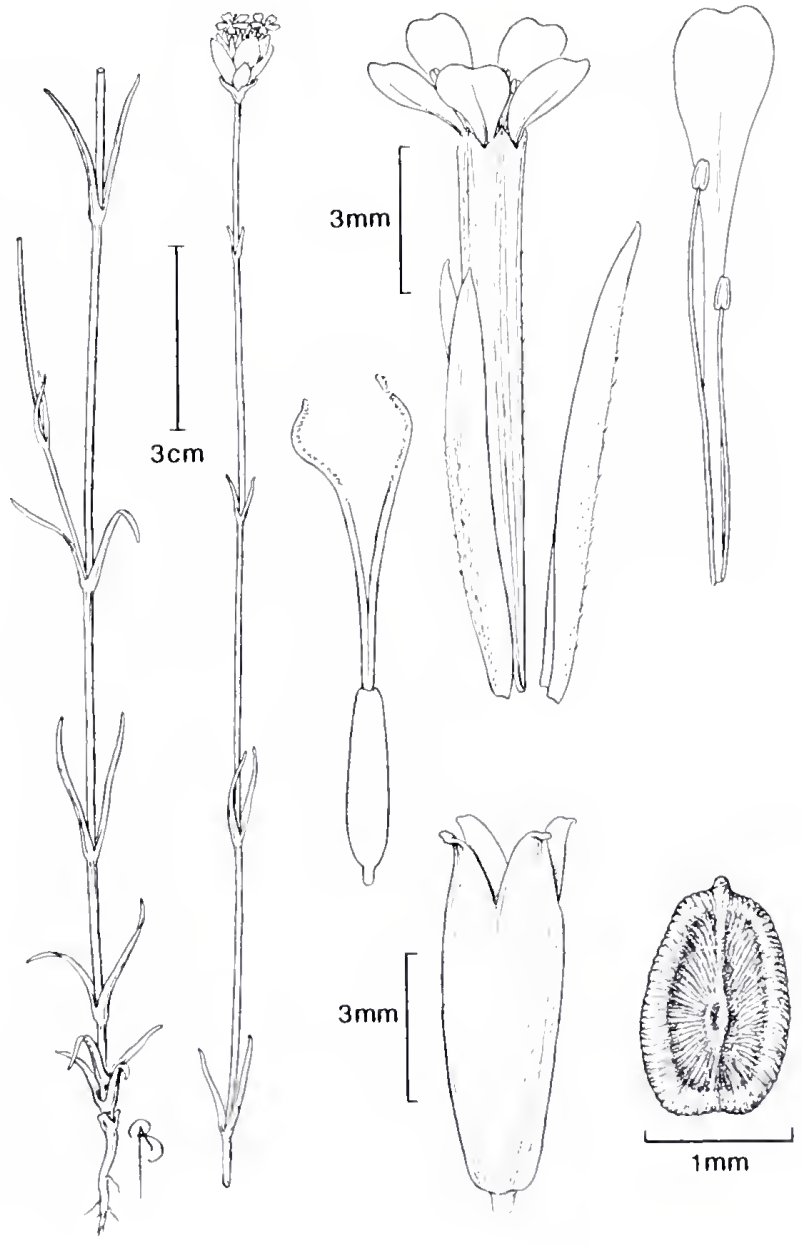
Carolina, northern Georgia and Alabama (Louisiana)

Description: Plants with bisexual flowers; stigmas 2, marginal; styles 2, linear, ca. $5 \mathrm{~mm}$ long; ovary 1, superior, ovoid ca. $1.5 \mathrm{~mm}$ long, $1 \mathrm{~mm}$ broad; fruit a slender, oblong to cylindric capsule, tan, smooth, $4-8 \mathrm{~mm}$ long, 3-5 mm broad, dehiscing by 4 blunt (or slightly bifid) valves; seeds many, oval, 1.1-1.8 mm long, compressed dorsiventrally with an apical tooth and facial hilum, dark brown, the ventral surface papillate, with the appearance of snake skin, finely ridged and fluted dorsally; stamens 10; anthers elongate, pink or bluish; filaments linear, up to $15 \mathrm{~mm}$ long; perianth of 2 whorls, subtended by imbricate bracts (an epicalyx); petals 5 , with 1 prominent concolorous central vein, deep or pale pink to bluish (or nearly white), claws 6-12 (14) $\mathrm{mm}$ long, limbs flared, 3-5 mm long, obovate to obdeltoid, broadly truncate or emarginate at tips, lacking dark basal coloration; sepals fused into a minutely pubescent tube, 6-10 (13) $\mathrm{mm}$ long with 5 short, acute calyx lobes, the slender tube greenish with scarious commissures between the veins; pedicels lacking; inflorescence a terminal, capitate, globose to ovoid head, bearing 2-7 (11) flowers (or flowers solitary); flowers often blooming one at a time, sessile within an involucre $4-14 \mathrm{~mm}$ long, up to $22 \mathrm{~cm}$ broad; flowers subtended by lanceolate bracts 4-7 $\mathrm{mm}$ long and 1-2 $\mathrm{mm}$ broad, the outer involucral bracts broadly to narrowly ovate or obovate, up to $13 \mathrm{~mm}$ long, $6 \mathrm{~mm}$ broad, the tips obtuse (or mucronate on the outermost bracts), greenish, becoming leathery, stramineous to brown with age; peduncle of the inflorescence 2-30 (50) $\mathrm{mm}$ long, flexuous, glabrous, ribbed; leaves paired, connate at base [sheath 1-2 (-4) $\mathrm{mm}$ long], linear to narrowly oblanceolate, 5-25 (40) $\mathrm{mm}$ long, 2-4 mm broad, usually 3-veined, the midrib sometimes puberulent, margins variously notched and scabrous; petioles absent; stipules absent; stems solitary, sparsely branched or much branched at base, erect, glabrous to scabrescent, up to $60 \mathrm{~cm}$ tall, from a fibrous, annual root system, often with a welldeveloped, erect taproot $(2 \mathrm{n}=30)$.

Infraspecific Variation: The plants vary in size, ranging from slender, dwarf individuals with small, few-flowered heads to robust plants 5-6 decimeters tall with 8-10 large basal branches and flowering heads up to $2 \mathrm{~cm}$ broad. Plants varying in leaf margin texture and pubescence have been named, but these do not seem to warrant taxonomic rank. Large and small-flowered variants are also questionably distinct (see: Rabeler, 1985; Thomas \& Murray, 1981, Thomas 1983), and may represent morphological manifestations linked with the incompletely understood breeding system.

Importance: The larger-flowered race is occasionally cultivated. The flowers are sometimes used to make a tea in Europe, and the extract was used in folk medicine prior to the 17th Century, but the species was often dropped from later herbals.

Note: Petrorhagia saxifraga (L..) Ser. ex Link, the saxifrage-pink, is more frequently cultivated than the above species, but it has rarely been reported in New York State as a nonpersistent garden escape. It is a perennial herb that bears solitary flowers (or clusters of 2-3), as opposed to the capitate heads of $P$. prolifera.

\section{DIANTHUS}

Common Names: Pink, Childing Pink, Sweet-William

Authority: Linnaeus, Species Pl. 1, p. 409, 1753

A genus of up to 300 species, depending upon interpretation of taxa at both the generic and specific levels. Dianthus species are widely distributed in Eurasia and North Africa, where they usually grow in sunny habitats. The single, native New World species is $D$. repens Willd. of Alaska. Certain species, especially those called "pinks" and "sweet-Williams," are popular in cultivation worldwide. A famous cultivar among Dianthus species is $D$. caryophyllus $\mathrm{L}$., the carnation of horticulture. Large-flowered, multi-petaled variants of this plant abound in the commercial cut-flower and pot-plant trade. Dianthus $\mathrm{x}$ allwoodii Hort., is an equally well-known and widely cultivated hybrid of $D$. caryophyllus and $D$. plumarius. There are over 27,000 registered cultivars of Dianthus worldwide.

Description: Plants with bisexual flowers or polygamous, showing some male-sterility; stigmas 2; styles 2, free or united below; ovary 1, superior; ovules many, borne on a free-central placenta; fruit a unilocular capsule dehiscing by 4 (5) valves, often borne on a carpophore; seeds many, flattened or disk shaped; embryo scarcely curved; perisperm nuclear; stamens 10; filaments linear; anthers often colored like the perianth; perianth of 2 whorls subtended by bracts; petals 5 (to many in cultivars), clawed, the limb entire or dentate to fimbriate 
or laciniate, but not deeply bifid, sometimes bicolored; sepals 5, united into a cylindric calyx tube with $30+$ nerves, lacking scarious commissures; bracts directly subtending the calyx tube in 1-3 imbricate pairs (an epicalyx); pedicels slender to fleshy; inflorescences panicles or cymes, with flowers in fascicles, glomerate heads, or borne solitary at branch tips; leaves paired, entire connate at base, at the conspicuously to only slightly swollen nodes, linear to broad; petioles absent; stipules absent; stems herbaceous to woody, especially near the base; root systems perennial (rarely annual or biennial).

\section{KEY TO SPECIES}

1. Cauline leaves often more than $1 \mathrm{~cm}$ wide, broadly lanceolate; inflorescences dense, showy, corymb-like

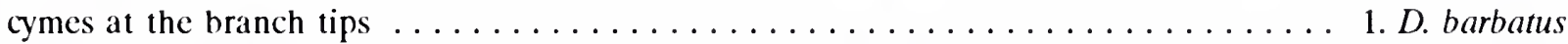

1. Cauline leaves linear to narrowly lanceolate or oblanceolate, less than $1 \mathrm{~cm}$ wide; inflorescences of scattered fascicles, open cymes or panicles (or flowers solitary) . . . . . . . . . . . . . . . . (2)

2. Flowers subsessile, clustered in dense fascicles; epicalyx bracts equalling the calyx tube (or nearly so);

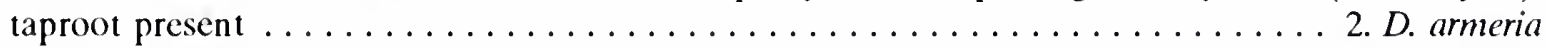
2. Flowers pedicelled, in open inflorescences or solitary; epicalyx bracts less than half the length of the calyx; roots largely adventitious on rhizomes or stolons $\ldots \ldots \ldots \ldots \ldots \ldots \ldots \ldots \ldots$ (3)

3. Petal margins ragged-fimbriate, long-fringed; inflorescence few-flowered; stem often solitary from dense,

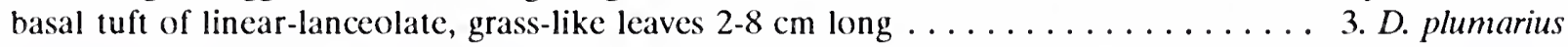

3. Petal margins merely dentate; inflorescences of ten many-flowered and borne on multiple stems from muchbranched, matted bases; basal leaves oblanceolate, mostly less than $1.5 \mathrm{~cm}$ long . . . . . .

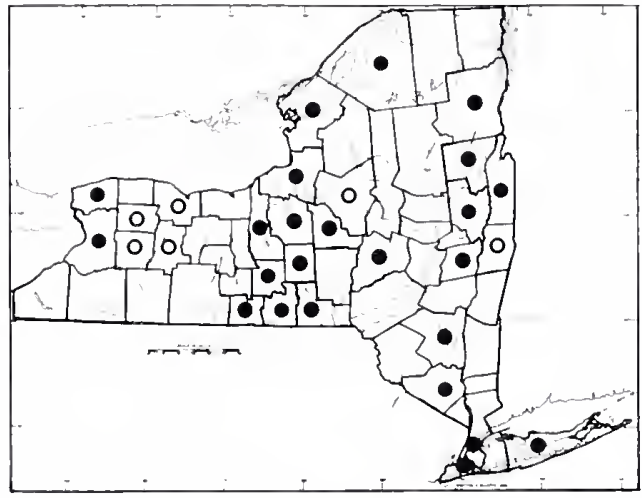

1. Dianthus barbatus L.

Common Names: Sweet William, Bunch-pink, Sweet-johns, Bloomy-pink, London-pride, French Pink, Snowflake

Type Description: Linnacus, Species PI. I., p. 409, 1753

Origin: A native of southern Europe

Ilabitats: Roadsides, cultivated ground, waste places, meadows, woodland clearings and fields, in full sun to partial shade

IIabit: Tufted, erect, perennial herbs (sometimes annual or biennial in cultivation)

Flowering: June-September

Fruiting: July-October

General Distribution: Widely escaped and naturalized in Eurasia, and in North America from Quebec to British Columbia south to California, the Carolinas, Louisiana and Texas

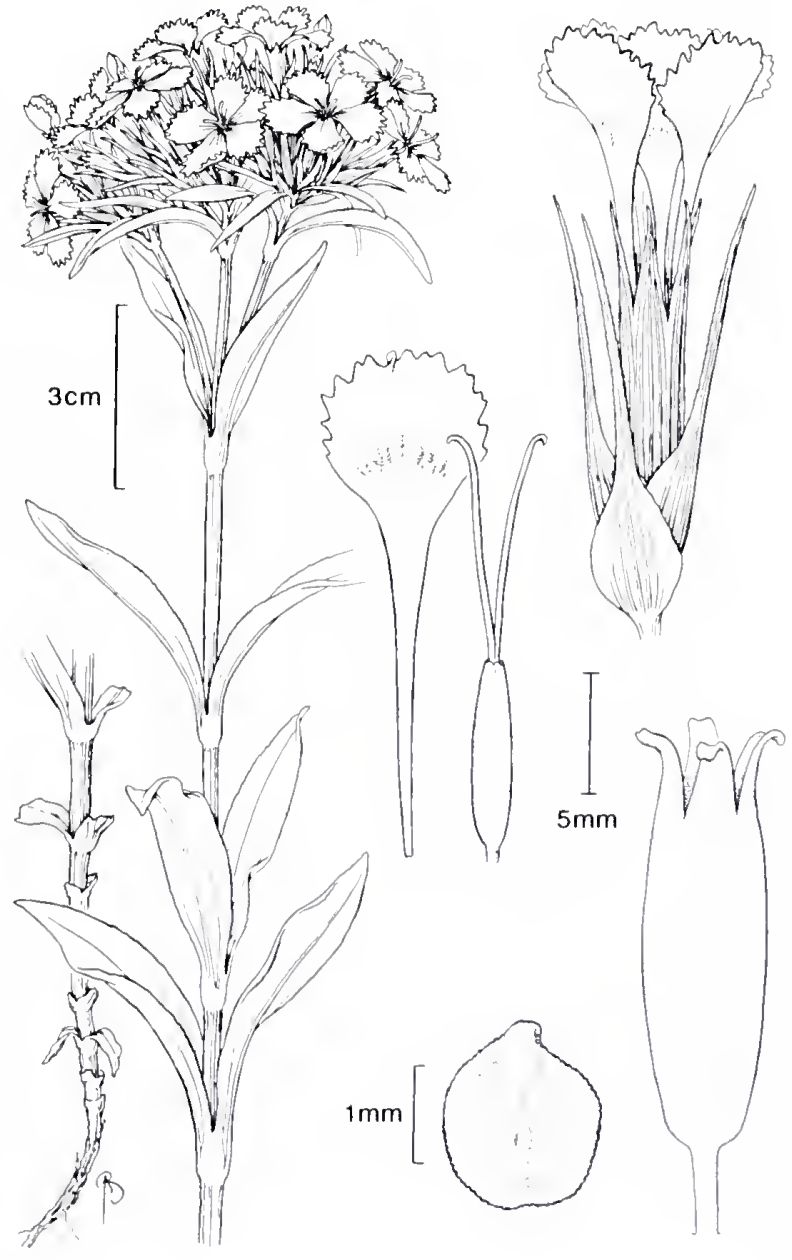


Description: Plants with bisexual flowers; stigmas marginal, linear, glandular lines extending to near the style bases; styles 2, filamentous, pale, 8-12 mm long; ovary elliptic, smooth, ca. $3 \mathrm{~mm}$ long, on a short gynophore; fruit a cylindric capsule, tan, glabrous, 9-12 (15) $\mathrm{mm}$ long, 4-5 $\mathrm{mm}$ broad, opening by 4 acute (but minutely blunt-tipped) valves, borne on a carpophore up to $4 \mathrm{~mm}$ long; seeds many, smooth, brown, 2-3 $\mathrm{mm}$ long, apiculate, ovoid-deltoid in outline and dorsally flattened; stamens 10 ; anthers ca. $1.5 \mathrm{~mm}$ long, slender, dorsifixed; filaments pale, filamentous, $9-16 \mathrm{~mm}$, varying in length within the same flower; perianth of 2 whorls subtended by an epicalyx of imbricate bracts; petals distinctly divided into claw and limb, the claw within the calyx tube, pale, linear, 8-14 (17) $\mathrm{mm}$ long, ca. $0.5 \mathrm{~mm}$ broad, expanded abruptly at the mouth of the calyx into a showy limb, ovate-spatulate to reniform, 7-10 (17) $\mathrm{mm}$ broad, the outer margin shallowly and irregularly dentate (bearded), (limb) purple, roseate, pink, white or bicolored, the paler color either interior or exterior to the darker (giving the flower a bull's-eye appearance); sepals 5, the lobes pale greenish, sharply attenuate to aristate, 3-6 (9) $\mathrm{mm}$ long, united into a cylindric to slightly inflated tube below, 9-20 mm long, 3-8 $\mathrm{mm}$ broad, the tube glabrous, shiny, pale green with 30-40+ strong, parallel veins; epicalyx bracts up to $2 \mathrm{~cm}$. long, ovate at base with long aristate tips, shorter than the flowers to equaling or slightly surpassing them, greenish or purplish with parallel veins and ciliate to scabrescent margins; pedicels 0-7 (11) mm long, ensheathed in the bases of epicalyx bracts; peduncles glabrous, bearing the inflorescence fascicles in close proximity; inflorescence a showy, corymb-like cyme of densely crowded fascicles of flowers; the primary bracts subtending the inflorescence linear-lanceolate, green, glabrous $2-5 \mathrm{~cm}$ long, $2-4 \mathrm{~mm}$ broad, sheathing at base with ciliate margins; leaves broadly lanceolate to oblanceolate, 2.5-7.5 (11) cm long, (0.5) 1-2 (2.4) cm broad, entire, tips acute, surfaces glabrous, scabrescent along the veins and margins, ciliate on the margins of the sheathing bases that may be acute to attenuated, simulating petioles; stipules absent; stems greenish, often somewhat glaucous, ribbed, glabrous, stout near the base (up to $1 \mathrm{~cm}$ thick), erect or ascending up to $50(70) \mathrm{cm}$, the nodes only slightly swollen; plants tufted and spreading by stolons and rhizomes; root system fibrous, largely adventitious from the branching, perennial bases $(2 \mathrm{n}=30,90)$.

Infraspecific Variation: European authors have recognized D. barbatus ssp. compactus (Kit.) Stoj., distinguishing it on the basis of a reddish epicalyx shorter than the flowers and highly attenuated leaf bases. In Europe, flower color is said to be purple, but, in our naturalized plants, flowers often are rosy or white. Other cultivars reported as escapes in New York State include dwarfs and bicolored variants. In the cultivar 'Auriculiflorus' the bases of the petal limbs are auricled.

Importance: A showy garden plant, cultivated around the world in boreal, cool-temperate and Mediterranean climates. 


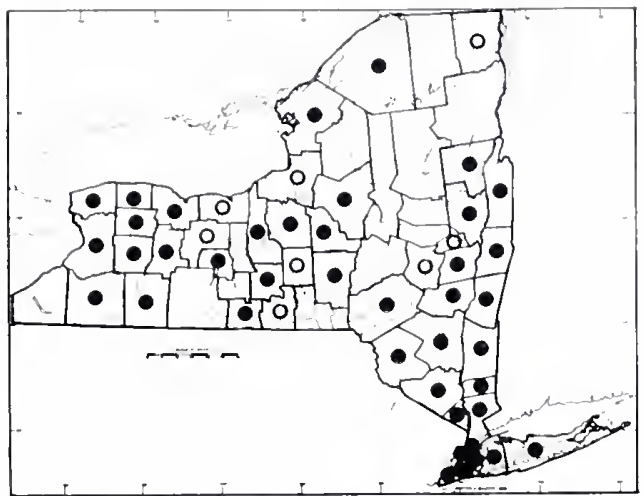

\section{Dianthus armeria $\mathrm{L}$.}

Common Names: Deptford Pink, Grass-pink

Type Description: Linnacus, Species PI. I, p. 410, 1753

Synonyms: $D$. armeriastrum Wolfner, D. epirotus Halácsy

Origin: Native to temperate and Mediterranean Europe and North Africa

IIabitats: Sandy banks, roadsides, fields, dunes and dry soils of waste places and urban environments

Iabit: Slender, erect, branching, annual, biennial or weakly perennial herbs

Flowering: June-August

Fruiting: June-September

General Distribution: Widely naturalized: Quebec to British Columbia, south to California and southeast to Georgia

Description: Plants with bisexual flowers; stigmas marginal, glandular lines extending to near the

style bases; styles 2, filamentous, 6-9 mm long, exserted from the perianth; ovary 1, cylindric, 4-5 mm long, borne on a short gynophore; fruit a cylindric capsule 11-16 mm long 2-3 mm broad, smooth, stramineous, opening by $4-5$ narrow, terminal valves and borne on a carpophore 1-2 mm long; seeds many, 1.1-1.5 mm long, 0.7-0.9 mm broad, apiculate, elliptic, flattened on one side, dark brown, with muricate surfaces; stamens 10; anthers elongate, dorsifixed, golden or pinkish; filaments slender, $8-12 \mathrm{~mm}$ long; perianth of 2 whorls subtended by an epicalyx; petals 5, distinctly clawed, the claw within the calyx tube very slender, pale, 10-18 $\mathrm{mm}$ long, limb ca. $5 \mathrm{~mm}$ long, $3 \mathrm{~mm}$ broad, usually shallowly dentate with $2-5$ teeth, deep rose to pale pink speckled with white (rarely all white); sepals 5, the limbs sharply attenuate with hyaline margins, 3-7 $\mathrm{mm}$ long, united below into a slightly inflated, cylindric tube $14-21 \mathrm{~mm}$ long, $3-4 \mathrm{~mm}$ broad, with $30+$ strong ribs, greenish, rosy tinged and mottled, densely minutely villous to almost glabrous; epicalyx bracts greenish to red tinged, sometimes with hyaline margins, strongly ribbed, lanceolate to basally expanded and aristate, usually hispid, (5-) 15-21 mm long, sometimes equalling the calyx; pedicels $0-6 \mathrm{~mm}$ long, ensheathed in bract bases; inflorescences densely clustered obconic fascicles, borne terminally and on the upper lateral branches when present (flower rarely solitary with one epicalyx bract and 2-4 primary bracts); primary inflorescence bracts lanceolate, often equaling and sometimes surpassing the inflorescence length, up to $3.3 \mathrm{~cm} l o n g, 4 \mathrm{~mm}$ broad at base, strongly veined, hispidulous, at least along the margins; leaves usually 4-6 pairs per stem, linear to narrowly lanceolate, $1-7$ (9) cm long, $0.5-6.5 \mathrm{~mm}$ broad, glabrescent to densely short-scabrous, especially along the strong central vein and margins, clasping at base, tips acute to acuminate (or abruptly blunted); petioles 
absent; stipules absent; stems erect, up to $90 \mathrm{~cm}$ tall, simple or branched upward, slender to stiff and somewhat stout at base, nearly glabrous to scabrescent at the swollen nodes; root system usually a biennial taproot with well-developed lateral roots or weakly annual under severe habitat conditions $(2 \mathrm{n}=30)$.

Infraspecific Variation: Plants may be robust biennials, annuals or weak perennials, with apparent plasticity in response to soil and microclimatic conditions. The number of inflorescences and lateral branches can also vary strikingly within the same population. Flower color varies in intensity, and white-flowered plants are known in some wild populations.

Importance: These plants are prolific when cultivated in dry, sandy or rocky gardens, and they escape to similar habitats in eastern North America.

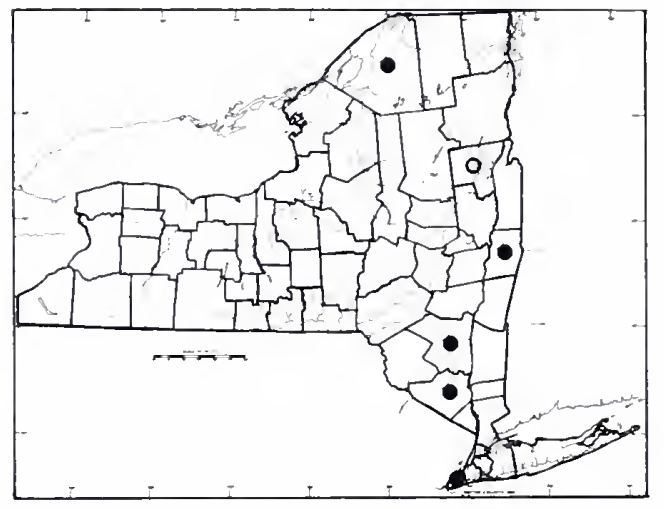

3. Dianthus plumarius L.

Common Names: Garden Pink, Grass-pink, Cottage Pink

Type Description: Linnaeus, Species P1. I, p. 411, 1753

Synonyms: $D$. blandus (Reichenb.) Hayek, $D$. hoppei Portenschl., D. hungaricus Pers., D. lumnitzeri Weisb., D. praecox Kit. ex Willd.

Origin: A native of montane, eastern Europe

Habitats: Grassy banks, sandy roadsides, open, rocky woodlands and clearings (lime tolerant)

Iabit: Tufted, rhizomatous perennials with erect flowering stems

Flowering: June-August

Fruiting: June-October

General Distribution: Scattered naturalized populations from occasional garden escapes: Nova Scotia; New England, New York, west to Michigan, Minnesota, Missouri, rarely south to Ala-
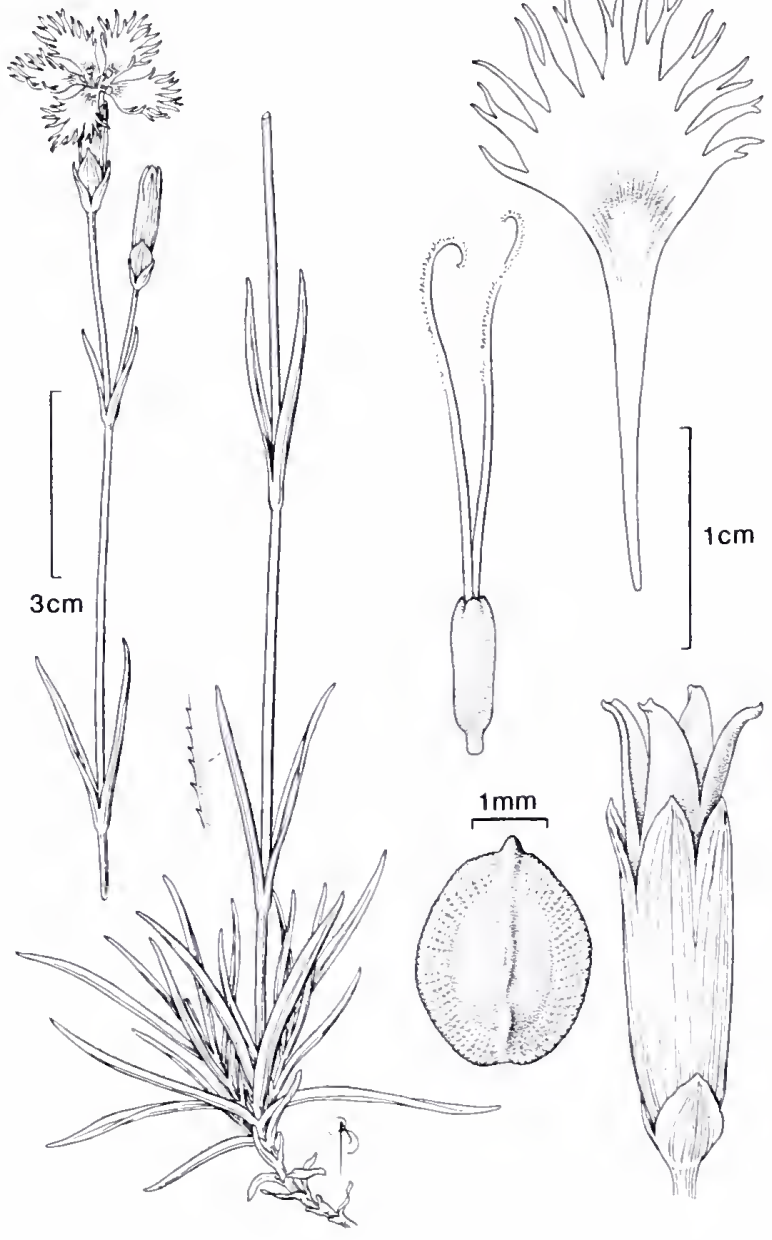
bama (North Carolina)

Description: Plants with bisexual flowers; stigmas marginal, glandular-puberulent lines; style 2, sometimes fused near base, linear, 13-21 mm long; ovary ovoid-cylindric, 6-8 $\mathrm{mm}$ long, borne on a gynophore; fruit a cylindric capsule equaling or exserted from the calyx, 1.6-2.6 (3.2) $\mathrm{cm}$ long, $4-7 \mathrm{~mm}$ broad, smooth, tan, opening by 4 broadly acute to obtuse (minutely blunt-tipped) teeth, borne on a carpophore up to $5 \mathrm{~mm}$ long; seeds many, ovate-elliptic,, flat on one side, ca. $1.5 \mathrm{~mm}$ long brown, muricate; stamens 10; anthers oblong, dorsifixed; filaments linear, up to $22(30) \mathrm{mm}$ long; perianth of 2 whorls subtended by an epicalyx; petals distinctly clawed, the claws 12-23 (30) $\mathrm{mm}$ long, linear, petal limbs 11-18 mm long (including fringe), 6-13 mm broad, obdeltoid, the outer margin fimbriate-lacerate, the ragged fringe $1 / 3$ to $1 / 2$ the limb length, usually white, red-striated below or deep pink to reddish at the limb bases; sepals 5, lobes 3-7 mm long, 1-2 mm broad, obtuse-apiculate, smooth, greenish or pink-tinged with reddish or purplish fringed margins that may be somewhat membranaceous just below the slightly cucullate tip, calyx tube 12-22 (31) mm long, 3-5 mm 
broad, glabrous, $40+$ ribbed, greeenish, often rosy to purplish-tinged; epicalyx bracts $2-6$, in pairs that are slightly connate at base, $3-9 \mathrm{~mm}$ long, $2-6 \mathrm{~mm}$ broad, cucullate-ovate with apiculate tips, pale greenish, ribbed, with reddish (purplish), somewhat membranaceous margins; pedicels $3-40 \mathrm{~mm}$ long, grooved, smooth; inflorescence of 2-3 (5) flowers, borne in the upper leaf axils, or flower terminal, solitary; cauline leaves linear, (1) 2-6 (8) cm long, 1-2 $\mathrm{mm}$ broad, with a strong midrib and parallel veins, glabrous, greenish to glaucous, somewhat membranaceous near the ciliate to scabrescent margins, tips acute to acuminate, bases, scarious, connate; basal leaves densely tufted (grass-like), some pairs remaining short (4-9 $\mathrm{mm}$ long and bract-like within the (uft), but most basal leaves linear to linear-lanceolate, 2-8 (12) cm long, 1-2 (3) mm broad, usually with a strong midrib and pseudoparallel veins, margins scabrescent, tips acuminate to subacute, surfaces smooth, green to glaucous, scarious at the connate bases; petioles absent; stipules absent; stems usually solitary, unbranched, from basal tufts of leaves, fluted and ribbed above, $15-30$ (45) cm tall; rhizomes wiry, dark brown with crowded nodes and scale-like disintegrating leaf bases, $2-4 \mathrm{~mm}$ broad, and may be short or up to 4-12 cm long between tufted green shoots, horizontal, but arched upward into a caudex just below the tuft; root system fibrous, adventitious $(2 \mathrm{n}=30,60,90)$.

Infraspecific Variation: A number of cultivated variants have received varietal or horticultural names. These include color forms ranging from rosy to purple and variously bicolored flowers; there are also double-flowered plants with dark green leaves, and a variant with attenuated calyces.

Importance: These plants occurs in the wild as sporadically naturalized escapes from cultivation; they are relatively popular garden plants, known to grow in dry, limy places.

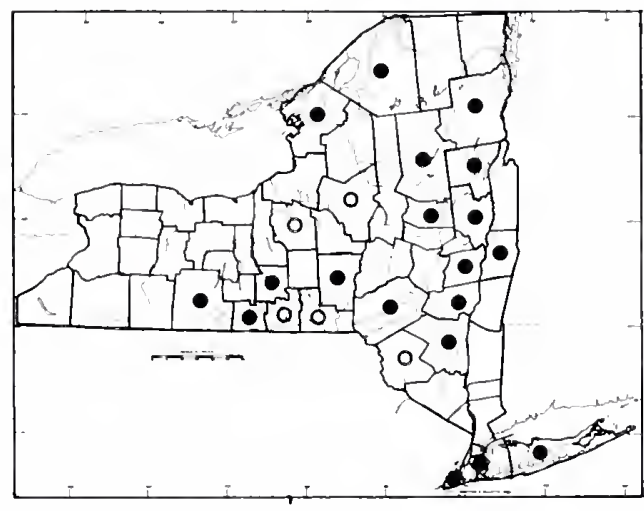

\section{Dianthus deltoides I.}

Common Names: Maiden-pink, Meadow-pink

Type Iescription: Linnacus, Species Pl. I, p. 411, 1753

Origin: Native to Northern Europe

Iabitats: Dry open places, roadsides, sparse woodlands, vacant lots, meadows, stream banks (lime tolerant)

Ilabit: Spreading, sometimes matted, rhizomatous perennials with ascending to erect flowering shoots

Flowering: June-August

Fruiting: Late June-October

General Distribution: Naturalized from Quebec to Minnesota, Illinois, Virginia, North Carolina and Arkansas; also escaping in Montana and Washington state and probably in other northtemperate regions

Description: Plants with bisexual flowers; stigmas marginal glandular lines extending almost to the style bases; styles 2, filamentous, 5-7 mm long; ovary cylindric, 4-5 mm long, borne on a short gynophore; fruit a cylindric 
capsule, 14-18 mm long, ca. $2 \mathrm{~mm}$ broad, glossy, greenish to tan, opening by 4 (5) narrow, blunt-tipped valves, borne on a carpophore ca. $3 \mathrm{~mm}$ long; seeds many oval, apiculate, flattened on one side, ca. $1.1 \mathrm{~mm}$ long, 0.8 $\mathrm{mm}$ broad the surfaces muricate, dark brown to black; stamens 10; anthers oblong, basifixed; filaments slender, $13-18 \mathrm{~mm}$ long; perianth of 2 whorls subtended by an epicalyx; petals 5 , distinctly divided into claw and limb, the claw 10-19 mm long, pale, slender, but not linear, gradually broader (often more pigmented) toward the apex, the limb deltoid, 5-12 $\mathrm{mm}$ long, $4-9 \mathrm{~mm}$ broad, the margin shallowly to prominently dentate, usually with 4-7 teeth, deep rose to pink (white spotted) or white, flowers sometimes prominently bicolored with dark purple-rose or white centers and distinct rosy margins; sepals 5, the lobes $2-4 \mathrm{~mm}$ long, acute, puberulent with ciliate margins, the tube cylindric, 11-15 (18) mm long with 30+ moderately prominent ribs, greenish with pink or deep rosy tint, the surface puberulent; epicalyx bracts $2(-4)$, pale, pink-tinged, ovate with sharply acuminate to slightly aristate tips, $5-7 \mathrm{~mm}$ long, $2-4 \mathrm{~mm}$ broad; pedicels $(0.4) 1-3(4.7) \mathrm{cm}$ long, scabrescent; inflorescence an open, cyme-like panicle, often bearing many flowers on erect, fertile branches, the flowers single on distinct pedicels, but not fascicled; bracts at the pedicel bases leaf-like but more membranous, linear, ca. $1 \mathrm{~cm}$ long, puberulent; leaves dimorphic, those of the creeping vegetative shoots and bases of flowering shoots oblanceolate to spatulate, 2-13 (16) $\mathrm{mm}$ long, $0.5-3.2 \mathrm{~mm}$ broad, their margins scabrescent, tips obtuse to subacute, cauline leaves of flowering shoots in 4-10 pairs, linear to lanceolate, acute-tipped, 5-30 (38) mm long, 0.3-3.5 $\mathrm{mm}$ broad, the strong midrib and margins scabrescent, surfaces somewhat mealy-glaucous, bases shallowly clasping with hyaline, ciliate margins; petioles absent; stipules absent; stems dimorphic, the vegetative branches crowded, wiry, much-branched, creeping to low-bushy; flowering branches erect or ascending, up to $40(60) \mathrm{cm}$ tall, slender, rarely branched except in the inflorescence, internodes smooth to papillate or scabrescent, nodes not conspicuously swollen; rhizomes and stolons much-branched, forming wiry clumps; root system largely adventitious from the perennial bases $(2 n=30)$.

Infraspecific Variation: Flower color is extremely variable in escaped cultivars, ranging from deep purple-rose to pink or white, often in bicolored combinations.

Importance: These plants are widely cultivated in gardens. 


\section{AGROSTEMMA}

Common Name: Corn Cockle

Authority: Linnaeus, Species Pl. 1, p. 435, 1753

A genus of 2-3 species (or monotypic with varieties and races), native to eastern Europe and Asia Minor. The plants are closely related to Lychnis but annual. The naturalized representative in North America, $A$. githago L., is a weed of corn and other grain fields, also widespread in Eurasia, where it is an agricultural pest as well.

The seeds are poisonous.

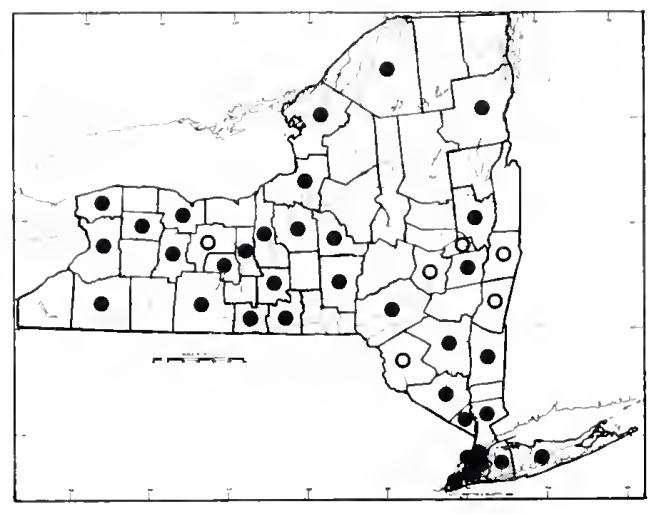

1. Agrostemma githago L.

Common Names: Corn Cockle, Purple Cockle, Corn-rose, Corn Campion

Type Description: Linnaeus, Species Pl. I., p. 435, 1753

Synonyms: Lychnis githago (L.) Scop.

Origin: Native to Mediterranean Europe

IIabitats: Corn and wheat fields and other cultivated ground, roadsides pastures and waste places

IIabit: Stout, branching, erect or spreading annuals

Flowering: Late May-September

Fruiting: June-November

General Distribution: Newfoundland to Alaska, south to California, eastern Texas and northern Florida

Description: Plants with bisexual flowers; stigmas linear glandular lines to near the style bases; styles (4) 5, linear, 1.0-1.8 (2.1) cm long; ovary 1, ovoid, subsessile; fruit a stout, ovoid capsule, becoming somewhat woody, smooth and golden on dehiscence by (4) 5 acute (minutely blunted) valves, (the capsule) 14-18 (21) mm long, 8-14 mm broad, subsessile (carpophore absent), enclosed within, and slightly exserted from, the inflated calyx tube; seeds many, 2.9-3.4 mm long, ca. $2 \mathrm{~mm}$ broad, plump, roughly triangular with 2 flattened sides, dark brown to purple-black, surfaces with prominent, acute tubercles; stamens 10; anthers linear, basifixed; filaments slender, $9-20 \mathrm{~mm}$ long; perianth of 2 whorls; petals 5 , showy, the claw creamy to pale pinkish or purplish, 10-14 $\mathrm{mm}$ long, $2-3 \mathrm{~mm}$ broad, limb bright rose-red to purple, paler toward the base (or white), 10-20 (26) $\mathrm{mm}$ long, 7-15 (18) mm broad, the margin retuse, sometimes shallowly dentate to almost entire, limb base without auricles or other appendages; sepals 5, the lobes strongly ascending and exceeding the petals, lanceolate, (11) $18-32$ (41) $\mathrm{mm}$ long, $1.5-3.6 \mathrm{~mm}$ broad, with subacute to acuminate tips, strigose to silky-sericeous, the pale trichomes with swollen bases; calyx tube cylindric, somewhat inflated in flower, ovoid and strongly inflated in fruit, enclosing the capsule except at the slightly exserted tip, 11-17 (19) $\mathrm{mm}$ long, up to $15 \mathrm{~mm}$ broad, with $10(9-12)$ broad, greenish veins with sunken, pale, scarious, herbaceous 
commisures between, silky strigose to pale hispid throughout; peduncles 3-15 (26) cm, stout, flexuous, silky; inflorescence of singly borne flowers on long peduncles in the upper leaf axils; leaves opposite, entire, shallowly connate at base, linear to lanceolate, mostly $6-12 \mathrm{~cm}$ long, $2-5 \mathrm{~mm}$ broad, silky, appressed strigose to sericeous (or hispid) the trichomes with swollen bases; petioles absent; stipules absent; stems stiff, up to $1 \mathrm{~cm}$ in diameter, terete to grooved, erect-ascending up to 1 (1.2) $\mathrm{m}$ tall, long-strigose to sericeous; root system a tough, annual taproot up to $15 \mathrm{~cm}$ long with strong lateral branches and fibrous rootlets $(2 \mathrm{n}=48)$.

Infraspecific Variation: Flower color varies from purple to rose-pink and white. In the cultivar 'Milas' the flowers are rose-purple and up to $5 \mathrm{~cm}$ in diameter. Large- and small-seeded races are reported from Europe where selection has gone on in crop fields (see below).

Taxonomic Note: Plants known as $A$. githago L. are known exclusively as weeds of corn and wheat fields and waste places where they have spread around the world. It has been suggested that this species arose from $A$. brachylobum (Fenl) Hammer (A. gracilis Boiss.), a species with a more restricted range in Greece and Turkey. Agrostemma brachylobum differs from $A$. githago in having petals longer than the calyx lobes and black spots at the petal bases. Another closely related taxon, $A$. linicola Terechov, is a weed of flax fields, with an earlier blooming period, green-spotted petals and smaller seeds with less prominent tubercles. These weedy variants may be no more than varieties (Hammer et al., 1982) or races selected under the influence of agricultural practices.

Importance: Corn cockle is found less often as an escape from garden cultivation than as a weed of corn, winter wheat, and rye fields. The seeds are poisonous, containing up to 7 per cent of the sapogenin githagenin. They are especially toxic when ground or chewed, causing gastroenteritis, vomiting, slow breathing, dizziness, diarrhea, stomach pain, lesions and possible death to humans and certain livestock, such as horses, cattle and poultry (less often pigs). The seeds were once found as severe grain crop contaminants that sometimes caused significant danger and profit losses. Modern screening and sorting methods have largely eliminated those risks, but corn cockle seeds may still be found in dangerous quantities in some ground corn and oat meals. The roots of the plant are also suspect in hog poisoning cases.

\section{GYPSOPHILA}

Common Names: Baby's-breath, Gypsophil

Authority: Linnaeus, Species Pl. I, p. 406, 1753

A genus of about 140 species native to Eurasia and North Africa; well represented in the Mediterranean Region. Gypsophila paniculata L. and G. elegans Bieb. are commonly cultivated under the name "baby's-breath," grown in gardens and greenhouses for use in floral arrangements. These and other Gypsophila species are also grown in rock gardens or planted as borders to produce a lacy fringe effect.

Description: Plants with bisexual flowers; stigmas 2 (3); styles 2 (3); ovary 1, superior, not stalked; ovules many, borne on a free, central placenta; fruit a sessile, 1-locular, 4-valved capsule; seeds many, subreniform, flattened, rugose to tuberculate; embryo peripheral with a prominent radicle; perisperm albuminous; stamens 10; filaments slender, free; anthers dorsifixed; perianth of 2 whorls, not subtended by an epicalyx; petals clawed and limbed, lacking coronal scales at the corolla mouth; sepals 5 with hyaline margins, united into a turbinate to campanulate calyx tube with veinless commisures; pedicels slender; bracts many, small; inflorescence paniculate, often ubiquitous, corymbiform; leaves paired, connate-clasping, entire, linear to broadly strap-like; petioles lacking; stipules lacking; stems often much-branched upward; root system woody, perennial, or an annual taproot.

\section{KEY TO SPECIES}

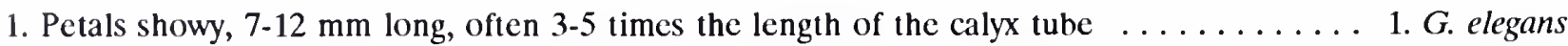

1. Petals usually $6 \mathrm{~mm}$ long or less, equaling to about twice the length of the calyx tube .......... (2)

2. Lower cauline leaves needle-like, usually $10 \mathrm{~mm}$ long, $1 \mathrm{~mm}$ broad or less; stem delicate, capillary, from

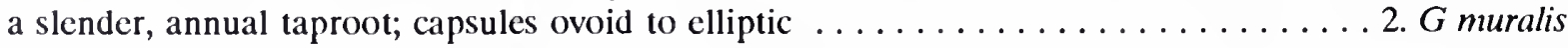

2. Lower cauline leaves lanceolate, often up to $1 \mathrm{~cm}$ broad, $5-8 \mathrm{~cm}$ long; stem slender to stout, from a tough, perennial base; capsules spheroid $\ldots \ldots \ldots \ldots \ldots \ldots \ldots \ldots \ldots \ldots$. . . paniculata 


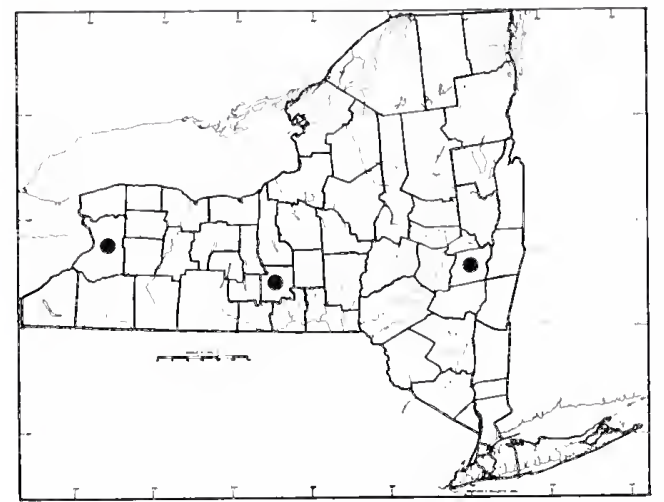

1. Gypsophila elegans Bieb.

Common Names: Baby's-breath, Tall Gypsophil, Annual Baby's-breath

Type Description: Fl. Taur.-Cauc., vol. 1, p. 319, 1808

Synonyms: G. carminea Hort., G. grandiflora var. alba Hort.

Origin: Native to the Caucasus and montane Asia Minor

IIabitats: Roadsides and waste places as an escape

Iabit: Erect or ascending annuals with muchbranched inflorescences

Flowering: May-September

Fruiting: June-November

General Distribution: Occasionally escaping cultivation and becoming naturalized from southern Labrador to Alberta, New York, western Pennsylvania, Virginia and North Carolina

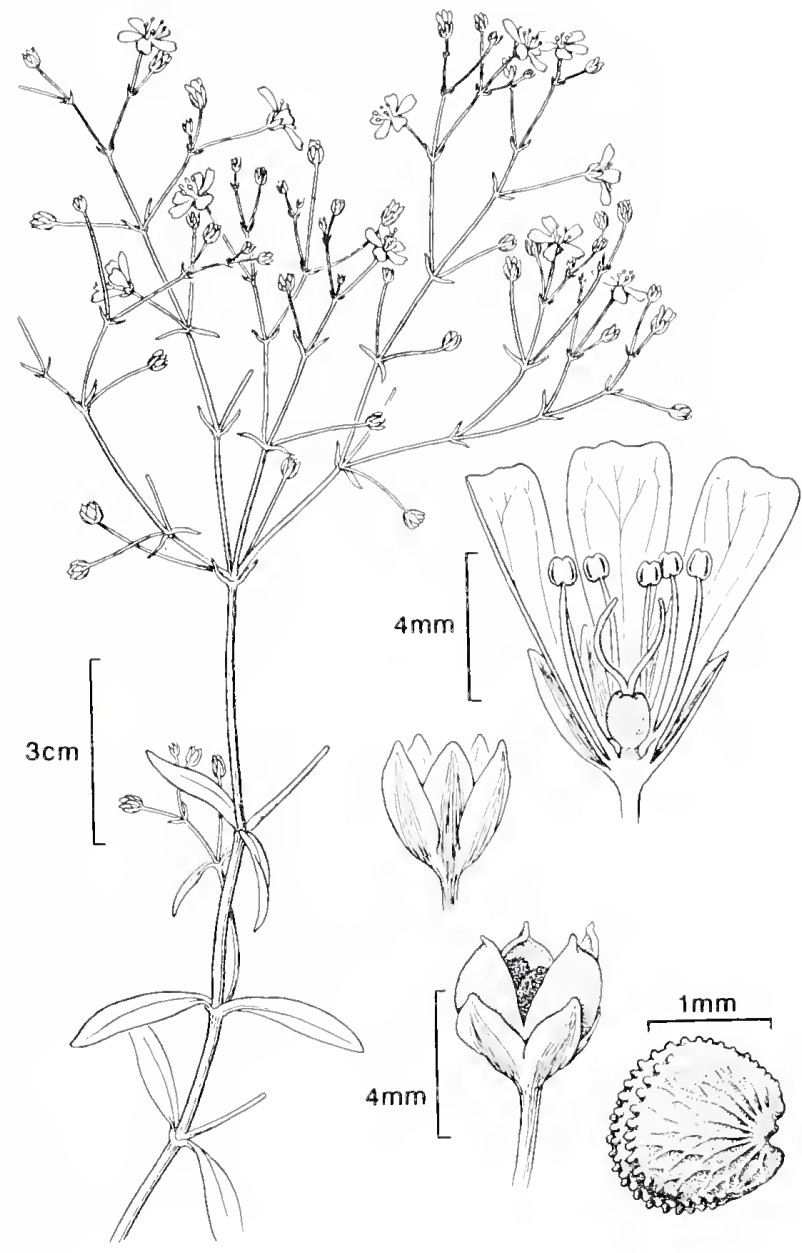

Description: Plants with bisexual flowers; stigmas 2; styles 2, filamentous, ca. $2 \mathrm{~mm}$ long; ovary spheroid, ca. $1 \mathrm{~mm}$ broad; fruit a spheroid capsule, $3-4 \mathrm{~mm}$ in diameter, opening by 4 broad, obtuse to apiculate valves that split to near the base, surface glossy, tan; seeds several, comma-shaped, plump, 1.4-1.6 mm in diameter, dark brown, with a few blunt tubercles, but mostly ridged; stamens 10; anthers oblong, basifixed, ca. $0.5 \mathrm{~mm}$ long; filaments thread-like, $3-4 \mathrm{~mm}$ long; perianth of 2 whorls, lacking an epicalyx; petals spatulate, not strongly clawed, (6) 7-12 $\mathrm{mm}$ long, up to $6 \mathrm{~mm}$ broad, showy, white with purple to rosy veins, and entire margins, unappendaged; sepals 5, the lobes $1-3 \mathrm{~mm}$ long, obtuse, green in the center with broad scarious to whitishmargins, glabrous, calyx tube shallowly campanulate, 1-2 mm deep; pedicels 7-20 (35) mm long, slender, glabrous; inflorescence an intricately branched, diffuse, corymb-like panicle up to half the height of the plant; bracts paired, $1.10 \mathrm{~mm}$ long, linear, glabrous, with hyaline margins toward the base; cauline leaves lanceolate to narrowly elliptic with acute to obtuse tips and shallowly clasping bases, somewhat glaucous, entire, with narrow, hyaline margins; basal leaves obovate to spatulate; petioles absent; stipules absent; stems smooth, erect or ascending, slightly swollen at the nodes, up to $70 \mathrm{~cm}$ tall (including the inflorescence); root system an annual taproot, or persisting as a short-lived perennial with fibrous lateral roots $(2 n=26,34)$.

Infraspecific Variation: Flower color variants include the following cultivars: 'Grandiflora alba,' 'Rosea,' 'Carminea,' and 'Purpurea.'

Importance: This is a relatively popular species in the garden, grown for its show of many dozen of flowers on healthy individuals. It is also cultivated widely for the florist industry. The plants may be purchased in bundles, or, more frequently, they are seen in a variety of floral arrangements, where they provide accents or fringes. The lacy, airy appearance of the inflorescences makes them a favorite in corsages as well. This species may become more widespread in the future, due to inclusion of its seeds in canned wildflower mixes. 


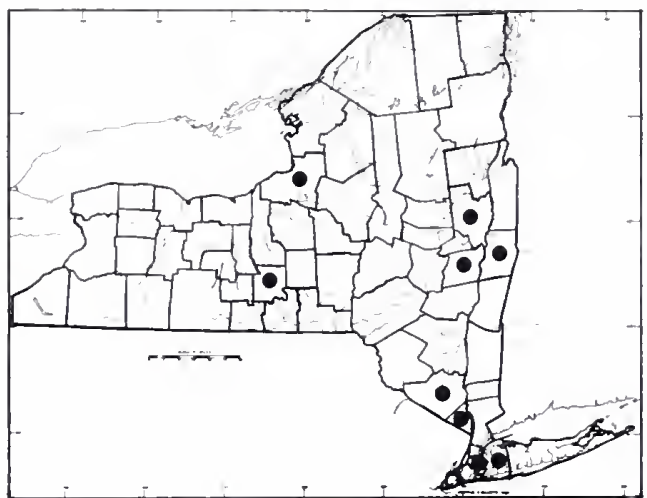

2. Gypsophila muralis I.

Common Names: Baby's-breath

Type Description: Linnaeus, Species Pl. I., p. 408, 1753

Synonyms: G. stepposa Klokov, G. pilosa of NY reports, not Huds., $G$. porrigens (L.) Boiss., of NY reports.

Origin: A native of Eurasia

Ilabitats: Dry roadsides and waste places

Ilabit: Much-branched, erect annuals

Flowering: July-October

Fruiting: July-December

General Distribution: Occasionally escaped and naturalized: Quebec to Wisconsin (Minnesota), New Jersey and southeastern Pennsylvania

Description: Plants with bisexual flowers; stigmas

2; styles filamentous, ca. $0.5 \mathrm{~mm}$ long; ovary ovoid, ca. $1 \mathrm{~mm}$ long; fruit a capsule, tan, somewhat translucent, glossy, ovoid to narrowly elliptic, 2.9 -

$3.4 \mathrm{~mm}$ long, $1.4-1.9 \mathrm{~mm}$ broad, opening by 4 acute (minutely blunt), valves that split to about $1 / 4$ the length of the fruit; seeds many, plump, comma-shaped, 0.3-0.4 mm long, ebony, the surfaces minutely muricate and bluntly ridged; stamens 10; anthers minute, basifixed; filaments slender, 2-3 mm long; perianth of 2 whorls, not subtended by an epicalyx; petals 4.0-5.3 (6) $\mathrm{mm}$ long, ca. $2 \mathrm{~mm}$ broad, spatulate, not strongly clawed, emarginate, pink with darker pink veins (purplish or white); sepals 5, the lobes obtuse, $1 \mathrm{~mm}$ long or less with green centers and broad, hyaline, ciliate margins, surfaces glabrous, the calyx tube turbinate, 1.6-2.4 (3) $\mathrm{mm}$ long; pedicels filiform, glabrous or minutely glandular, 4-14 (18) $\mathrm{mm}$ long; bracts linear-filiform, up to $1 \mathrm{~cm}$ long; inflorescence a delicately branched, complex panicle, often comprising much of the acrial portion of the plant, bearing up to a hundred or more small, pedicellate flowers; leaves capillary to linear-oblanceolate, acute, 6-15 (23) $\mathrm{mm}$ long, mostly less than $1 \mathrm{~mm}$ broad, glabrous, mealy puberulent or ciliolate along the entire margins, hyaline toward the connate bases; petioles absent; stipules absent; stems slender, wiry, much-branched above, often with only a couple of pairs of cauline leaves before branching into an inflorescence, plants 3-30 (40) $\mathrm{cm}$ tall; root system a slender, contorted, annual taproot with capillary lateral roots $(2 \mathrm{n}=34)$.

Importance: This species is cultivated as a decorative fringe, border plant and annual "filler" between perennials in rock gardens. Although not commercially important in the floral trade, it is sometimes used in bouquets. 


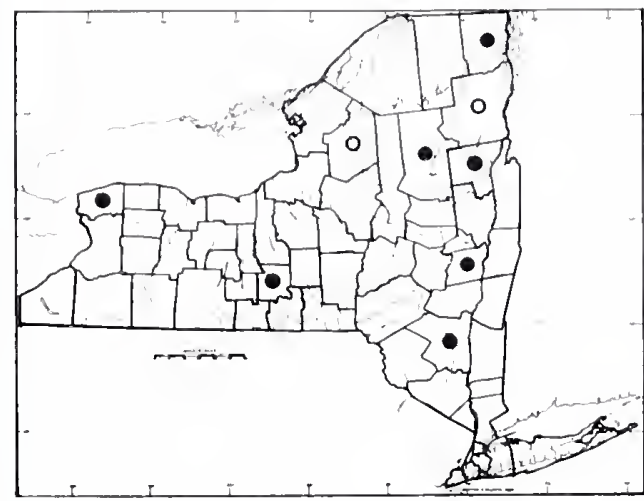

\section{Gypsophila paniculata L.}

Common Names: Baby's-breath

Type Description: Linnacus, Species Pl. I, p. 407, 1753

Synonyms: G. bicolor (Freyn \& Sint.) Grossh., G. paniculata L. ssp. bicolor Freyn \& Sint., $G$. stevenii of NY reports, not Fisch.

Origin: A native east-central Europe and central Asia

Ilabitats: Fields, waste places, meadows, ditches and roadsides

Habit: Erect or ascending, stout, herbaceous perennials

Flowering: Junc-August

Fruiting: July-October

General Distribution: Occasionally naturalized from Quebec to British Columbia, Washington, Nebraska, Indiana, New England, New York and Pennsylvania (northern Florida)

Description: Plants with bisexual flowers; stigmas 2; styles 2, filiform, ca. $2 \mathrm{~mm}$ long, golden; ovary spheroid, ca. $1 \mathrm{~mm}$ in diameter; fruit a capsule, $1.4-2.1 \mathrm{~mm}$ in diameter, spheroid, tan, glossy, enclosed within the persistent calyx, opening by 5 obtuse valves; seeds several, plump, 0.6-1.1 mm long, dark brown with rounded tubercles and ridges; stamens 10; anthers minute, globose, golden, dorsifixed; filaments pale, filamentous, slightly exserted from the perianth, 3.0-3.5 mm long; perianth of 2 whorls, lacking an epicalyx; petals 5, 2.4-3.2 $\mathrm{mm}$ long, ca. $1.5 \mathrm{~mm}$ broad, white, to pinkish or rose, shallowly emarginate, not strongly clawed; sepals 5 , dark green with broad, scarious, white margins, pale punctate on drying, the lobes 0.6-1.1 mm long, with obtuse tips, calyx tube campanulate, 0.7-1.8 mm deep; pedicels 1-9 (13) mm long, very slender, glabrous; bracts minute, linear-lanceolate with a green midrib and whitish margins; inflorescences multiple, at and near the branch tips, diffuse panicles of corymb-like clusters of minute flowers; leaves narrowly to broadly lanceolate, 1-7 (10) $\mathrm{cm}$ long, $1-8$ (11) $\mathrm{mm}$ broad, tips acute (to acuminate) bases of leaf pairs very shallowly connate at the swollen nodes, margins entire, leaf surfaces usually glabrous, glaucous; petioles absent; stipules absent; stems up to a meter tall, greenish, glaucous above (rarely pubescent), pale tan with age, up to $1.3 \mathrm{~cm}$ broad, suffrutescent toward the base; rhizome tough, woody; root system adventitious from a perennial rhizome $(2 \mathrm{n}=34)$.

Infraspecific Variation: Flower color and size vary from white to pink or redd ish between cultivars, and there is a multiple-petaled 'flore-pleno' form. Plants of so-called "ssp. bicolor" have larger flowers and broader leaves than is typical.

Importance: This is the common "baby's-breath" of the nursery and cut-flower trade, grown in great quantities and used in corsages and floral arrangements of many kinds. It is also grown in yard plantings, rock gardens and as a border plant where a lacy effect is desired. 
Note: A specimen corresponding closely with Gypsophila arrostii Guss., as treated in Flora Europaea (Tutin, et al., 1964) has been collected in Tompkins County near a plant nursery. It differs from specimens of closely related $G$. paniculata in having dark, glandular pubescence throughout the inflorescence, purple-pink petals, and even blunter, less prominent tubercles on the seeds.

\section{VACCARIA}

Common Names: Cow-herb, Cow-cockle

Authority: Medic., Phil. Bot. I, p. 96, 1789

A monotypic genus of annual herbs, sometimes included in Saponaria. Up to four species have been recognized in the past. Cow-herb is a widespread weed of cultivated fields.

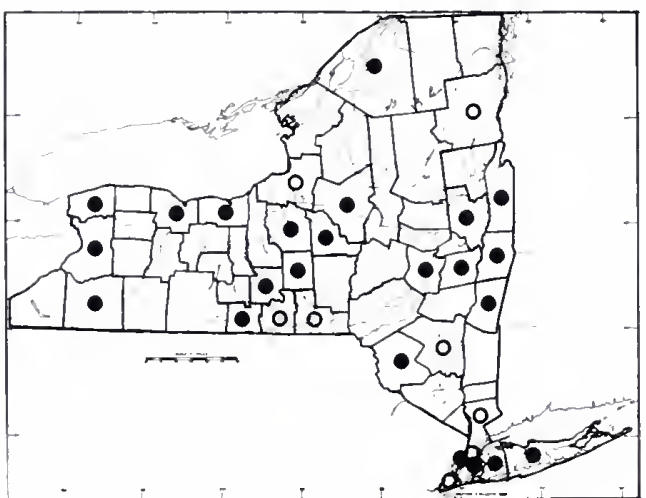

1. Vaccaria hispanica (Mill.) Rausch.

Common Names: Cow-cockle, Cow-herb, Cow-basil Type Description: Miller, Gard. Dict. ed. VIII., 1768

Synonyms: Saponaria hispanica Mill., S. vaccaria L., $V$. pyramidata Medic., $V$. segetalis (Neck.) Garcke ex Ashers., $V$. vaccaria (L.) Britton, $V$. vulgaris Host

Origin: A native of southern and central Europe

Habitats: Primarily in cultivated fields, but spreading to waste places, sidewalks and roadsides

Ifabit: Erect, often flat-topped, annual herbs

Flowering: June-September

Fruiting: July-November

General Distribution: Newfoundland to Alaska California and Louisiana (Florida)

Description: Plants with bisexual flowers; stigmas 2 ; styles 2, filamentous, $8-11 \mathrm{~mm}$ long; ovary ovoid, subsessile; fruit an ovoid capsule, almost filling the persistent, inflated calyx, the capsule tan, smooth, $6.10 \mathrm{~mm}$ long, $4-8 \mathrm{~mm}$ broad, dehiscing part-way by 4 valves or tearing with age and separation of endocarp from exocarp; seeds few to many, red-brown to ebony, spheroid, $2.0-2.7 \mathrm{~mm}$ in diameter, the surfaces minutely tubercled; stamens 10; anthers elliptic, golden, ca. $1 \mathrm{~mm}$ long, dorsifixed; filaments slender, 8-19 mm long; perianth of 2 whorls, lacking a free epicalyx; petals 5, claws linear, 8-14 mm long, paler than the limbs, petal limbs 3-9 $\mathrm{mm}$ long, $2-5 \mathrm{~mm}$ broad, lacking appendages at base, margins entire or emarginate (less often irregular), purplish, or deep rose to pink; sepals 5, lobes $1-3 \mathrm{~mm}$ long, acute, often purplish with hyaline margins, tube $12.15 \mathrm{~mm}$ long, cylindric at first, but soon inflated toward base; (in fruit) the persistent calyx up to $11 \mathrm{~mm}$ broad when fully inflated, the tube becoming flask-shaped or pyriform to broadly urceolate with 
wing-like ridges, each wing with a strong, cord-like vein at its margin, the green, glossy ridges spanned by paler concavities that are whitish to cream or pinkish-tinged; pedicels slender, $6-20 \mathrm{~mm}$ long, glabrous, pale greenish to pink-tinged, weakly to strongly ribbed; inflorescence a cyme-like panicle or dichasium of few to dozens of flowers, ovoid in outline to conspicuously flat-topped; bracts paired, connate at base, ovoid to linear-lanceolate with acute to acuminate tips, $2-10(18) \mathrm{mm}$ long, green to scarious with a green midrib; leaves ovate to obovate or broadly lanceolate, (1) $4-10(13) \mathrm{cm}$ long, (0.5) $1-4(4.8) \mathrm{cm}$ broad, tips acute to acuminate (obtuse), bases shallowly clasping, often somewhat auriculate to cordate, surfaces smooth to punctate on drying, margins entire; petioles absent; stipules absent; stems smooth, somewhat glaucous, terete or ribbed, branching above the base, erect, $15-70 \mathrm{~cm}$ tall; root system a twisted, slender to stout, annual taproot $(2 \mathrm{n}=30,60)$.

Infraspecific Variation: In certain individuals the inflated calyx bears a clear outline of five pale lobes (possibly epicalyx) incorporated into its commissures. Although these structures are totally fused with the calyx structure, their fringed margins may be raised and clearly distinguishable. Flower color varies from purple to rose, brick-red or pink (rarely white).

Importance: Like its relative, the corn-cockle (Agrostemma), cow-cockle (Vaccaria) is an aggressive invader of cultivated fields in many parts of the world. It competes readily with crops such as linseed flax, significantly decreasing productivity (Alex, 1968). The plants contain dangerous amounts of saponin and githagenin (sapogenin), especially in the fruits, and have been reported to kill both humans and livestock when ingested with grain. Modern screening processes have rendered this threat to humans negligible in commercial products, however, and livestock usually find toxic concentrations of the plants distasteful. Symptoms of githagenin poisoning are shortness of breath, vomiting and dizziness as well as gastroenteritis and lesions in severe cases. The seeds of cow-cockle are rich in starch, but suggestions that it might be grown as a starch crop have not been followed up, partially due to the necessity for extracting the poisonous compounds. Though somewhat showy, Vaccaria is not usually valued as a horticulural plant.

\section{SAPONARIA}

Conmon Names: Soapwort, Bouncing-Bet

Authority: Linnacus, Species Pl. I, p. 408, 1753

A genus of about 30 species native to Mediterranean Europe, north Africa and western Asia. Bouncing-bet or soapwort, S. officinalis L. is the only species that escapes widely in North America. It is sometimes cultivated in gardens, but it is aggressively competitive with a tough rhizome. The plants were once extracted for a crude soap. Though used in folk medicine in the past, the extract is rich in saponin and other steroid glycosides that should not be ingested in quantity. The seeds are particularly poisonous.

\section{Saponaria officinalis L.}

Common Names: Bouncing-Bet, Soapwort, London-pride, Bruisewort, Fuller's-herb, Sheepweed, Soapwort Gentian, Sweet-Betty, Bostonpink, Old-maid's-Pink, Hedge-pink, Chimneypink

Type Description: Linnacus, Species Pl. I, p. 408, 1753

Origin: A native of Eurasia

Ilabitats: Roadsides, waste places, sidewalks, vacant lots and other urban settings as well as in cultivated fields

Itabit: Erect, decumbent or ascending, robust, perennial herbs

Flowering: Late June-September

Fruiting: (June) July-November

General Distribution: Naturalized from cultivation: Newfoundland to British Columbia, Mexico,

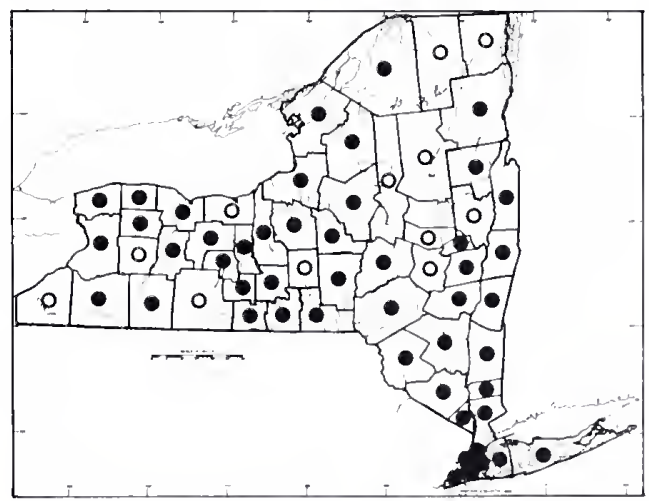


Florida and elsewhere; also weedy in Eurasia where it is native

Description: Plants with bisexual flowers; stigmas 2 (rarely 3 ), linear; styles 2 (rarely 3 ), filamentous, $16-24 \mathrm{~mm}$ long, free or fused just above a short valvate cap; ovary ovoid; fruit an ellipsoid to cylindric capsule, 12-18 mm long, 2.9-6.8 mm broad, subsessile within the persistent calyx, smooth, tan, opening by 4 (6) narrow valves about $1 / 3$ its length; seeds many, comma-shaped, plump, though somewhat compressed, $1.8-2.0 \mathrm{~mm}$ long, brown to ebony with muricate surfaces; stamens 10 ; anthers ca. $1.5 \mathrm{~mm}$ long, golden to pinkish, dorsifixed; filaments slender, up to $3 \mathrm{~cm}$ long; perianth of 2 whorls, not subtended by an epicalyx; petals 5, claw 1-20 (26) $\mathrm{mm}$ long, ca. $2 \mathrm{~mm}$ broad, limb 5-11 (16) $\mathrm{mm}$ long, 3-9 (13) $\mathrm{mm}$ broad, entire, emarginate or cleft, with a pair of coronal scales 1-2 mm long borne at the at the junction of limb and claw, corolla and fringe white to pink; sepals 5, lobes $2-4 \mathrm{~mm}$ long, acuminate to caudate, sometimes lacerate, margins with a ciliate fringe, calyx tube 16-21 (27) $\mathrm{mm}$ long, 3-7 $\mathrm{mm}$ broad, cylindric to slenderly ovoid, greenish, with ca. 20 ribs, not strongly inflated in fruit; pedicels glabrous, ribbed, mostly $1-3 \mathrm{~mm}$ long; peduncles bearing flower clusters mostly $1.5 \mathrm{~cm}$ long or less; inflorescences dichasial, of congested, cyme-like fascicles, borne terminally and in the upper leaf axils; bracts paired, connate at base, lanceolate and acuminate to long-attenuate, mostly $1.4 \mathrm{~mm}$ long, the margins sometimes ciliate near the node;

leaves broadly elliptie or obovate to ovate-lanceolate (2) $5-8$ (12) cm long, (1) 2-4 (5) cm broad, margins entire, often minutely revolute and papillose, blade glabrous (to puberulent), with 3 major pseudo-parallel veins arching from the base to near the acute to rounded leaf tip, bases attenuated, often to a petiole $2-5 \mathrm{~mm}$ long, barely clasping at base; stipules absent; stems terete, with swollen nodes at which they often bear small, leafy short-shoots, sparsely opposite-branched upward, stalks green to tan or pinkish tinged, erect or ascending up to a meter tall (or nodding), densely colonial from perennial bases; rhizomes much-branched, mostly 4-8 $\mathrm{mm}$ broad, often arched upward at the plant base into a caudex, with pale, yellowish wood; root system finely fibrous, largely adventitious from the nodes of the rhizomes $(2 n=14,28)$.

Infraspecific Variation: Plants with sterile, multi-petaled, flore pleno flowers are not uncommon in the northern parts of their native range in Eurasia and also as escapes in north-temperate North America.

Importance: Bouncing-bet continues to be grown in gardens, but it was once far more widely cultivated. It has perhaps decreased in popularity because of its weediness and association with abandoned lots, back streets and waste places. It is an aggressive, colonial plant, self-propagating from woody, perennial rhizomes, and, in extreme cases, it may become a pest requiring eradication in both urban and agricultural settings. Another common name, "soapwort," comes from the fact that a lather that can be derived by crushing the plants in water. This extract has been used as a soap substitute and a base for homemade and commercial shampoos. The plants have medicinal and folk uses, but the poisonous saponin content has proved dangerous, and demands strict precautions. Europeans and early American settlers used decoctions to treat arthritis, venereal disease, jaundice and a number of other health problems, including external application of poultices for such complaints as itches, warts and bruises. Poisoning and death may result from ingestion of quantities of any portion of the plant, but the seeds are particularly dangerous, since they are richest in saponin and githagenin. 
They pose a threat to both humans and livestock, especially if chewed. Symptoms of saponin poisoning include, dizziness, vomiting and shortness of breath, and toxic doses may result in gastroenteritis and lesions as well.

Note: Saponaria ocymoides L., the rock soapwort, is a European native that has been found once in New York State, naturalized in a hollow in Ulster County (1967). It has spatulate leaves and bright purplish to pink flowers about a centimeter long, with densely glandular-pubescent calyces.

\section{LYCIINIS}

Common Names: Campion, Lychnis, Pink

Authority: Linnacus, Species P1, I, p. 436, 1753

A genus of about 15 species distributed widely in Europe and eastern Asia. Species reported from North Africa and South America are referable to Silene. The characters separating Lychnis from the closely related genus, Silene, have been subject to interpretation, such that some taxa have been transferred back and forth between genera. Certain Lychnis species can be quite showy, with scarlet, orange, purple, rose, pink or white flowers, and a number of them have found wide acceptance as garden ornamentals.

Description: Plants with bisexual flowers; stigmas usually 5; styles usually 5; ovary 1, gynophore present or absent; ovules many; fruit a capsule, on a carpophore or subsessile, unilocular or 3-5 septate from the base, dehiscing by 5 acute or bifid valves; seeds copious, small, somewhat compressed, muricate or tuberculate; embryo curved around the perisperm; stamens 10; anthers dorsifixed; filaments slender; perianth of 2 whorls, lacking an epicalyx; petals free, white, purple, pink, orange or red, each strongly divided into a limb and claw, usually with a fringe of coronal scales where they join at the corolla mouth; sepals 5, united for most of their lengths into a cylindric calyx tube that may become somewhat inflated in fruit; pedicels and peduncles slender to stout; inflorescences variously cymose to paniculate, diffuse to densely clustered; bracts paired; leaves paired, entire, their bases connate at the node; petioles present or absent; stipules absent; stems erect or ascending from perennial rhizomes and fibrous adventitious root systems.

\section{KEY TO SPECIES}

1. Surface of the calyx tube glabrous; petal margins dissected into linear lobes and teeth; corolla white, pink,

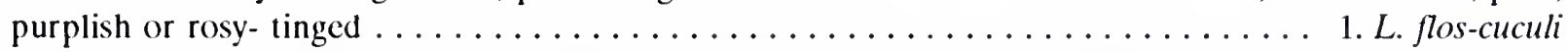

1. Surface of the calyx tube sparsely to densely pubescent; petal margins entire, emarginate or deeply bifid, but not dissected; corolla orange, scarlet, or pale red to dark reddish-purple (rarely white) . . . . . . . (2) 2. Inflorescence a congested cyme, the pedicels less than $0.5 \mathrm{~cm}$ long; petal tips conspicuously bifid-notched; plants sparsely pubescent, not silvery-tomentose; mature capsule stalked within the clavate calyx tube .

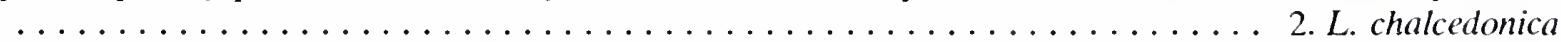

2. Inflorescence not congested, few-flowered, pedicels mostly $2-10 \mathrm{~cm}$ long; petals entire to emarginate, but not strongly bifid; plants grayish, often densely woolly-tomentose; capsule subsessile within the obovoid calyx tube .............................. . coronaria 


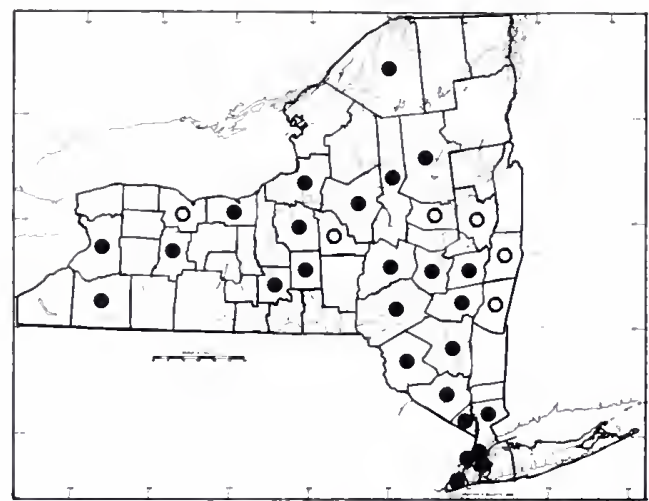

1. Lychnis flos-cuculi L.

Common Names: Cuckoo-flower, Ragged Robin, Crowflower, Meadow-pink, Cuckoos, Indianpink, Ragged-jack

Type Description: Linnaeus, Species Pl., I, p. 436, 1753

Synonyms: Coronaria flos-cuculi (L.) A. Braun

Origin: A native of northern and central Europe

Habitats: Roadside depressions, open fields and moist meadows

Ilabit: Slender, erect-ascending, perennial herbs

Flowering: May-July

Fruiting: June-September

General Distribution: Escaping cultivation and becoming naturalized from New Brunswick, Nova Scotia and Quebec to New York, New Jersey and Pennsylvania

Description: Plants with bisexual flowers; stigmas 5; styles 5, filamentous, $3-5 \mathrm{~mm}$ long; ovary ovoid, sessile; fruit an ovoid capsule, 6-9 $\mathrm{mm}$ long, 4-6 $\mathrm{mm}$ broad, subsessile, dehiscing by 5 reflexing valves 2-3 $\mathrm{mm}$ long, the surface smooth, greenish to tan; seeds many, 0.6-0.8 $\mathrm{mm}$ long and broad, somewhat compressed, reniform, the surfaces brown, covered with sharp turbercles; stamens 10; anthers linear, ca. $1.5 \mathrm{~mm}$ long, dorsifixed; filaments slender, 6-9 mm long; perianth of 2 whorls, not subtended by an epicalyx; petals 5, claw slender, often pale, $5-8 \mathrm{~mm}$ long, ca. $1 \mathrm{~mm}$ broad or less, petal limb 6-10 (13) $\mathrm{mm}$ long, bifid, but usually further dissected into linear lobes and teeth for up to $2 / 3$ its length, appendaged at the junction with the claw with 2 slender, bifid or lacerate coronal scales $2-3 \mathrm{~mm}$ long, corolla rose, bluish purple or pale pink to white; sepals 5, the lobes deltoid, acute to obtuse 2-3 (4) $\mathrm{mm}$ long, with copiously ciliate margins, the calyx tube becoming inflated in fruit, $5-8 \mathrm{~mm}$ long, $2-7 \mathrm{~mm}$ broad, glabrous, glossy, purplish to dark rose, especially along the 10 prominent ribs, often yellow-green or glaucous between them; pedicels slender, 1-12 (16) $\mathrm{mm}$ long, sparsely woolly-viscid, red-purple; peduncles similar, but up to $6 \mathrm{~cm}$, strongly ascending; inflorescence often symmetrical, a slender series of 2.4 pairs of upper-axillary and terminal corymbs; bracts reddish-purple, linear to lanceolate, mostly 1-6 (13) mm long, with ciliate-fringed margins; cauline leaves paired, linear to broadly lanceolate, oblanceolate or spatulate, $1-6(10) \mathrm{cm}$ long, $1-5(8) \mathrm{mm}$ broad, margins minutely revolute, glabrous or slightly ciliate on young leaves and those transitional to bracts, tips acuminate to obtuse green, often red or purple tinged, ciliate or bearded at the junctures of the leaf bases that are attenuated into poorly defined petioles and barely connate-clasping, basal leaves similar to the lower cauline ones, but more obovate to spatulate with (acute) obtuse to rounded tips, up to $14 \mathrm{~cm}$ long, $15 \mathrm{~mm}$ broad, borne in a cespitose clusters or rosettes, the petioles sometimes relatively well-defined, up to $4 \mathrm{~cm}$ long; stipules absent; stems terete to strongly ridged and furrowed, puberulent, especially on the upper nodes, erect, up to $70 \mathrm{~cm}$ tall, little branched 
above, but proliferating by densely branching hasal shoots and rhizomes; root system soft-fibrous, matted, adventitious $(2 \mathrm{n}=24)$.

Infraspecific Variation: Lychnis flos-cuculi ssp. subintegra Hayek was described from the Balkan Peninsula, with bifid-emarginate (but uncut) lobe tips. Such plants have not been recorded as naturalized in New York State. Importance: This is a popular garden ornamental, planted in sunny places in relatively moist, northern climates. Its spread as a weed was largely coincidental with the construction of the Interstate highway system in the Northeast.

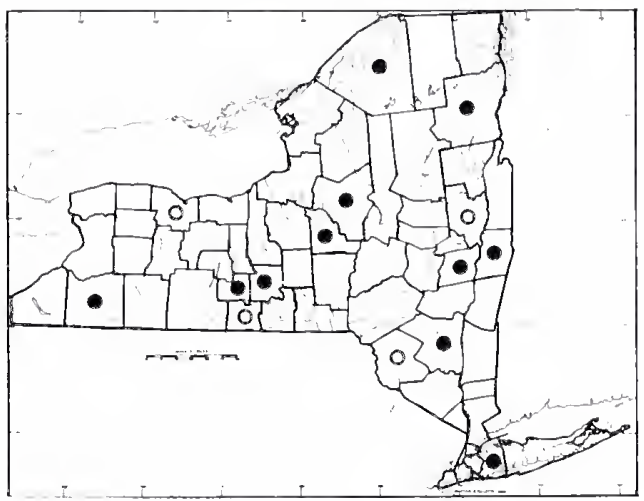

2. Lychnis chalcedonica $\mathrm{L}$.

Common Names: Maltese Cross, Scarlet Lychnis, London Pride, Fireballs, None-such, Jerusalem Cross, Knight's Cross

Type Description: Linnaeus, Species Pl., p. 436, 1753

Origin: A native of Northern Eurasia

IIalitats: Escaping to woodland borders, meadows, fields, roadsides, waste places and thickets

IIabit: Erect or spreading, leafy perennial herbs

Flowering: June-September

Fruiting: July-November

General Distribution: Escaped from cultivation in North America from Newfoundland to Minnesota, south to Pennsylvania

Description: Plants with bisexual flowers; stigmas minutely papillose receptive areas $1-2 \mathrm{~mm}$ long on the dorsal tips of the styles; styles 5 (6), free, capillary, 3-6 mm long, green, somewhat spreading from the ovary tip, green, purplish toward the stigmatic zone; ovary obovoid-cylindric 4-5 mm long, ca. $3 \mathrm{~mm}$ broad, shiny green, glabrous, borne on a gynophore; fruit a shiny, ovoid, tan capsule, enclosed in the persistent calyx tube, dehiscing by 5 (6) acute-tipped valves for less than a third its length, 7-9 $\mathrm{mm}$ long, 5-7 mm broad, borne on a carpophore 6-11 mm long, and included in the clavate, persistent calyx tube; seeds copious, ca. 0.8 $\mathrm{mm}$ broad, brown, tuberculate; stamens 10 , attached just below the ovary at the apex of the androgynophore; anthers ca. $1 \mathrm{~mm}$ long, golden-brown or orangish; filaments slender 4-13 mm long, curved outward toward tips, greenish hyaline below, orange toward tips; perianth of two whorls, with a fringe of ligule-like appendages at the base of the petal limbs; petals free, distinctly divided into claw and limb, the claw 13-19 (21) $\mathrm{mm}$ long, strap-like, barely exceeding the calyx tube, very narrow an greenish below, expanded and 3-4 mm broad above, where it is somewhat membranous and hyaline with a small keel on the abaxial side and a few hirsute hairs at the margin, the limb diverging at a right angle from the claw tip, $5-13$ (16) $\mathrm{mm}$ long, 4-12 $\mathrm{mm}$ broad, oblanceolate to obspatulate, tip bifid, the notch $2-6 \mathrm{~mm}$ deep with a rounded sinus, lobes entire or slightly erose, scarlet to bright orange-red (rarely white), 2 ligulate coronal scales borne at the limb hase (claw apex), ovate to lanceolate-tubular, $1.8-3.6 \mathrm{~mm}$ long, ca. $1 \mathrm{~mm}$ broad, acute or notched at tips, colored like the petal 
limbs; sepals 5, lobe tips acuminate, narrowly hyaline-margined, 2-6 mm long, calyx tube cylindric, 12-17 (20) $\mathrm{mm}$ long, green, 10-ribbed, hirsute to sparsely woolly with septate hairs, persistent, becoming clavate and somewhat inflated (up to $8 \mathrm{~mm}$ in diameter) around the stalked fruit; pedicels stout, hispid, 2-3 (4) $\mathrm{mm}$ long; peduncles like the pedicels, usually less than $1 \mathrm{~cm}$ long; inflorescence a dense, terminal cyme, flat-topped to hemispheric, often $4-10 \mathrm{~cm}$ broad; bracts of the inflorescence linear-lanceolate, $3-20 \mathrm{~mm}$ long, $1-4 \mathrm{~mm}$ broad, slightly hispid, particularly at the margins; leaves opposite, somewhat leathery, elliptic, ovate to ovatelanceolate or oblanceolate, $2-8(14) \mathrm{cm}$ long, $1-4(6) \mathrm{cm}$ broad, with acute to obtuse tips, the bases attenuate to rounded, the lower ones often cordate and somewhat clasping, partially to wholly connate at the nodes, upper cauline leaves ciliate on margins and major veins, but the surfaces almost glabrous, lower leaves hirsute to sparsely villous throughout; petioles absent; stipules absent; stems erect or strongly ascending, 2-14 mm thick, tough, up to a meter tall or more, sparsely hirsute to moderately villous, not much branched, but with short, suppressed shoots bearing dwarf leaves (shoots) at the slightly enlarged nodes; rhizomes tough, woody; root system largely adventitious, fibrous $(2 \mathrm{n}=18,24,48)$.

Infraspecific Variation: White-flowered variants occur, but these are less commonly cultivated than those with orange, rose or salmon hues. There is also a large-flowered, 'Grandiflora' cultivar.

Importance: This is a showy garden perennial, grown widely around the world in north-temperate climates, escaping occasionally, but not usually extremely aggressive as a weed.

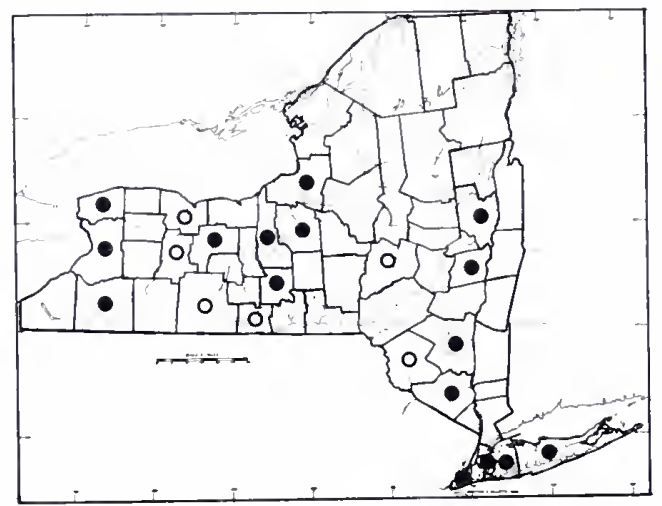

3. Lychnis coronaria (L.) Desr.

Common Names: Rose-campion, Mullein Pink, Gardener's-delight

Type Description: Linnaeus, Species Pl, I., p. 436, 1753

Synonyms: Agrostemma coronaria L., Coronaria coriacea (Moench) Schischk. \& Gorschk.

Origin: A native of southeastern Europe

Ilabitats: Roadsides, fields, clearings, shores, borders and woodlands as a naturalizing escape from cultivation

Iabit: Erect, rhizomatous perennial herbs

Flowering: June-August

Fruiting: June-September

General Distribution: New Brunswick to British Columbia, south to Oregon and Louisiana, escaping cultivation and naturalized in widely scattered places between

Description: Plants with bisexual flowers; stigmas (4) 5, linear; styles (4) 5, filamentous, 2-3 (5) mm long; ovary ovoid, subsessile; fruit an elliptic to obovoid-cylindric capsule, smooth, tan, 9-14 (17) mm long, 6-10 (13) $\mathrm{mm}$ broad, sessile or carpophore less than $2 \mathrm{~mm}$ long, opening by 5 acute valves $2-4 \mathrm{~mm}$ long that are often shallowly bifid; seeds many, $0.5-0.8 \mathrm{~mm}$ long and broad, plump, gray-brown to black, bluntly tuberculate; 
stamens 10; anthers narrow, ca. $2 \mathrm{~mm}$ long, dorsifixed; filaments slender, 10-14 mm long; perianth of 2 whorls, lacking an epicalyx; petals 5, divided into claw and limb, the claw paler than the limb 10-15 (20) mm long, 2-3 $\mathrm{mm}$ broad, the limb broadly oval to obovate, up to $17 \mathrm{~mm}$ long and broad, pale red to dark red-purple (rarely white), margin entire or shallowly emarginate, coronal scales borne in pairs, slightly included within the corolla at the limb-claw junction, lance-acuminate or shallowly bifid, $2-3 \mathrm{~mm}$ long; sepals 5 , the free lobes attenuate, $3-5 \mathrm{~mm}$ long, often tortuous to spirally contorted, densely to sparsely woolly-tomentose, the calyx tube (8) 1014 (20) $\mathrm{mm}$ long, obovate, becoming inflated and up to $14 \mathrm{~mm}$ broad in fruit, 10-ribbed, the ribs somewhat raised and darker green, the calyx tube surface covered with a dense, gray to silvery, woolly tomentum; pedicels stout, up to $3 \mathrm{~mm}$ in diameter, $1-12 \mathrm{~cm}$ long, clongating as the flower develops; inflorescence of several axillary and terminal, obscurely cymose clusters, the flowers (often 3 per cluster) developing, one at a time, the pedicel greatly-clongating during development (or rarely flower solitary); bracts leaf-like, $4-20 \mathrm{~mm}$ long, up to $5 \mathrm{~mm}$ broad, broadly lanceolate with acute to acuminate tips and entire margins, woolly-tomentose, directly subtending the short pedicels before elongation, but remote by the time of flowering; leaves dimorphic, cauline leaves paired, mostly $2-8(11) \mathrm{cm}$ long, $1-3$ (4) $\mathrm{cm}$ broad, broadly lanceolate to elliptic or obovate with entire margins, densely woolly-tomentose, gray to silvery surfaces, margins, a strong midrib, apiculate to acute or obtuse (rounded) woolly-tufted tips, and bases tapering or slightly auriculate at the point where clasp the stem, basal leaves like the cauline ones, except densely clustered in rosettes, up to $25 \mathrm{~cm}$ long and $5 \mathrm{~cm}$ broad, narrowly to broadly obovate to spatulate, and often tapered at base into poorly defined petioles; stipules absent; stems terete, woolly-tomentose, up to $7 \mathrm{~cm}$ in diameter and $85 \mathrm{~cm}$ tall, erect or ascending from a woody rhizome; root system adventitious $(2 \mathrm{n}=24)$.

Infraspecific Variation: Flower color is quite variable in cultivars, ranging from rose to salmon, brick-red, purple or white.

Importance: This is a showy garden perennial or biennial, grown almost worldwide, that escapes and becomes naturalized widely in Eurasia and northern North America.

Note: Lychnis viscaria L., German catchlly, has been reported as a rare escape in New York State. The plants have spike-like panicles of rosy flower clusters, zones of viscous hairs at the internodes, and the basal rosettes of oblanceolate leaves.

\section{SILENE}

Common Names: Campion, Catchfly, Pink

Authority: Linnacus, Species Pl. I, p. 416, 1753

A genus of 500-700 species, native primarily in north-temperate, boreal and montane habitats around the world. The group is best represented in Eurasia. A reinterpretation of generic characters has led to the transfer of certain species from the closely related genus Lychnis into Silene. The showier species, called pinks, catchflies and campions, are popular in horticulture, grown widely in borders, annual and perennial beds, especially in rock gardens.

Description: Plants with bisexual flowers or dioccious; stigmas 3 (4 or 5); styles 3 (4 or 5); ovary 1, usually stalked, unilocular 3- to 5-chambered, or partially so toward the base; ovules numerous; fruit a capsule, opening by 6 ( 8 or 10 ) teeth, borne on a carpophore or subsessile; secds many, small, often muricate or tuberculate; embryo strongly curved around the perisperm; stamens 10; filaments slender; anthers dorsifixed; perianth of 2 distinct whorls, lacking a distinct epicalyx; petals 5, free, usually strongly divided into a narrow, basal claw (sometimes auricled) and flared limb that is often bifid or otherwise cut; coronal scales present at the junction of the petal claw and limb (or absent); sepals 5, with short, free lobes, united for most of their length into a calyx tube, 10-35 + veined, persistent and becoming more or less inflated in fruit; pedicels slender to stout; inflorescences various, often cymose or paniculate, or flowers solitary; bracts paired or whorled, sometimes leaf-like; leaves paired, entire, connate-clasping at base; petioles usually absent or poorly defined; stipules absent; stems erect or ascending or cespitose, from perennial rhizomes, annual or bicnnial taproots. 


\section{KEY TO SPECIES}

1. Cauline leaves mostly in whorls of 4 , subequal in size; petal margins conspicuously lacerate-fringed ....

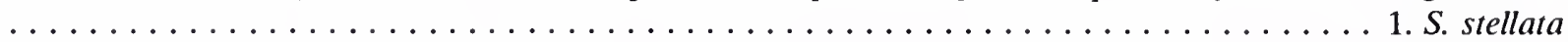

1. Cauline leaves paired (sometimes with clusters of smaller leaves in their axils); petals margins not fringed,

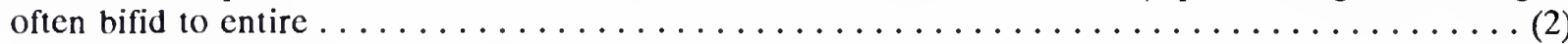

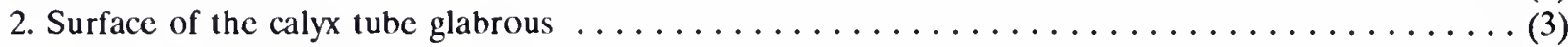

2. Surface of the calyx tube pubescent $\ldots \ldots \ldots \ldots \ldots \ldots \ldots \ldots \ldots \ldots \ldots \ldots \ldots \ldots \ldots \ldots$ (6)

3. Petals white (rarely pink-tinged); internodes lacking viscous zones; calyx veins inconspicuous, branching, up

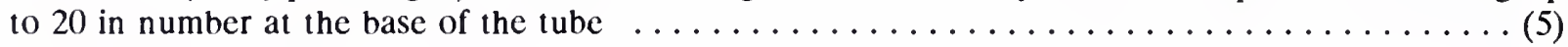

3. Petals pink, red, purple or lacking (rarely white); internodes often with golden to dark viscous zones; veins of the calyx tube 10 or fewer, unbranched, often prominent or ridged . . . . . . . . . . . (4)

4. Ovary distinctly stalked; fruiting calyx tube conforming to the stalked capsule within, to become cylindricturbinate; petals showy . . . . . . . . . . . . . . . armeria

4. Ovary subsessile; fruiting calyx tube conforming closely to the sessile, elliptic-obovoid capsule; petals usually inconspicuous and thread-like (or lacking) ................ antirrhina

5. Stipe of the capsule (within the calyx tube) minutely pubescent, ca. $1.5 \mathrm{~mm}$ long; calyx closely conforming to the mature fruit, its veins not conspicuously netted; capsule teeth narrow, acuminate, exserted from the calyx on dehiscence ................................ 4. . cserii

5. Stipe of the capsule glabrous, usually $2-3 \mathrm{~mm}$ long; the calyx conspicuously inflated in fruit, its veins strongly reticulate; capsule teeth acute, not usually exserted from the calyx after dehiscence ..... 5. S. vulgaris 6. Plants cespitose, with dense tufts of oblanceolate to broadly spatulate basal leaves; flowering stems with 1-3 pairs of cauline leaves, usually less than $20 \mathrm{~cm}$ tall, with clustered, showy, terminal cymes. ...

6. S. caroliniana

6. Plants not cespitose; flowering stems elongate, usually with many pairs of cauline leaves; inflorescences ranging from spikes to open cymes and panicles $\ldots \ldots \ldots \ldots \ldots \ldots \ldots \ldots \ldots \ldots \ldots$ (7)

7. Flowers sessile or subsessile, borne in pairs of spike-like cymes at the branch tips (sometimes in upper leaf axils as well); fruiting calyces remaining subsessile, appressed upward against the axis . 7. S. dichotoma

7. Flowers mostly with well-developed pedicels, in open cymes or panicles; fruiting calyces not appressed upward on the axis of the infructescence . . . . . . . . . . . . . . 8. Capsule teeth 6 ; styles 3 ; flowers bisexual, their subtending floral bracts narrowly lanceolate; seeds graybrown with blunt, dark-tipped tubercles .................... 8. noctiflora

8. Capsule teeth 10; styles 5; flowers unisexual, the subtending bracts deltoid to broadly lanceolate; seeds brown with evenly colored, blunt to acute tubercles $\ldots \ldots \ldots \ldots \ldots \ldots \ldots \ldots \ldots$. . . . . . .

9. Flowers white; capsule ovoid, the aperture somewhat constricted on dehiscence, the marginal teeth erect or slightly spreading $\ldots \ldots \ldots \ldots \ldots \ldots \ldots \ldots \ldots \ldots \ldots \ldots \ldots \ldots \ldots \ldots \ldots \ldots \ldots \ldots$. Latifolia

9. Flowers rose or pink (rarely white); capsule globose, often gaping on dehiscence, the teeth strongly reflexed

10. S. dioica 


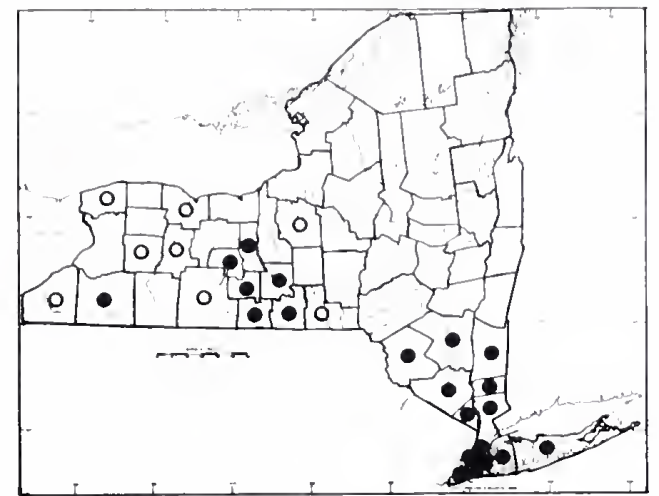

1. Silene stellata (L.) Ait. f.

Common Names: Starry Campion, Widow's-frill, Thermon Snakeroot, Four-leaved Campion

Type Description: Linnacus, Species Pl. 1., p. 414, 1753

Synonyms: Cucubalus stellatus L., Evactoma stellata

(L.) Nicuwl., E. stellata var. scabrella Nieuwl.,

S. stellata var. scabrella (Nicuwl.) Palmer \&

Stcyerm., S. scabrella (Nicuwl.) G. N. Jones

Origin: Native to eastern North America

Ilabitats: Dry, rocky places including woodlands, thickets, clearings, banks and forest margins

IIabit: Erect to ascending, somewhat woody, perennial herbs

Flowering: July-October

Fruiting: July-December

General Distribution: Massachusetts to North

Dakota, south to Texas and Georgia

Description: Plants with bisexual flowers; stigmas 3, papillose areas near the style tips; styles 3, slender, 11-17 $\mathrm{mm}$ long, exserted from the corolla, free to the base, where they are attached on a pale, hemispherical swelling or cap formed by the valves; ovary 1, borne on a short stipe (androgynophore); fruit a highly glossy capsule, olive green to tan, elliptic $5-8 \mathrm{~mm}$ long, $4-6 \mathrm{~mm}$ broad, dehiscing by 6 sharp, triangular valves that reflex strongly, further splitting the capsule to about $2 / 3$ its length; carpophore minutely woolly, $1-2 \mathrm{~mm}$ long; seeds many, dark golden to reddish-brown, reniform, somewhat compressed, $1.2-1.6 \mathrm{~mm}$ long, ca. $1 \mathrm{~mm}$ broad, surfaces rugose, with rounded papillac; stamens 10 ; anthers pale, clongate, ca. $1 \mathrm{~mm}$ long, dorsifixed; filaments slender, $7-13 \mathrm{~mm}$ long, attached at the expanded upper rim of the stipe; perianth of 2 whorls; petals 5, pale pink or white, $13-22 \mathrm{~mm}$ long, claw ca. $1 \mathrm{~mm}$ broad, limb 3-6 mm broad, the margin fringed with lacerations up to $5 \mathrm{~mm}$ decp, coronal scales lacking; sepals 5, calyx lohes $3-5 \mathrm{~mm}$ long, 3-6 $\mathrm{mm}$ broad, acuminate to apiculate, with some hyaline tissue at the margins, the calyx tube cylindric-turbinate in flower, becoming inflated and campanulate in fruit, 7-12 mm long, up to $13 \mathrm{~mm}$ broad in fruit, the surface pale green, sparsely to densely puberulent; pedicels 3-9 $\mathrm{mm}$ long, hispidulous to short-woolly; inflorescence an elongate, compound dichasium, with spreading lower branches; bracts of the inflorescence paired, $2-8 \mathrm{~mm}$ long, ciliate-margined greenish with somewhat hyaline margins; leaves mostly borne in whorls of 4 (rarely 6 ) or paired near the inflorescence or stem base, (3) $4-11 \mathrm{~cm}$ long, (0.5) $1-5$ (6) cm wide, broadly ovate to narrowly lanceolate, with long-acuminate tips and rounded to attenuate bases, clasping at the swollen nodes, leaf margins entire, often scabrescent, upper leaf surfaces often scabrescent, the lower scabrescent to puberulent; petioles absent; stipules absent; stems up to $1 \mathrm{~m}$ tall, erect-ascending, tough, woody, the nodes swollen into conspicuous woody collars, stem surfaces green or reddish on lower internodes, puberulent to short hispid; rhizome tough, woody; root system adventitious, fibrous $(2 \mathrm{n}=48)$. 
Importance: Frequent in gardens as an interesting horticultural novelty, due to its woody canes with star-like leaf whorls and fringed flowers. These plants are grown in sunny gardens and along borders where erect, perennial plants up to a meter tall are preferred.

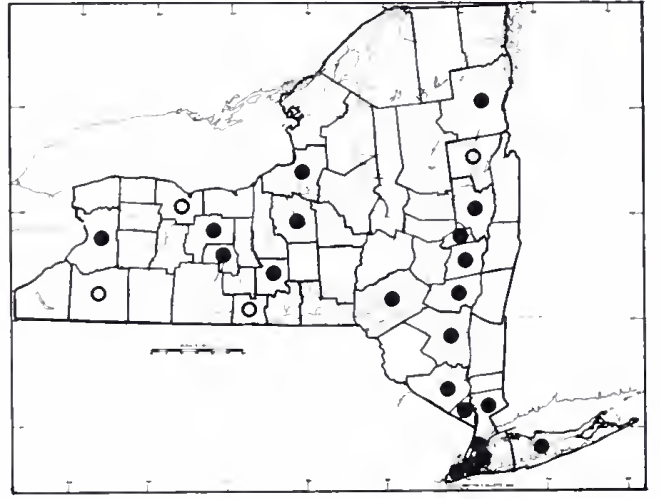

2. Silene armeria $\mathbf{L}$.

Common Names: Sweet-William, Garden Pink, Catchfly, or Campion, None-so-pretty

Type Description: Linnaeus, Species Pl. Ed. 2, p. 601,1762

Synonym: S. glauca Salisb. S. lituanica Zapal.

Origin: A native of Eurasia

Habitats: A garden escape, apparently requiring soil disturbance to become naturalized: roadsides, construction sites, vacant lots and dumps

IIabit: Erect-ascending annual or biennial herbs

Flowering: June-October

Fruiting: Late June-November

General Distribution: Widely escaped from cultivation from Quebec to British Columbia, southward to California and Arkansas (South America); also escaped in Africa and in Eurasia, where it was originally native

Description: Plants with bisexual flowers; stigmas

3 (4) linear, puberulent; styles 3 (4), filamentous, hyaline, 4.8-5.2 mm long; ovary 1, green, cylindric, 3-4 mm long, ca. $1 \mathrm{~mm}$ broad, borne on a stipe consisting of a gynophore ca. $1 \mathrm{~mm}$ long, terminal to a columnar androgynophore, $6-14 \mathrm{~mm}$ long in flower, $0.6-1.1 \mathrm{~mm}$ broad; fruit an almost completely 3-chambered capsule, smooth, tan, cylindric, 5-9 (10) $\mathrm{mm}$ long, 2.1-3.2 $\mathrm{mm}$ broad, enclosed within the persistent calyx, dehiscing by 6 (rarely 8 ) recurving teeth, ca. $1.3 \mathrm{~mm}$ long; carpophore $7-16 \mathrm{~mm}$ long, ca. $1 \mathrm{~mm}$ broad, glabrous; seeds many, dark brown, reniform and laterally compressed with sharp edges, $0.6-0.7 \mathrm{~mm}$ long, irregularly rugulose; stamens usually 10, diverging ca. $1 \mathrm{~mm}$ below the ovary base, with the claw and petal bases; anthers oblong, flat, 0.5-1.1 $\mathrm{mm}$ long, pale yellow or colored like the petals; filaments white, thread-like, $0.8-1.3 \mathrm{~mm}$ long their lower extremities sheathing, adnate to the androgynophore for most of its length; perianth of 2 whorls; petals 5, the claws greenish, linear-oblanceolate, up to $1.6 \mathrm{~mm}$ broad at the junction with the limb, where they bear a pair of ligulate appendages (coronal scales) $2-3 \mathrm{~mm}$ long, ca. $1 \mathrm{~mm}$ broad, colored like the petal limbs, but free and erect, petal limbs diverging at right angles to the claws (as in salverform corollas) pink to deep rose, lavender (or white), 4.5-6.5 mm long, 4.1-5.6 mm broad, bilobed, emarginate, or slightly ragged at tip, somewhat pleated toward the base; sepals 5 , the lobes ca. $1 \mathrm{~mm}$ long, brownish, even in flower, acute to obtuse or mucronate, calyx tube 12-15 (17) mm long, cylindrical, expanded gradually toward the tip, pale green to pinkish, conspicuously 10-ribbed and fluted, persistent in fruit, becoming clavate with the development of the capsule and shrinkage in the area of the stipe; pedicels glabrous, $2-5 \mathrm{~mm}$ long, or absent; peduncles stiff, glabrous, 8-16 (22) mm long; inflorescences congested, terminal and axillary flat-topped cymes and panicles 
of few to many flowers; inflorescence bracts lanceolate with mucronate tips, greenish to almost white, those directly subtending calyx tubes ca. $2 \mathrm{~mm}$ long, up to $6 \mathrm{~mm}$ or longer below; cauline leaves mostly $1.6 \mathrm{~cm}$ long, $0.5-2.5(3) \mathrm{cm}$ broad, ovate to narrowly oblanceolate, glabrous, margins entire, tips acute to rounded. bases attenuate to rounded or slightly cordate, clasping; basal leaves like the cauline leaves, but obovate to spatulate and soon withering; petioles absent; stipules absent; stems strongly ribbed and channeled, pale greenish-tan, glabrous to sparsely puberulent, $15-40(55) \mathrm{cm}$ tall unbranched or with ascending flowering branches; root system a short, abruptly tapered annual or biennial taproot with strong laterals and fibrous rootlets $(2 \mathrm{n}=24)$. Infraspecific Variation: Stems may be simple or much-branched above, varying from glabrous and glaucous to puberulent and dark green. Diffusely branched plants with non-congested inflorescences are known in the wild in the eastern Mediterranean Region, and such plants have been found as escapes in upstate New York, sometimes designated $S$. armeria var. sparsiflora Schur. Flower color is variable from pink to purple or white, and plants with almost entire petals have been called var. lituanica Zapal. Such variants probably do not deserve taxonomic recognition.

Importance: This is a very popular, showy plant in cultivation, where it behaves as an annual. Seeds are often collected in fall and sown in tilled soil in the spring to promote germination.

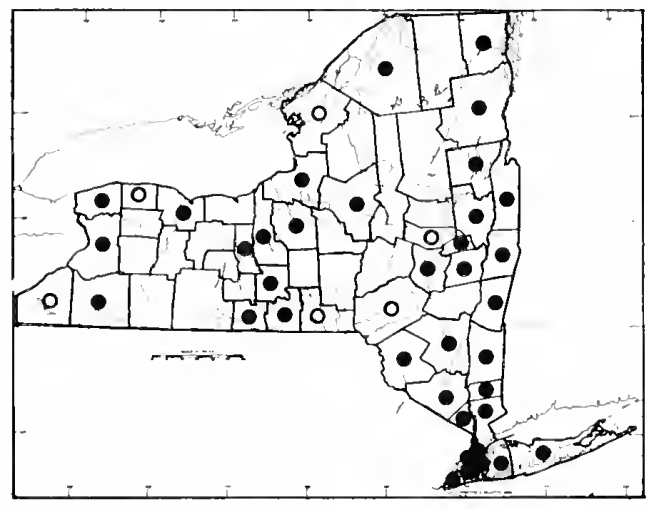

3. Silene antirrhina L.

Common Names: Sleepy Catchfly

Type Description: Linnaeus, Species Pl. I, p. 419, 1753

Synonyms: S. antirrhina: var. depauperata Rydb.; var. divaricata Robins.; forma apetala Farw.; f. bicolor Farw.; f. deaneana Fern., S. divaricata (Robins.) Smyth

Origin: Native to the Americas

Habitats: Clearings, meadows, fields, open wood lands, roadsides and waste places (a somewhat weedy native plant)

Habit: Slender, erect-ascending (rarely decumbent), annual and biennial herbs

Flowering: May-September (in NY)

Fruiting: June-October

General Distribution: New Brunswick and Quebec to British Columbia, south to Mexico and

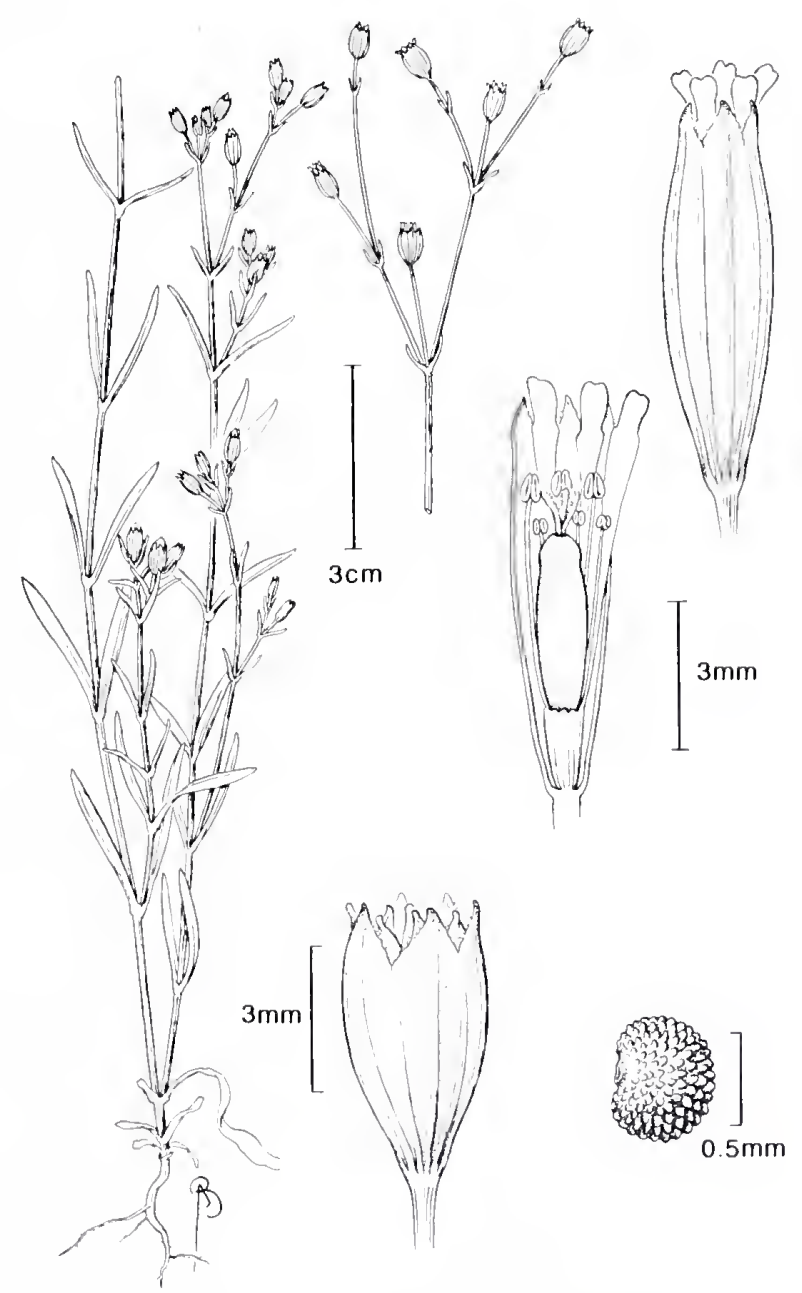
South America (naturalized elsewhere)

Description: Plants with bisexual flowers; stigmas 3, pale, ca. $1.3 \mathrm{~mm}$ long, ciliate; styles 3, ca. $1.5 \mathrm{~mm}$ long, free; ovary 1, ovoid, ca. $3 \mathrm{~mm}$ long, $2 \mathrm{~mm}$ broad, borne on a short androgynophore, the 6 valves forming a pale valvate cap, the apex of the olive-green ovary nearly completely 3 -chambered; fruit an elliptic to ovoid capsule, (3) 6-8 (10) mm long, (2) 3-4 (5.5) mm broad, smooth, olive to tan, opening by 6 short, triangular valves and closely invested within the persistent calyx, from which it is often slightly exserted upon dehiscence; carpophore 
ca. $1.5 \mathrm{~mm}$ long; seeds many, 0.6-0.7 mm long, plump, reniform, the surfaces charcoal gray (somewhat glaucous) to dark, glossy brown, covered with sharp tubercules; stamens 10; anthers oblong, dorsifixed, golden or pale; filaments very slender, 6-9 mm long; perianth of 2 whorls, or petals lacking; petals (0-) 5, free, not showy, 2-12 (16) $\mathrm{mm}$ long, often less than $1 \mathrm{~mm}$ broad, linear and poorly differentiated into claw and limb or spatulate, the limb, when expanded, usually less than $2 \mathrm{~mm}$ broad, bifid or entire, (or limbs sometimes linear, arched or twisted), coronal scales lacking or obscure, petals pink to roseate with pink, rosy, dark red, purplish or white tips; sepals 5 , the calyx lobes $0.9-1.7 \mathrm{~mm}$ long and broad, obtuse to acute, usually reddish-purple, at least along the ciliate margins, calyx tube cylindric in early flower, becoming fusiform, urceolate, persistent and closely conforming to the elliptic to ovoid capsule in fruit, 4.0-9.7 mm long, 2.3-4.5 (5.6) mm broad, with 10 prominent veins that extend to the pedicel, surface smooth, shiny green, glabrous; pedicels very slender, ribbed, at least above, 3-30 (36) mm long, glabrous; inflorescence a many-flowered panicle, a series of axillary and terminal clusters (or single flowers); bracts of the inflorescence paired, linear to lanceolate, 1-6 (9) mm long, pale green often with purplish tips and entire, ciliate margins (rarely bifid); cauline leaves paired, linear to broadly lance-elliptic or oblanceolate, mostly $1-5(7) \mathrm{cm}$ long, 0.2-1.5 (2) cm broad, usually puberulent, at least along the veins and the entire margins, tips acute to acuminate, bases connate or incompletely so, clasping the node with villous hairs along the margin of their juncture; basal leaves similar, or up to $9 \mathrm{~cm}$ and obovate to spatulate; petioles absent; stipules absent; stems erect, ascending or lax, up to $80 \mathrm{~cm}$ long or tall, solitary or more often branched above, ribbed and channeled, irregularly short-puberulent and usually with golden to dark glutinous zones, up to several $\mathrm{cm}$ long on the internodes, their sticky excretions associated with a few longer hairs and soft glandular tissues; root system an annual or biennial taproot $(2 n=24)$.

Infraspecific Variation: Petals are sometimes abortive or totally lacking. Petal tips may be entire or emarginate, and the several flower colors include bicolored variants. These traits have been used to distinguish varieties and forms that seem to lack geographic or taxonomic significance.

Importance: Although this species is considered native over a broad geographic range in the Americas, it is an aggressive weed, often associated with disturbance. Its distribution range may have expanded significantly with the advent of the migration of mankind into the New World. 


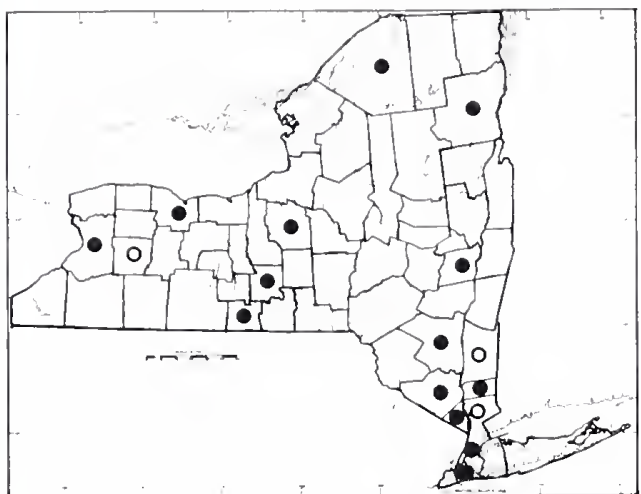

4. Silene cserii Baumg.

Common Names: Campion

Type Description: Baumgarten, Enum. Stirp. Transs. vol. 3, p. 345,1816

Synonyms: $S$. cserei, $S$. czerei and $S$. czerii of authors, S. fabaria sensu Rydb., not (L.) Sibth. \& Sm.

Origin: Native to southeastern Europe

IIabitats: Disturbed ground, roadsides, quarries, particularly widespread along railways

ILabit: Erect or ascending biennial herbs

Flowering: Late May-September

Fruiting: June-November

General Distribution: Quebec to British Columbia, Montana, Indiana, Missouri, Ohio and southern Pennsylvania

Description: Plants with bisexual flowers; stigmas (1-) $3-5(-8)$, the ciliate receptive line prominent expanded at the reddish-purple, somewhat flat-

tened stigmatic tips of the styles; styles (2) 3-5 (-8), linear 10-15 (17) mm long, sometimes branched at tips; ovary 1, fusiforme, borne on a minutely pubescent gynophore, ca. $1 \mathrm{~mm}$ long; fruit an ovoid capsule, $8-13 \mathrm{~mm}$ long, 5-8 $\mathrm{mm}$ broad, tan, smooth and glossy, dehiscing by 6 narrowly acuminate valves 1-2 $\mathrm{mm}$ long that are only slightly reflexed and exserted from the flower after dehiscence; carpophore 0.9-1.6 mm long, minutely woolly-puberulent; seeds many, 0.8-1.0 mm long, triangular in outline to comma-shaped with concave sides, golden brown to chocolate, the surfaces strongly papillate, sometimes with stalked papillae; stamens 10; anthers linear-ovate, ca. $1.5 \mathrm{~mm}$ long, dorsifixed, golden; filaments linear, pale, up to $2 \mathrm{~cm}$ long; perianth of 2 whorls; petals 10-15 (18) $\mathrm{mm}$ long, white to creamy, claw mostly less than $1 \mathrm{~mm}$ broad, flared at the tip into a narrow, bilobed limb 4-5 mm long lobes 1-2 (3) $\mathrm{mm}$ long, obtuse at the tips, coronal scales obscure or lacking; sepals 5, calyx lobes deltoid, 1-2 mm long and broad, often ciliate-tufted at apex, calyx tube cylindric, becoming fusiform, $7-11 \mathrm{~mm}$ long, up to $8.2 \mathrm{~mm}$ broad inflating only to the dimensions of the mature fruit and closely investing it, tube surface green becoming pale, yellowish, glabrous, main veins ca. 20, 10 long and 10 short, sometimes dichotomously branching, but not strongly reticulate-anastomosing; pedicels glabrous, terete to ribbed, $5-25 \mathrm{~mm}$ long; inflorescence a narrow, raceme-like panicle (often a dichotomously branched pair), 7-30 (40) cm long, bearing up to 50 flowers; bracts of the inflorescence lanceolate, up to $6 \mathrm{~mm}$ long, often ciliate-margined; leaves $3-8(10) \mathrm{cm}$ long, 0.6-3.0 (3.8) $\mathrm{cm}$ broad, narrowly oblong to broadly ovate, acute to cuspidate, with connate-perfoliate bases (except basal leaves, which are more attenuate), margins entire, surfaces glabrous, somewhat glaucous; stipules absent; stems robust, erect, often grooved, green to yellowgreen, glabrous, not conspicuously swollen at the nodes, up to $60(75) \mathrm{cm}$ tall; root system a thick, tough biennial taproot, pale in color, often contorted, with thick, lateral branches $(2 n=24)$. 
Infraspecific Variation: A biennial member of an extremely variable species complex of Eurasia. In Europe S. cserii is sometimes confused with S. fabaria (L.) Sibth. \& Sm., which is said to differ from it in having succulent, smaller leaves, borne more basally, acute calyx lobes and only 10 main calyx veins. Plants approaching this condition occur in New York State, but inconsistency of characters prompts the recognition of a single species for the purposes of this flora.

Importance: A weed, primarily of railroad beds and waste places.

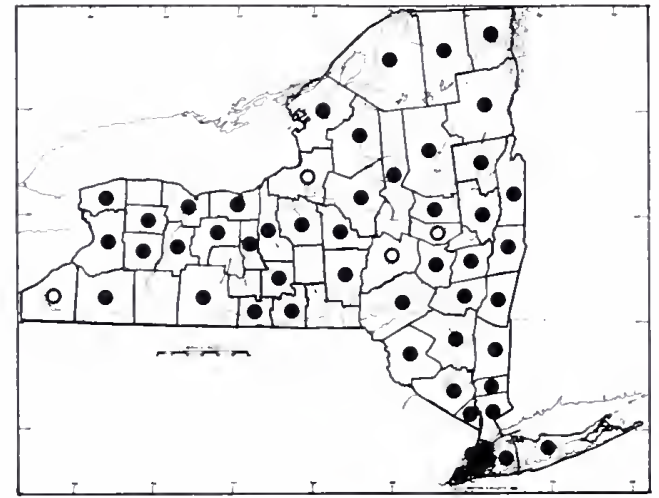

5. Silene vulgaris (Moench) Garcke

Common Names: Bladder Campion, Maiden's-tears Type Description: Moench, Fl. Nord Mittle-

Deutch., ed. 9, p. 64, 1869

Synonyms: Behen vulgaris Moench, Cucubalus behen L., C. inflatus Salisb., C. latifolius Mill., $S$. cucubalus Wibel, S. inflata (Salisb.) Sm., S. latifolia (Mill.) Britten \& Rendle, not Poir., $S$. venosa (Gilib.) Aschers, a nomen illeg.

Origin: A native of Europe and eastern Asia

Habitats: A wide range of disturbed habitats, including roadsides, pastures and gardens, but also in less disturbed meadows, thickets and open forests

IIabit: Sprawling-decumbent to erect perennial herbs

Flowering: April-November

Fruiting: June-December

General Distribution: Naturalized from Nova Scotia to British Columbia, scattered southward to southern California, Colorado, Arkansas and Georgia

Description: Plants with bisexual flowers; stigmas 3, papillose, filiform; styles 3, filiform, 12-20 (28) $\mathrm{mm}$ long, the tips sometimes recurved, free to their point of attachment on a pale valvate cap; ovary 1, ovoid, green, ca. $3 \mathrm{~mm}$ long, $1.5 \mathrm{~mm}$ broad, borne on a glabrous androgynophore (1.4-) 1.9-3.5 mm long; fruit a shiny, olive to tan, ovoid to oblong capsule, partially to fully 3-chambered, 7-9 (11) $\mathrm{mm}$ long, $6-8 \mathrm{~mm}$ broad, the teeth deltoid, $1 \mathrm{~mm}$ or less, acute, not strongly reflexed or exserted on dehiscence; carpophore glabrous, somewhat fluted, (1.4-) 2.0-3.8 mm long; seeds many, irregularly triangular to comma-shaped with 1 or 2 concave sides, 0.9-1.4 (2) $\mathrm{mm}$ long, dark brown, the edges and surfaces variably rugose to prominently papillose; stamens 10; anthers ca. $2 \mathrm{~mm}$ long, $0.5 \mathrm{~mm}$ broad, golden, dorsifixed; filaments slender, 9-15 (18) mm long; perianth of 2 whorls; petals 5 , white (or pink tinged), the claw 6-13 $\mathrm{mm}$ long, linear below, expanded into auricles near the mouth of the calyx tube, the limb 5-8 (10) $\mathrm{mm}$ long, $3-5 \mathrm{~mm}$ broad, usually deeply cleft into 2 obtuse lobes, coronal scales absent or much reduced; sepals 5, broadly deltoid, $2.3 \mathrm{~mm}$ long, $2-4 \mathrm{~mm}$ broad, acute to slightly apiculate, margins ciliate, at least toward the tips, calyx tube cylindric to ovate in flower, becoming inflated, campanulate to broadly urceolate, $10-16$ (20) $\mathrm{mm}$ long, 6-12 (14) $\mathrm{mm}$ broad, somewhat membranaceous, 
loosely enclosing the capsule in fruit, the surface glabrous, greenish to yellowish or tan, often with a purple blush (or chalky), veins becoming strongly reticulate and slightly raised; pedicels slender, 3-15 (25) mm long, terete or angled, glabrous or puberulent; peduncle like the pedicels, up $104 \mathrm{~cm}$ long; inflorescences open dichasia at branch tips, usually several per plant with 3-20 (30) flowers each; inflorescence bracts paired, pale, membranaceous, at least on the margins, ovate to lanceolate, $2-3 \mathrm{~mm}$ long, entire and glabrous or ciliate; leaves opposite, (linear) lanceolate to broadly elliptic or ovate, entire, 1.5-7.5 (9) cm long, 0.3-2.0 (3.6) cm broad, surfaces glabrous, punctate, margins glabrous or hirsutulous, the tips acuminate to obtuse-apiculate, bases broadly rounded to tapered or attenuate into poorly defined petioles; stipules absent; stems decumbent to ascending, tough, only slightly swollen at the nodes, internodes often grooved, glabrous or sparsely puberulent, greenish turning tan or reddish, up to a meter tall, the base a tough, perennial caudex, stolon or rhizome bearing a fibrous root system that is largely adventitious $(2 n=24,48)$.

Infraspecific Variation: Silene vulgaris is a polymorphic species with a number of named varieties. Biosystematic studies of this species in the European flora revealed at least 15 "life forms" (Aeschimann, 1985). The plants differ in floral morphology, including stipe length, calyx size and presence or absence of welldeveloped coronal scales. They may also be stoloniferous, rhizomatous, decumbent or erect. Bract shape and texture also vary, and different varieties and races show extremes, ranging from small, petioled, mostly basal, linear-lanceolate leaves to large, clasping, mostly cauline, ovate ones. Two statistically distinct seed morphologies have also been reported for the species. It is likely that both diploids and tetraploids are found in New York State, since the morphological spectrum described for Europe is well represented by naturalized plants here.

Importance: A prolific weed of disturbed ground, and an occasional pest in gardens.

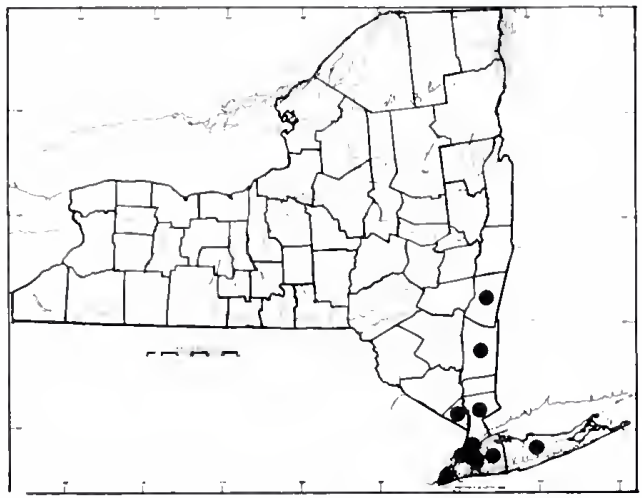

6. Silene caroliniana Walt.

Common Names: Wild Pink, Common Pink, Carolina Pink

Type Description: Walter, Fl. Carol., p. 142, 1788 Synonyms: Melandrium pensylvanicum (Michx.) Rohrb., S. caroliniana ssp. pensylvanica (Michx.) Clausen, S. caroliniana: ssp. wherryi (Small) Fern.; var. pensylvanica (Michx.) Fern.; var. wheryi (Small) Fern., S. pensylvanica Michx., $S$. wherryi Small

Origin: Native to eastern North America

Ilabitats: Dry, often sandy soils, fields banks or cliffs in full sun or partial shade of open woods

Iabit: Cespitose, perennial herbs

Flowering: April-June

Fruiting: May-August

General Distribution: Southern New Hampshire, southeastern New York and southern Ontario to Missouri, south to Alabama and South

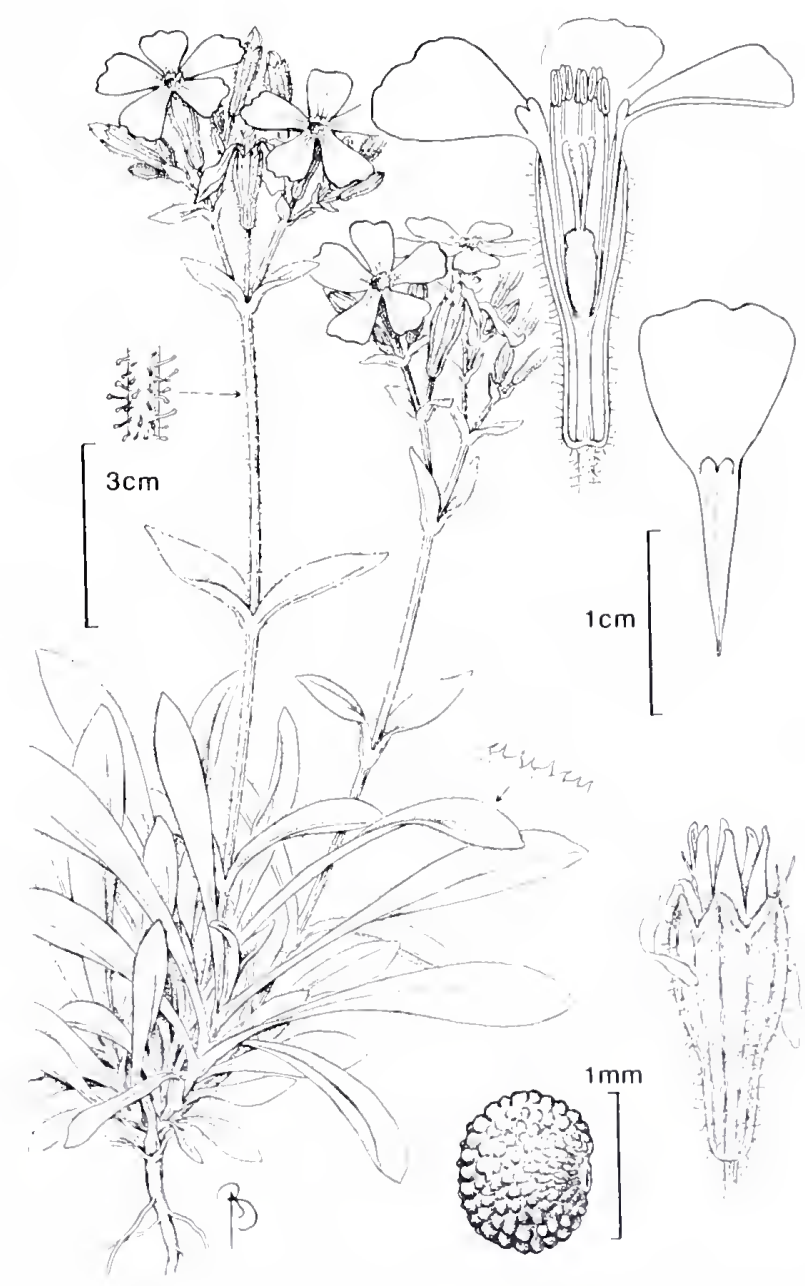


Carolina. Ours is so-called var. pensylvanica, which occurs mostly in the northern end of the range, then sporadically south to Tennessee and North Carolina

Rarity Status: This species is protected from exploitation by New York State law, but it is not listed by NYNHP in their rare plant status list. It is historically known from about 15 locations on Long Island and in the New York city boroughs, with 10 populations recorded northward to the southern Taconic range. Since a number of these populations are possibly extirpated, the species may be far rarer in the State than its current rank would suggest.

Description: Plants with bisexual flowers; stigmas 3, papillose zones ca. $1.5 \mathrm{~mm}$ along the style tips; styles 3 , filiform, 6-10 mm long, free; ovary 1, the valvate cap ovate-hemispherical, 1.5-3.0 mm long, distinct from the ovary wall below, the ovary (below the cap) 3-6 $\mathrm{mm}$ long, hemispheric to broadly cylindric, borne on an androgynophore 5-9 $\mathrm{mm}$ long; fruit an ovoid to cylindric capsule, $9.13 \mathrm{~mm}$ long, $5-8 \mathrm{~mm}$ broad, dehiscing in the upper third by 6 golden-brown, leathery, lanceolate teeth, 3-4 mm long, the lower capsule thinner-walled, glossy, greenish to tan; carpophore stout, fluited, 5-8 mm long; seeds brown, 1.3-1.5 mm long, tuberculate, ovoid; stamens 10; anthers linear, 1.1-1.5 mm long, golden; filaments slender, free above the androgynophore, 9-16 m long; perianth of 2 whorls; petals 5, pale pink to rosy or white, the distinct claw 7-14 (17) $\mathrm{mm}$ long, included to slightly exceeding the calyx, ciliate-margined, the limb showy, often diverging at a right angle, 5-14 (18) $\mathrm{mm}$ long, 3-12 mm broad, rounded to somewhat truncate at tip, entire or only slightly erose (less often emarginate or notched), coronal scales well-developed, colored like the petals, with 2 lobes, 2-3 mm long, ca. $1 \mathrm{~mm}$ broad; sepals 5 , acute to bluntly deltoid, $1-3 \mathrm{~mm}$ long, $1-2 \mathrm{~mm}$ broad, greenish to purple, or with hyaline margins, glandular-hispid, the calyx tube (0.6) $1-2(2.4) \mathrm{cm}$ long, tapering upward from a slender base, turbinate or (in ours) cylindric, green below to rosy or deep purple above, short glandular-hispid, the 10 major veins somewhat raised; pedicels (glandular) hispid, 1-8 (14) $\mathrm{mm}$ long (or individual flowers may be sessile); peduncles like the pedicels, but up to $4 \mathrm{~cm}$ long; inflorescence of terminal clusters of relatively dense, showy, few-flowered cymes; bracts linear to ovate, leaf-like, glandular-pubescent to almost glabrous, less than $1 \mathrm{~cm}$ long; leaves paired on the flowering stems, but mostly in dense, cespitose, basal tufts; cauline leaves linear to broadly lanceolate, ovate or oblanceolate, one pair subtending the terminal inflorescence and usually 1-2 pairs (rarely 3) below, linear to lanceolate or oblanceolate 0.8-3.5 (5) $\mathrm{cm}$ long, 1-7 $\mathrm{mm}$ broad, perfoliate-clasping to indistinctly petioled, tips acute to obtuse, entire, ours glandular-hispid, especially along the entire margins; basal leaves numerous, tufted, (lanceolate) oblanceolate to spatulate, $1-11 \mathrm{~cm}$ long, 2-16 (20) $\mathrm{mm}$ broad at the widest point, both surfaces (in ours) glabrous, the tips acute to obtuse or apiculate, margins entire, ciliate, the bases long-attenuate into indistinct petioles; stipules absent; flowering stems glandular- hispid or merely short-hispid above, 2-20 (32) cm tall, spreading, ascending or erect, from cespitose, basal tufts, branching at or near ground level from an erect or ascending, woody caudex up to $1 \mathrm{~cm}$ in diameter (sometimes spirally twisted), and lateral rhizome system; root system fibrous $(2 \mathrm{n}=48)$.

Infraspecific Variation and Iybridization: Three infraspecific taxa are often recognized, either at the varietal or subspecies level, but these are far from well-differentiated, and intergrade, especially in the southern part of the distribution range of the species. In plants of the north, often called $S$. caroliniana var. pensylvanica, the calyx tube is slender, narrowing further toward the base, the plants are copiously glandular-hispid (except for basal-leaf surfaces), petal claws slightly exceed the calyx tube, and flowering stems may reach heights up to 30 $\mathrm{cm}$. In so-called var. wherryi, plants are shorter, mostly clothed with eglandular hairs on the upper stems and the calyx, which is broader, more evenly tubular and not exceeded by the petal claws. Other characters, (e.g., cauline leaf shape) have also been cited in making infraspecific distinctions; however, plants studied in preparation for this publication showed a broad range of variability, and geographic correlations seemed far less obvious than indicated in the literature. Silene caroliniana is known to hybridize naturally with $S$. virginica L., the scarlet catchfly, in the southern Piedmont (Mitchell \& Uttal, 1968). The hybrids are taller than typical plants of the wild pink, with narrower, darker pink, notched petals; thus, the cleft petals more common in southern populations may have been derived through introgression.

Importance: Wild pink is widely grown ornamentally in moderate climates, especially in open, sandy places and rock gardens. Its cespitose habit and dense clusters of showy, pale pink, salmon or white flowers make it a horticultural favorite. 


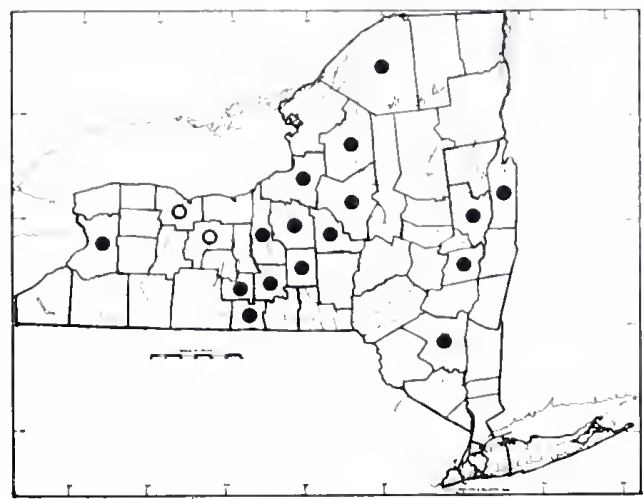

7. Silene dichotoma Ehrh.

Common Names: Forked Catchfly, Forking Catchfly

Type Description: J. Ehrhart, Beitr. 7, p. 143, 1792

Synonyms: $S$. anglica and $S$. gallica of NY authors, not L., $S$. racemosa Otth in DC.

Origin: A native of Eurasia

Habitats: Roadsides, fields, lake shores and waste places

IJabit: Robust, erect or ascending, annual herbs

Flowering: June-September

Fruiting: June-November

General Distribution: Of sporadic, weedy distribution from southern Quebec to British Columbia, south to California, the Carolinas and Georgia (Texas)

Description: Plants with bisexual flowers or polygamomonoecious; stigmas 3 , papillose zones on the style branches; styles 3, filamentous, pale, 7-14 (16)

$\mathrm{mm}$ long; ovary 1, fusiform-cylindric, ca. $5 \mathrm{~mm}$ long, $1 \mathrm{~mm}$ broad, borne on a smooth androgynophore ca. 2 $\mathrm{mm}$ long; fruit an ovoid capsule, $6-8 \mathrm{~mm}$ long, $4-6 \mathrm{~mm}$ broad, smooth, greenish-tan, dehiscing by 6 short, acute valves; carpophore, stout, 1.8-2.8 (3.7) mm long, glabrous, fluted; seeds 1.1-1.4 mm long, comma-shaped with indented sides, shallowly indented along the dorsal margin, dark brown, prominently rugose-papillose; stamens 10; anthers 1.5-2.5 mm long, golden, dorsifixed; filaments slender, (4-) 9-17 mm long; perianth of 2 whorls of 5; petals 5, white (rarely pinkish), the claw slender, tapering toward base from about $1 \mathrm{~mm}$ in width at summit, the limb 6-8 mm long, 3-4 mm broad, tips obtuse, shallowly to deeply bilobed (entire or minutely erose), coronal appendages $\mathrm{ca} .1 \mathrm{~mm}$ long and broad, colored like the petals; sepals 5, acute, 1-2 $\mathrm{mm}$ long, with minutely woolly-fringed margins, calyx tube slenderly tubular-cylindric in flower, $0.9-1.7 \mathrm{~mm}$ long, $3-5 \mathrm{~mm}$ broad, becoming elliptic to fusiform, up to $6.3 \mathrm{~mm}$ broad, not inflated, closely conforming to the fruit, surfaces minutely villous between veins, coarsely hispid (with jointed trichomes) along the 10 prominent veins; pedicels short-hispid, up to 2 (3) $\mathrm{mm}$ long or often very short, the flowers subsessile; the inflorescences are spike-like monochasial cymes, borne in terminal pairs, sometimes in upper leaf axils as well, flowers oriented laterally or slightly drooping, but becoming appressed upward and ascending in fruit; bracts paired, with ciliate margins and veins, grading from green, linear, leaf-like structures in the lower inflorescence to obovate, scarious floral bracts above, upper bracts 3-6 mm long, 1-4 mm broad; leaves paired at the \pm swollen, jointed nodes, linearlanceolate to oblanceolate, elliptic or obovate, 1-6 (8) cm long, 3-35 (40) mm broad, margins entire, hispid to villous, lamina often prominently 3 -veined, the surfaces puberulent to hispid (or densely villous), tips (acuminate) acute to obtuse-apiculate, bases long-attenuate into indistinct, clasping petioles; stipules absent; stems terete to deeply grooved, tough, up to $1 \mathrm{~cm}$ in diameter below, yellow-green to deep reddish-brown 
toward the base, puberulent to retrorsely villous or hispid, erect-ascending up to $1.2(1.6) \mathrm{m}$; root system a stout, annual taproot with strong lateral branches $(2 n=24)$.

Infraspecific Variation: Densely gray-pubescent plants with tufted basal rosettes of leaves and deeply cleft petals are called ssp. racemosa (Otth in DC.) Gräbn. A few specimens from New York fit this category. American authors have shown considerable inconsistency in treating $S$. dichotoma, often confusing it with $S$. gallica $\mathrm{L}$. There are conflicting statements as to whether the petals are entire, notched or deeply bifid, and this character is sometimes used in keys, perhaps unwisely, since it seems variable (at least in weedy North American materials). In Europe, where the diversity of characters and species is much greater within the genus, $S$. dichotoma is separated from $S$. gallica on the basis of its glabrous, longer carpophore and seeds over $1 \mathrm{~mm}$ long.

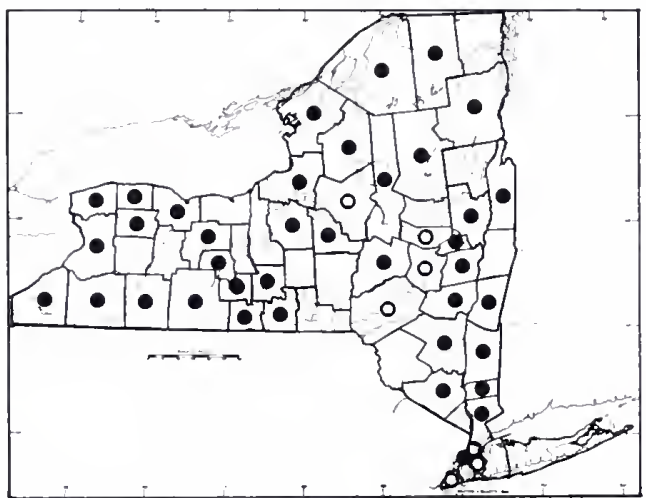

\section{Silene noctiflora $\mathrm{L}$.}

Common Names: Night-flowering Catchfly or Campion, Sticky Campion or Cockle

Type Description: Linnaeus, Species Pl. I, p. 419, 1753

Synonym: Melandrium noctiflorum (L.) Fries

Origin: A native of Eurasia

Habitats: Cultivated fields, pastures, roadsides, waste places, meadows, clearings, often in dry, sandy or rocky soils

Ilabit: Erect, annual (or winter-annual) herbs

Flowering: June-September (night-flowering)

Fruiting: July-December

General Distribution: Sporadic, from Newfoundland to the Yukon, south to California and Louisiana

Description: Plants with bisexual flowers (opening primarily at night); stigmas 3 (4), papillose, somewhat flattened; styles 3 (4), 4-8 mm long, linear; ovary 1, ovate, borne on an androgynophore, ca. $1 \mathrm{~mm}$ long; fruit an ovoid capsule, 1.4-1.9 (2.3) mm long, 7-12 $\mathrm{mm}$ broad, the surface tan, glossy, dehiscing at the apex by $6(-8)$ acute, moderately reflexed valves $2-3 \mathrm{~mm}$ long, borne on a stout carpophore 1-2 (3) mm long; seeds $1.0-1.3 \mathrm{~mm}$ long, ca. $1 \mathrm{~mm}$ broad, plump, ovoidlenticular or trapezoidal and shallowly indented on the sides and dorsal surface, brown turning dark graybrown, the blunt tuberculae with darker tips; stamens 10; anthers golden, dorsifixed, 1.6-1.8 mm long, ca. 0.8 $\mathrm{mm}$ broad; filaments $1.6-2.5 \mathrm{~mm}$ long, linear; perianth of 2 whorls; petals 5 , white, pink or creamy-yellow tinged, the pale claw 1.7-2.2 (2.8) mm long, slightly exceeding the calyx tube, ca. $1 \mathrm{~mm}$ broad below, flared above into lateral auricles ca. $1 \mathrm{~mm}$ long and broad, the petal limb 6-10 (14) mm long when expanded (only in pale light or darkness) creamy at base, pinkish-tinged toward the narrowly-rounded, deeply-bifid tips, ligulate, with 2 short, coronal appendages at the limb/claw juncture; sepals 5, the lobes 3-8 (11) $\mathrm{mm}$ long, linear-cuspidate, viscid, glandular and abaxially hispid, adaxially minutely woolly, the margins often hyaline, 
calyx tube cylindric in flower, tapering toward the tip, becoming fusiform and constricted above the developing fruit, and finally ovate, closely conforming to the outline of the mature fruit and almost equalling it, 0.9-2.2 $\mathrm{mm}$ long, $7-13 \mathrm{~mm}$ broad, 10-veined, the veins prominent, glandular-hispid, green with pale, whitish to hyaline zones between them that are largely glabrous; pedicels stout, (2) 5-12 (28) mm long, hispid and glandularpubescent; inflorescences terminal (sometimes paired) cymes (dichasia), often of several 3-flowered units; bracts green, linear to lanceolate, glandular and hispid, $2-8 \mathrm{~mm}$ long subtending the flowers, up to $2.5 \mathrm{~cm}$ subtending the inflorescence; leaves (linear) lanceolate, lance-elliptic or oblanceolate to broadly ovate, obovate or spatulate, 2-12 (14) cm long, 0.4-5.5 (7) cm broad, strongly 3- to 5-veined from the base, strongly glandularhispid to weakly strigose, margins entire, tips acuminate to acute or obtuse-apiculate, bases obtuse, acute or narrowly attenuated into petioles, especially on basal rosette leaves (when present); stipules absent; stems stout, terete to strongly grooved, glandular and hispid throughout, up to $60(90) \mathrm{cm}$ tall; root system a stout, annual taproot with strong, lateral branches $(2 n=24)$.

Infraspecific Variation and IIybridization: Plants of this species are sometimes confused with the white campion ( $S$. latifolia Poir.), but they may usually be distinguished by their linear-caudate calyx lobes, 3 styles and 6-valved capsules; however, a few New York specimens were found that seem to represent intermediates. These plants have intermediate length calyx lobes that are not strongly viscous, 4 styles and 7-9 capsule valves. Attempts to produce hybrids between these two species in the greenhouse have been unsuccessful (Prentice, 1978), and a reported cross of $S$. noctiflora and $S$. dioica $\mathrm{L}$. is also suspect according to McNeill (1980a).

Importance: Night-flowering catchfly is a weed of grain, alfalfa, bean and mustard fields, reaching detrimental population densities in some areas of Canada and northern Europe. In areas where it is a noxious weed, it has also been found to be resistant to 2,4-D and other widely-used herbicides.

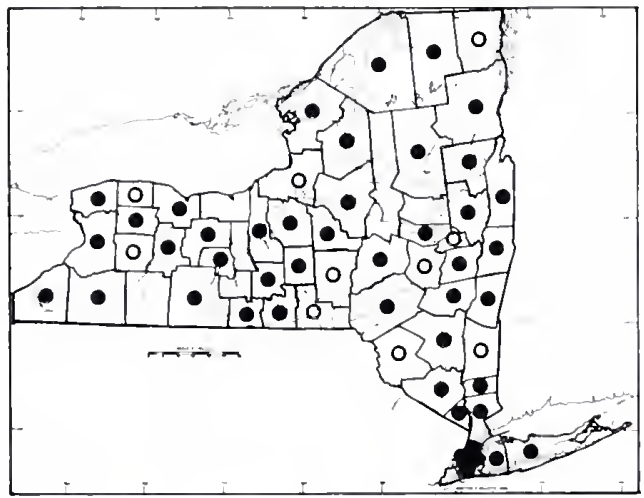

\section{Silene latifolia Poir.} ssp. alba (Mill.) Greuter \& Burdet

Common Names: White Campion, White Cockle, White-robin, Evening Campion or Lychnis, Snake-flower, Cuckoo-flower, Thunder-flower, Bullrattle

Type Description: Poiret, Bot. Barb. ii, p. 165, 1789

Note: To avoid confusion, some authors may wish to list this species as:

S. latifolia Poir. non (Mill.) Britt. \& Rendle

Synonyms: Lychnis alba Mill., L. anensis Gacrtn., Meyer \& Scherb., L. vespertina Sibth., Melandrium album (Mill.) Garcke, M. dioicum ssp. album (Mill.) D. Löve, S. alba (Mill.) Krause in Sturm, not Muhl. ex Britt., S. pratensis (Rafn) Godr. \& Gren., not Poir.

Origin: A native of Eurasia

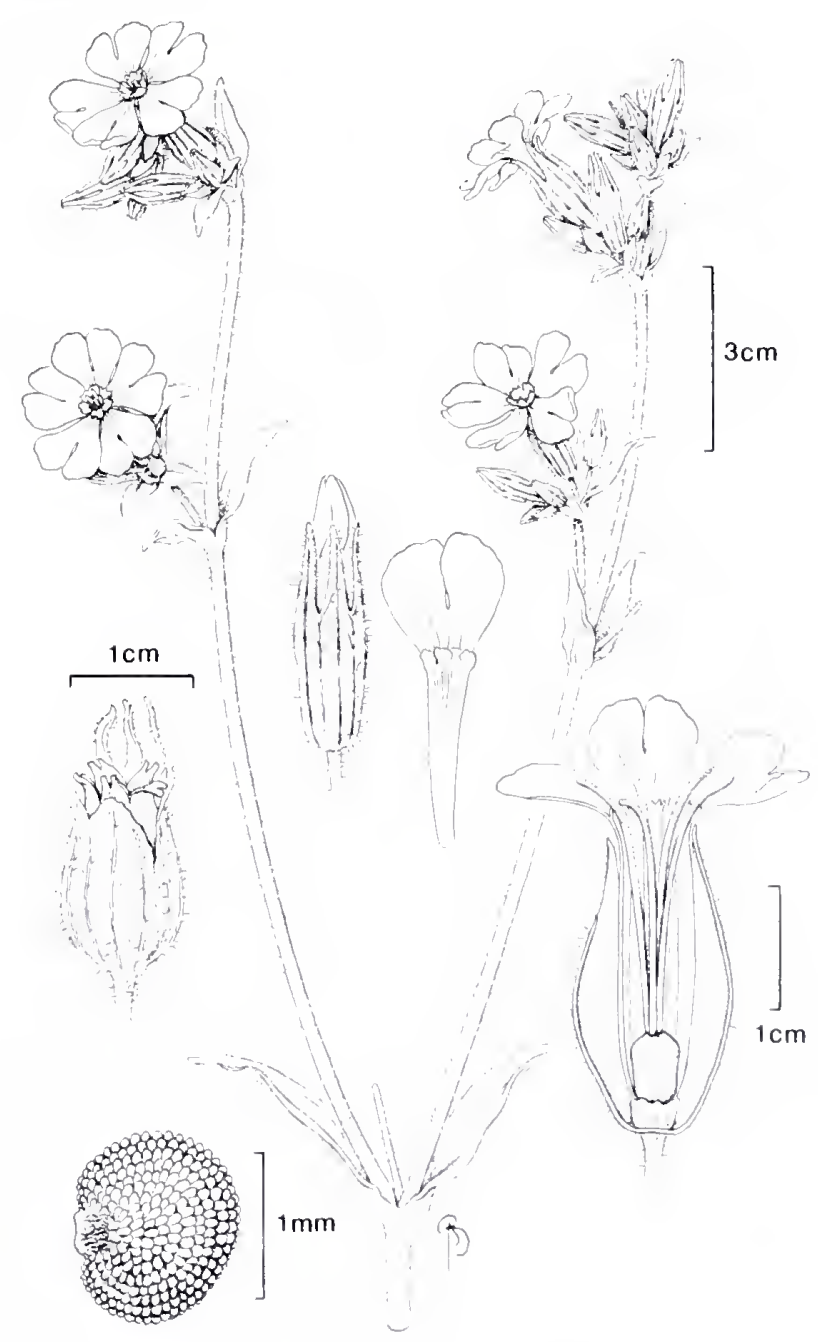


Habitats: Fields, ditches, roadsides, urban streets and waste places, cultivated fields, meadows, thickets, borders and open woods; a ubiquitous weed

Ilabit: Erect or ascending, often much-branched, biennial or short-lived perennial herbs

Flowering: Late May-October

Fruiting: June-November

General Distribution: (Greenland) Nova Scotia and Quebec to British Columbia and Alaska, south to California, Illinois, Arkansas and Georgia

Description: Plants dioecious; stigmas (4) 5, densely papillose zones on the upper halves of the styles; styles (4) 5, linear, pale, 10-17 mm long; ovary smooth, green ovoid, ca. $4 \mathrm{~mm}$ long, $3 \mathrm{~mm}$ broad, subsessile; fruit a glossy, golden-brown capsule 1.4-1.9 (2.2) cm long, 1.0-1.5 (1.8) cm broad, ovoid, subsessile, virtually filling the calyx tube at maturity and equal in length to slightly exserted, dehiscing by (8-) 10 acute teeth $1-3 \mathrm{~mm}$ long that are erect or moderately recurved; seeds plump or with concave sides, 1.1-1.3 mm long, brown with obtuse to acute tubercles; stamens 10; anthers creamy, linear, ca. $1.5 \mathrm{~mm}$ long; filaments slender, 1.4-2.3 cm long; perianth of 2 whorls; petals white (or pink-tinged), claw $1-2 \mathrm{~cm}$ long in male flowers, up to $3 \mathrm{~cm}$ in females, slender, auriculate, not strongly exserted, petal limb $0.8-1.6 \mathrm{~cm}$ long, ca. half as broad, bifid with obtuse lobes; sepals 5, lobes obtuse to acute (acuminate) ovate to lanceolate, 3-8 (10) $\mathrm{mm}$ long, short-hispid, often glandular pubescent, usually with a strong, central vein, calyx tube (female flowers): 1.8-2.5 (3) cm long, ovate-cylindric becoming ovoid in fruit, up to $1.7 \mathrm{~cm}$ broad, veins up to 20, (male flowers): tube cylindric to narrowly ovoid, 0.8-2.1 cm long, 3-7 mm broad, hispid and often glandular-pubescent, usually 10-veined; pedicels 1-16 (30) mm long, those on solitary or axillary flowers usually substantially longer, sparsely to densely hispid, often glandular-pubescent; inflorescence a few to many-flowered dichasium, much branched on the male plants with copious clustered bracts; inflorescence bracts leaf-like, up to $3 \mathrm{~cm}$ long, those directly subtending the flowers deltoid to ovate, acute, 1-6 mm, mostly 2-4 times as long as broad, hispid, often glandular; cauline leaves lanceolate to broadly elliptic or obovate with acute to acuminate (rarely obtuse) tips and rounded to attenuated clasping bases, 2-9 (11) $\mathrm{cm}$ long, 0.5-2.5 (3) $\mathrm{cm}$ broad, entire, pustulate-puberulent to short-scabrous or downy-hispid when young; basal leaves of the first year rosette similar to cauline leaves but often obovate with more attenuated bases; petioles absent or some leaf bases long attenuated; stipules absent; stems terete or grooved, hispid, often glandular-pubescent, particularly above, up to $8 \mathrm{dm}(1 \mathrm{~m})$ tall, branching sparingly in female plants, but sometimes profusely in the males; root system a tough, biennial (rarely annual or perennial) taproot or twisted semi-erect rootstock $(2 n=24)$.

Infraspecific Variation and IIybridization: Although they have sometimes been placed in separate genera, Silene noctiflora and S. latifolia (often called Lychnis alba) have parallel morphology, even though they have been placed in different sections of the genus; they have the same chromosome number; however, greenhouse attempts at crossing them have failed. Seed characters are usually distinctive, while other commonly cited morphological differences, such as glandularity, bract shape and flower color prove less reliable in distinguishing these taxa. Style and capsule tooth numbers are directly linked with sexually dimorphic versus bisexual flowers, and have been afforded great significance by some authors. Dioecious, day- and eveningflowering plants of this species complex (e.g., S. latifolia and S. dioica in our area) have 5 styles and \pm 10 capsule teeth, while late-evening and night-flowering $S$. noctiflora plants have bisexual flowers with 3 styles and 6 capsule teeth. This is not a clearcut distinction, however, since plants of intermediate morphology have been noted in which the style number is 4 , and capsule teeth number 7-9. Capsule teeth also often bear sutures in excess of the number expected for the species, and when these become involved in dehiscence, the exercise of counting teeth becomes suspect. To further complicate matters, putative Silene dioica $x$ latifolia hybrids have been reported, both in Europe and within our range in New York State. Occasional pink flower color in white campion and white-flowered sports of the red campion also serve to confuse the picture.

Importance: This species can be a noxious weed of crop fields. 


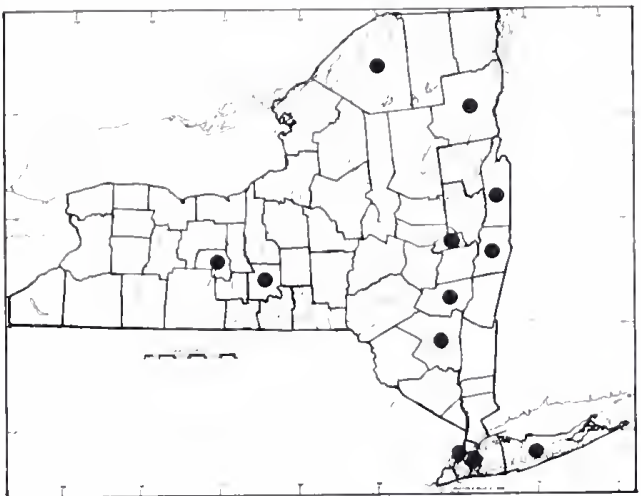

10. Silene dioica (L.) Clairv.

Common Names: Red Campion, Red Bird's-eye, Red-robins, Soldiers, Adder's-flower, Devil'sflower

Type Description: Linnacus, Species P1. I., p. 437, 1753

Synonyms: Lychnis dioica L., L. diurna Sibth., Melandrium dioicum (L.) Coss \& Germ., $M$. rubrum (L.) Garcke

Origin: A native of Eurasia

Habitats: Cultivated fields, roadsides, gardens, waste places, meadows and borders

Habit: Spreading to erect, perennial herbs (sometimes biennial or short-lived)

Flowering: Late May-October

Fruiting: June-November

General Distribution: Sporadically, but widely scattered from Newfoundland to British Colum-

bia, south to Oregon, Indiana and Delaware

Distribution Note: McNeill (1978) expressed doubt that this species still occurred in eastern North America, but it was collected or reported at five locations on eastern Long Island (Suffolk Co.) as late as 1964-67.

Description: Plants dioecious; stigmas 5, papillose; styles 5, slender, pale, $8-13 \mathrm{~mm}$ long; ovary spherical, subsessile, ca. $3 \mathrm{~mm}$ in diameter; fruit a globose to broadly ovate, glossy, tan capsule, $9-15 \mathrm{~mm}$ long and broad, dehiscing by \pm 10 strongly recurved teeth $3-4 \mathrm{~mm}$ long, often splitting further to form a gaping aperture and stretching the mouth of the calyx tube; seeds ca. $1 \mathrm{~mm}$ long and broad, plump with slightly concave side, brown with uniformly colored tubercles or tubercles with darker central papillac; stamens 10; anthers creamy yellow, ca. $1 \mathrm{~mm}$ long, dorsifixed; filaments very slender, pale, $0.8-1.7 \mathrm{~cm}$ long, varying in length within the same flower; perianth of 2 whorls; petals 5, deep rose to pink (rarely white), claw slender, 12-17 mm long, exserted 1-4 $\mathrm{mm}$ from the calyx, not strongly auriculate, the limb $8-15 \mathrm{~mm}$ long, ca. half as broad, usually bifid, with obtuse lobes; sepals 5, lobes broadly acute to rounded, 1.4-2.6 mm long, green or pinkish, hirsute, often glandular-pubescent with a weak to strong central vein, calyx tube elliptic-cylindric in flower to broadly ovoid in fruit, up to $1.5 \mathrm{~cm}$ long and broad, greenish with a yellowish or rosy tint, sparsely to densely hirsute, often glandular-pubescent; pedicels hirsute, often glandular-pubescent, 1-7 (10) mm long or flowers subsessile; inflorescence a sparse (female) to much-branched (male) dichasium of terminal and axillary flower clusters; inflorescence bracts broad, leaf-like, those directly subtending the flowers mostly $5-9 \mathrm{~mm}$ long, 3-6 mm broad, ovate to elliptic with acute to acuminate tips, often rosy-tinted, hirsute and glandular, particularly along the margins; cauline leaves narrowly elliptic to broadly obovate, mostly $2-13 \mathrm{~cm}$ long, $1-6 \mathrm{~cm}$ broad, with obtuse, acute or apiculate tips, entire margins and rounded to attenuate clasping bases, surfaces and margins puberulent to hirsute, sometimes with a few glandular hairs; basal rosette leaves similar to cauline leaves, but often spatulate with long petioles; petioles absent or obscure on upper cauline leaves to pronounced and 
winged below, up to $6 \mathrm{~cm}$ long on basal leaves, hirsute, often glandular-pubescent; stipules absent; stems green to tan or rosy-tinted above, usually grooved, pilose to densely hirsute-glandular, spreading or erect, up to 1 $\mathrm{m}$ tall; rhizomes developing from the caudex in the second season; root system a first and second year taproot, adventitiously rooting from the caudex and rhizome in established perennials $(2 n=24)$.

Infraspecific Variation: Plants of this species may rarely have white flowers. The hybrid, Silene dioica $\mathrm{x}$ latifolia has been reported. See also the discussion under $S$. latifolia.

Importance: These plants are uncommon and declining, mostly historically naturalized in New York State, but they sometimes become troublesome weeds in gardens and cultivated fields elsewhere.

Note: Silen nivea (Nutt.) Otth occurs at several sites in Pennsylvania along the New York border, and has been found once on a roadside in Sullivan Co., NY. Reports of New York State occurrences of Silene gallica L. [as S. anglica L. in House (1924) and elsewhere] were apparently based on specimens of S. dichotoma.

Waifs and Rare Garden Escapes: Silene conica L. (Suffolk, Co.); S. italica Pers. ssp. nemoralis (Waldst. \& Kit.) Nyman (Washington Co.), Silene nutans L. (reported from Richmond Co.), Silene virginica L. (probably gardengrown, Yates Co.)

\section{APPENDIX \\ SUPPLEMENT TO ASSOCIATED FUNGI}

Since the publication of Farr et al. (1989), a voluminous work on fungi and their plant hosts, we have modified this appendix in the New York State Flora volumes. The following list was compiled from the mycological collections of the New York State Museum (NYS) by J. Kenneth Dean, and represents only those records not listed by Farr et al.

Albugo portulacae (DC.) Kuntze, on Portulaca oleracea, Schultz 2179

Alternaria saponariae (Peck) Neergaard, on Saponaria officinalis, C.T. Rogerson 9-10-62, det. Rogerson Cladosporium herbarum (Pers.) Link ex Fr., on Agrostemma githago

Marssonina delastrei (DeLac.) Sacc., on Silene vulgaris (as S. cucubalis), C.T. Rogerson 9-10-62, det. Rogerson Melampsorella caryophyllaceorum Schroet. on Stellaria borealis

Puccinia arenariae (Schum.) Wint., on Arenaria stricta, W.R. Gerard, det. House, other collections on Spergula arvensis, Dianthus barbatus

Puccinia mariae-wilsoni Clinton, on Claytonia virginica, S.J. Smith 6539, det. Rogerson, other collections on C. caroliniana

Uromyces verruculosus Schr., on Silene latifolia (as Lychnis alba), R. Latham 1464, det. Jackson

Ustilago violacea (Pers.) Rouss., on Silene latifolia (as Lychnis alba); S.J. Smith 42172, det. C. Rogerson; other collections on Minuartia groenlandica; on Stellaria borealis, Stellaria longifolia and S. borealis x longifolia 


\section{BIBLIOGRAPHY}

Abdel Bari, E. 1973. Cytological studies in the genus Silene L. New Phytol. 72: 833-838.

Acheroy, M. 1987. Morphological and genetical variations between and within populations of Petrorhagia prolifera(Caryophyllaceac). Bull. Soc. Bot. Belg. 120: 72-80.

Aeschimann, D. 1981. Ėude biosystematique de Silene vulgaris s.l. (Caryophyllaceac) dans le domaine alpin. La sous-espéce glareosa dans les eboulis de Bourgogne. Saussurea 12: 33-47.

38: $575-617$. 1983a. Le Silene vulgaris s.l. (Caryophyllaceae), evolution vers une mauvaise herbe. Candollea

. 1983b. Ètude biosystematique de Silene vulgaris s.l. (Caryophyllaceae) dans le domaine alpin.

Traitement numerique des populations des Alpes occidentales et de la Bourgogne. Candollea 38: 155-202. . 1984a. Ėtude biosystematique de Silene vulgaris s.l. (Caryophyllaceae) dans le domaine alpin.

Morphologie de la graine. Candollea 39: 135-149.

. 1984b. Ėtude biosystematique de Silene vulgaris s.l. (Caryophyllaceae) dans le domaine alpin.

Typification du subsp. marginata (Kit.) Hayek. Candollea 39: 395-397.

. 1984c. Ètude biosystematique de Silene vulgaris s.l. (Caryophyllaceae) dans le domaine alpin.

Traitement numerique des populations des Alpes de quelques chaines voisines. Candollea 39: 399-415. . 1984d. Ėtude biosystematique de Silene vulgaris s.l. (Caryophyllaceae) dans le domaine alpin.

Bibliographic. Candollea 39: 417-422.

. 1985. Ètude biosystematique de Silene vulgaris s.l. (Caryophyllaceae) dans le domaine alpin. Essai

d'interpretation evolutif et propositions taxonomiques. Candollea 40: 67-98.

. 1983. Ėtude biosystematique de Silene vulgaris s.l. (Caryophyllaceae) dans le domaine alpin.

Notes nomenclaturales. Candollea. 38: 203-209.

, \& G. Bocquet. 1980. Les types biologiques du Silene vulgaris s.l. Candollea 35: 451-495.

, J. M. Mascherpa, \& G. Bocquet. 1981. Ėtude biosystematique de Silene vulgaris s.l. (Caryophyllaceae) dans le domaine alpin. Methodologie. Candollea 36: 379-396.

Akeroyd, J. R. 1988. Arenaria serpyllifolia L. and related species. pp. $335-338$ In: A. O. Chater, (ed.) Flora

Europaea: Notulae systematicae ad Floram Europaeam spectantes. Series 2. No. 2. Jour. Linn. Soc. Bot. 97: 335-355.

Al-Eisawi, D. 1989. Pollen morphology of Caryophyllaceae in Jordan. Mitt. Bot. Staats. München 28: 599-614.

Al-Nowaihi, A. S., \& E. G. El-Deen. 1977. Anatomical characters of some Caryophyllaceac as an aid in their identification. Proc. Egypt. Acad. Sci. 27: 99-105.

Al-Oqlah, A., \& F. M. Karim. 1990. Morphological and anatomical studies of seed coat in Silene species

(Caryophyllaceac) from Jordan. Arab. Gulf Jour. Sci. Res. 8: 121-139.

Alex, J. F. 1968. Competition between linseed flax and Saponaria vaccaria. Canad. Jour. Planı Sci. 48: 139-147.

Alexander, E. J. 1935. Silene virginica. Addisonia 19: 29-30 + pl. 623.

Allwood, M. C. 1947. Carnations and all Dianthus. Hayward's Heath, Sussex. xxxii +380 pp.

Andersson-Kotto, I., \& A. E. Gairdner. 1931. Interspecific crosses in the genus Dianthus. Genetica 13: 77-112 + tab. 1.

Ankei, T. 1988. Evolution of the stem structures of Stellaria (Caryophyllaceae). Jour. Phytogeog., \& Taxon. 36: $27-36$.

1989. Phenology and life cycles of Stellaria (Caryophyllaceae) with special reference to the evolution of their life forms. Jour. Phytogeogr. \& Taxon. 37: 43-52.

Anonymous. 1918. Night-flowcring catchfly (Silene noctiflora). Secd Branch Pamph. S-5, Ontario Domin. Dept. Agric., Ottawa.

Antonova, N. N., \& V. V. Petrovsky. 1986. Stellaria longipes (Caryophyllaceae) and its allies in the North-east of Asia. Bot. Zhur. 71: 57-66.

Arthur, J. C. 1898. A native white bedding plant: the starry grasswort (Cerastium ariense oblongifolium). Purdue Univ. Agr. Exp. Sta. Bull 74: 94-100 + pl. 1-6.

Assadi, M. 1985. The genus Dianthus L. (Caryophyllaceae) in Iran. Iranian Jour. Bot. 3: 9-54. 
Astie, M. 1956a. Sur quelques characteres teratologiques obtenus experimentalement chez la fleur de Saponaria officinalis. Compt. Rend. Acad. Paris 242: 407-410.

.1956b. Formation spontanée et experimentale de staminodes chez Saponaria officinalis L. Compt. Rend. 242: 1352-1354.

- 1957. Induction experimentale de pieces surnumeraires et de caracteres "d'inflorescences" chez Saponaria officinalis L. Compt. Rend. 244: 933-935.

, \& M. T. Le Bec. 1959. Quelques types d'inflorescence produits expermentalement chez le Saponaria officinalis L. et l'Euphorbia peplus L. Bull. Soc. Bot. Fr. 106: 1-7.

Baad, M. F. 1969. Biosystematic studies of the North American species of Arenaria, subgenus Eremogone (Caryophyllaceae). Ph.D. Dissertation, Univ. of Washington, Seattle.

. 1970. Biosystematic studies of the North American species of Arenaria, subgenus Eremogone (Caryophyllaceae). Am. Jour. Bot. 57: 752.

Badr, A., M. A. Hamoud, \& T. T. Elkington. 1987. Cytology and taxonomic relationships of some taxa in the genus Silene. Cytologia 52: 63-68.

Baeva, R. T., M. O. Karryev, V. I. Litvinenko, \& N. K. Abubakirov. 1974. Glycosides of Vaccaria segetalis. V. Vaccarin. Khim. Prirod. Soed. 10: 171-176.

Baig, N. A. 1973. Basic chromosome number in the genus Cerastium L. Pakistan Jour. Sci. 23: 267-268.

Bailey, L. H. 1938. A Garden of Pinks with Decorations. viii +142 pp. New York.

Baillon, H. 1886. Portulacacées. Hist. Pl. 9: 54-80.

. 1888. Caryophyllacées. Hist. P1. 9: 81-129.

Baker, H. G. 1947. Biological flora of the British Isles. Melandrium (Roehling em.) Fries. Jour. Ecol. 35: 271-292.

. 1950. The inheritance of certain characters in crosses between Melandrium dioicum and $M$. rubrum. Genetica 25: 126-156.

. 1958. Hybridization between dioecious and hermaphrodite species in the Caryophyllaceae. Evolution 12: 423-427.

, \& I. Baker. 1971. Amino-acids in nectar and thier evolutionary significance. Nature 241: 543-545.

Baksay, L. 1972. Biosystematik der Dianthus plumarius L. (sensu lato) in Ungarn. Symp. Biol. Hung. 12: 149-161.

Balabanova-Radonova, E. M., Ya. I. Georgieva, \& D. M. Mondeshka. 1982. Structure of certain Lychnis coronaria L. leaf components. Compt. Rend. Acad. Bulgare Sci. 35: 463-466.

Ball, P. W., \& V. H. Heywood. 1962. Taxonomic separation of the cytological races of Kohlrauschia prolifera (L.) Kunth sensu lato. Watsonia 5:113-116.

. 1964. A revision of the genus Petrorhagia. Bull. Brit. Mus. Bot. 3: 119-172. pl. 13-15.

Barberis, G. 1988. Cerastium utriense sp. nov. (Caryophyllaceae) nell'Appennino ligure-piemontese. Webbia 42: $153-160$.

Barkoudah, Y. I. 1962. A revision of Gypsophila, Bolanthus, Ankyropetalum, and Phryna. Wentia 9: 1-203.

Baskin, J. M., \& C. C. Baskin. 1973. Studies on the ecological life cycle of Holosteum umbellatum. Bull. Torrey Bot. Club 100: 110-116.

1975. Year-to-year variation in the germination of freshly-harvested seeds of Arenaria patula var. robusta from the same site. Jour. Tenn. Acad. 50: 106-108.

- 1982. Germination ecophysiology of Arenaria glabra, a winter annual of sandstone and granite outcrops of southeastern United States. Am. Jour. Bot. 69: 973-978. 26: $375-380$.

. 1986. Temperature requirements for after-ripening in seeds of nine winter annuals. Weed Res.

- 1987. Seed germination and flowering requirements of the rare plant Arenaria fontinalis (Caryophyllaceae). Castanea 52: 291-299.

Bate-Smith, E. C. 1962. The phenolic constituents of plants and their taxonomic significance. I. Dicotyledons. Jour. Linn. Soc. Bot. 58: 95-173.

Beguinot, A. 1910. Ricerche intorno al polimorfismo della "Stellaria media" (L.) Cyr. in rapporto alle sue condizioni di esistenza. II. Illustrazione sistematica della entita del ciclo de St. media e delle specie affine. Nuovo Gior. Bot. Ital. 17: 348-390. 
Behnke, H. D. 1976a. Die Siebelement-Plastiden der Caryophyllaceae, eine weitere spezifische Form der P-Type Plastiden bie Centrospermen. Bot. Jahrb. 95: 327-333.

.1976b. Ultrastructure of sieve-element plastids in Caryophyllales (Centrospermae), evidence for the delimitation and classification of the order. Pl. Syst. Evol. 126: 31-54.

, L. Pop, \& V. V. Sivarajan. 1983. Sieve-element plastids of Caryophyllales: additional investigations with species reference to the Caryophyllaceac and Molluginaceac. Pl. Syst. \& Evol. 142: 109-115. 1983.

Bernhardt, C. 1976. Effects of certain inhibitors on germination of Melandrium noctiflorum seeds stimulated by light, ether peroxidases, or a peper factor. Sov. Plant Physiol. 23: 139- 143.

Bittrich, V., \& M. do C. E. Amaral. 1991. Proanthocyanidins in the testa of centrospermous seeds. Biochem. Syst. Ecol. 19: 319-321.

Blackburn, K. B. 1928. Chromosome number in Silene and the neighbouring genera. Zeitschr. Indukt. Abstamm. Vererbunglehre Supp. I: 439-446.

, \& J. J. Boult. 1930. The status of the genus Saponaria and its near allies considered in the light of their cytology. Proc. Univ. Durham Philos. Soc. 8: 260-266.

, \& J. K. Morton. 1957. The incidence of polyploidy in the Caryophyllaceac of Britain and Portugal. New Phytol. 56: 344-351.

Blakeslee, A. F. 1920. A dwarf mutation of Portulaca showing vegetative reversions. Genetics 5: 419-433.

Böcher, T. W. 1951. Studies on the distribution of the units within the collective species of Stellaria longipes. Bot. Tiddskr. 48: 401-420.

1955. Experimental and cytological studies on plant species. II. Trifolium arvense and some other pauciennal herbs. Danske Vidensk. Selsk. Biol. Skr. 8(3): 1-31.

, \& K. Larsen. 1958. Experimental and cytological studies on plant species. IV. Further studies in short-lived herbs. Dansk. Vidensk. Selsk. Biol. Skr. 10(2): 1-24.

K. Larsen, \& K. Rahn. 1953. Experimental and cytological studies on plant species. I. KohIrauschia prolifera and Plantago coronopus. Hereditas 39: 289-304.

Bocque!, G. 1959. The campylotropous ovule. Phytomorphology 9: 222-227.

- 1961. The structure of the placental column in the genus Melandrium (Caryophyllaceae). Phytomorphology 9: 217-221.

- 1967. Physolychnidium olim Gastrolychnidium nomenclaturae fundamentum includens combinationes taxaue nova nonnulla Silenes generis. Candollea 22: 1-38.

. 1968. Cleistogamie et evolution chez les Silene L. sect. Physolychnis (Benth.) Bocquet. Candollea. 23: $67-80$.

1968b. De evolutione annotamenta aliqua silenis et imprimis earum sectione Physolychnide inducta. Arch. Sci. 21: 239-262.

1969. Revisio Physolychnidum (Silene sect. Physolychnis). Phanerogam. Monogr. 1: v +341 pp.

\& C. Bachni. 1961. Les Caryophyllacees-Silenoidees de la flore suisse. Candollea 17: 191-202.

, \& C. Favarger. 1971. Silva ad Silenologiam 3. Donnees cytologiques sur les Silene. L. sect.

Physolychnis (Bentham) Bocquet (Caryophyllaceae). Nat. Canad. 98: 251-260.

Bogle, A. L. 1969. The genera of Portulacaceae and Basellaceae in the southeastern United States. Jour. Arnold Arb. 50: 566- 598.

1970. The genera of Molluginaceae and Aizoaceae in the southeastern United States. Jour. Arnold Arb. 51: 431-462.

Boguslavskaya, L. I., S. I. Dem'yanenko, \& D. Khasan Salam. 1983a. Flavonoids of some species of the genus Dianthus. Khim. Prirod. Socd. 19: 386.

, \& V. A. Soboleva. 1983b. C-glycosides of Diamthus versicolor. Khim. Prirod. Soed. 19: 783-784.

A. 1. Tikhonov, P. D. Pashnev, B. Zhemal, \& V. I. Sklyar. 1985. C-Glycosides of Stellaria holostea. Khim. Prirod. Soed. 21: 410.

Boivin, B. 1953. Le groupe du Stellaria longifolia Muhlenberg (Caryophyllaceae). Sv. Bot. Tidskr. 47: 43-46. 1956. Stellaria sectio Umbellatae Schischkin. Sv. Bot. Tidskr. 50: 113-114.

Bouharmont, J. 1965. Note sur la cytologie de quelques espéces de Portulaca. Bull. Soc. Roy. Bot. Belgique 98: $175-188$. 
Bouillant, M. L., F. F. de Arce, J. Favre-Bonvin, J. Chopin, A. Zoll, \& G. Mathieu. 1979. Nouvelles C-glycosylflavones extraites de Spergularia rubra. Phytochemistry 18: 1043-1047.

Bowden, R. A. 1952. Carnations and photoperiodism in relation to temperature and ventilation in the deep south. Proc. Assoc. Southern Agric. Workers 49: 10\%.

Brandt, W. 1926. Verbreitung von Saponinen innerhalb der Centrospermae, Festschrift A. Tschirch, S. 13-22, Tauchnitz, Leipzig.

Braun, A. 1843. Beitrag zur Feststellung natürlicher Gattungen unter den Sileneen. Flora 26: 349-363, $365-388$. Breslavets, L. P., \& L. M. Kryzhanovskaya. 1965. Attempts of breeding new ornamental plants from wild ones. pp. 308-309. In: P. M. Zhukovsky \& A. S. Troshin (eds.) Poliploidiia i Selektsiia.

Brett, O. E. 1952. Basic chromosome numbers in the genus Cerastium. Nature 170: 251-252.

Britten, J. 1890. Buda v. Tissa. Jour. Bot. 28: 295-297.

Britton, N. L. 1889. Prelimiary note on the North Amercan species of the genus Tissa. Bull. Torrey Bot. Club 16: $125-129$.

Budzianowshi, J., \& G. Pakulski. 1991. Two C, O-glycosylflavones from Stellaria media. Pl. Medica 57: $290-291$. Buell, K. M. 1952a. Developmental morphology in Dianthus. I. Structure of the pistil and seed development. Am. Jour. Bot. 39: 194-210.

. 1952b. Developmental morphology in Dianthus. II. Starch accumulation in ovule and seed. Am. Jour. Bot. 39: 458-46\%.

. 1954. Developmental morphology in Dianthus. III. Seed failure following interspecific crosses. Am. Jour. Bot. 40: 116-123.

Burret, F., Z. Rabesa, P. Zandonella, \& B. Voirin. 1981. Contribution biochemique a la systematique de l'ordre des Centrospermales. Biochem. Syst. Ecol. 9: 257-260.

Buschmann, A. 1938. Über einiger ausdauernde Cerastium-Arten aus der Verwandtschaft des C. tomentosum Linne. Repert. Sp. Nov. 43: 118-143; (1939) 46: 33-35.

Buxbaum, F. 1961. Vorläufige Untersuchungen über Umfang, systematische Stellung und Gliederung der Caryophyllales (Centrospermae). Beitr. Biol. Pflanzen 36: 1-56.

Cai, Q., \& C. C. Chinnappa. 1989a. Studies on the Stellaria longipes polyploid complex (Caryophyllaceae): characterization of the genetic basis of isozymes. Canad. Jour. Bot. 67: 2960-2966.

. 1989b. Gene duplication of isozymes in the tetraploid of Stellaria longipes (Caryophyllaceae). Jour. Hered. 80: 112-117.

Campanella, J. J., K.-S. Chiang, \& M. Ruddat. 1987. Homologous DNA sequences in Silene alba (Caryophyllaceae), the host and its obligatory parasite, Ustilago violacea (Basidiomycetes). XIV Intl. Bot. Congr. Abst. 69.

Campbell, D. R. 1985. Pollinator sharing and seed set of Stellaria pubera -- competition for pollination. Ecology 66: 544-553.

Candau, P. 1978a. Palinologia del genero Cerastium L. (Caryophyllaceae). Palinologia 1: 115-119. - 1978b. Palinologia de Caryophyllaceae del Sur de España. I. Subfamilia Paronychioideae. Lagascalia 7: 143-157+ pl. 1-4.

1978c. Palinologia de Caryophyllaceae del Sur de Espana. II. Subfamilia Alsinoideae. Lagascalia. 8: $39-51+$ pl. $1-4$.

1979. Polen y semillas de las especies de Silene, Sect. Erectorefractae Chowdhuri. Lagascalia 8: 127-133. pl. 1-3.

1980. Palinologia en Caryophyllaceae del sur de Espana. - subfamilia Silenoideae. Lagascalia. 9: $137-147+$ pl. 1.2 .

, \& J. A. Devesa. 1984. Contribucion al conocimiento del polen y de las semillas del genero Spergularia en Andalucia occidental. Lazaroa 5: 187-200.

Candolle, A. P. de. 1829. Memoire sur la Famille des Paronychiees. Paris. 16 pp.

Cardona, M. A., \& J. Montserrat Marti. 1981. Ėtude cytotaxonomique de quelques Arenaria L. du nord-est de l'Espagne. Biol. Ecol. Medit. 8: 13-22.

Carlstrom, A. 1986. A revision of Arenaria sect. Orientales ser. Orientales incl. ser. Deflexae (Caryophyllaceae) in the Aegean and SW Turkey. Willdenowia 15: 359-374.

Carolin, R. C. 1954. Stomatal size, density and morphology in the genus Dianthus. Kew Bull. 1954: 251-258. 
1957. Cytological and hybridization studies in the genus Dianthus. New Phytol. 56: 81-97. 1987. A review of the family Portulacaceae. Australian Jour. Bot. 35: 383-412.

Catling, P. M., \& S. M. McKay. 1981. A review of the occurrence of halophytes in the eastern Great Lakes region. Mich. Bot. 20: 167-179.

Caudle, C., \& J. M. Baskin. 1968. The germination pattern of three winter annuals. Bull. Torrey Bot. Club 95: :31-335.

Celebioglu, T., \& C. Favarger. 1983. Contribution a la cytotaxonomie du genre Minuartia L. (Caryophyllacees) en Turquie et dans quelques regions voisines. Biol.-Ecol. Medit. 9: 139-160. 1984. Recherches cytotaxonomiques et cytogeographiques sur Minuartia sect. Sabulina en

Turquie (Caryophyllaceae). Pl. Syst. Evol. 144: 241-255. 1986. A propos du Minuartia montana L. et du Series Montanae Mattf. du genre Minuartia L. Candollea 41: 423-430.

1988. Correlation entre le nombre d'etamines par tleur et le nombre chromosomique chez Minuartia hybrida (Vill.) Schischkin (Caryophyllaceae). Nat. Monspel. Ser. Bot. 53: 3-15.

. 1990. Nouvelle contribution a la cytotaxonomie de la section Sabulina (Reichenb.) Graebner du genre Minuartia L. (Caryophyllaceae). Nat. Monspel. Ser. Bot. 55: 27-41.

, \& K. L. Huynh. 1983. Contribution a la micromorphologie de la testa des graines du genre Minuartia (Caryophyllaceae). I. Sect. Minuartia. Bull. Mus. Hist. Nat. Paris IV 5B (Adansonia): 415- 435. , \& J. M. Montserrat Marti. 1990. Sur la position systematique et les affinites du Minuartia valentina (Pau) Mateo \& Figuerola, endemique espagnole. Collec. Bot. 18: 75-85.

Chanda, S. 1962. On the pollen morphology of some Scandinavian Caryophyllaceae. Grana Palynol. 3(3): 67-98 + pl. $1-20$.

Chang, H. S., Y. B. Han, W. S. Woo, S. S. Kang, \& H. Lotter. 1989. Sapogenins from Melandrium firmum. Pl. Medica 55: 544-547.

Chang, C. P., \& T. J. Mabry. 1974. The constitution of the order Centrospermae: rRNA-DNA hybridization studies among betalain- and anthocyanin-producing families. Biochem. Syst. 1: 185-190.

Chaudhri, M. N. 1968. A revision of the Paronychiinae. Meded. Bot. Mus. Utrecht 285: 1-440.

Chaudhry, I. P., \& H. S. Narayana. 1978. Studies on the development and structure of seed in the Caryophyllaceac. I. Spergula arvensis L. Jour. Indian Bot. Soc. 57: 46-51.

Cheeseman, J. M., P.D. Bloebaum, \& L.K. Wickens. 1985. Short term $22^{\mathrm{Na}+}$ and $42^{\mathrm{K}+}$ uptake in intact, mid-vegetative Spergularia marina plants. Physiol. Plant. 65: 460-466.

Chevalier, C. 1948. Le genre Gypsophila. Rev. Hort. Paris 120: 295-297.

Chinnappa, C. C. 1985a. Studies on the Stellaria longipes complex (Caryophyllaceae): interspecific hybridization. I. Triploid meiosis. Canad. Jour. Genet. Cytol. 27: 318-321. 20: $46-58$. 1985b. Biosystematics of the Stellaria longipes complex (Caryophyllaceae). Jour. Cytol. Genet. 1992. Stellaria porsildii, sp. nov., a new member of the S. longipes complex. Syst. Bot. 17: 29-32. , \& J. K. Morton. 1974. The cytology of Stellaria longipes. Canad. Jour. Genet. Cytol. 16: 499-514. - 1976. Studies on the Stellaria longipes Goldie complex - variation in wild populations. Rhodora 78: $488-502$.

- 1984. Studies on the Stellaria longipes complex (Caryophyllaceae) - Biosystematics. Syst. Bot. 9: $60-73$. $129-135$.

1991. Studies on the Stellaria longipes complex (Caryophyllaceae) - Taxonomy. Rhodora 93:

Chirva, V. Ya., P. K. Kintya, \& G.V. Lazur'evskii. 1969. The question of the structure of a triterpene glycoside from Saponaria officinalis. Khim. Prirod. Soed. 5: 494-498.

Chowdhuri, P. K. 1957. Studies in the genus Silene. Notes Bot. Gard. Edinb. 22: 221-278.

Clarke, L. K. 1950. The Caryophyllaceae of Tennessee. Unpubl. M.S. Thesis, The Univ. of Tennessee, Knoxville. vi $+95 \mathrm{pp}$.

Clausen, R. T. 1939. Silene caroliniana. Rhodora 41: 575-584 + pl. 584.

Clements, F. E. 1889. Contributions to the histogenesis of the Caryophyllales, I. Trans. Am. Microscop. Soc. 20: $97-164$. 
Clute, O., \& O. Palmer. 1893. Spurry (Spergula arvensis). In: Two plants for a sandy land. Mich. Agr. Exp. Sta. Bull. 91: 3-8.

Clute, W. N. 1926. The meaning of plant names -- XXVI, XXVII. Caryophyllaceae. Am. Bot. 32: 52-55; 97-105.

Connard, M. H., \& P. W. Zimmerman. 1931. The origin of adventitious roots in cuttings of Portulaca oleracea. Contr. Boyce Thompson Inst. 3: 337-346.

Cook, M. T. 1903. The development of the embryo-sac and embryo of Agrostemma githago. Ohio Nat. 3: 365-369.

1909. Notes on the embryology of the Caryophyllaceae. Ohio Nat. 9: 477-481. 1909.

Ferry, S., \& N. Darbour. 1980. Sur les flavonoides et les anthocyanes de la nielle des bles Lychnis githago Scop. Plant Med. Phytother. 14: 148-154.

Cordell, G. A., R. L. Lyon, H. H. S. Fong, P. S. Benoit, \& N. R. Farnsworth. 1977. Biological and phytochemical investigations of Dianthus barbatus cv. "China Doll" (Caryophyllaceae). Lloydia 40: 361-363.

Core, E. L. 1939. A taxonomic revision of the genus Siphonychia. Jour. Elisha Mitchell Soc. 55: 339-345. 1940. Notes on the mid-Appalachian species of Paronychia. Virginia Jour. Sci. 1: 110-116. 1941. The North American species of Paronychia. Am. Midl. Nat. 26: 369-397.

Correns, C. 1909. Untersuchungen über die Gattung Cerastium. I. Die Verwertung der Haarformen fur die Unterscheidumg der Arten. Österr. Bot. Zeitschr. 59: 169-183.

Corillion, R. 1958. Sur la présence du Mollugo verticillata L. (Aizoacée) à L'état spontané dans le Val de Loire. Mếm. Soc. Bot France 105: 51-52.

Cory, V. L. 1944. Paronychia in central and western Texas. Rhodora 46: 278-281.

Costa, A. S., \& A. M. B. Carvalho. 1960. Common purslane (Portulaca oleracea) as a reservoir of the tomato spotted wilt virus. Gragantia 19: 21-25.

Crang, R. E., \& H. L. Dean. 1971. An intergeneric hybrid in the Sileneae (Caryophyllaceae). Bull. Torrey Bot. Club 98: 215-217.

Creasy, W. D. 1963. Development of the megaspore, megagametophyte, and embryo of Arenaria Fendleri var. Fendleri. Castanea 26: 140-146.

Crete, P. 1947. Embryogenie des Caryophyllacees. Developpement de l'embryon chez le Stellaria uliginosa Murr. Compt. Rend. Acad. Paris 225: 588-590.

1948. Embryogenie des Caryophyllacees. Developpement de l'embryon chez le Saponaria officinalis L. Compt. Rend. Acad. Paris 226: 111-113.

Crow, G. E. 1974. A revision of the North American species of Sagina (Caryophyllaceae). Unpubl. Ph.D. Dissertation, Michigan State Univ., East Lansing. 228 pp.

1978. A taxonomic revision of Sagina (Caryophyllaceae) in North America. Rhodora 80: 1-91. 1979. The systematic significance of seed morphology in Sagina (Caryophyllaceae) under scanning electron microsopy. Brittonia 31: 52- 63.

Currie, R. R. 1988. Endangered and threatened wildlife and plants; determination of status for Arenaria cumberlandensis. Federal Register 53: 23745- 23748.

Cusick, A. W. 1983. Spergularia (Caryophyllaceae) in Ohio. Mich. Bot. 22: 69-71.

1988. Noteworthy Collections. Pennsylvania. Spergularia marina (L.) Griseb. and S. media L. Castanea 53: 312.

Dahlgren, V. O. 1940. Über den Gynäzeumbau der Gattung Scleranthus. Bot. Not. 1940: 231-236.

Danin, A., \& L. C. Anderson. 1986. Distribution of Portulaca oleracea (Portulacaceae) subspecies in Florida. Sida 11: 318-324.

Darmograi, V. N. 1976. The flavonoids of some plants of the family Caryophyllaceae. Khim. Prirod. Soed. 12: 540-541.

1977. Flavonoids of plants of the genera Silene and Otites Adans, family Caryophyllaceae. Khim. Prirod. Soed. 13: 114-115.

1979. Flavonoids of some species of the genera Arenaria and Cerastium. Khim. Prirod. Soed. 15: 93.

Darwent, A. L. 1975. The biology of Canadian weeds. 14. Gypsophila paniculata. L. Canad. Jour. Pl. Sci. 55: 1049-1058. 
, \& R.T. Coupland. 1966. Life history of Gypsophila paniculata. Weeds 14: 313-318.

Davis, R. J. 1966. The North American perennial species of Claytonia. Brittonia 18: 285-303.

, \& R. G. Bowmer. 1966. Chromosome numbers in Claytonia. Brittonia 18: 37-38.

Dean, H. L. 1963. Further variation in style number and other gynoecial structures of Lychnis alba Mill. Phytomorphology 13: 1-13.

Deane, W. 1910. Some facts relating to Silene antirrhina. Rhodora 12: 129-131.

Degraeve, N. 1980. Ėtude de diverses particularites caryotypiques des genres Silene, Lychnis et Melandrium. Bol. Soc. Brot. II 53: 595-643.

Delisle, A. L. 1934. Anychia canadensis in Hampshire County Massachusetts. Rhodora 36: 58-59.

Devi, H. M., \& S. V. Krishna. 1990. Embryology of Sagina procumbens L. and Drymaria cordata Willd.

(Caryophyllaceac). Jour. Jap. Bot. 65: 211-219.

Devine, V. 1950. Embryogeny of Lychnis alba. Am. Jour. Bot. 37: 197-208.

Doyle, J. J. 1983. Flavonoid races of Claytonia virginica, Portulacaceac. Am. Jour. Bot. 70: 1085-1091.

. 1984a. Leaf morphology of Claytonia - racial and clinal variation. Canad. Jour. Bot. 62: 1469-

1473.

62:

. 1984b. Karyotypic variation of eastern North American Ciaytonia chemical races. Am. Jour. Bot.

. 1988. Natural interspecific hybridization in eastern North American Claytonia. Am. Jour. Bot. 75: $1238-1246$.

, R. N. Beachy \& W. H. Lewis. 1984. Biosystematic studies of eastern North American Claytonia ribosomal gene variation. (Abstr.) Am. Jour. Bot. 71: 132.

Dubois, M. A., A. Zoll, \& J. Chopin. 1985. Isomollupentin-O-glucosides from Cerastium arvense. Phytochemistry 24: $1077-1080$.

Duncan, W. H. 1950. A new varicty of Arenaria. Phytologia 3: 282.

Dvorák, F. 1980. Karyotype and variability of Holosteum umbellatum L. in Bohemia and Moravia. Scr. Fac. Sci. Nat. Univ. Purkynianae Brun. 10: 259- 266.

- 1984. Annotated chromosome counts for Arenaria leptoclados, Arenaria patula and Arenaria serpyllifolia. Biologia (Bratislava) 39: 833-840.

, \& F. Kuhn. 1980. Spergula arvensis L. and Spergula maxima Weihe: chromosome counts and the distribution in Czechoslovakia. Scr. Fac. Sci. Nat. Univ. Purkynianac Brun. 10: 429-446.

Eckhardt, T. 1964. Caryophyllaceae. In: H. Melchior. - A. Engler's Syllabus der Pflanzenfamilien. ed. 12, 2 : 93-96.

1976. Classical morphological features of Centrospermous families. Pl. Syst. Evol. 126: 5-25.

Ehrendorfer, F. 1976. Chromosome numbers and differentiation of Centrospermous families. Pl. Syst. Evol. 126: $27-30$.

Ehrhart, J. F. 1783. Botanische Zurechtweisungen und Beschreibung zweyer neuen Pflanzen, Moehringia und Honckenya. Neues Mag. Aerzte 5: 193-208. 1788. Honkenya, eine Pflanzengattung. In: Ehrhart, J. F., Beiträge zur Natürkunde 2: 180-183. Hannover \& Osnabrück.

Emino, E. R., \& H. P. Rasmussen. 1971. Scanning electron microscope studies of the shoot apex in Dianthus canjophyllus L. cv. Scania. Jour. Am. Soc. Hort. Sci. 96: 253-256.

Enemoto, N. 1923. Studies on an ever-segregating race in Portulaca grandiflora. Jap. Jour. Bot. 1: 137-151.

Engel, T., \& W. Barthlott. 1988. Micromorphology of epicuticular waxes in Centrosperms. Pl. Syst. Evol. 161: 71-85.

Erhardt, A. 1991. Pollination of Dianthus superbus L. Flora 185: 99-106.

Ertter, B. 1985. Paronychia ahartii (Caryophyllaceac), a new species from California. Madroño 32: 87-90.

Eynden, G.P.A. Van Den. 1955. Some problems in the breeding of spurry (Spergula arvensis). Euphytica 4: 1-6.

Farestveit, B. 1968. Vacksthusnelliken, Dianthus caryophy'llus L. -- track af dens udviklingshistoric. (In Danish.) Horticultura 22(4): 59-62.

Farooqui, P. 1981. Note on the ultrastructure of Dianthus stomata. Indian Jour. Forestry 4: 150. 
Farr, D. F., G. G. Bills, G. P. Chamuris \& A. Y. Rossman. 1989. Fungi on Plants and Plant Products in the United States. The American Phytopathological Society Press. 1252 pp.

Favarger, C. 1946. Recherches caryologiques sur la sous-famille des Silenoides. Ber. Schweiz Bot. Ges. 56: $364-466$.

1956. Sur le nombre des cellules meres dans l'ovule des Cerastium et sur la pluralité des megasporocytes en general. Bull. Soc. Neuchatel Sci. Nat. 79: 89-118.

1962a. Contribution a l'etude cytologique des genres Minuartia et Arenaria. Bull. Soc. Neuchatel.

Sci. Nat. $85:$ 53-81.

. 1962b. L'evolution parallele du caryotype. Revue Cytol. Biol. Vegetales 25: 277-286.

1965. A striking polyploid complex in the alpine flora: Arenaria ciliata. L. Bot. Not. 118: 273-280.

1966. Contribution a la cytotaxinomie du genre Petrorhagia (= Tunica). Ber. Schweiz. Bot. Ges.

76: $270-278$.

1967. Nombres chromosomiques de quelques taxa principalement balkaniques de genre Minuartia

(L.) Hiern. Bot. Jahrb. 86: 280- 292.

1972. Contribution a l'etude cytotaxonomique de la flore des Apeninnins. II. Le groupe du Cerastium tomentosum L. Saussurea 3: 65-71.

. 1976. Nouveau nombre chromosomique < de base > pour le genre Cerastium L. et phenomenes endomitotiques chez Cerastium dominici Favarger. Bull. Soc. Neuchatel. Sci. Nat. 99: 87-92.

\& G. Nieto Feliner. 1988. On the races of Arenaria tetraquetra L. Jour. Linn. Soc. Bot. 97: 1-8.

\& P. Montserrat Recoder. 1987. Commentaires sur la caryologie des espéces de Minuartia L. de

la Peninsule Iberique. Anal. Inst. Bot. Cavanilles 44: 558-564.

Fenzl, E. 1833. Versuch einer Darstellung der geographischen Verbreitungs- und Vertheilungs-verhältnisse der natürlichen Familie der Alsineen in der Polarregion und eines Theiles der gemässigten Zone der alten Welt. Wien. $72 \mathrm{pp}$.

1839-1840. Caryophyllaceae. pp. 955-974. In: S. L. Endlicher, Gen. Pl., Vien.

1841. Monographie der Mollugineen und Steudilieen. 1. Suppl. Abh. Ann. Wiener Mus.

Naturges. 1-2: 279-307.

1842. Gypsophila and Alsineae. In: C. F. Ledebour, Flora Rossica. 1: 288-300; 337-420. Stuttgart.

1843. Sclerantheae and Paronychieae. In: C. F. Ledebour, Flora Rossica. 2: 156-158, 158-171.

Stuttgart.

Fernald, M. L. 1914. The American variations of Stellaria borealis. Rhodora 16: 144-151.

1915. Two variations of Silene antirrhina. Rhodora 17: 96-97.

1919a. The unity of the genus Arenaria. Rhodora 21: 1-7.

1919b. The earlier names for Alsinopsis. Rhodora 21: 9-12.

1919c. The specific identity of Arenaria groenlandica and A. glabra. Rhodora 21: 17-21.

1925. Notes on Sagina. Rhodora 27: 130-131.

1944. Spergula pentandra in America. Rhodora 46: 88.

1950. Our American forms of Stellaria alsine. Rhodora 52: 250-251.

\& A. C. Kinsey. 1943. Edible Wild Plants of Eastern North America. (revised ed., 1958). Harper

\& Row Publ. 452 pp.

157-163.

\& K. M. Wiegand. 1910. Notes on some northeastern species of Spergularia. Rhodora 12: $169-179$.

Ferry, S., \& N. Darbour. 1979. Sur les Acides-phenols de trois espéces de Lychnis: Lychnis alba Mill., Lychnis flos-cuculi L., Lychnis githago Scop. Plant. Med. Phytother. 13: 192-198.

Firbank, L. G. 1988. Biological flora of the British Isles No. 165. Agrostemma githago L. (Lychnis githago (L.) Scop.). Jour. Ecol. 76: 1232-1246.

Fischer, R. 1930. Über den Saponinnachweis in der Pflanzen mit Blütgelatine. Akad. Wien. Sitz.-ber. 139: 321-354.

Fish and Wildlife Service. 1990. Endangered and threatened wildlife and plants; review of plant taxa for listing as endangered or threatened species; notice of review. Fedcral Register 55: 6183-6229. 
Flores, S. E., \& J. D. Medina. 1971. Fatty acids obtained from Arenaria venezuelana f. Jahmii (Blake) Stey. Acte Cien:. Venezolana 22: 147-148.

Fournier, P. 1948. Le livre des plantes medicinales et veneeuses de France. 2: 504 pp., 3: 636 pp. Paris.

Fowler, H. S. 1950. The two-faced plant. Cornell P1. 7: 26-28. Franz, E. 1908. Beiträge zum Kenntnis der Portulacaceen und Basellaceen. Bor. Jahrb. 42: $1-48$.

Fredericks, N., K. L. Chambers, \& J. M. Miller. 1991. Character analysis, floral Mlavonoids, and phylogeny of annual and rhizomatous Claytonia, Portulacaceae. (Abst.) Am. Jour. Bot. 78 (6 suppi.): 232.

Friedrich, H.C. 1961-1971. Illecebraceae and Caryophyllaceae (excl. Silenoideae). In: K H. Rechinger (ed.). Illus. Fl. Mittel-europa. (ed.) 2. 3(2): 749-762, 763-945.

Gadella, T. W. J. 1977. Cvtotaxonomic studies in Stellaria graminea L. in the Netherlands. Hroc. Roy. Neth. Acad. Sci. C. 80: 161-170.

Gallagher, J. E., \& C. C. Jack. 1958. Chickweed control test 1956-57. Northeast. Weed Control Conf. Proc. 12: $151-153$.

Gams, H. 1953. Beiträge zur Kenntnis der arktisch-alpinen Saginen. Phyton Austria 5: 107-177.

Gartner, H. 1939. Zur systematischen anordnung einiger Arten der gattung Cerastium L. Repert. Sp. Nov. Beilt. 113: 1-95.

Gay. J. 1845. Holostei, Caryophyilearum Alsinearum Generis, Monographia. Ann. Sci. Nat. Bot. III. 4: 23-44.

Gentscheff, G. 1937. Experimental and caryological investigation of the relationship among the species of the genus Dianthus L. Diss. Univ. Sofia. 55 pp.

Gervais, C., \& M. M. Grandtner. 1981. The cytology and ecology of four Quebec, Canada, populations of Claytonia caroliniana var. caroliniana. Canad. Jour. Bot. 59: 1685-1701.

Ghazanafar, S. A. 1983a. Seed characters as diagnostic in the perennial sections of the genus Silene L. (Family Caryophyllaceae) -- I. Pakistan Jour. Bot. 15: 7-12.

1983b. New taxa, combinations \& notes on typification \& nomenclature in silene sect. Siphonomorpha \& Auriculatae. Notes Bot. Gard. Edinb. 41: 97-107.

. 1984. Pollen morpholgy of the genus Silene L. (Caryophyllaceae), sections Siphonomorpha Otth. and Auriculatae (Boiss.) Schischk. New Phytol. 98: 683-690.

- 1989. Hybridization studies in the genus Silene sects. Siphonomorpha and Auriculatae (Caryophyllaceae). P1. Syst. Evol. 168: 143-148.

Giannasi, D. E., G. Zurawski, G. Learn, \& M. T. Clegg. 1992. Evolutionary relationships of the Caryophyllidae based on comparative rbcL sequences. Syst. Bot. 17: 1-15.

Gibbs, L. S. 1907. Notes on the development and structure of the seed in the Alsinoideae. Ann. Bot. 21: 25-55 + pl. $5-6$.

Gifford, D. J., \& C. C. Chinnappa. 1986. Studies on the Stellaria longipes complex (Caryophyliaceae). VII. The seed proteins. Canad. Jour. Bot. 64: 1327-1330.

Girault, J. P., M. Bathori, E. Varga, K. Szendrei, \& R. LaFont. 1990. Isolation and identification of new ecdysteroids from the Caryophyllaceae. Jour. Nat. Products 53: 279-293.

Glushchenko, G. 1. 1974. Cytoembryological study of Silene latifolia (Mill.) Rendle et Britt. in connection with the problems of sterility. Ukranian Bot. Zhur. 31: 155-159.

Godeau, M. M. 1973a. Étude au microscope electronique a balayage des teguments seminaux des Arenaria armoricains du groupe serpyllifolia L. Compt. Rend. Acad. Paris D 276: 537-540.

1973b. Stellaria media (L.) Vill., S. neglecta Weihe, S. pallida (Dum.) Pire: observation des teguments seminaux au microscope electronique a balayage. Compt. Rend. Acad. Paris D 277: 2381-2384.

Godron, M. 1847. Obsrvations critiques sur l'inflorescence consideree comme base d'un arrangement methodique des espéces du genre Silene. Mem. Soc. Roy. Sci. Lett. Arts Nancy 1846: 135-175.

Gohil, R. N., \& P. S. Bali. 1973. A new base number for the genus Gypsophila. Curr. Sci. Bangalore 42: 256.

Goldberg, A. 1988. Classification, evolution, and phylogeny of the families of Dicotyledons. Smithson. Contrib. Bot. 58: iii + 314 pp.

Good, D. A. 1984. A revision of the Mexican and Central American species of Cerastium (Caryophyllaceae). Rhodora 86: 339-379.

Gorshkova, S. G. 1936. Viscaria Rochl., Lychnis L., and Coronaria L. In: B. K. Schischkin (ed.) Fl. USSR 6: 576-577, 692-699, 699-700. 
Gorske, S. F., A. M. Rhodes, \& H. J. Hopen. 1980. A numerical taxonomic study of Portulaca oleracea. Weed Sci. 27: 78-79.

Goyder, D. J. 1988. A revision of Arenaria section Plinthine. Jour. Linn. Soc. Bot. 97: 9-32.

Gräbner, K., \& P. Gräbner. 1921. Silenoideae. 1920-1923. In: P. Ascherson \& P. Gräbner. Synopsis der Mitteleuropäischen Flora 5: 1-503.

Gräbner, P. Alsinoideae. 1915-1919. In: P. Ascherson \& P. Gräbner. Synopsis der Mitteleuropäischen Flora 5(1): 446-934. Leipzig.

Grandtner, M. M., \& C. Gervais. 1985. Extreme precocity and thermal conditions of the apical and flora! development in Claytonia caroliniana var. caroliniana. Canad. Jour. Bot. 63: 1516-1520.

.1990. Initial stages of the in situ development of Claytonia caroliniana var. caroliniana. Canad. Jour. Bot. 68: 726-730.

Graves, J. S. 1894. Does Claytonia develop during the winter months? Asa Gray Bull. 5: 17.

Gray, A. 1887. A revision of some polypetalous genera and orders. Proc. Am. Acad. Arts Sci. 22: 270-314.

Greene, E. L. 1905. A proposed new genus, Anotites. Leafl. Bot. Observ. Crit. 1: 97-105.

Grenier, C. 1841. Monographia de Cerastio. Mem. Compt. Rend. Soc. Emul. Doubs 1: 95 pp.

Greuter, W., \& P. Mouterde. 1970. Petrorhagia syriaca (Caryophyllaceae): une rehabilitation. Candollea 25: 221-227.

Guignard, J. L. 1963. Embryogenie des Caryophyllacees. Developpement de l'embryon chez le Dianthus armeria L. Compt. Rend. Acad. Paris 256: 756-758.

. 1965. Embryogenie des Caryophyllacees. Developpement de l'embryon chez le Lychnis viscaria L. Compt. Rend. Acad. Paris 260: 3144-3147.

- 1966a. Embryogenie des Caryophyllacees. Developpement de l'embryon chez le Cerastium glomeratum Thuill. Compt. Rend. Acad. Paris D 263: 856-859.

- 1966b. Embryogenie des Caryophyllacees. Developpement de l'embryon chez le Gypsophila elegans Bieb. Compt. Rend. Acad. Paris 262: 2718-2721.

, \& J. C. Mestre. 1967a. Embryogenie des Caryophyllacees. Developpement de l'embryon chez le Silene armeria L. Compt. Rend. Acad. Paris D 264: 907-910.

1967b. Embryogenie des Caryophyllacees. Developpement de l'embryon chez le Cerastium pumilum Curt. Compt. Rend. 265: 111-114.

Gvinianidze, Z. I. 1965a. Specierum tribus Lychnideae familiae Caryophyllaceae epidermidis folii investigatio. Not. Syst. Geog. Inst. Bot. Thbilissi. 24: 41-48.

1965b. Specierum tribus Diantheae familiae Caryophyllaceae epidermidis folii investigatio. Not.

Syst. Geog. Inst. Bot. Thbilissi 25: 65-68.

1967. On the position of tribes Lychnideae Fenzl emend. A. Br. and Diantheae Pax in the

Carnation family. Akad. Nauk. Gruz. SSR. Tiflis Bot. Inst. Trudy 25: 96-113.

1984. Ad palynomorphologiam familiae Caryophyllaceae.Not. Syst. Geog. Inst. Bot. Thbilissi. 40: $30-38$.

Halket, A. C. 1931. The flowers of Silene saxifraga L. an inquiry into the casue of their day closure and the mechanism concerned in effecting their periodic movements. Ann. Bot. 45: 15-37.

310-314.

Halliday, G. 1964. Minuartia L. In: T. G. Tutin el al. (eds.) Fl. Europaea 1: 125-132.

Hammer, K., P. Hanelt, \& H. Knupffer. 1982. Vorarbeiten zur monographischen darstellung von Wild pflanzensortimenten: Agrostemma L. Kulturpflanze 30: 45-96.

Handel, S. N. 1978. New ant-dispersed species in the genera Carex, Luzula and Claytonia. Canad. Jour. Bot. 56: $2925-2927$.

Hara, H. 1952. Contributions to the study of variations in the Japanese plants closely related to those in Europe or North America. Part 1. Jour. Fac. Sci. Univ. Tokyo Bot. 6: 29-96.

Harborne, J. B. 1975. The biochemical systematics of flavonoids. In: J. B. Harborne, T. J. Mabry, \& H. Mabry. The flavonoids. vol. 2: 1056-1095. New York \& San Francisco.

Hardin, J. W., \& J. M. Arena. 1974. Human Poisoning from Native and Cultivated Plants. 2nd ed., Duke Univ. Press, Durham. 194 pp. 
Harley, J. L., \& E. L. Harley. 1987. A checklist of Mycorrhizae in the British Flora. New Phytol. 105 (Suppl.): $1-102$.

Harper, R. M. 1904. The type locality of Arenaria brevifolia. Torreya 4: 138-141.

Harriman, N. A., \& J. F. McCormick. 1963. A new base number in the genus Arenaria (Caryophyllaceae). Bull. Torrey Bot. Club 90: 148-149.

Hartman, R. L. 1974. Rocky Mountain species of Paronychia (Caryophyllaceae): a morpholgical, cytological, and chemical study. Brittonia 26: 256-263.

Harvey, J. H. Gillyflower and carnation. 1978. Gard. Hist. 6: 46-57.

Heaslip, M. B. 1951. Some cytoecological aspects in the evolution of certain species of the plant genus Silene. Ohio Jour. Sci. 51: 62-70.

Hegi, G. 1911. Systematische Gliederung des Dianthus carthusianorum L. Allgem. Bot. Zeitschr. 17: 11-18.

Hegnauer, R. 1964. Chemotaxonomie der Pflanzen. vol. 3. Basel und Stuttgart. 743 pp.

Heide, O. M., K. Pedersen, \& E. Dahl. 1990. Environmental control of flowering and morphology in the high-arctic Cerastium regelii, and the taxonomic status of $C$. jenisejense. Nordic Jour. Bot. 10: 141-147.

Hershkovitz, M. A. 1990. Nomenclatural changes in Portulacaceae. Phytologia 68: 267-270.

- 1991. More Centrospermae III: The Caryophyllaceous alliance, Aizoaceae, odd taxa, and summary. (Abstr.) Am. Jour. Bot. 78: 192.

. 1993. Revised circumscriptions and subgeneric taxonomies of Calandrinia and Montiopsis (Portulacaceae) with notes on the phylogeny of the portulacaceous alliance. Ann. Missouri Bot. Gard 80: 333-365.

Hickman, J. C. 1972. Arenaria section Eremogone (Caryophyllaceae) in the Pacific Northwest: a key and discussion. Madroño 21: 201-207.

Hiern, W. P. 1899. Alsine in the British flora. Jour. Bot. 37: 317-322.

Hitchcock, C. L., \& B. Maguire. 1947. A revision of the North American species of Silene. Univ. Wash. Publ. Biol. 13: 1-73.

Hollick, A., \& N. L. Britton. Cerastium arvense L. and its North American varieties. Bull. Torrey Bot. Club 14: $45-51+$ pl. 63-65.

Holm, T. 1905. Claytonia Gronov., a morphological and anatomical study. Mem. Natl. Acad. Sci. 10: 25-37. .1908. Method of hibernation and vegetative reproduction in North American species of Stellaria. Am. Jour. Sci. 25: 315-322. 1911. Mollugo verticillata L. Am. Jour. Sci. IV. 31: 525-532.

Hooker, J. D. 1880, 1883. 1llecebraceac. In: G. Bentham \& J. D. Hooker. Gen. P1. 3: 12-19; 6: 1218.

Hooker, W. J. 1829. Portulaca grandiflora. Hook. Bot. Mag. 56: pl. 2885.

Hooper, S. S. 1959. The genus Dianthus in central and south Africa. Hook. Icon. V. 7(1): 1-60 + pl. 3601-3624. House, H. D. 1921. Nomenclatorial notes on certain American plants 1. Am. Midl. Nat. 7: 126-135. 1924. Annotated List of the Ferns and Flowering Plants of New York State. New York State Mus. Bull. 254. 759 pp.

Howell, T. 1893. A rearrangement of American Portulacaceac. Erythea 1: 29-41.

Hull, E. D. 1949. Dianthus armeria as a biennial. Am. Bot. 48: 120-121.

Hultén, E. 1943. Stellaria longipes Goldie and its allies. Bot. Not. 1943: 251-270.

1956. The Cerastium alpinum complex. A case of world-wide introgressive hybridization. Svensk. Bot. Tidskr. 50: 411-495.

1964. Remarkable range extension for Minuartia groenlandica (Retz.) Ostenf. Svensk. Bot. Tidskr. 58: $432-435$.

Ikeno, S. 1921. Studies on the genetics of flower-colors in Portulaca grandiflora. Jour. Coll. Agric. Univ. Tokyo 8: 93-133.

lkonnikov, S. 1975. Notae de Caryophyllaceis, 3. 1. On the genus Behenantha (Otth) Schur in USSR. Novit. Syst. Pl. Vasc. 12: 196-200.

Ishii, T. 1930. Chromosome studies in Dianthus. I. Cytologia 1: 335-339.

lwanami, Y. 1962. The movements of the stamens of Portulaca grandiflora. 1. Bot. Mag. Tokyo 75: 133-139; 289-295; 331-335. 
, \& I. Hoshino. 1963. The opening and closing movement of the flower of Portulaca grandiflora II. Bot. Mag. Tokyo 76: 108-114.

Iwashina, T., \& S. Ootani. 1987. Characterization of C-glycosylflavones and anthocyanins in several species of Caryophyllaceae. Ann. Tsukaba Bot. Gard. 6: 19-30.

Jalas, J. 1963. Notes on Cerastium L., subsect. Perennia Fenzl. Arch. Soc. Zool. Bot. Fenn. Vanamo 18: 57-65. \& P. D. Sell. 1967. Cerastium fontanum Baumg. In: P. D. Sell. Taxonomic and nomenclatural notes on the British flora. Watsonia 6: 292-294.

, \& F. H. Whitehead. 1964. Cerastium L. In: T. G. Tutin et al., (eds.) Fl. Europaea 1: 136-145. Janchen, E. 1955. Naturgemässe Anordnung der mitteleuropäischen Gattungen der Silenoideae. Osterr. Bot. Zeitschr. 102: 381-386.

1956 (-1960). Catalogus Florae Austriae. I. Pteridophyten und Anthophyten (Farne und Blütenpflanzen). Vienna. 999 pp.

Jeanmonod, D. 1984. Revision de la section Siphonomorpha Otth dy genre Silene L. (Caryophyllaceae) en Mediterranee occidentale. II: Le groupe du S. mollissima. Candollea 39: 195-260.

, \& J. M. Mascherpa. 1982. Revision de la section Siphonomorpha Otth dy genre Silene L. (Caryophyllaceae) en Mediterranee occidentale. Methodologie. Candollea 37: 497-523.

Joesting, F. 1902. Beiträge zur Anatomie der Sperguleen, Polycarpeen, Paronychieen, Sclerantheen und Pterantheen. Beih. Bot. Centr. 12: 139-181.

Johnson, M. C. 1961. Observations of Dianthus armeria. Castanea 26: 100-101.

Jones, V., \& P. W. Richards. 1962. Biological flora of the British Isles. Silene acaulis (L.) Jacq. Jour. Ecol. 50: 475-487.

Joshi, P.C. 1935. Development of anomalous secondary vascular rings in the root of Spergula L. Proc. Indian Acad. B. 1: 729-735.

1936. Some phases of the life-history of two Tibetan Caryophyllaceae - Arenaria musciformis Wall. and Thylacospermum rupifragum Schrenk. Proc. Indian Acad. B 4: 471-482.

Judd, W. S. \& R. P. Wunderlin. 1981. First report of Portulaca amilis in the United States. Sida 9: 135-138.

Julin, E. 1960. Spontaneous occurrences of the hybrid Dianthus barbatus $\mathrm{x}$ superbus in Sweden. Sv. Bot. Tidskr. 53: $492-498$.

Kamelina, O. P., \& G. V. Yakovleva. 1982. Megasporogensis and development of the embryo sac in Dianthus caryophyllus (Caryophyllaceae). Bot. Zhur. 67: 80-87.

Kameoka H., C.-P. Wang, \& T. Yamaguchi. 1978. The constituents of the essential oil from Stellaria aquatica Scop. Nippon Nogeikagaku Kaishi 52: 335-340. 1978. In: Jour. Agric. Biol. Chem. 42: A22.

Kamps-Heinsbroek, J. W. Maas, J. M. Steyns, \& J. van Brederode. 1983. The flavones of the european species of Silene section Elisanthe. Zeitsch. Naturf. 38c: 894-898.

. H. C. Prentice, J. Heringa, \& P. Hogeweg. 1984. Corresponding patterns of geographic variation among populations of Silene latifolia $(=S$. alba $=$ S. pratensis) (Caryophyllaceae). Pl. Syst. Evol. 145: 227-242.

, R. Kamps-Heinsbroek, J. van Brederode, G. J. Niemann, \& G. van Nigtevecht. 1983. Geographic trends in flavone- glycosylation genes and seed morphology in European Silene pratensis (Caryophyllaceae). Pl. Syst. Evol. 141: 257-271.

Karim, F. M., \& A. Al-Oqlah. 1989. Palynological studies in the genus Silene (Caryophyllaceae) from Jordan. Arab. Gulf Jour. Sci. Res. 7: 109-124.

Kato, T. 1987. Hybridization between Dianthus superbus var. longicalycinus and D. shinanensis, evidenced by resolvable esterase isozymes from herbarium specimens. Ann. Tsukuba Bot. Gard. 6: 9-18.

Ke, P. 1985. Materials on the genus Stellaria in China. Acta Bot. Yunnan. 7: 69-82.

Khoshoo, T. N. 1960. Basic chromsome numbers in Silene and Saponaria. Nature 186: 412-413.

- 1965. Biosystematics of Indian plants - I. Saponaria vaccaria Linn. Bull. Natl. Bot. Gardens Lucknow 116: 1-54.

, \& S. K. Bhatia. 1961. Cytogenetics of the intergeneric hybrid, Vaccaria grandiflora x Saponaria vaccaria. Curr. Sci. Bangalore 9: 327-328.

Kim, I., \& G. D. Carr. 1990. Cytogenetics and hybridization of Portulaca in Hawaii. Syst. Bot. 15: 370-377.

Kindberg, N.C. Monographia generis Lepiogonorum. Uppsala. 44 pp. 
, \& D. G. Fisher. 1990. Structural aspects leaves of seven species of Portulaca growing in Hawaii, U.S.A. Canad. Jour. Bot. 1803-1811.

King, C. C. 1978. Distribution of royal catchfly (Silene regia) with special reference to Ohio populations. Ohio Biol. Surv. Biol. Notes 15: 131-141.

Kingsbury, John M. 1964. Poisonous Plants of the United States and Canada. Prentice-Hall, New Jersey. 626 pp.

\section{York.}

. 1965. Deadly Harvest: A guide to Common Poisonous Plants. Holt, Rinchart and Winston, New

Kleopov, J. D. 1936. The systematics and geography of the Caryophyllaceae of the USSR. Zhur. Inst. Bot. AH CCCP 9: 91- 126.

Klingman, G., \& A. D. Worsham. 1965. Knawel (Scleranthus annuus) control in cereal grains. Southern Weed Conf. Proc., 18th Ann. Meeting 157-163.

Kobakhidze, L. A., \& M. 1. Dzanikashvili. 1990. Embryology of Arenaria lychnidea (Caryophyllaceae). Bot. Zhur. 75: 1534-1537.

Kondorskaya, V. R. 1981. Frondous and small-blossom inflorescences in representatives of the family Caryophyllaceae. Bull. Mosk. Obshch. Isp. Pri. Biol. 86(1): 100-115.

Kondratenko, E. S., Z. M. Putieva, \& N. K. Abubakirov. 1982. Triterpene glycosides of plants of the family Caryophyllaceae. Khim. Prirod. Soed. : 417-433.

Kotilainen, M. J. 1947. Stellaria crassifolia Ehrh. cum bulbillis. (In Finnish.) Memo. Soc. pro Fauna et Flora Fenn. 23: 3.

Kovats, D., \& J. Szujko-Lacza. 1979. Distribution and diversity of the Hungarian Spergularia species (Caryophyllaceae). Stud. Bot. Hungarica 13: 57-73.

Kowal, T. 1961. Morphology and anatomy of the seeds in Portulacaceae. Rchb. Monogr. Bot. 12: 3-47.

- 1966. Systematic studies on the seeds of the genera Delia Dum., Spergula L., and Spergularia Presl. Monogr. Bot. 21. 245-270.

Kowal, T., \& H. Wojterska. Systematic studies on the seeds of the genus Dianthus L. Monogr. Bot. 21: 271-297.

Kozhanchikov, V. I. 1967. Morpholgical seed characters in Caryophyllaceae and the possible pathways of their evolution. Bot. Zhur. 52: 1277-1286.

1968. The method of investigation of the clinal variation (as illustrated by the example of the morphological seed characters in the family Caryophyllaceae). Bot. Zhur. 53: 952-960.

Kraft, E. 1917. Experimentelle und entwicklungsgeschichtliche Untersuchungen an Caryophyllaceenblüten. Flora 109: 283-356.

Kruckeberg, A. R. 1954. Chromosome numbers in Silene (Caryophyllaceac): 1. Madroño 12: 238-246. 1955. Insterspecific hybridizations of Silene. Am. Jour. Bot. 42: 373-378.

1960. Chromosome numbers in Silene (Caryophyllaceac): II. Madroño 15:205-215.

1961. Artifical crosses involving western North American Silenes. Brittonia 13: 305-333.

1962. Intergeneric hybrids in the Lychnideae (Caryophyllaceac). Brittonia 14: 311-321.

1962. Artificial crosses involving eastern North American Silenes. Brittonia 16: 95-105.

Kügler, H. 1955. Einführung in die Blütenökologic. Stuttgart. 278 pp.

Lambinon, J. 1981. (599) Proposition de rejet Spergularia media (L.) C. Presl, Fl. Sic. 1: 161. 1826 (Caryophyllaceae). Taxon 30: 364.

Lampe, K. F., \& R. Fagerström. 1968. Plant Toxicity and Dermatitis. A Manual for Physicians. Williams \& Wilkins, Baltimore. 231 pp.

, \& M. A. McCann. 1985. AMA Handbook of Poisonous and Injurious Plants. Amer. Med. Assoc., Review Press, Chicago. 432 pp.

Landry, G. P., W. D. Reese, \& C. M. Allen. 1988. Stellaria parva Pedersen, new to North America. Phytologia 64: 497.

Larson, G. E. Caryophyllaceae. 1986. pp. 192-214. In: Great Plains Flora Association. Flora of the Great Plains. Lawrence, Kansas. viii + 1392 pp.

Latrou, G. 1985. Petrorhagia grandiflora sp. nov. (Caryophyllaceac) from Grcece. Nordic Jour. Bot. 5: 441-445. Laursen, F. 1971. Natlinurt (Silene noctiflora), en "ny" ukrudtsart i Danmark. Ugreskr. Agron. 116: 306-313. Lawrence, G. H. M. 1953a. Keys to cultivated plants. 1. The cultivated spccics of Gypsophila. Bailcya 1: 16-18. . 1953b. Keys to cultivated plants 2. The cultivated species of Lychnis. Bailcya 1: 105-111, 114. 
Lebel, E. 1869. Revision du genre Spergularia. Les Spergulaires francaises et 2 espéces des Canaries. Mem. Soc. Imp. Acad. Cherbourg 14: 17-48.

Lebrun, J. 1965. Le mouvement d'ouverture et de fermeture des fleurs chez diverses Portulacacées. Bull Soc. Bot. Belg. 99: 19-35.

Ledebour, C. F. 1842. Sileneae. In: Flora Rossica. 1: 273-288, 300-337.

Legrand, C. D. 1943. El genero Spergularia in Uruguay. Com. Bot. Mus. Hist. Nat. Montevideo 1(9): 1-12. 1962. Las especies Americanas de Portulaca. Anal. Mus Hist. Nat. Montevideo 7: 1-147. 29 pls.

Lehr, J. H. 1963. A new color form of Dianthus armeria. Bull. Torrey Bot. Club 90: 206.

Lemperg, F. 1936. Studies in the perennial species of the genus Dianthus L. .- I. Acta Horti Gothob. 11: 71-134.

Leonard, J. 1985. Combinaisons nouvelles dans le genre Vaccaria Wolf (Caryophyllaceae). Bull. Jard. Bot. Bruxelles 55: 297-299.

Leonhardt, R. 1951. Phylogenetisch-systematische Betrachtungen. II. Gedanken zur systematischen Stellung, bzw. Gliederung einiger Familien der Choripetalen. Osterr. Bot. Zeitschr. 98: 1-43.

Leslie, A. C. (compiler). 1983. The International Dianthus Register. ed. 2, London. 586 pp.

Levesque, C. M. 1981. Taxonomic implications of seed morphology of Arenaria and Minuartia (Caryophyllaceae). (Abstr.) Bot. Soc. Am. Misc. Ser. Publ. 160: 73.

Lewis, W. H. 1962. Aneusomaty in aneuploid populations of Claytonia virginica. Am. Jour. Bot. 49: 918-928. 1967. Cytocatalytic evolution in plants. Bot. Rev. 33: 105-115.

1970. Extreme instability of chromosome numbers in Claytonia virginica. Taxon 19: 180-182.

1976. Temporal adaptation correlated with ploidy in Claytonia virginica. Syst. Bot. 1: 240-347.

, \& M. P. F. Elvin-Lewis. 1977. Medical Botany. Plants Affecting Man's Health. Wiley \& Sons,

Toronto. $515 \mathrm{pp}$.

. R. Oliver, \& Y. Suda. 1967. Cytogeography of Claytonia virginica and its allies. Ann Missouri Bot. Gard. 54: 153-171.

, \& J. C. Semple. 1977. Geography of Claytonia virginica cytotypes. Am. Jour. Bot. 64: 1078-1082.

, \& Y. Suda. 1968. Karyotypes in relation to classification and phylogeny in Claytonia. Ann.

Missouri Bot. Gard. 55: 64-67.

, Y. Suda \& B. MacBryde. 1967. Chromosome numbers of Claytonia virginica in the St. Louis Missouri area. Ann. Missouri Bot. Gard. 54: 147-152.

Link, H. F. 1831. Handbuch zur Erkennung der Nützbarsten und am häufigsten vorkommenden Gewächse, Berlin. 2: iii +533 pp.

Lister, G. 1884. On the origin of the placenta in the tribe Alsineae of the order Caryophylleae. Bot. Jour. Linn. Soc. 20: 423-429.

Liston, A. 1986. A new species of Petrorhagia (Caryophyllacaeae). Candollea 41: 179-181.

Litvinenko, V. I., V. N. Darmograi, P. E. Krivenchuk, \& I. G. Zoz. 1969. Phenolic compounds of some species of Gypsophila L. Rastitel'nye Resursy 5: 369-379.

Longevialle, M. 1966. Embryogenie des Caryophyllacees. Developpement de l'embryon chez le Arenaria controversa Boiss. Compt. Rend. Acad., Paris D 263: 1205-1208. (and similar papers)

Lonn, M., \& H. C. Prentice. 1990. Mosaic variation in Swedish Petrorhagia prolifera (Caryophyllaceae): the partitioning of morphometric and electrophoretic diversity. Jour. Linn. Soc. Bot. 41: 353-373.

Lonsing, A. 1939. Über einjahrige europaische Cerastium-Arten aus der Verwandtschaft der Grüppen "Ciliatopetala" Fenzl und "Cryptodon" Pax. Repert. Sp. Nov. 46: 139-165.

Lopez-Gonzalez, G., \& G. Nieto-Feliner. 1990. Comments on the taxonomic treatment of Arenaria Section Plinthine (Caryophyllaceac) by D. J. Goyder. Bot. Jour. Linn. Soc. 102: 1-8.

Löve, A. 1974. Cytotaxonomy of Spanish plants. III. Dicotyledons: Salicaceae - Rosaceae. Lagascalia 4: 3-32. , \& D. Löve. 1965. Taxonomic remarks on some American alpine plants. Univ. Colo. Stud. D. 17.

$43 \mathrm{pp}$.

1975a. Cytotaxonomical Atlas of the Arctic Flora. Vaduz. xxiii +598 pp.

1975b. Nomenclatural notes on arctic plants. Bot. Notis. 128: 497-523.

1976. Nomenclatural notes on Arctic plants. Bot. Not. 128: 497- 523. 
, \& E. Kjellquist. 1972. Cytotaxonomical vindication of the genus Conosilene. Jour. Indian Bot.

Soc. 50A: 366-376.

Löve, D. 1944. Cytogenetic studies on dioecious Melandrium. Bot. Not. 1944: 125-213.

Love, F. R. 1940. The Caryophyllaceae of Middle Tennessee. Unpubl. M.A. thesis, George Peabody College, Nashville. 134 pp.

Luders, H. 1907. Systematische Untersuchungen über die Caryophyllaceen mit einfachem Diagramm. Bot. Jahrb. 40 Beibl. 91: 1-38.

Lupaeva, L. I. 1964. A tetraploid form of Lychnis chalcedonica L. ull. Glavnogo Bot. Sada 56: 99-101.

Mabry, T. J. 1976. Pigment dichotomy and DNA-RNA hybridization data for Centrospermous families. Pl. Syst. Evol. 126: 79-94.

MacDonald, S. E., \& C. C. Chinnappa. 1988. Patterns of variation in the Stellaria longipes complex: effects of polyploidy and natural selection. Am. Jour. Bot. 75: 1191-1200.

1989. Population differentiation for phenotypic plasticity in the Stellaria longipes complex. Am.

Jour. Bot. 76: 1627-1637.

, \& D. M. Reid. 1984. Studies on the Stellaria longipes complex: phenotypic plasticity. I. Response of stem elongation to temperature and photoperiod. Canad. Jour. Bot. 62: 414-419.

. 1988. Evolution of phenotypic plasticity in the Stellaria longipes complex: comparisons among

cytotypes and habitats. Evolution 42: 1036-1046.

, \& B. G. Purdy. 1987. Population differentiation of the Stellaria longipes complex within

Saskatchewan's Athabasca sand dunes. Canad. Jour. Bot. 65: 1726-1732.

Maguire, B. 1946a. Studies in the Caryophyllaceae. I. Bull. Torrey Bot. Club 73: 326.

. 1946b. Studies in the Caryophyllaceae. II. Arenaria nuttallii and A. filiorum, section Alsine.

Madroño 8: 258-263.

1947. Studies in the Caryophyllaceae. III. A synopsis of the North American species of Arenaria

sect. Eremogone Fenzl. Bull. Torrey Bot. Club 74: 38-56.

. 1950. Studies in the Caryophyllaceae - IV. Rhodora 52: 233-245.

46: $493-511$.

1951. Studies in the Caryophyllaceae. V. Arenaria in America north of Mexico. Am. Midl. Nat.

1952. Caryophyllaceac. In: N. L. Britton \& A. Brown. Illustrated Flora of the Northeastern United States and Adjacent Canada. Hafner Publ., New York. 2: 118-145.

Magulaev, A. 1982. The number of chromosomes of the species of Asteraceae, Caryophyllaceae and Plantaginaceae of the North Caucasus. Biol. Nauki (Moscow) 11(227): 74-79.

Mahal, B. E., \& F. H. Bormann. 1978. A quantitative description of the vegetative phenology of herbs in a Northern Hardwood Forest. Bot. Gaz. 139: 467-481.

Mahran, G. H., S. I. Balboa, \& G. A. El-Hossary. 1975a. Macro and micromorphology of the flowers of Saponaria officinalis L. grown in Egypt. Egypt Jour. Pharm. Sci. 16: 1-22.

. 1975b. Macro and micromorphology of the fruit of Saponaria officinalis L. grown in Egypt. Egypt. Jour. Pharm. 16: 23-34.

Mangalan, S., M. Daniel \& S. D. Sabnis. 1989. Nutritional and phytochemical aspects of some vegetables of Centrospermae. Jour. Econ. Taxon. Bot. 13: 227-230.

Marroquin, A. S. \& H. A. Winter. 1940. Un estudio morfologico de la plantula de Claytonia virginica. Ann. Esc. Nac. Cienc. Biol. Mex. 2: 191-215.

Marsden-Jones, E. M., \& W. B. Turrill. 1957. The Bladder Campions. London. ix + 378 pp.

. 1960. Researches on Silene maritima and S. vulgaris. XXXV. Plants from a serpentine area in Bosnia. Kew Bull. 14: 241-244.

Martin, D. 1991. Endangered and threatened wildlife and plants; endangered status for the plant Silene polypetala (Fringed campion). Federal Register 56: 1932-1936.

Mastenbroek, O., J. van Brederode, G. J. Niemann, \& G. van Nigtevecht. 1981. Changes in isoenzyme patterns during the ontogeny of Silene alba. Biochem. Physiol. Pfl. 176: 584-589.

Mattfeld, J. 1921. Zur Kenntnis der Phylogenie unterständiger früchtknöten bei den Caryophyllaceen. Ber. Deutsch. Bot. Ges. 39: 275-280. 
. 1922a. Beitrag zur Kenntnis der systematischen Gliederung und geographischen Verbreitung der Gattung Minuartia. Bot. Jahrb. Biebl. 127: 13-63.

. 1922b. Geographisch-genetische Untersuchungen über die Gattung Minuartia (L.) Hiern. Rep. Sp. Nov. Beih. 15: 1-228, Karte 1-12.

Matthews, J. F., \& P. A. Levins. 1985. The genus Portulaca in the southeastern United States. Castanea 50: 96-104.

- 1986. The systematic significance of seed morphology in Portulaca (Portulacaceae) under scanning electron microscopy. Syst. Bot. 11: 302-308.

305.

, \& D. W. Ketron. 1991. Two new combinations in Portulaca (Portulacaceae). Castanea 56: 304-

Matzke, E. B. 1930. A morphologic study of the variations in Stellaria aquatica with special reference to symmetry and sterility. Bull. Torrey Bot. Club 56: 471-534.

- 1932. Flower variations and symmetry patterns in Stellaria media, and their underlying significance. Am. Jour. Bot. 19: 477-507.

Maurer, E. S. 1957. The essentials of perfume compounding. New Series: the natural products. 15. The Caryophyllaceae. Soap, Perfumery \& Cosmetics 30: 316-317, 410-411.

McCormick, J. F., J. R. Bozeman, \& S. Spongberg. 1971. A taxonomic revision of granite outcrop species of Minuartia (Arenaria). Brittonia 23: 149-160.

McNeill, J. 1962. Taxonomic studies in the Alsinoideae: I. Generic and infra-generic groups. Notes Bot. Gard. Edinb. 24: 79-155.

. 1963. Taxonomic studies in the Alsinoideae: II. A revision of the species in the Orient. Notes Bot. Gard. Edinb. 24: 241-404.

. 1969. New species of Minuartia (Caryophyllaceae). Notes Bot. Gard. Edinb. 29: 325-327.

1973. Gypsophila and Stellaria: an unexpected problem in generic delimitation. Notes Bot. Gard.

Edinb. 32: 389-395.

1977. The biology of Canadian weeds. 25. Silene alba (Miller) E. H. L. Krause. Canad. Jour. Plant. Sci. 57: 1103-1114.

. 1978. Silene alba and $S$. dioica in North America and the generic delimitation of Lychnis, Melandrium, and Silene (Caryophyllaceae). Canad. Jour. Bot. 56: 297-308.

1243-1253.

1980a. The biology of Canadian weeds. 46. Silene noctiflora L. Canad. Jour. Plant. Sci. 60:

1980b. The delimitation of Arenaria (Caryophyllaceae) and related genera in North America,

with 11 new combinations in Minuartia. Rhodora 82: 495-502.

, \& I. J. Bassett. 1974. Pollen morphology and the infrageneric classification of Minuartia

(Caryophyllaceae). Canad. Jour. Bot. 52: 1225-1231.

, \& C. W. Crompton. 1978. Pollen dimorphism in Silene alba. Canad. Jour. Bot. 56: 1280-1286.

, \& J. N. Findlay. 1972. Introduced perennial species of Stellaria in Quebec. Nat. Canad. 99: 59-60.

, \& N. C. Majumdar. 1980. A new species of Arenaria subgenus Odontostemma from Tibet, with

a review of the status of the genus Gooringia (Caryophyllaceae). Jour. Linn. Soc. Bot. 80: 371-378.

, \& H. Prentice. 1981. Silene pratensis (Rafn) Godron \& Gren., the correct name for white

campion or white cockle (Silene alba (Mill.) E. H. L. Krause, nom. illeg.). Taxon 30: 27-32.

McQuown, F. R. 1955. Pinks; Selection \& Cultivation. London. 176 pp.

Melzheimer, V. 1975. Pollensystematische Untersuchunge in der Gattung Silene L. (Caryophyllaceae). Bot. Jahrb. 95: 215-225.

- 1977. Biosystematische Revision einiger Silene-Arten (Caryophyllaceae) der Balkanhalbinsel

(Griechenland). Bot. Jahrb. 98: 1-92.

. 1979. Biosystematic reseearches in some groups of the genus Silene from the Balkan Peninsula

(Greece). Webbia 34: 517-522.

. 1980. Revision einiger balkanischer Arten von Silene sect. Inflatae (Caryophyllaceae). Bot. Jahrb.

101: $153-190$.

Mercier, S., C. Gervais, M. Grantner \& G. Roy. 1990. Chromosomes of Claytonia caroliniana Michx. in natural

forest and in two electric power line corridors. Nat. Canad. 117: 13-18. 
Merrill, E. D. 1938. A critical consideration of Houttuyn's new genera and new species of plants, 1773-1783. Jour. Arnold Arb. 19: 291-375.

Merxmuller, H. 1950. Untersuchung über eine alpine Cerastien-gruppe. Ber. Bayer. Bot. Ges. 28: 219-238. Meyer, K. I. 1962. On the embryology of Coronaria flos-cuculi (L.) R. Br. Bot. Zhur. 47: 847-852.

Mii, M., \& R. Iwasa. 1972. Karyological studies on three species of Portulaca. Jap. Jour. Breed. 22: 114-118.

Milby, T. H. 1980. Studies in the floral anatomy of Claytonia virginica (Portulacaceac). Am. Jour. Bot 67: 1046-1050.

Miller, J. M. 1979. Phenotypic variation, distribution and relationships of diploid and tetraploid populations of the Claytonia perfoliata complex (Portulacaceac). Syst. Bot. 3: 322-341.

Mitchell, R. S. 1986. A Checklist of New York State Plants. N.Y. State Mus. Bull. 458. 272 pp.

, \& G. C. Tucker. 1991. Sagina japonica (Sw.) Ohwi (Caryophyllaceac), an overlooked adventive in the northeastern United States. Rhodora 93: 192-194.

, \& L. J. Uttal. 1969. Natural hybridization in Virginia Silene (Caryophyllaceac). Bull. Torrey Bot. Club 96: 544-549.

Miyanishi, K. \& P. B. Cavers. 1980. The biology of Canadian weeds. 40. Portulaca oleracea L. Canad. Jour. PI. Sci. 60: 953-963.

. 1963. The genus Cerastium in Japan. Sci. Rep. Tohoku Univ. IV. Biol. 29: 277-294.

. 1960. A preliminary revision of the genus Sagina of Japan and its adjacent regions. 1-5 (Critical

studies on Japanese plants 5). Jour. Jap. Bot. 35: 77-82; 103-107; 193-200; 257-260; 335-340.

. 1965a. A conspectus of the genus Stellaria in Japan I. Jour. Jap. Bot. 40: 90-96.

. 1965b. A conspectus of the genus Stellaria in Japan II. Jour Jap. Bot. 40: 250-256.

1965c. Critical studies on Japanese plants, 11: The genus Pseudostellaria Pax in Japan. Bull. Bot.

Surv. India 7: 62-72.

40 pl. Tokyo.

1966. Caryophyllaceac. pp. 79-85. In: H. Hara. The flora of eastern Himalaya. xi + 1-711 pp. +

Mocliono, B. M. 1959. A preliminary note on the placenta of Stellaria media (L.) Vill. and Stellaria graminea L. A possible axial origin of ovula? Acta. Bot. Neerl. 8: 292-303.

Molliard, M., \& R. Echevin. 1936. Secretion intraovarienne chez la nielle (Agrostemma githago L.). Revue Gen. Bot. 48: 81-93. pl. 4-7.

Monachino, J. 1944. Herniaria glabra var. subciliata in New York. Rhodora 46: 22-25.

Monnier, P. 1960a. Biosystematique de quelques Spergularia mediterraneen. Compt. Rend. Acad. Paris 250: 4429-4431.

$117-119$.

1960b. Biosystematique de quelques Spergularia mediterraneen. Compt. Rend. Acad. Paris 251:

1962. Biogeographie et micro-evolution chez Spergularia marginata Kitt. sensu latissimo dans le bassin mediterraneen occidental, Afrique du Nord notament. Revue Cytol. Biol. Vegetales 25: 325-335. -1975a. Systematique du genre Spergularia dans le bassin Mediterraneen occidental (essai de taxinomie synthetique). III. 1. Serie du Spergularia marginata (DC.) Kittel (=groupe Pterospermac). Candollea 30: 121-155.

. 1975b. Systematique du genre Spergularia dans le bassin Mediterraneen occidental (essai de taxinomie synthetique). IIl. 3. Section des "Heterospermae" (=Serie de S. salina). Nat. Monspel. Bot. 25 : 65-87.

Moore, J. A. 1956. Silene virginica in the Gulf States. Rhodora 58: 27-29.

Morton, J. K. 1972a. On the occurrence of Stellaria pallida in North America. Bull. Torrey Bot. Club 99: 95-97. 1972b. Spontancous hybrids between Cerastium tomentosum Linn. and C. an'ense Linn. Rhodora 74: $519-521$.

1984. A new basic chromosome number in the genus Stellaria (Caryophyllaceae). Rhodora 86: 417-419.

1987. Cerastium velutinum Raf. In: K. M. Pryer \& G. W. Argus (eds.) Atlas of the Rare Vascular Plants of Ontario, Part 4. 1 p. Ottawa.

, \& R. K. Rabeler. 1989. Biosystematic studies on the Stellaria calycantha (Caryophyllaceac)

complex. I. Cytology and cytogeography. Canad. Jour. Bot. 67: 121-127. 
Möschl, W. 1936. Über einjahrige europäische Arten der Gattung Cerastium (Orthodon-Fugacia-Leiopetala). Repert. Sp. Nov. 41: 153-163.

. 1938. Morphologie einjahrige europäischer Arten der Gattung Cerastium (Orthodon-Fugacia-Leiopetala). Österr. Bot. Zeitschr. 87: 249-272.

1949. Cerastium semidecandrum Linne, sensu latiore. Mem. Soc. Bot. 5: 5-120

Moss, C. E. 1914. Notes on British plants. I. Sagina saginoides. Jour. Bot. 52: 57-63.

Motten, A. F., D. R. Campbell \& D. E. Alexander. 1981. Pollination effectiveness of specialist and general visitors to a North Carolina, U.S.A., population of Claytonia virginica. Ecology 62: 1278-1287.

Neumayer, H. 1915. Die Gattungsabgrenzung innerhalb der Diantheen. Verh. Zool.-Bot. Ges. Wien 65: 22-24. 72: 53-59.

1923. Die Frage der Gattungsabgrenzung innerhalb der Silenoideen. Verh. Zool.-Bot. Ges. Wien

New, J. K. 1958. A population study of Spergula arvensis. I. Two clines and their significance. Ann. Bot. 22: 457-477. 23: 23-33.

1959. A population study of Spergula arvensis. II. Genetics and breeding behaviour. Ann. Bot.

1961. Biological flora of the British Isles. Spergula arvensis L. (S. sativa Boenn., S. vulgaris Boenn.). Jour. Ecol. 49: 205-215.

. 1978. Change and stability of clines in Spergula arvensis L. (corn spurrey) after 20 years.

Watsonia 12: 137-143.

, \& J. C. Herriott. 1981. Moisture for germination as a factor affecting the distribution of the seedcoat morphs of Spergula arvensis L. Watsonia 14: 323-324.

Niedermyer, R. W., \& J. D. Nalewaja. 1969. Uptake, translocation, and fate of 2,4-D in nightflowering catchfly and common lambsquarters. Weed Sci. 17: 528-532.

Nieto-Feliner, G. 1985. Datos citotaxonomicos sobre Arenaria Sect. Plinthine (Reichenb.) McNeill. Candollea 40: 471-483.

Nieuwland, J. A. 1913. Evactoma. Am. Midl. Nat. 3: 57-59.

Nigtevecht, G. van. 1966a. Genetic studies in dioecious Melandrium. I. Sex-linked and sex-influenced inheritance in Melandrium album and Melandrium dioicum. Genetica 37: 281-306.

.1966b. Genetic studies in dioecious Melandrium. II. Sex determination in Melandrium album and Melandrium dioicum. Genetica. 37: 307-344.

Nilsson, A. 1977. Spontaneous hybrids between Cerastium arvense and Cerastium tomentosum. Sv. Bot. Tidskr. 71: 263-272.

Nilsson, Ö. 1967. Studies in Montia L. and Claytonia L., and allied genera. 3. Pollen Morphology. Grana Palynol. 7: 279-363.

Novak, F. A. 1924. Monograficka studie o Dianthus plumarius (L.). Vestn. Kral. Ceske Spolecnosti Nauk, Tr. Matemat.- Prirod.1923(11): 1-42.

1928a. Monograficka studie o postglacialnich druzich rodu Dianthus ze sekce Plumaria (Opiz).

Vestn. Kral. Ceske Spolecnosti Nauk, Tr. Matemat.-Prirod. 1927(9): 1-100.

. 1928b. Dianthii fimbriati europaei. I. Repert. Sp. Nov. 25: 38-47.

\& J. J. Skvarla. 1977. Pollen Morphology and the Relationship of the Plumbaginaceae,

Polygonaceac, and Primulaceae to the Order Centrospermae. Smiths. Contr. Bot. 37: iii + 64 pp.

Novoplansky, A., D. Cohen, \& T. Sachs. 1990. How Portulaca seeds avoid their neighbors. Oecologia (Heidelburg) 82: 490-493.

Nyananyo, B. L. 1986. A survey of leaf flavonoids in the Portulaceae.Biochem. Syst. Ecol. 14: 633-635. 1987. Taxonomic studies in the genus Portulaca (Portulacaceae). Feddes Repert. 98: 399-402. 1988a. The systamatic significance of seed morphology and anatomy in the Portulacaceae (Centrospermae). Fol. Geobot. Phytotax.

- 1988b. Leaf anatomical studies on the Portulacaceae (Centrospermae), with regard to photosynthetic pathways. Fol. Geob. Phytotax. 99-101.

1992. Pollen morphology in the Portulacaceae (Centrospermae). Fol. Geobot. Phytotax., Praha.

27: $387-400$. 
Nygren, A. 1957. A fertile hybrid Lychnis flos-cuculi and Melandrium rubrum and its sex segregating offspring. Kungl. Lantbruks. Ann. 23: 413-421.

Odum, S. 1965. Germination of ancient seeds. Dansk Bot. Arkiv. 24(2): 1-70.

Okuyama, S. 1951. Silene antirrhina L., a new naturalized plant in Prov. Shinana, from U. S. A. Jour. Jap. Bot. 26: 254-255.

Pal, S., \& Y. S. Murty. 1972. Structure and development of female gametophyte and embryo in Stellaria aquatica Scop. Jour. Indian Bot. Soc. 51: 232- 234.

. 1974a. Studies on the nodal and floral anatomy of some species of Stellaria L. Jour. Indian Bot. Soc. 53: $100-110$.

. 1974b. A contribution to the embryology of Stellaria paniculata. Edgew. Jour. Indian Bot. Soc. 53: $288-292$.

Palmer, E. J., \& J. A. Steyermark. 1950. Notes on Geocarpon minimum Mackenzic. Bull. Torrey Bot. Club 77 : 268-273.

Pant, D. D., \& P. F. Kidwal. 1968. Structure and ontogeny of stomata in some Caryophyllaceac. Jour. Linn. Soc. Bot. 60: 309-314.

Pax, F. 1927. Zur Phylogenie der Caryophyllaceac. Bot. Jahrb. 61: 223-241. 1934. Portulacaceac. In: A. Engler \& H. Harms. Nat. Pflanzenfamilien. (ed.) 2, Bd. 16c: 234-262. 275-364. , \& K. Hoffmann. 1934. Caryophyllaceae. In: A. Engler \& H. Harms, Nat. Pflanzenfam. ed. 2. 16c:

Payer, J. B. 1854-1857. Traite d'organogenie comparée de la fleur. Paris. Texıe: viii +749 pp. Atlas: viii pp. $+154 \mathrm{pl}$.

Payne, M. A. 1933. Morphology and anatomy of Mollugo verticillata L. Univ. Kansas Sci. Bull. 21: 399-419. . 1935. The flower and seed of Mollugo verticillata. Univ. Kansas Sci. Bull. 22: 5-25.

Pedersen, T. M. 1961. New species of Hydrocleis, Scirpus, and Stellaria. Bot. Tidskr. 57: 38-48.

Penzig, O. 1890. Pflanzen-Teratologie. Geneva, 1: xx + 540 pp.

Perring, F. H., \& P. D. Sell. 1967. Arenaria serpyllifolia L. In: P. D. Sell. Taxonomic and nomenclatural notes on the British flora. Watsonia 6: 294.

, \& C. Farrell. 1977. British Red Data Books: 1. Vascular Plants. London. 98 pp.

Peterson, D. 1936. Stellaria-Studien. Zu Zytologie, Genetik, Okologie und Systematik der Gattung Stellaria, insbesondere der Media-Gruppe. Bot. Not. 1936: 281-419.

Peterson, S. R. 1969. Biology of the mouse-ear chickweed, Cerastium vulgatum. Mich. Bot. 8: 151-157.

Petria, E. 1971. Contributions to the embryological knowledge of Centrospermales. I. Fam. Caryophyllaceae. Development of the female gametophyte and embryogeny in Cerastium tomentosum. Anal. Univ. Bucuresti Biol. Veg. 20: 109-121.

Philipp, M. 1972. The Stellaria longipes group in N. W. Greenland. Cytological and morphological investigations. Bot. Tidsk. 67: 64-75.

1975. Flower biology of Stellaria longipes. Bot. Tidsk. 69: 239-244.

Pickens, A. L., \& M. C. W. Pickens. 1960. Variations in Quercus, Silene, and Lamium. Castanea 25: 125.

Piehl, M. A. 1962. Holosteum umbellatum L., an angiosperm new to Michigan. Rhodora 64: 222-225.

Plouvier, V. 1954. Sur la presence de pinitol chez les Caryophyllacees et quelques plantes de familles voisines. Compt. Rend. Acad. Paris 239: 1678-1680.

1957. Sur la recherche du pinitol chez quelques Caryophyllacees Magnoliacees et plantes de familles voisines. Compt. Rend. Acad. Paris 244: 382-385.

1962. Nouvelles recherches de cyclitols dans quelques groupes botaniques: le L-inositol des

Composées, le D-pinitol des Legumineuses. Compt. Rend. Acad. Paris 255: 1770-1772.

1984. Recherche du dianthoside chez quelques Caryophyllacees. Structure de deux glucosides

pyranniques isoles des Saponaria et Dianthus. Compt. Rend. Acad. Paris 111 299: 97-100.

, M. T. Martin, \& J. P. Brouard. 1986. Two pyran type glycosides from Saponaria and Dianthus.

Phytochemistry 25: 546-548.

Poellinitz, K. von. 1934. Versuch einer Monographie der Gattung Portulaca L. Repert. Sp. Nov. 37: 240-320. . 1941. Zur Kenntnis der Gattung Portulaca. Feddes Repert. Spec. Nov. 50: 107-112.

Poelt, J. Wilhelm Möschl - ein Nachruf. Mitt. Naturwiss. Ver. Steiermark 112: 9-13. 
Ponzo, A. 1935. Le stipule di Spergularia rubra Pers. Nuovo Gior. Bot. Ital. 42: 677-680.

Porsild, A. E. 1963. Stellaria longipes Goldie and its allies in North America. Natl. Mus. Canada Bull. 186: $1-35$.

Prentice, H. C. 1978. Experimental taxonomy of Silene section Elisanthe (Caryophyllaceae): crossing experiments. Jour. Linn. Soc. Bot. 77: 203- 216.

1979. Numerical analysis of infraspecific variation in European Silene alba and $S$. dioica (Caryophyllaceae). Jour. Linn. Soc. Bot. 78: 181-212.

1984. The sex ratio in a dioecious endemic plant Silene diclinis. Genetica 64: 129-133.

-1986. Climate and clinal variation in seed morphology of the white campion, Silene latifolia (Caryophyllaceae). Jour. Linn. Soc. Bot. 27: 179-189.

156: 5-11.

1987. Analysis of the clinal variation pattern in Silene latifolia pollen morphology. Pl. Syst. Evol.

Pringle, J. S. 1976. Gypsophila scorzonerifolia (Caryophyllaceae), a naturalized species in the Great Lakes Region. Mich. Bot. 15: 215-219.

Pritchard, H. N. 1964a. A cytochemical study of embryo sac development in Stellaria media. Am. Jour. Bot. 51: $371-378$. 472-479.

1964b. A cytochemical study of embryo development in Stellaria media. Am. Jour. Bot. 51:

Puech, S. 1968. Ètude biosystematique de quelques taxons de la bordure cevenole calcaire de la reion d'Anduze (Gard) (I). Nat. Monspel. Bot. 19: 115- 166.

Purdy, C. 1935. West American silenes. Natl. Hort. Mag. 14: 294-296.

Rabeler, R. K. 1980. Petrorhagia prolifera, a naturalized species in Michigan. Mich. Bot. 19: 83-88.

. 1981. Gypsophila muralis. Is it naturalized in Michigan? Mich. Bot. 20: 21-26.

1984. Notes on nomenclature within Petrorhagia (Caryophyllaceae). Taxon 33: 714- 716.

1985a. Isonyms of Petrorhagia obcordata (Caryophyllaceae). Taxon. 34: 293.

. 1985b. Petrorhagia (Caryophyllaceae) of North America. Sida 11: 6-44.

. 1986. Revision of the Stellaria calycantha (Caryophyllaceae) complex and taxonomic notes on

the genus. Ph.D. Dissertation, Mich. State Univ. xviii +449 pp. (Unpubl.)

. 1988a. Noteworthy collections. Michigan. Cerastium glomeratum Thuill. and Gypsophila muralis

L. Mich. Bot. 27: 91-92.

. 1988b. Eurasian introductions to the Michigan flora. IV. Two additional species of Caryophyll-

aceae in Michigan. Mich. Bot. 27: 85-88.

. 1990. Noteworthy collections. West Virginia. Cerastium brachypetalum. Castanea 55: 212.

110-111.

1991. Cometeae, the correct name for the tribe Pterantheae (Caryophyllaceae). Taxon 40:

. 1992a. (1034) Proposal to conserve 2490 Silene L. against Lychnis L. Taxon 41: 126-128.

1992b. A new combination in Minuartia (Caryophyllaceae). Sida 15: 95-96.

1993a. Infrageneric nomenclature: corrections in the Caryophyllaceae. Contr. Univ. Mich. Herb.

19: $149-164$.

. 1993b. The occurrence of anther smut, Ustilago violacea, on Stellaria borealis (Caryophyllaceae)

in North America. Contr. Univ. Mich Herb. 19: 165-169

, \& C. T. Bryan. 1990. Montia linearis (Portulacaceae), new to Mississippi. Sida 14: 310-311.

, \& J. W. Thieret. 1988. Comments on the Caryophyllaceae of the southeastern United States.

Sida 13: $149-156$.

Ramji, M. V. 1975. Histology of growth with regard to embryos and apical meristems in some angiosperms.

1. Embryogeny of Stellaria media. Phytomorphology 25: 131-145.

. 1976. Histology of growth with regard to embryos and apical meristems in some angiosperms.

11. Differentiation of apical meristems in Stellaria media. Phytomorphology 26: 124-135.

Ratter, J.A. 1964. Cytogenetic studies in Spergularia: I. Cytology of the old world species. Notes Bot. Gard. Edinb. 25: 293-303.

-1965a. Cytogenetic studies in Spergularia: 11. An attempt to discover cytogenetic relationships of

some species. Notes Bot. Gard. Edinb. 26: 203-223. 
. 1965b. Cytogenetic studies in Spergularia: 111. Some interspecific hybrids involving S. marina (L.)

Griseb. Notes Bot. Gard. Edinb. 26: 224-236.

. 1968. The chromosome numbers of Spergula fallax and Hypertelis bowkeriana. Notes Bot. Gard.

Edinb. 28: 189-190.

. 1969a. Cytogenetic studies in Spergularia: IV. Some further interspecific hybrids. Notes Bot.

Gard. Edinb. 29: 213-223.

. 1969b. Cytogenetic studies in Spergularia: V. Some interspecific hybrids involving S. media (L.)

C. Presl. Notes Bot. Gard. Edinb. 29: 225-232.

. 1972. Cytogenetic studies in Spergularia: VI. The evolution of true breeding, fertile tetraploids

from a triploid interspecific hybrid. Notes Bot. Gard. Edinb. 32: 117-125.

. 1973a. Cytogenetic studies in Spergularia: VII. Cryptic speciation in S. media (L.) C. Presl and

S. marina (L.) Griseb. Notes Bot. Gard. Edinb. 32: 291-296.

. 1973b. Cytogenetic studies in Spergularia: VIII. Barriers to the production of viable interspecific

hybrids. Notes Bot. Gard. Edinb. 32: 297-301.

34: 411-428.

1976. Cytogenetic studies in Spergularia: IX. Summary and conclusions. Notes Bot. Gard. Edinb.

1986. Spergula and Spergularia in the British Isles. Notes Bot. Gard. Edinb. 43: 283-297.

Raulston, J. C., S. L. Poe, F. J. Marousky, \& W. T. Witte. 1973. Gypsophila production in Florida. Florida

Univ. Ext. Florida Flower Grower 10(1): 1-8.

Raven, P. H. 1965. On the status of "Tunica prolifera" in California. Leafl. West. Bot. 10: 179.

Rechinger, K. H. 1963. Die Caryophyllaceen-Gattung Pleioneura Rech. f. und ihre systematische Stellung. Ann.

Naturh. Mus. Wien 66: 45-50. [with a key to Dianthinae in English]

Reese, C. S. L., \& E. M. Barrows. 1980. Co-evolution of Claytonia virginica (Portulacaceae) and its main native

pollinator, Andrena erigeniae (Andrenidae). Proc. Ent. Soc. Wash. 82: 685-694.

Reichenbach, L. 1871. Prolusio de Scleranthus. Dresden.

. 1872. Vorläufiger Blick auf Scleranthus. Österr. Bot. Zeitschr. 22: 111-115.

Rettig, J.H., H.D. Wilson, \& J.R. Manhart. 1990. Systematics of the Caryophyllidae, using rbcL gene sequence data. Am. Jour. Bot. 77 (6,supp.): 117-118.

Reveal, J. L. 1991. Two previously unnoticed sources of generic names published by John Hill in 1753 and

1754-1755. Bull. Mus. Hist. Nat., Paris IV, sect. B, Adansonia 13: 197-239.

Reznicek, A. A., \& D. M. Britton. 1971. Chromosome studies in thespring beauties, Claytonia, in Ontario. Mich. Bot. 10: 51- 62 .

Rhoads, A. F., A. Newbold, R. H. Mellon, \& R. E. Latham. 1985. Montia chamissoi rediscovered along the Delaware River in Wayne County, Pennsylvania. Bartonia 51: 77.

Richardson, P. M. 1978. Flavonols and C-glycosylflavonoids of the Caryophyllales. Biochem. Syst. Ecol. 6: 283-286.

Rizvi, S., T. N. Khoshoo, \& M. Pal. 1971. Cytoptypes within the annual ornamental Portulaca. Caryologia 25: 9-15.

Roach, D. A., \& P. J. Marchand. 1984. Recovery of alpine distrubances, early growth, and survival in populations of the native species Arenaria groenlandica, Juncus trifidus, and Potentilla tridentata. Arct. Alp. Research 16: 37-44.

Robinson, B. L. 1893. The North American Sileneae and Polycarpeae. Proc. Am. Acad. 28: 124-155.

. 1894. The North American Alsineae. Proc. Am. Acad. 29: 273-313.

1904. The identity of Anychia dichotoma. Rhodora 6: 50-53.

Rocen, T. 1927. Zur Embryologie der Centrospermen. Dissertation, Univ. Uppsala. 184 pp.

Rodman, J. E. 1990. Centrospermae revisited, part I. Taxon 39: 383-393.

. M. K. Oliver, R. R. Nakamura, J. U. McClammer Jr., \& A. H. Bledsoe. 1984. A taxonomic analysis and revised classification of Centrospermae. Syst. Bot. 9: 297-323.

Rohrbach, P. 1868a. Conspectus systematicus specierum generis silenes. Ann. Sci. Nat. Bot. V. 8: 369-382. . 1868b. Morphologie der gattung Silene. Leipzig. 52 pp.

1869. Monographie der gattung Silene. Leipzig. 249 pp.

. 1869-1870. Synopsis der Lychnideen. Linnaea 36: 170-270. 
1872. Beiträge zur Systematik der Caryophyllinen. III. Linnaea 37: 183-312.

Rohweder, H. 1934. Beiträge zur Systematik und Phylogenie des genus Dianthus unter Berücksichtigung der karyologischen Verhältnisse. Bot. Jahrb. 66: 249-368 + Taf. 1-3.

59: $1-88$.

1939. Weitere Beiträge zur Systematik und Phylogenie der Caryophyllaceen. Beih. Bot. Centr.

1943. Über die Bedeutung der Karyologie der Caryophyllaceae. Lilloa 9: 203-210.

Rohweder, O. 1967. Centrospermen-Studien 3. Blütenentwicklung und Blütenbau bei Silenoideen (Caryophyllaceae). Bot. Jahrb. 86: 130-185. + taf. 8-12.

. 1970. Centrospermen-Studien 4. Morphologie und anatomie der Blüten, Fruchte und Samen bei Alsinoideen und Paronychioideen s. lat. (Caryophyllaceae). Bot. Jahrb. 80: 201-271.

, \& K. Urmi-Konig. 1975. Centrospermen-Studien 8. Beiträge zur Morphologie, Anatomie und systematischen Stellung von Gymmocarpos Forsk. und Paronychia argentea Lam. (Caryophyllaceae). Bot. Jahrb. 96: 375-409.

Rollins, R. C. 1958. Orange-yellow-flowered Claytonia virginica. Rhodora 60: 258-259.

Ross, R. 1966. The generic names published by N. M. von Wolf. Acta Bot. Neerl. 15: 147-161.

Rossbach, R. P. 1940. Spergularia in North and South America. Rhodora 42: 57-83; 105-143; 158-193; $203-213$.

Rossi, B. D., \& J. P. Zryd. 1990. New phenotype patterns regenerated by genetic instabilities in Portulaca grandiflora Hook. (Abstr.) Experientia: 46: A64.

Rossler, W. 1950. Die Scleranthus-Arten Reichenbachs. Anal. Naturh. Mus. Wien 57: 97-129.

. 1954. Neues aus dem Scleranthus-Nachlass Reichenbach. Phyton (Austria) 5: 222-227.

1955. Die Scleranthus-Arten Osterreichs und seiner Nachbarlander. Osterr. Bot. Zeitschr. 102:

$30-72$.

Roth, I. 1963. Histogenese und morphologische Deutung der Zentralplazenta von Cerastium. Bot. Jahrb. 82: 100-118.

Rothwell, N. V. 1959. Aneuploidy in Claytonia virginica. Am Jour. Bot. 46: 353-360.

, \& J. C. Kump. 1965. Chromosome numbers in populations of Claytonia from the New York metropolitan area. Am. Jour. Bot. 52: 403-407.

Runemark, H. 1980. Studies in the Aegean Flora XXIII. The Dianthus fruticosus complex. Bot. Not. 133: 475-490.

Rutishauser, R. 1981. Blattstellung und Sprossentwicklung bei Blütenpflanzen unter besonderer Berücksichtigung der Nelkengewächse (Caryophyllaceen s.l.). Diss. Bot. 62: 127 pp.

Rydberg, P. A. 1932. Portulacaceae. North Am. Flora 21: 279-336.

Saatov, Z., M. Gorovits, \& N. Abubakirov. 1988. Phytoecdysteroids of plants of the genus Silene. XVI. Viticosterone E 22-O-benzoate from Silene wallichiana. Khim. Prir. Soed.: 546-549.

Salisbury, E. J. 1958. Spergularia salina and Spergularia marginata and their heteromorphic seeds. Kew Bull. 13: $41-51$.

Salman, A. H. P. M., G. van Ommering, \& W. B. de Voogd. 1977. Cerastium holosteoides Fries (s.s.) en C. fontanum Baumg. subsp. triviale (Link) Jalas in Nederland. Gorteria 8: 99-108.

Salt, T. A., \& J. H. Adler. 1986. Dominance of 7-sterols in the family Caryophyllaceae. Lipids 21: $754-758$.

Sandbrink, J. M., L. J. N. M. Geurts, T. W. J. Gadella, \& J. van Brederode. 1989. Chloroplast DNA variation in Silene section Elisanthe demonstrates Silene noctiflora L. is not properly classified. Bioch. Syst. Ecol. 17: 539-549.

,A. C. van Brüggen, \& J. van Brederode. 1990. Patterns of infraspecific chloroplast DNA variation in species of Silene sect. Elisanthe. Bioch. Syst. Ecol. 18: 233-238.

Sansome, F. W. 1938. Sex determination in Silene otites and related species. Jour. Genet. 35: 387-396.

Schaper, P. 1936. Beiträge zur mikroskopischen Diagnostik der wichtigsten Caryophyllaceensamen. Landw. Vers. 125: 1-100.

Scharfetter, R. 1912. Die Gattung Saponaria subgenus Saponariella Simmler. Eine pflanzengeographisch-genetische Untersuchung. Osterr. Bot. Zeitschr. 62: 1-8, 74-88, 109-114.

Schemske, D. W. 1977. Flowering phenology and seed set in Claytonia virginica (Portulacaceae). Bull. Torrey Bot. Club 104: 254-263. 
M. F. Wilson, M. N. Melampy, L. J. Miller, L. Verner, K. M. Schemske, \& L. B. Best. 1978. Flowering ecology of some spring woodland herbs. Ecology 59: 351-366.

Schermerhorn, J. W., \& M. W. Quimby (eds.). 1957. The Lynn Index; a Bibliography of Phytochemistry. Monograph I. Order Centrospermac. Boston. 46 pp.

Schischkin, B. K. 1919. Sur deux genres monotypes de la famille des Caryophyllaceae. Izv. Muz. Kavk. (Bull. Mus. Caucase) 12: 200-208.

1936. Caryophyllaceac. In: B. K. Schischkin (ed.) Fl. USSR 6: 386-870, 880-900.

Schlising, R. A., \& H. H. Iltis. 1962. Preliminary reports on the flora of Wisconsin. No. 46. Caryophyllaceae - Pink Family. Trans. Wis. Acad. 50: 89-139.

Scholte, G. A. M. 1978a. Biosystematic studies in the collective species Stellaria media (L.) Vill. (I). Proc. Roy. Neth. Acad. Sci. 81: 442-456.

1978b. Biosystematic studies in the collective species Stellaria media (L.) Vill. (11). Proc. Roy. Neth. Acad. Sci. 81: 457-465.

Schoute, J. C. 1935. On the perianth aestivation in the Portulacaceae and the Basellaceae. Rec. Trav. Bot. Néerland. 32:395-405

Sell, P. D. 1963. Notes on the European species of Scleranthus. In: V. H. Heywood, (ed.) Flora Europaca Notul. System. No. 2. Repert. Spec. Nov. 68: 167-169.

, \& F. H. Whitehead. 1964. Notes on the annual species of Cerastium in Europe. Repert. Sp. Nov. 69: 14-24.

Scora, R. W., C. Grieve, W. A. Clerx, \& J. Kumamoto. 1989. Salt tolerance of Portulaca oleracea L. (Abstr.) Am. Jour. Bot. 76 (suppl. 6): 189.

Serbanescu-Jitariu, G. 1984. Recherches sur la morphologie du pollen el la taxonomie de certains representants de la famille Caryophyllaceac. Rev. Roum. Biol., Biol. Veg. 29: 13-23.

Seringe, N. C. 1824. Caryophylleac. In: A. P. de Candolle, Prodr. 1: 351-367, 385-422.

Sharitz, R. R., \& J. F. McCormick. 1973. Population dynamics of two competing annual species. Ecology 54: 723-740.

Sharma, H. P. 1954. Studies in the order Centrospermales. 1. Vascular anatomy of the flower of certain species of the Portulaceac. Jour. Ind. Bot. Soc. 33: 98-111.

Shildneck, P., \& A. G. Jones. 1986. Cerastium dubium (Caryophyllaceae) new for the eastern half of North America. Castanea 51: 49-55.

Shinners, L. H. 1962a. New names in Arenaria (Caryophyllaceac). Sida 1: 49-52 . 1962b. Siphonychia transferred to Paronychia (Caryophyllaceac). Sida 1: 101-103. .

1962c. Stellaria corei Shinners, nom. nov. Sida 1: 103-104.

1965. Holosteum umbellatum (Caryophyllaceae) in the United States: population explosion and fractionated suicide. Sida 2: 119-128. 2: $392-393$.

1966. Cerastium glutinosum Fries (Caryophyllaceae) in Mississippi: new to North America. Sida

1969. Petrorhagia prolifera (Dianthus prolifer, Tunica prolifera) (Caryophyllaceac) in Arkansas and Texas. Sida 3: $345-346$.

Shults, V. A. 1984. The genus Saponaria, s. str. (Caryophyllaceae) in the flora of the USSR. Bot. Zhur. 69: $1475-1482$.

1989. The genus Saponaria (Saponaria L. s.l.) in the Flora SSSR. Riga. 127 pp.

Shykoff, J., \& C. Galen. 1987. Differential pollination efficiency of sex morphs of Silene acaulis L.: is sexual selection maintaining females?. Am. Jour. Bot. 74: 658.

Simmler, G. Monographie der Gattung Saponaria. Denkschr. Akad. Wien Math. Naturw. 85: 433-509.

Sims, J. 1806. Claytonia virginica. Bot. Mag. 24: pl. 941.

Singh, S. K. 1979. Polyploid breeding in Portulaca grandiflora L. Cylologia 44: 167-174.

Sinha, R. P., \& F. H. Whitchead. 1965. Meiotic studies of British populations of Stellaria media (L.) Vill., S. neglecta Weihe and S. pallida (Dumort.) Pire. New Phytol. 64: 343-345.

Skvarla, J. J., \& J. W. Nowicke. 1976. Ultrastructure of pollen exine in Centrospermous families. Pl. Syst. Evol. 126: $55-78$. 
Sladkov, A. N. 1984. On palynomorphology of Centrospermae. III. Family Caryophyllaceae Juss., subfamily Paronychioideae Vierh. Biol. Nauki (Moscow) 12(252): 5-14.

. 1986. On palynomorphology of Centrospermae. IV. Family Caryophyllaceae Juss., subfamily Alsinoideae Vierh. Biol. Nauki (Moscow). 10(274): 5-18.

. 1987. On palynomorphology of Centrospermae. V. Family Caryophyllaceae, Juss., subfamily

Silenoideae A. Br. Biol. Nauki (Moscow). 2(278): 5-17.

Small, J. K. 1926. A new catchfly from the southeastern states. Torreya 26: 65-67.

. 1910. A mountain Anychiastrum. Torreya 10: 230-231.

Smith, G. L. 1966. Spergula morisonii in America. Rhodora 68: 520-521.

Sobey, D. G. 1981. Biological flora of the British Isles. No. 150. Stellaria media (L.) Vill. Jour. Ecol. 69: 311-335.

1987. Differences in seed production between Stellaria media populations from different habitat types. Ann. Bot. II 59: 543-549.

Sollner, R. 1953. Sur l'emploi des criteres cytologiques dans la taxinomie du genre Cerastium. Bull. Soc. Neuchatel. Sci. Nat. 76: 121-132.

1954. Recherches cytotaxinomiques sur le genre Cerastium. Ber. Schweiz. Bot. Ges. 64: 221-354.

Sommerfeld, W. 1933. Über Scleranthus annuus L. Unpubl. Ph.D. Dissertation, Friedrich-Wilhelms Universität, Berlin. 54 pp.

Souèges, R. 1924. Developpement de l'embryon chez le Sagina procumbens L. Bull. Soc. Bot. Fr. 71: 590-614. . 1938a. Embryogenie des Illecebracees. Development de l'embryon chez le Scleranthus perennis

L. Compt. Rend. Acad. Sci. (Paris) 206: 1404-1406.

. 1938b. Embryogéne des Portulacacées. Développement de l'embryon chez la Portulaca oleracea

L. Compt. Rend. Acad. Sci. (Paris) 207: 768-770.

- 1945. Embryogenie des Caryophyllacees. Developpement de l'embryon chez l'Arenaria

serpyllifolia. Compt. Rend. Acad. Paris 221: 320-322.

Sourkova, M. 1977. Taxonomic notes on Silene subg. Otites. Preslia 49: 9-12.

. 1978. Caryophyllaceae subfam. Dianthoideae -- Begrenzung, Charakteristik und Gliederung.

Preslia 50: 139-152.

Sprague, T. A. 1920. Stellaria or Alsine. Kew Bull. 1920: 308-318.

1927. Tunica. Mert. \& Koch. Jour. Bot. 65: 225-227.

Steiner, E. 1944. Cytological studies on Talinum and Portulaca. Bot. Gaz. 105: 374-379.

Sterk, A. A. 1968. Een studie van de variabiliteit van Spergularia media en Spergularia marina van Nederl.

Meded. Bot. Mus. Utrecht 284: 1-155.

. 1969a. Biosystematic studies of Spergularia media and $S$. marina in the Netherlands. I. The morphological variability of $S$. media. Acta Bot. Neerl. 18: 325-338.

. 1969b. Biosystematic studies of Spergularia media and S. marina in the Netherlands. II. The

morphological variation of $S$. marina. Acta Bot. Neerl. 18: 467-476.

. 1969c. Biosystematic studies of Spergularia media and $S$. marina in the Netherlands. III. The

variability of $S$. media and $S$. marina in relation to the environment. Acta Bot. Neerl. 18: 561-577.

. 1969d. Biosystematic studies of Spergularia media and S. marina in the Netherlands. IV.

Reproduction, dissemination, karyogenetics, and taxonomy. Acta Bot. Neerl. 18: 639-650.

19: 488-494.

. 1970. Reduction of the androecium in Spergularia marina (Caryophyllaceae). Acta Bot. Neerl.

, \& L. Dijkhuizen. 1972. The relation between the genetic determination and the ecological

significance of the seed wing in Spergularia media and S. marina. Acta Bot. Neerl. 21: 481-490.

Steyermark, J. A. 1941. A study of Arenaria patula. Rhodora 43: 325-333.

Stipe, M. S. 1939. Studies in the life history of Sabulina brevifolia (Nutt.) Small. M.S. Thesis, Emory Univ., Atlanta, Georgia (Unpubl.).

Stritch, R. H. 1982. A new color form of Dianthus armeria L. Castanea 47: 219-220.

Stroh, G. 1939. Die Gattung Gypsophila. Vorläufiger Katalog. Beih. Bot. Centr. B. 59: 455-477.

Svennson, L. 1985. An estimate of pollen carryover by ants in a natural population of Scleranthus perennis L.

(Caryophyllaceae). Oecologia 66: 373-377. 
- 1986. Secondary pollen carryover by ants in a natural population of Scleranthus perennis (Caryophyllaceae). Oecologia. 70: 631-632.

. 1988. Inbreeding, crossing and variation in stamen number in Scleranthus annuus (Caryophyll aceae), a selfing annual. Evol. Trends Plants 2: 31-38.

Svensson, R., \& M. Wigren. 1982. Competition, nutrient and herbicide experiments illustrating the decline of some weeds. Sv. Bot. Tidskr. 76: 241-258.

. 1983. History and biology of Agrostemma githago in Sweden. Sv. Bot. Tidskr. 77: 165-190.

Swanson, J. R. 1966. A synopsis of relationships in Montioideae (Portulacaceae). Brittonia 18: 229-241.

Sylven, N. 1931. Tvenne Svenska Cerastium-hybrider. Bot. Not. 1931: 161-173.

Szujko-Lacza, J, D. Kovats, \& M. Rajczy. 1979. Revision and numerical evaluation of the Hungarian Spergularia species (Caryophyllaceae). Ann. Hist. Nat. Mus. Natl. Hungarici 71: 73-99.

Talavera, S. 1979. Revision de la sect. Erectorefractae Chowdhuri del genero Silene L. Lagascalia 8: 135-164. . 1988. Nombres y combinaciones nuevas en genera Silene. Anal. Inst. Bot. Cavanilles 45: 361-362.

Terahara, N., M.-A. Yamaguchi, K. Takeda, J. B. Harborne, \& R. Self. 1986. Anthocyanins acylated with malic acid in Dianthus caryophyllus and D. deltoides. Phytochemistry 25: 1715-1717.

Terzijski, D. 1974. About some peculiarities of the embryogenic processes and the character of the embryony in Spergula arvensis L. Genet. Pl. Breeding 7: 322-330.

Thieret, J. W. 1966. Seeds of some United States Phytolaccaceae and Aizoaceae. Sida 2: 352-360.

Thomas, S. M. 1980. Population studies and delimitation of species in the genus Petrorhagia, (Section Kohlrauschia). Unpubl. Ph.D. Dissertation, Westfield College, Univ. of London. 281 pp.

. 1983a. A taxonomic clarification of Petrorhagia section Kohlrauschia (Caryophyllaceac). Jour. Linn. Soc. Bot. 87: 55-75.

1983b. Chromosome studies in species and hybrids of Petrorhagia sect. Kohlrauschia (Caryophyllaceae). Pl. Syst Evol. 141: 243-255.

, \& B. G. Murray. 1981. Breeding systems and hybridization in Petrorhagia sect. Kohlrauschia (Caryophyllaceae). Plant Syst. Evol. 139: 77-94.

Thompson, P. A. 1970. Germination of species of Caryophyllaceac in relation to their geographical distribution in Europe. Ann. Bot. 34: 427-449.

- 1973a. Effects of cultivation on the germination character of the Corn Cockle (Agrostemma githago L.). Ann. Bot. 37: 133-154.

. 1973b. The effects of geographical dispersal by man on the evolution of physiological races of the Corncockle (Agrostemma githago L.). Ann. Bot. 37: 413-421.

Thomson, B. F. 1942. Floral Morphology of the Caryophyllaceac. Am. Jour. Bot. 29: 333-349.

Trela-Sawicka, Z. 1966. Cytological investigations in the genus Scleranthus L. Acta Biol. Cracov. Ser. Bot. 9: 59-63. pl. 6.

Trivedi, S., \& R. S. Tripathi. 1982. The effects of soil texture and moisture on reproductive strategies of Spergula anensis L. and Plantago major L. Weed Res. 22: 41-49.

Tsarenko, O. N. 1987. Morphological peculiarities of Gypsophila L. s. l. (Caryophilaceae) seeds. Ukrain. Bot. Zurn. 44(4): 55-58.

Turkington, R., N. C. Kenkel, \& G. D. Franko. 1980. The biology of Canadian weeds. 42. Stellaria media (L.) Vill. Canad. Jour. Pl. Sci. 60: 981-992.

Turner, B. L. 1983. The Texas species of Paronychia (Caryophyllaceac). Phytologia 54: 9-23.

Tursunov, Z. 1972. Development of female gametophyte in Saponaria officinalis. Dokl. Akad. Nauk. Uzbek SSR. 3: $60-62$.

Tutin, T. G. 1963. New taxa and new names in European Dianthus. pp. 189-193. In: V. H. Heywood, (ed.) Notulae systematicae ad floram europaeam spectantes No. 2. Repert. Sp. Nov. 68: 163-210.

Ugborogho, R. E. 1973. North American Cerastium ariense L. I. Cytology. Cytologia 38: 559-566. . 1977. North America Cerastium arvense L.: taxonomy, reproductive system and evolution. Phyton (Buenos Aires) 35: 169-187.

1979. North American Cerastium ariense L.: a case of spontaneous mutation. Phyton Buenos Aires. 37: 73-80.

Ungar, I. A. 1987. Population ecology of halophyte seeds. Bot. Rev. 53: 301-334. 
Uphof, J. C. Th. 1968. Dictionary of Economic Plants. C. Cramer. 591 pp.

Uttal, L. J. 1964. A hybrid population of Claytonia in Virginia. Rhodora 66: 136-139.

Van Helsdingen, P. J., M. Duyndam-van den Berge, \& W. K. N. Karstens. 1968. Patterns of the leaf epidermis of Silene vulgaris (Moench) Garcke and Dianthus caryophyllus L. Proc. Roy. Neth. Acad. Sci. C 71: 537-549.

Verkleij, J. A. C., A. M. de Boer, \& T. F. Lugtenborg. 1980. On the ecogenetics of Stellaria media (L.) Vill. and Stellaria pallida (Dum.) Pire from abandonded arable land. Oecologia 46: 354-359.

Veselova, T. D. 1980. On the nature of the placenta of Caryophyllaceae. Vestn. Miosk. Univ. Biol. XVI. 1980(2): 44-48.

. 1981. Androccium development in bisexual and female flowers of Cerastium biebersteinii DC. Biol. Nauki (Moscow) 8(212): 61-66.

. 1982. Development of microsporangium and male gametophyte in Lychnis flos-cuculi L. Biol. Nauki (Moscow) 10(226): 67- 72.

. 1983a. To the embryology of the Caryophyllaceae Juss. Biol. Nauki (Moscow) 4(232): 59-70.

. 1983b. Development of ovule and seed in Cerastium biebersteinii DC. Biol. Nauki (Moscow) 5(233): $59-64$.

. 1984a. Embryological study of Spergularia rubra [L.] J. et C. Presl. 1. The development of microand macrosporangia, gametophytes, seed. Vestn. Mosk. Univ. Biol. XVI 1984(1): 33-39.

. 1984b. Embryological study of Spergularia rubra [L.] J. et C. Presl. 2. Embryogeny. Vestn. Mosk. Univ. Biol. 1984(2): 59-62.

Vierhapper, F. 1898. Zur Systematik und geographischen verbreitung einer alpinen Dianthus-grüppe. Akad. Wien. Sitz.-Ber. 107(1): 1057-1170. tab. 1-2, Karte 1.

409-417.

1901. Zur systematischen Stellung des Dianthus caesius Sm. Österr. Bot. Zeitschr. 51: 361-366,

1907. Die systematische Stellung der Gattung Scleranthus. Österr. Bot. Zeitschr. 62: 41-47,91-96.

Vignon, F. 1966. Embryogenie des Caryophyllacees. Developpement de l'embryon chez le Spergularia marginata Kittel. Compt. Rend. Acad. Paris 263: 505-508.

, \& A. Lebegue. 1965. Embryogenie des Caryophyllacees. Developpement de l'embryon chez le

Lychnis flos-cuculi L. Compt. Rend. Acad. Paris 260: 5613-5616.

- 1966. Embryogenie des Caryophyllacees. Developpement de l'embryon chez le Melandrium

rubrum Garcke. Compt. Rend. Acad. Paris 262: 2149-2152.

Vivian, V. E. 1942. Symmetry studies in Sagina. Bull. Torrey Bot. Club 69: 634-636.

Volponi, C. R. 1987. Palynological study of Argentine species of Arenaria L. and Stellaria L. Candollea 42: 545-551.

Voss, E. G. 1968. The spring beauties (Claytonia) in Michigan. Mich. Bot. 7: 77-93.

1972. Michigan Flora. Part 1. Gymnosperms and Monocots. Bull. Cranbrook Inst. Sci. 55, \&

Univ. Mich. herbarium. xv $+488 \mathrm{pp}$.

1985. Michigan Flora. Part 2. Dicots (Saururaceae - Cornaceae). Bull. Cranbrook Inst. Sci. 59,

\& Univ. Mich. herbarium. xix +724 pp.

Votocek, E., \& F. Valentin. 1932. Notices phytochimiques. I. Sur les glucides de la gomme de Viscaria vulgaris

(Lychnis viscaria L.). Coll. Trav. Chim. Tchecosl. 4: 282-284.

Wagner, H., G. Obermeier, O. Seligmann, \& V. Mohan Chari. 1979. NeueFlavon-C-0-glykoside aus Melandrium album. Phytochemistry 18: 907-910.

Wagner, L. K. 1986. Variation in seed-coat morph ratios in Spergula arvensis L. Bull. Torrey Bot. Club 113: 28-35.

1988. Germination and seedling emergence in Spergula arvensis. Am. Jour. Bot. 75: 465-475.

Wagstaff, S. J., \& R. J. Taylor. 1988. Genecology of Cerastium arvense and C. beeringianum (Caryophyllaceae)

in northwest Washington. Madroño 35: 266-277.

Wallace, R. S. 1987. Seed characters, biogeography and systematics of the genus Mollugo (Molluginaceae).

(Abst.) Am. Jour. Bot. 74: 763.

Ward, D. B. 1977a. Keys to the flora of Florida -- 2, Paronychia (Caryophyllaceac). Phytologia 35: 414-418. 
1977b. Corrections in Paronychia (Caryophyllaceac). Phytologia. 37: 449-450.

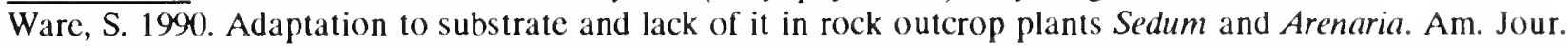
Bot. 77: 1095-1100.

Warming, E. 1921. The structure and biology of arctic flowering plants II. 13. Caryophyllaceac. Meddel. Grönland 37: 231-342.

Warmke, H. E. 1946. Sex determination and sex balance in Melandrium album. Am. Jour. Bot. 33: 648-660.

Warner, A., \& M. Zenkteler. 1973. The embryo sac development and fertilization in Dianthus amurensis Jeck. Bull. Soc. Amis Sci. Letters Poznan D. 14: 57-70.

Watkinson, A. R. 1981. Interference in pure and mixed populations of Agrostemma githago. Jour. Applied Ecol. 18: $967-976$.

Weatherby, C. A. 1924. A note on Stellaria pubera Michx. Rhodora 26: 169-171.

1924. A note on Stellaria pubera Michx. Rhodora 22: 15-16.

Weaver, R. E., Jr. 1970. The Arenarias of the southeastern granitic flat-rocks. Bull. Torrey Bot. Club 97: 40-52.

Weigand, K. M. 1920. A new species of Spergularia. Rhodora 26: 169-171.

Weller, S. G., A. K. Sakai, W. L. Wagner, \& D. R. Herbst. 1990. Evolution of dioecy in Schiedea (Caryophyllaceae: Alsinoideac) in the Hawaiian Islands: biogeographical and ccological factors. Syst. Bot. 15: 266276.

Wenger-Razine, M. 1970. Contribution a l'etude cytotaxonomique du genre Gypsophila L. Bull. Soc. Neuchatel. Sci. Nat. 93: 179-186.

Wenzel, G. E., J. D. Fontana, \& J. B. C. Correa. 1990. The viscous mucilage from the weed Portulaca oleracea L. 11 th Symposium on Biotech. for Fuels \& Chem. Colo. Spgs. CO (1989). Appl. Bioch. Biotech. 24-25: 341-354.

Wherry, E. T. 1928. The distribution of Silene wherryi Small. Torreya 28: 89-92.

Whitchead, F. H. 1955. Taxonomic studies in the genus Cerastium. I. C. atrovirens, C. pumilum, and C. semidecanarum. Watsonia 3: 213-227.

1956a. Preliminary investigation of factors determining the growth form of Cerastium tetrandrum Curt. Jour. Ecol. 44: 334-340.

1956b. Taxonomic studies in the genus Cerastium. II. Cerastium subtetrandrum (Lange) Murb. Watsonia. 3: 324-326.

, \& R. P. Sinha. 1967. Taxonomy and taximetrics of Stellaria media (L.) Vill., S. neglecta Weihe and S. pallida (Dumort.) Pire. New Phytol. 66: 769-784.

Williams, F. N. 1885. Enumeratio specierum varietatumque generis Dianthus; characteres communes sectionibus includens. Jour. Bot. 23: 340-349.

. 1889a. Revision of the specific forms of the genus Gypsophila. Jour. Bot. 27: 321-329.

$1889 \mathrm{~b}$. Notes on the pinks of western Europe. London. iv $+5-47 \mathrm{pp}$.

. 1890a. The carnation from a botanical point of view. Jour. Royal Hort. Soc. 12: 464-470.

1890b. Synopsis of the genus Tunica. Jour. Bot. 28: 193-199.

. 1890c. The Pinks of Central Europe. London. viii +66 pp.

1893a. A monograph of the genus Dianthus Linn. Jour. Linn. Soc. Bot. 29: 346-478.

. 1893b. The disintegration of Lychnis. Jour. Bot. 31: 167-170.

. 1894. Primary subdivisions in the genüs Silene. Jour. Bot. 32: 10-13.

1895. On the genus Arenaria Linn. Bull. Herb. Boiss. 3: 593-603.

1896. A revision of the genus Silene Linn. Jour. Linn. Soc. Bot. 32: 1-196.

. 1898a. A revision of the genus Arenaria, Linn. Jour. Linn. Soc. Bot. 33: 326-437.

. 1898b. On primary characters in Cerastium. Jour. Bot. 36: 8-10.

1898c. Enumeration provisoire des espéces du genre Cerastium. Bull. Herb. Boiss. 6: 893-904.

1898d. Critical notes on some species of Cerastium. Jour. Bot. 36: 341-344. (first of a series of

the same title published through 1923)

1907. A revision of Stellaria subg. Adenonema. Bull. Herb. Boiss. 11. 7: 830-836.

. 1918. Revision of the British species of Sagina. Rep. Bot. Soc., \& Exch. Club Britt. Isles. 5: 190-

204.

Willis, J. C. 1892. The distribution of the seed in Claytonia. Ann. Bot. 6: 382-383. 
Wofford, B. E. 1981. External seed morphology of Arenaria (Caryophyllaceae) of the southeastern United States. Syst. Bot. 6: 126-135.

, D. H. Webb, \& W. M. Dennis. 1977. State records and other recent noteworthy collections of Tennessee plants II. Castanea 42: 190-193.

Wohlpart, A., \& T. J. Mabry. 1968. The distribution and phylogenetic significance of betalains with respect to the Centrospermae. Taxon 17: 148-152.

Wolf, S. J., K. E. Denford, \& J. G. Packer. 1979. A study of the flavonoids of the Minuartia rossii complex. Canad. Jour. Bot. 57: 2374-2377.

, J. G. Packer, \& K. E. Denford. 1979. The taxonomy of Minuartia rossii (Caryophyllaceae). Canad. Jour. Bot. 57: 1673-1686.

Woodcock, E. F. 1926. Morphology of the seed in Claytonia virginica. Pap. Mich. Acad. Sci. 5: 195-200. 233-238.

1928. Observations on the morphology of the seed of Cerastium vulgatum. Pap. Mich. Acad. 8:

Wright, F. R. E. 1953. Note on the dispersal of Sagina nodosa var. moniliformis Lange. Watsonia 2: 369-370.

Wright, W. H. 1951. Weed Seeds. Sedges (Cyperaceae) Pink Family (Caryophyllaceae). Dept. Agric. Canada. King's Printer, Ottawa.

Wrigley, F. 1986. Taxonomy and chorology of Silene section Otites (Caryophyllaceae). Ann. Bot. Fenn. 23: 69-81.

Wu, C.Y. 1982. Taxa nova generis Silenes L. e flora Sichuanense et Yunnanense. Acta Bot. Yunnanica 4: 145-156.

Wyatt, R. Arenaria alabamensis: 1977. A new combination for a granite outcrop endemic from North Carolina and Alabama. Bull. Torrey Bot. Club 104: 243-244.

. 1984a. The evolution of self-pollination in granite outcrop species of Arenaria (Caryophyllaceae).

I. Morphological correlates. Evolution 38: 804-816.

1984b. The evolution of self-pollination in granite outcrop species of Arenaria (Caryophyllaceae).

III. Reproductive effort and pollen-ovule ratios. Syst. Bot. 9: 432-440.

. 1984c. The evolution of self-pollination in granite outcrop species of Arenaria (Caryophyllaceae).

IV. Correlated changes in the gynoecium. Am. Jour. Bot. 71: 1006- 1014.

. 1984d. Intraspecific variation in seed morphology of Arenaria uniflora (Caryophyllaceae). Syst.

Bot. 9: 423-431.

. 1986. Ecology and evolution of self-pollination in Arenaria uniflora (Caryophyllaceae). Jour.

Ecol. 74: 403-418.

1988. Phylogenetic aspects of the evolution of self-pollination. pp. 109-131 In: L. D. Gottlieb \& S. K. Jain, (eds.) Plant Evolutionary Biology. London.

. 1990. The evolution of self-pollination in granite outcrop species of Arenaria (Caryophyllaceae).

V. Artificial crosses within and between populations. Syst. Bot. 15: 363-369.

Wyse Jackson, M. B. 1992. Taxonomic notes on Cerastium fontanum Baum. emend Jalas (Caryophyllaceae) in Europe. pp. 325-328 In: Newton, A. M. (ed.). Flora Europaea: Notul. Syst. Fl. Eur. Sp. ser. 2, no. 5. Jour Linn. Soc. Bot. 109: 319-328.

373-382.

\& J. A. N. Parnell. 1987. A biometric study of the Arenaria ciliata L. complex. Watsonia 16:

Yukhananov, D. Kh., \& E. A. Krasnov. 1973. The distribution of triterpenic glycosides and flavonoids in Caryophyllaceae. Communication 1. Qualitative estimation of the presence of biologically active substances in plants of the family Caryophyllaceae. Rastitel'nye Resursy 9: 540-547.

, \& L. A. Sapunova. 1976. The presence of triterpenic saponin-gypsoside in the representatives of Caryophyllaceae. Rastitel'nye Resursy 12: 244-247.

, I. N. Sokolsky, E. P. Zinkevich, \& V. B. Kuvayev. 1971. The investigation of plants of the family

Caryophyllaceae for the content of triterpenic saponin - gypsoside. Rastitel'nye Resursy 7: 386-390.

A. I. Yatzyno, A. D. Turova, \& V. B. Kyvayev. 1972. The content of saponins in the representatives of Caryophyllaceae and their haemolithic activity. Rastitel'nye Resursy 8: 374-377.

Zandonella, P. 1966a. Les nectaires des Caryophyllaceae: presence d'un systeme de drainage dans la tribu des

Lychnideae. Compt. Rend. Acad. Paris D 262: 2035-2038 
1966b. Les nectaires des Caryophyllaceae. Drainage du tissu glandulaire dans la tribu des Diantheac. Compt Rend. 263: 109-111. $2466-2469$.

1967. Les nectaires des Alsinoideac: Stellaria et Cerastium, sensu lato. Compt. Rend. 264:

1970. Le nectaire floral des Caryophyllaceac: L'appareil nectarifere des Sperguleac. Bull. Linn. Soc. (Lyon) 39: 253-260.

Zemtsova, G. N., \& S. F. Dzhumyrko. 1976. Flavone glycosides in Silene species. Farmatsija (3): 26-29.

Zenkteler, M. 1969. Test-tube fertilization and development of hybrids between some species of the Caryophyllaceae family. Poznanskie Towarzystwo Przyjaciol Nauk Biol. 33(2); 1-72.

Zhao, Y. Z. 1985. The study of phytotaxonomy of the genus Stellaria in Inner Mongolia. Bull. Bot. Res. North-East. Forest. Inst. 5(4): 139-150.

Zhukova, P. G. 1967. Karyology of some plants, cultivated in the Arctic-Alpine Botanical Garden. pp. 139-149. In: N. A. Avrorin (ed.), Plantarum in Zonam Polarem Transportatio. II. Leningrad.

Zinger, H.B. 1909. On the species of Camelina and Spergula occurring as weeds in sowings of flax and their origin. Trudy Bot. Muz. Akad. Nauk USSR 6: 1-303.

Zuev, V. V. 1990. Section Graminifoliae Chowdhuri, belonging to Silene L., genus (Caryophyllaceae) in Siberia. Bull. Mosk. Obshch. Isp. Pri. Biol. 95(1): 98-101. 
Note: Boldface indicates a name used in this treatment for plants that have been reliably reported to occur in the wild in New York State.

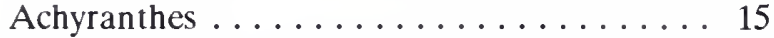

dichotoma .................. 15

Agrostemma ...............665

coronaria .................. 76

githago ................ 65

gracilis . . . . . . . . . . . . . 66

Alsine . . 17, 18, 27, 31, 46, 48, 49, 50, 51, 55, 56

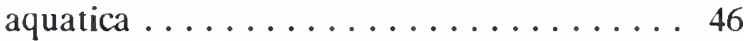

borealis ................... 53

graminea ................. 54

holostea ............... 48

longifolia ................. . 55

longipes ................. 56

marginata $\ldots \ldots \ldots \ldots \ldots \ldots \ldots \ldots$

maritima ................ 18

media ................. 51

michauxii ................ 31

pallida ................. 51

procumbens ................. 27

pubera ................... 49

tennesseensis ............. 50

uliginosa .................. 50

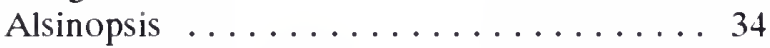

Ammodenia .................... 24

Anychia . . . . . . . . . . . . . . 14

canadensis ................ 14

dichotoma .................. 14

divaricata................. 13

polygonoides ............... 13

Arenaria ................. 45

angustifolia .............. 43

canadensis ................. 20

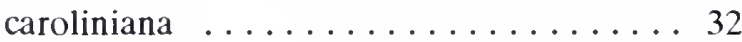

glabra ................................. 34

groenlandica ............... 33

lateriflora ................44 43

leptoclados ............. 45

macra ................. 31

marginata .............. 17

maritima ............... 17

media .................. 17

michauxii ................... 31

peploides ............................... 24

rubra ............................ 18

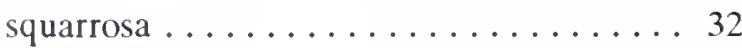

serpyllifolia ................ 45

stricta .................. 31
Behen .................. 84

Bigelowia . . . . . . . . . . . . . . . 53

Buda ............ 16, 17, 18, 20

borealis ................. 20

marina .................... 18

media ................ 17

rubra ................. 16

Caryophyllaceae ............... 10

Caryophyllum ............... 10

Cerastium ................ 35

apetalum ................ 38

aquaticum ............... 46

arvense ..................440

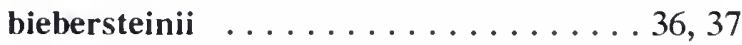

caespitosum . . . . . . . . . . . . 42

campestre .............. 46

columnae ................. 37

fontanum .............. 42

glomeratum .................. 38

glutinosum ................... 39

nutans . . . . . . . . . . . . . . . . 39

occidentale ................440

pennsylvanicum ............. 40

pubescens ................ 40

pumilum ................ 42

semidecandrum .............41

tenellum .................. . 39

tenuifolium ............... 40

tomentosum ............... 37

velutinum .............. 40

villosum ................. 40

viscosum ................ 38

vulgatum .............. 41

Claytonia ................... 4

caroliniana ............... 7

latifolia ................ 7

media ................ 5

multicaulis ...............5 5

robusta ................ 5

simsii ................ 5

virginica $\ldots \ldots \ldots \ldots \ldots \ldots \ldots \ldots$

Coronaria ................... . 74

Cucubalus ............... 79, 84

behen .................. 84

inflatus .................. 84

stellatus .................. 79

Dianthus ................ 58 
armeria ......................61

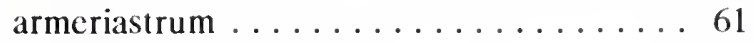

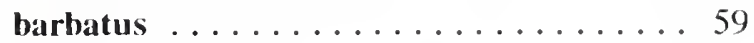

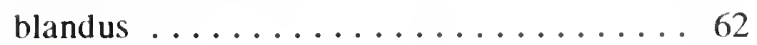

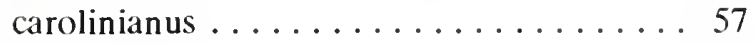

caryophyllus ................... 58

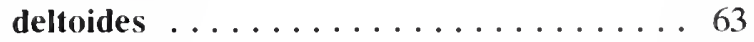

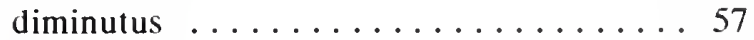

epirotus ..................... 61

hoppei ...................... 62

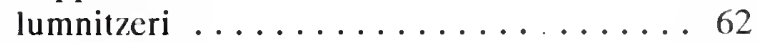

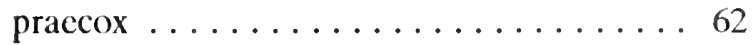

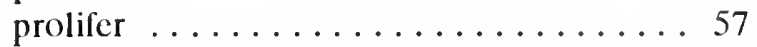

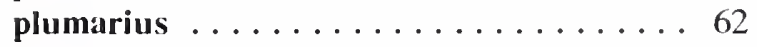

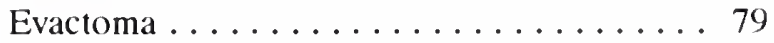

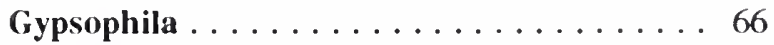

arrostii ....................... 69

bicolor ................... . . 69

carminca ................. 67

elegans .................... 67

grandiflora ................... 67

muralis ................... 68

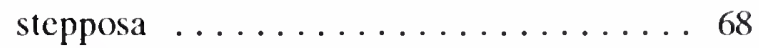

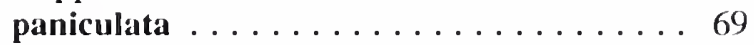

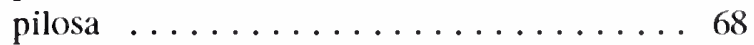

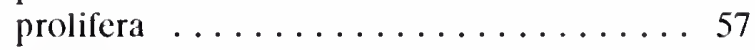

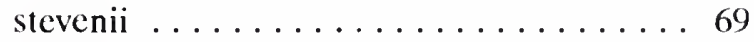

Holosteum ...................... 25

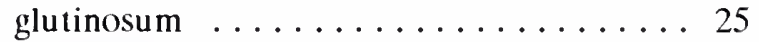

umbellatum .................... 25

Honckenya ................... 23

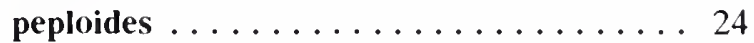

Kohlrauschia ................ 57

Lepigonum ............... 16, 17, 18

caninum $\ldots \ldots \ldots \ldots \ldots \ldots \ldots$

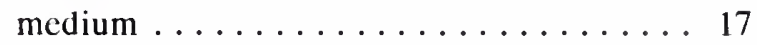

rubrum ................. 16

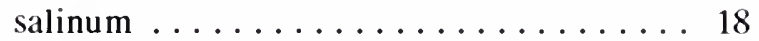

Lychnis .................... 73

alba ................... 89

arvensis ..................... 89

chalcedonica ............... 75

coronaria ................. 76

dioica ....................... 91

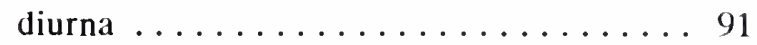

flos-cuculi ................... 74

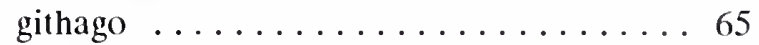

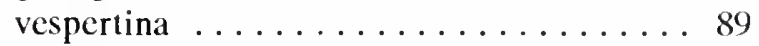

viscaria ................. 77

Malachium ................... 46

Melandrium ............ 85, 88, 89, 91

album ................... 89

dioicum ...................... 91 noctiflorum ................... 88

pennsylvanicum ................. 85

rubrum ......................... 91

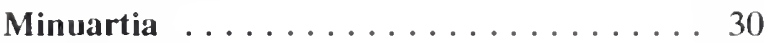

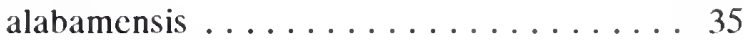

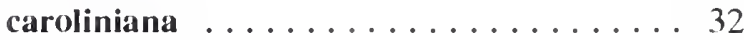

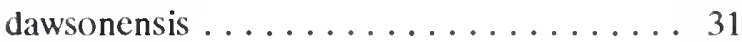

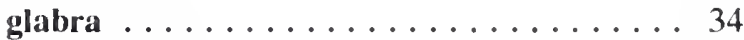

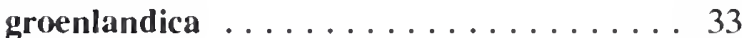

michauxii ..................... 31

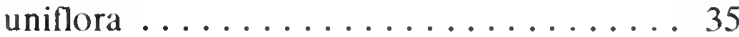

Moehringia ................... 43

lateriflora .................... 43

macrophylla ................ 43

Molluginaceae ................ 8

Mollugo .................... 8

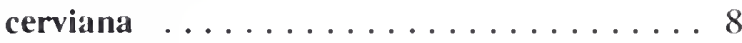

verticillata ........................ 9

Myosoton ..................... 46

aquaticum ..................... 46

Paronychia ..................... 12

canadensis ...................... 14

dichotoma ....................... 14

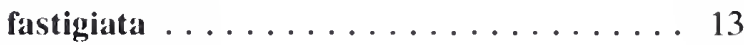

Portulaca ...................... 2

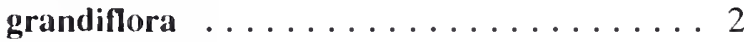

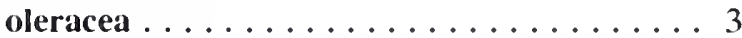

Portulacaceae ................. 1

Petrorhagia ..................... 57

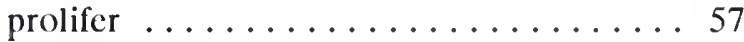

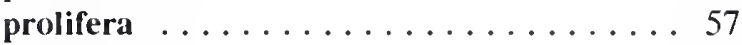

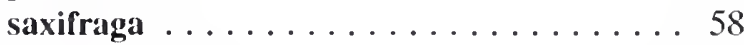

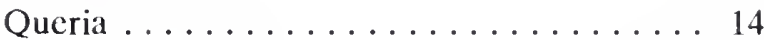

Sabulina ............... 31, 33, 34

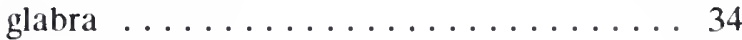

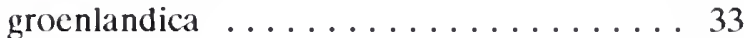

stricta .......................... 31

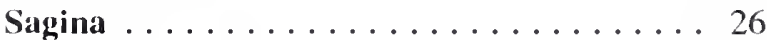

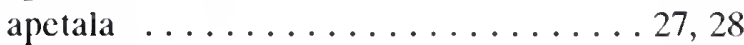

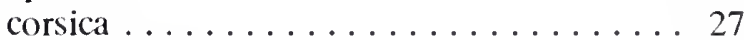

decumbens $\ldots \ldots \ldots \ldots . \ldots . \ldots 28$

echinosperma ................ 29

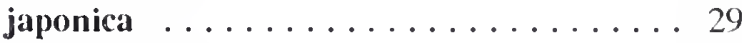

$\operatorname{muscosa} \ldots \ldots \ldots \ldots \ldots . \ldots . \ldots . . . \ldots 27$

procumbens ................... 27

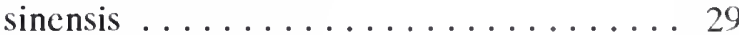

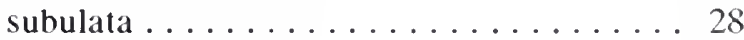

taquetii ...................... 29

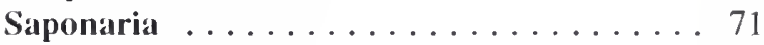

hispanica ................... 70

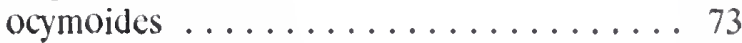

officinalis .................. 71

vaccaria ..................... 70 
Scleranthus ................. 22

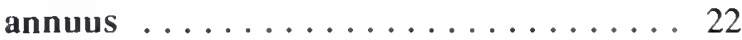

perennis ................... 22

uncinatus ................... 22

Silene .................. 77

alba .................... 89

anglica ................ . 87

antirrhina ............... 81

armeria ................. 80

caroliniana .............. . 85

cserii ................... 83

cucubalus ................... 84

dichotoma ................. 87

dioica ................... 91

divaricata ................. 81

fabaria ................ 83

gallica .................. . 87

glauca ................... 87

inflata .................. 84

latifolia Poir. . . . . . . . . . . . . . . . . 89

latifolia (Mill.) B.\& R. . . . . . . . . . 84 (89)

lituanica ................... 80

noctiflora .................. 88

pensylvanica $\ldots \ldots \ldots \ldots \ldots \ldots \ldots \ldots . \ldots \ldots$

pratensis . . . . . . . . . . . . 89

scabrella .................. . 79

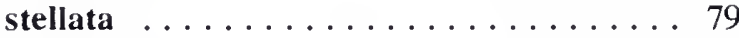

venosa .................. 84

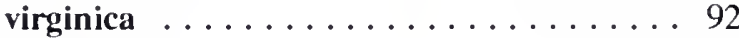

vulgaris . . . . . . . . . . . . . 84

wherryi ............... 85

Spergula ................ 21

arvensis .................. 21

canadensis .................. 20

decumbens ................... 28

marina ................... 18

salina ................ 18

pentandra ................. 21

Spergularia $\ldots \ldots \ldots \ldots \ldots \ldots \ldots \ldots \ldots$

alata ................... 17 campestris ................. 18

canadensis . . . . . . . . . . . . 20

canina ..................... 18

marginata ............... 17

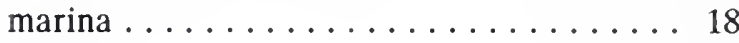

media ............... 17

rubra ................... 16

salina ................. 18

tangerina .................. 19

tenue ................... 18

Stellaria .................. 47

alsine ................. 50

apetala $\ldots \ldots \ldots \ldots \ldots \ldots \ldots \ldots \ldots \ldots$

aquatica $\ldots \ldots \ldots \ldots \ldots \ldots \ldots \ldots \ldots$

borealis ................. 53

calycantha ............... 53

corei .............. 49,50

crassifolia ............... 56

graminea ............... 54

graminifolia ............... 54

groenlandica ............... 33

holostea . . . . . . . . . . . . . . . . . 48

longifolia ............... 55

longipes $\ldots \ldots \ldots \ldots \ldots \ldots \ldots \ldots \ldots$

media .................... 51

montana ............... 54

neglecta ................. 51

pubera .................... 49

sylvatica ................... 50

uliginosa . . . . . . . . . . . . 50

Tissa ............... 16, 18, 20

canadensis ................ 20

marina ................... 18

rubra .................... 16

Tunica ..................... 57

Vaccaria ................ 70

hispanica ............... 70

segetalis .............. 70

vaccaria ................. 70

vulgaris $\ldots \ldots \ldots \ldots \ldots \ldots \ldots$

ISSN--0278-3355

ISBN---1-55557-228-6

3-019842 


QL 102 Aew York Botanical Garden Library 1951993 gen

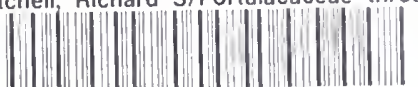

35185001734811 
